\title{
Hydraulic Analysis of the Pickwick Lock Culvert Valves
}

Allen Hammack, David S. Smith, Marshall Thomas, Jane M. Vaughan, and Morgan M. Johnston

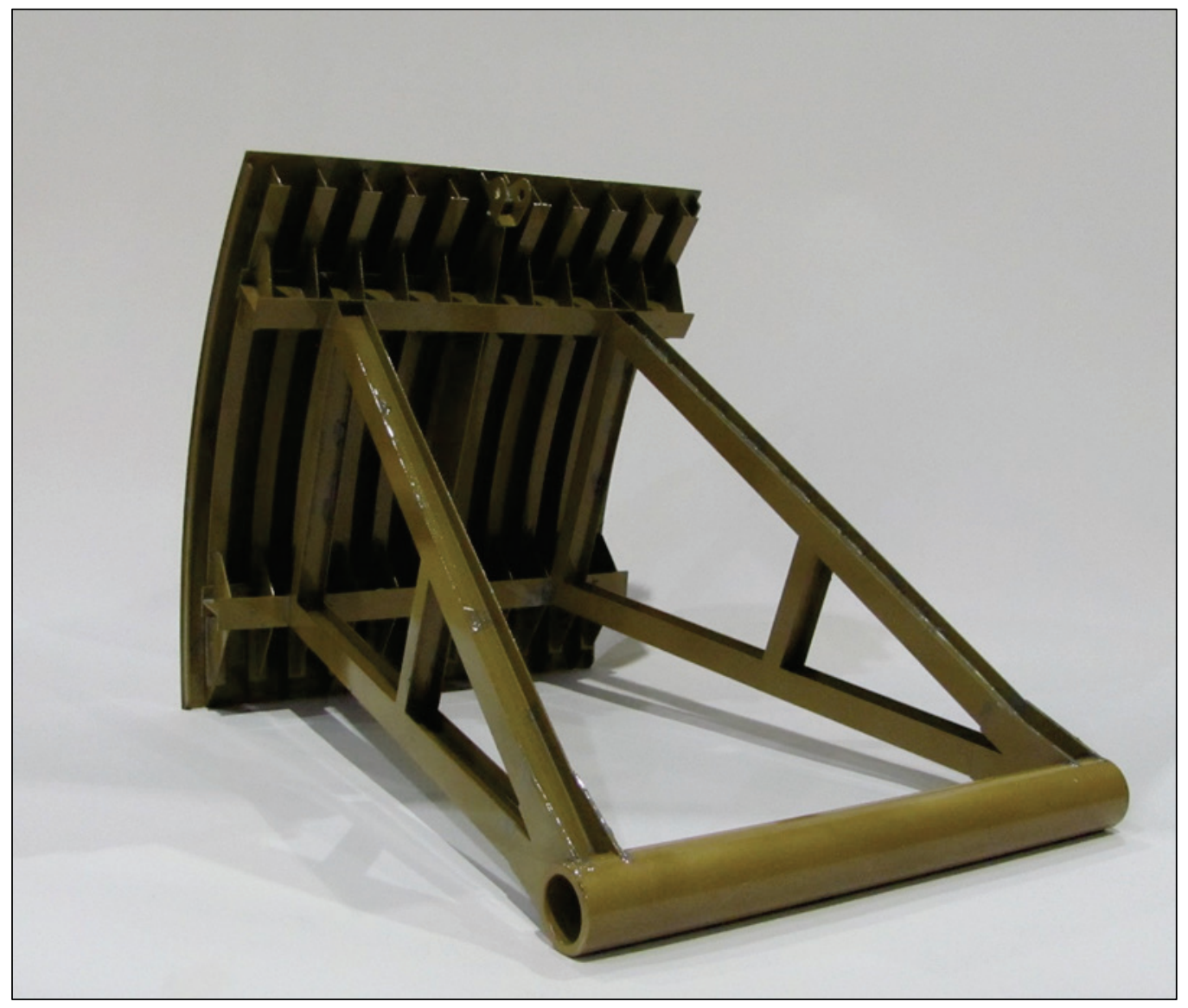


The U.S. Army Engineer Research and Development Center (ERDC) solves the nation's toughest engineering and environmental challenges. ERDC develops innovative solutions in civil and military engineering, geospatial sciences, water resources, and environmental sciences for the Army, the Department of Defense, civilian agencies, and our nation's public good. Find out more at www.erdc.usace.army.mil.

To search for other technical reports published by ERDC, visit the ERDC online library at http://acwc.sdp.sirsi.net/client/default. 


\title{
Hydraulic Analysis of the Pickwick Lock Culvert Valves
}

\author{
Allen Hammack, David S. Smith, Marshall Thomas, Jane M. Vaughan, \\ and Morgan M. Johnston \\ Coastal and Hydraulics Laboratory \\ U.S. Army Engineer Research and Development Center \\ 3909 Halls Ferry Road \\ Vicksburg, MS 39180-6199
}

Final report

Approved for public release; distribution is unlimited.

\author{
Prepared for U.S. Army Corps of Engineers, Nashville District \\ 801 Broadway A415 \\ Nashville, TN 37203 \\ Under Project 448755, “LRN Pickwick Lock”
}




\section{Abstract}

The reverse tainter valves at Pickwick Lock on the Tennessee River are being replaced. The original valves have experienced excessive repairs during their service life, so a new valve design is sought. A hydraulic physical model study has been conducted to collect flow and load information on the existing lock culvert valve and a proposed valve design. The proposed valve geometry is based on experience gained from other model and prototype studies of lock culvert valves. The loads on the trunnion, the axial load on the strut connecting the valve lift mechanism to the valve, and pressures along the culvert have been measured for both the existing and proposed valve designs. Using the information gleaned from all test results, a final valve design recommendation is provided.

DISCLAIMER: The contents of this report are not to be used for advertising, publication, or promotional purposes. Citation of trade names does not constitute an official endorsement or approval of the use of such commercial products. All product names and trademarks cited are the property of their respective owners. The findings of this report are not to be construed as an official Department of the Army position unless so designated by other authorized documents. 


\section{Contents}

Abstract....................................................................................................................................... if

Figures and Tables....................................................................................................................................

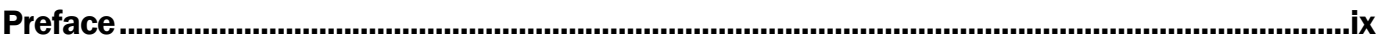

Unit Conversion Factors....................................................................................................................

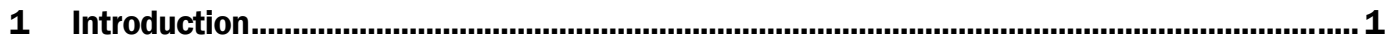

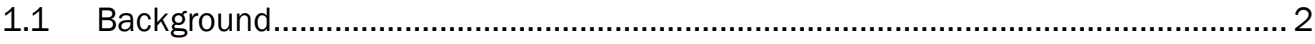

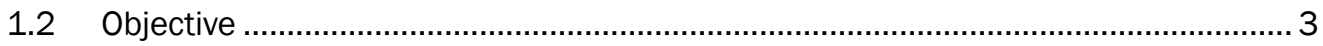

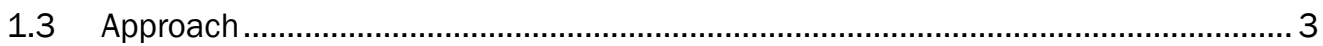

2 Relevant Physics.................................................................................................................... 4

2.1 Flow behavior near reverse tainter valves ........................................................... 4

2.2 Forces acting on reverse tainter valves.............................................................. 6

2.3 Similitude considerations ......................................................................... 11

2.3.1 Dynamic similitude......................................................................................... 12

2.3.2 Kinematic similitude .................................................................................... 12

2.3.3 Pickwick Lock culvert valve model scale correlations ......................................... 13

3 Model Description and Modeling Process ........................................................................14

3.1 Model description............................................................................................. 16

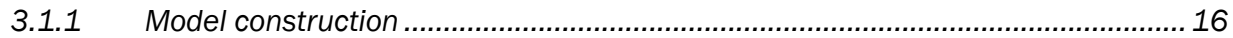

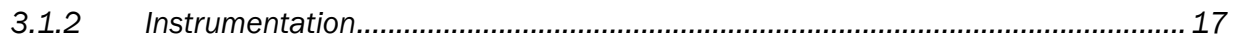

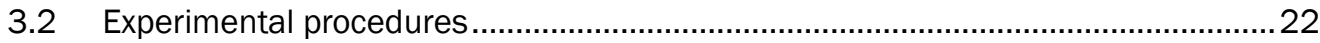

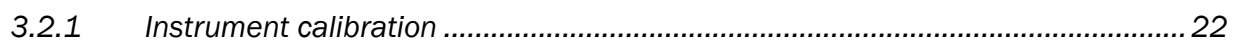

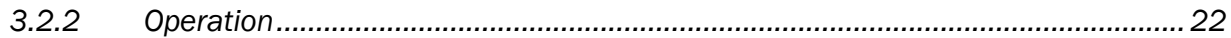

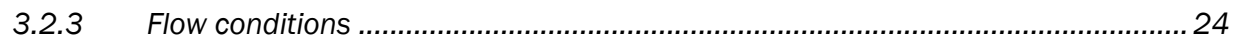

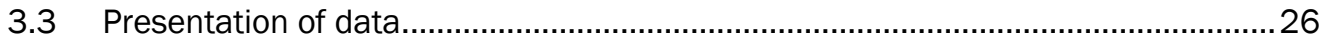

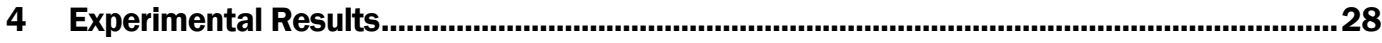

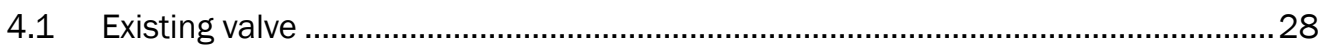

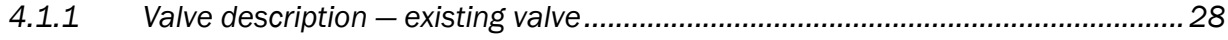

4.1.2 Flow behavior - existing design .................................................................. 30

4.1.3 Load results - existing valve ........................................................................... 32

4.2 Modified valve ................................................................................................ 43

4.2.1 Valve description - modified valve ................................................................... 43

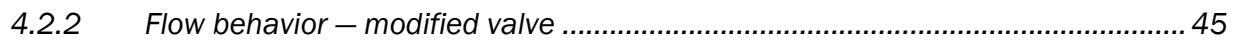

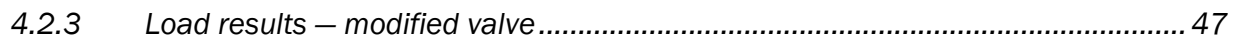

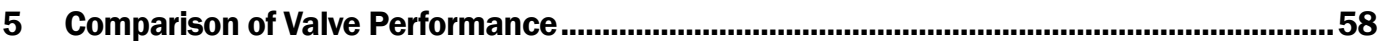

5.1 Valve performance - flow behavior.................................................................. 58

5.2 Valve performance - load magnitudes................................................................58

5.3 Valve performance - load variation ..................................................................... 60 


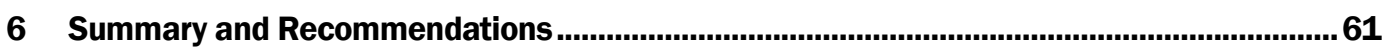

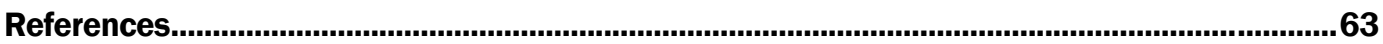

Appendix A: Existing Valve Load Result Plots ....................................................................64

Appendix B: Modified Valve Load Result Plots...............................................................................76

Appendix C: Valve Load Variation Plots...................................................................................88

Report Documentation Page 


\section{Figures and Tables}

\section{Figures}

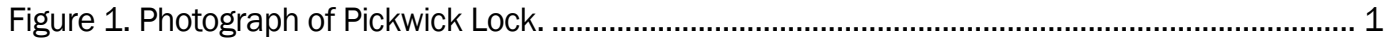

Figure 2. Pickwick Lock location.................................................................................................... 1

Figure 3. Crack found in gusseted plate on valve, September 2016................................................ 2

Figure 4. Typical reverse tainter valve components. ........................................................................... 4

Figure 5. Typical installation of a reverse tainter valve.................................................................... 5

Figure 6. Typical flow patterns around a reverse tainter valve.............................................................. 5

Figure 7. Schematic of valve opening dimensions................................................................... 6

Figure 8. Free-body diagram of a reverse tainter valve subjected to flow.......................................... 8

Figure 9. Valve moment balance geometry............................................................................. 11

Figure 10. Pickwick Lock culvert valve model schematic. ................................................................ 14

Figure 11. Pickwick Lock culvert valve model schematic - valve lift mechanism details................ 15

Figure 12. Pickwick Lock culvert valve physical model. ................................................................ 15

Figure 13. Pickwick Lock culvert valve physical model - valve close-up. .......................................... 16

Figure 14. Piezometer display board......................................................................................... 18

Figure 15. Piezometer layout. ............................................................................................ 19

Figure 16. Hoist load (force in long strut) measurement instrument............................................2 20

Figure 17. Load cell (hoist load measurement device) - installed..................................................2

Figure 18. Trunnion load measurement instrument................................................................... 21

Figure 19. Valve and load arm (trunnion load measurement device) - installed. ........................... 21

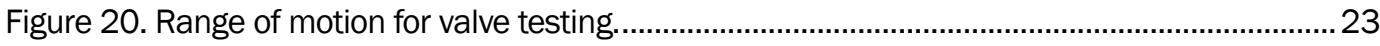

Figure 21. Pickwick Lock filling hydrograph, $51 \mathrm{ft}$ and $59 \mathrm{ft}$ lifts..................................................2

Figure 22. Pickwick discharge curves for physical model experiments $-59 \mathrm{ft}$ and $51 \mathrm{ft}$

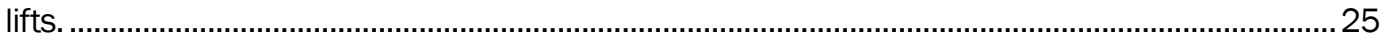

Figure 23. Existing Pickwick Lock culvert valve geometry - 4-view................................................ 29

Figure 24. Model valve - existing design.........................................................................................29

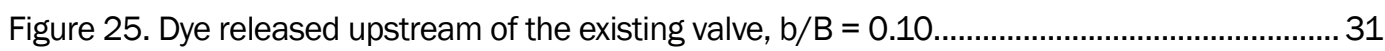

Figure 26. Existing valve at $\mathrm{b} / \mathrm{B}=0.20$ - downstream bulkhead slot flow. ................................... 31

Figure 27. Existing valve at $\mathrm{b} / \mathrm{B}=0.60$ - downstream bulkhead slot flow......................................32

Figure 28. Existing valve resultant hydraulic force line of action $-51 \mathrm{ft}$ lift......................................39

Figure 29. Existing valve resultant hydraulic force line of action $-59 \mathrm{ft}$ lift. .....................................40

Figure 30. Modified Pickwick Lock culvert valve geometry - 4-view.............................................. 43

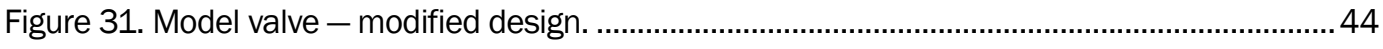

Figure 32. Differences in existing and modified Pickwick Lock culvert valve designs...................... 45

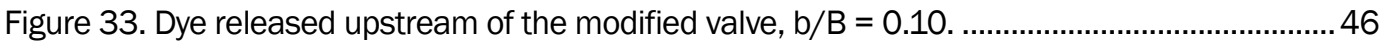

Figure 34. Modified valve at $\mathrm{b} / \mathrm{B}=0.35$ - downstream bulkhead slot flow. ................................ 47

Figure 35 Modified valve at $\mathrm{b} / \mathrm{B}=0.60$ - downstream bulkhead slot flow. .................................... 47

Figure 36. Modified valve resultant hydraulic force line of action $-51 \mathrm{ft}$ lift..................................54 
Figure 37. Modified valve resultant hydraulic force line of action - $59 \mathrm{ft}$ lift..................................55

Figure 38. Existing valve hoist load - $51 \mathrm{ft}$ lift. ........................................................................ 64

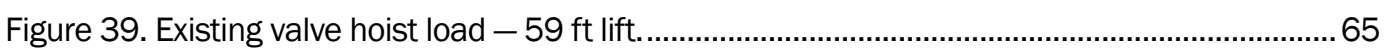

Figure 40. Existing valve vertical trunnion load $-51 \mathrm{ft}$ lift. ...........................................................6

Figure 41. Existing valve vertical trunnion load - $59 \mathrm{ft}$ lift...........................................................6

Figure 42. Existing valve longitudinal trunnion load $-51 \mathrm{ft}$ lift....................................................6

Figure 43. Existing valve longitudinal trunnion load $-59 \mathrm{ft}$ lift.....................................................6

Figure 44. Existing valve resultant trunnion load $-51 \mathrm{ft}$ lift....................................................67

Figure 45. Existing valve resultant trunnion load $-59 \mathrm{ft}$ lift. .........................................................6

Figure 46. Existing valve vertical trunnion end load $-51 \mathrm{ft} \mathrm{lift......................................................68}$

Figure 47. Existing valve vertical trunnion end load $-59 \mathrm{ft}$ lift. .....................................................69

Figure 48. Existing valve longitudinal trunnion end load $-51 \mathrm{ft}$ lift. ...............................................69

Figure 49. Existing valve longitudinal trunnion end load - $59 \mathrm{ft}$ lift. .............................................. 70

Figure 50. Existing valve resultant trunnion end load $-51 \mathrm{ft}$ lift. ..................................................... 70

Figure 51. Existing valve resultant trunnion end load $-59 \mathrm{ft}$ lift.................................................. 71

Figure 52. Existing valve vertical hydraulic load $-51 \mathrm{ft}$ lift............................................................. 71

Figure 53. Existing valve vertical hydraulic load $-59 \mathrm{ft}$ lift........................................................ 72

Figure 54. Existing valve longitudinal hydraulic load $-51 \mathrm{ft}$ lift.................................................. 72

Figure 55. Existing valve longitudinal hydraulic load $-59 \mathrm{ft}$ lift................................................... 73

Figure 56. Existing valve resultant hydraulic load $-51 \mathrm{ft}$ lift..................................................... 73

Figure 57. Existing valve resultant hydraulic load $-59 \mathrm{ft}$ lift......................................................74

Figure 58. Pressure head distribution along culvert, existing valve, $51 \mathrm{ft} \mathrm{lift.} \mathrm{................................74}$

Figure 59. Pressure head distribution along culvert, existing valve, $59 \mathrm{ft}$ lift.................................75

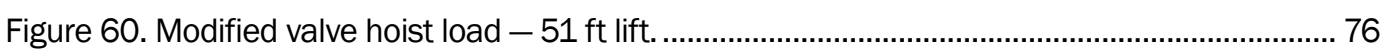

Figure 61. Modified valve hoist load - $59 \mathrm{ft}$ lift. ..................................................................... 77

Figure 62. Modified valve vertical trunnion load $-51 \mathrm{ft}$ lift.......................................................... 77

Figure 63. Modified valve vertical trunnion load $-59 \mathrm{ft}$ lift. ......................................................... 78

Figure 64. Modified valve longitudinal trunnion load $-51 \mathrm{ft}$ lift. ...................................................... 78

Figure 65. Modified valve longitudinal trunnion load $-59 \mathrm{ft}$ lift.....................................................79

Figure 66. Modified valve resultant trunnion load $-51 \mathrm{ft}$ lift............................................................79

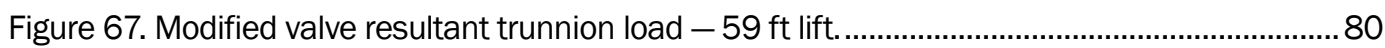

Figure 68. Modified valve vertical trunnion end load $-51 \mathrm{ft}$ lift. ..................................................... 80

Figure 69. Modified valve vertical trunnion end load $-59 \mathrm{ft}$ lift................................................... 81

Figure 70. Modified valve longitudinal trunnion end load $-51 \mathrm{ft}$ lift. ........................................... 81

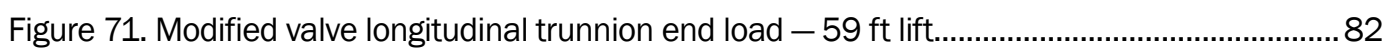

Figure 72. Modified valve resultant trunnion end load $-51 \mathrm{ft}$ lift................................................... 82

Figure 73. Modified valve resultant trunnion end load $-59 \mathrm{ft}$ lift...................................................

Figure 74. Modified valve vertical hydraulic load $-51 \mathrm{ft}$ lift.......................................................83

Figure 75. Modified valve longitudinal hydraulic load $-59 \mathrm{ft} \mathrm{lift...................................................} 84$

Figure 76. Modified valve longitudinal hydraulic load $-51 \mathrm{ft}$ lift. .............................................. 84 
Figure 77. Modified valve longitudinal hydraulic load $-59 \mathrm{ft}$ lift. ................................................ 85

Figure 78. Modified valve resultant hydraulic load $-51 \mathrm{ft}$ lift..................................................... 85

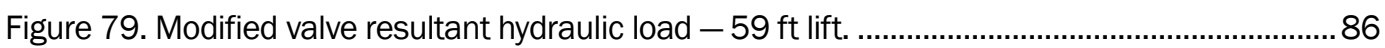

Figure 80. Pressure head distribution along culvert, modified valve, $51 \mathrm{ft}$ lift ..............................86

Figure 81. Pressure head distribution along culvert, modified valve, $59 \mathrm{ft}$ lift. ..............................8 87

Figure 82. Hoist load variation between valves $-51 \mathrm{ft}$ lift. .......................................................... 88

Figure 83. Hoist load variation between valves $-59 \mathrm{ft}$ lift............................................................ 89

Figure 84. Vertical trunnion load variation between valves $-51 \mathrm{ft}$ lift........................................... 89

Figure 85. Vertical trunnion load variation between valves $-59 \mathrm{ft}$ lift............................................90

Figure 86. Longitudinal trunnion load variation between valves $-51 \mathrm{ft} \mathrm{lift.} \mathrm{...................................90}$

Figure 87. Longitudinal trunnion load variation between valves $-59 \mathrm{ft}$ lift.................................... 91

Figure 88. Resultant trunnion load variation between valves $-51 \mathrm{ft}$ lift. ........................................ 91

Figure 89. Resultant trunnion load variation between valves $-59 \mathrm{ft}$ lift........................................92

Figure 90. Vertical trunnion end load variation between valves $-51 \mathrm{ft}$ lift. .....................................92

Figure 91. Vertical trunnion end load variation between valves $-59 \mathrm{ft}$ lift. ..................................93

Figure 92. Longitudinal trunnion end load variation between valves $-51 \mathrm{ft}$ lift..............................93

Figure 93. Longitudinal trunnion end load variation between valves $-59 \mathrm{ft}$ lift.............................94

Figure 94. Resultant trunnion end load variation between valves $-59 \mathrm{ft}$ lift. ...............................94

Figure 95. Resultant trunnion end load variation between valves - $59 \mathrm{ft}$ lift. ................................95

Figure 96. Vertical hydraulic load variation between valves $-51 \mathrm{ft}$ lift............................................95

Figure 97. Vertical hydraulic load variation between valves $-59 \mathrm{ft}$ lift. ..........................................96

Figure 98. Longitudinal hydraulic load variation between valves $-51 \mathrm{ft}$ lift...................................96

Figure 99. Longitudinal hydraulic load variation between valves $-59 \mathrm{ft}$ lift. ................................. 97

Figure 100. Resultant hydraulic load variation between valves $-51 \mathrm{ft}$ lift.................................97

Figure 101. Resultant hydraulic load variation between valves $-59 \mathrm{ft}$ lift......................................98

\section{Tables}

Table 1. Scale correlations for the Pickwick Lock culvert valve study.............................................13

Table 2. Piezometer and pressure cell locations............................................................................ 19

Table 3. Pickwick Culvert discharges in cubic feet per second (cfs) for each valve position,

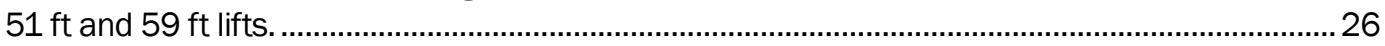

Table 4. Existing valve hoist loads, $51 \mathrm{ft}$ and $59 \mathrm{ft}$ lifts. .............................................................. 33

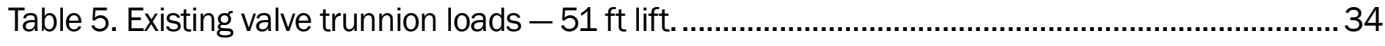

Table 6. Existing valve trunnion loads - $59 \mathrm{ft}$ lift........................................................................ 34

Table 7. Existing valve trunnion end loads - $51 \mathrm{ft}$ lift.....................................................................35

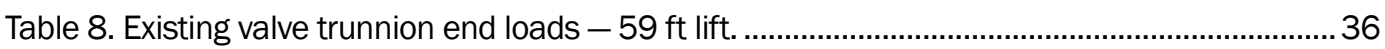

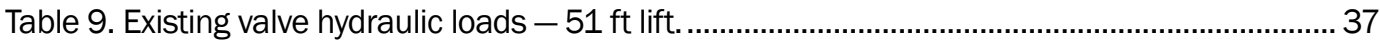

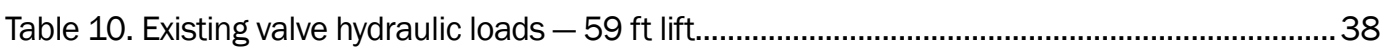

Table 11. Existing valve hydraulic force line of action values, both lifts...........................................38

Table 12. Existing valve pressure head in feet of prototype elevation- $51 \mathrm{ft} \mathrm{lift.............................} 41$ 
Table 13. Existing valve pressure head in feet of prototype elevation $-59 \mathrm{ft}$ lift............................ 42

Table 14. Modified valve hoist loads, 51- and $59 \mathrm{ft}$ lifts. ................................................................ 48

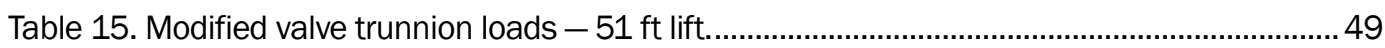

Table 16. Modified valve trunnion loads - $59 \mathrm{ft}$ lift......................................................................50

Table 17. Modified valve trunnion end loads - $51 \mathrm{ft}$ Lift.................................................................... 51

Table 18. Modified valve trunnion end loads - $59 \mathrm{ft}$ Lift............................................................... 51

Table 19. Modified valve hydraulic loads - $51 \mathrm{ft}$ lift......................................................................5

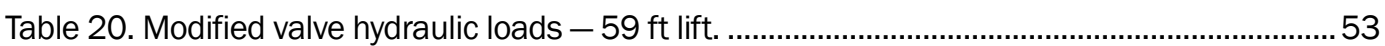

Table 21. Modified valve hydraulic force line of action values, both lifts..........................................53

Table 22. Modified valve pressures in feet of prototype elevation $-51 \mathrm{ft}$ lift................................56

Table 23. Modified valve pressures in feet of prototype elevation - $59 \mathrm{ft}$ lift.................................. 57 


\section{Preface}

The investigation reported herein was sponsored by the U.S. Army Corps of Engineers (USACE), Nashville District (LRN), Project 448755, "LRN Pickwick Lock." This work was conducted in the Coastal and Hydraulics Laboratory (CHL) of the U.S. Army Engineer Research and Development Center (ERDC). Design and construction of the model and model experiments were conducted during the period of November 2016 to June 2017.

This research was conducted under the general direction of Mr. José E. Sánchez, former Director of the CHL; Mr. Jeffrey Eckstein, Deputy Director, CHL; Dr. Jackie S. Pettway, Chief of the Navigation Division, CHL; and Mr. Tim Shelton, Chief of the Navigation Branch, CHL. Mr. Benjamin Rohrbach served as the technical point of contact in USACE, LRN. Members of LRN traveled to CHL to observe model operation, discuss test results, and determine the need for modifications in design to improve the hydraulic performance of the lock culvert valves.

The model components were constructed and assembled by Mr. Zachary S. Smith, Mr. Hugh F. Acuff III, Mr. Jason Ables, Mr. Mark Daniels, Mr. Hayden Skipper, and Mr. Chase Towne, Directorate of Public Works (DPW), ERDC, under the supervision of Mr. John E. Gullett, Chief of Model Shop, DPW. Machine work was provided by Mr. Christopher M. Ables under the supervision of Mr. Mickey D. Blackmon, Chief of the Machine Shop, DPW.

At the time of publication of this report, Mr. Charles E. Wiggins was the ERDC Technical Director for Civil Works, and Navigation Research, Development, and Technology Transfer portfolio.

COL Ivan P. Beckman was Commander of ERDC, and Dr. David W. Pittman was Director of ERDC. 


\section{Unit Conversion Factors}

\begin{tabular}{|l|l|l|}
\hline Multiply & \multicolumn{1}{|c|}{ By } & To Obtain \\
\hline cubic feet & 0.02831685 & cubic meters \\
\hline degrees (angle) & 0.01745329 & radians \\
\hline feet & 0.3048 & meters \\
\hline inches & 0.0254 & meters \\
\hline kips & 4448.221 & Newtons \\
\hline miles (U.S. statute) & 1.60947 & kilometers \\
\hline pounds (force) & 4.44822 & Newtons \\
\hline pounds (force) per square inch & 6894.7548 & Newtons per square meters \\
\hline tons (force) & 8896.44 & Newtons \\
\hline
\end{tabular}




\section{Introduction}

Pickwick Lock (Figure 1) is located at River Mile 206.7 on the Tennessee River (Figure 2). The lock was designed and constructed by the Tennessee Valley Authority (TVA), but the U.S. Army Corps of Engineers (USACE), Nashville District (LRN), is responsible for its operation and maintenance. LRN requested assistance from the U.S. Army Engineer Research and Development Center, Coastal and Hydraulics Laboratory (ERDC-CHL), in determining a replacement lock culvert valve.

Figure 1. Photograph of Pickwick Lock.

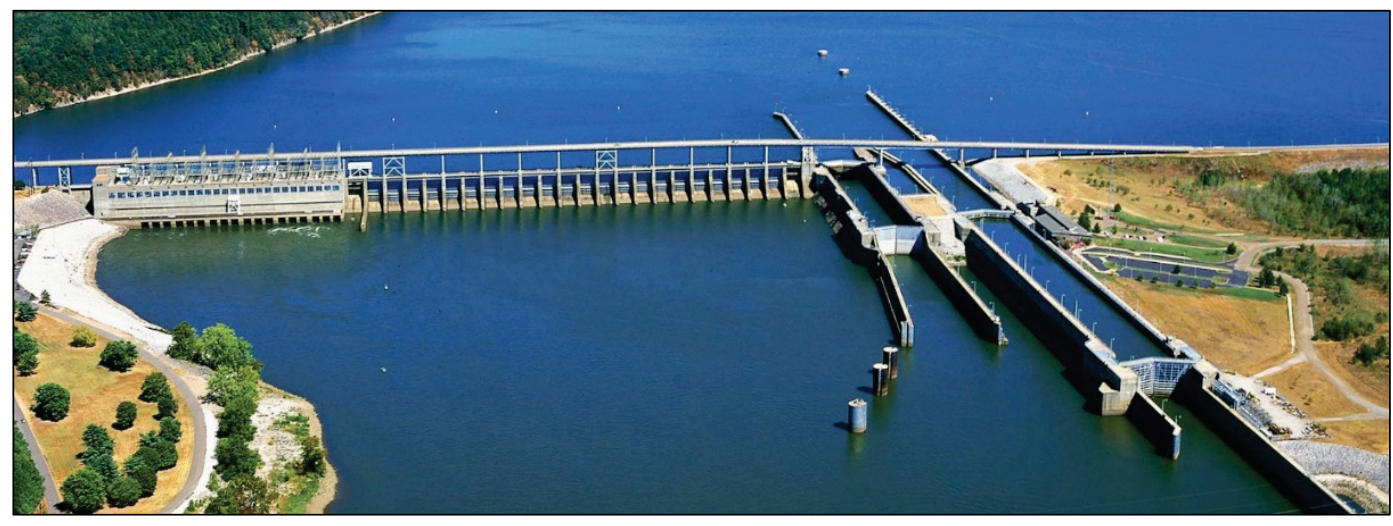

Figure 2. Pickwick Lock location.

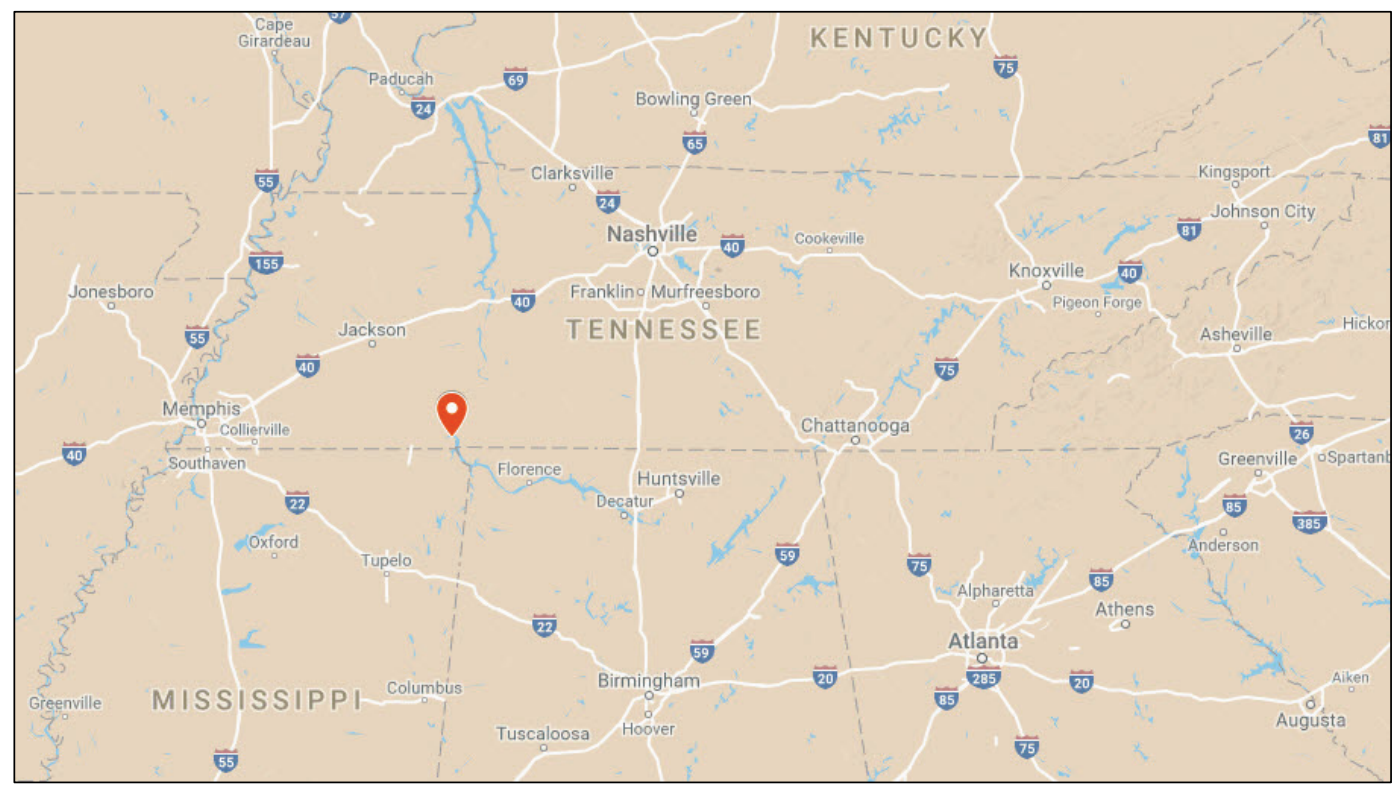




\subsection{Background}

Pickwick Lock has been in service since 1984. The original lock culvert valves have required significant repairs. Shortly after being installed, the lower valve sections experienced broken welds in the skin plate connections. In 2003 and 2004, both filling valves had weld failures at the connection of the radial arms and the horizontal girder. The river wall emptying culvert experienced a complete failure of the upper radial arm at the connection to the trunnion assembly weldment in 2014. During a dive inspection in September 2016, a large crack at the gusseted point where the valve arm attaches to the main girder was found on the river wall filling valve (Figure 3). Those gussets had been added during repair work in 2008.

Figure 3. Crack found in gusseted plate on valve, September 2016.

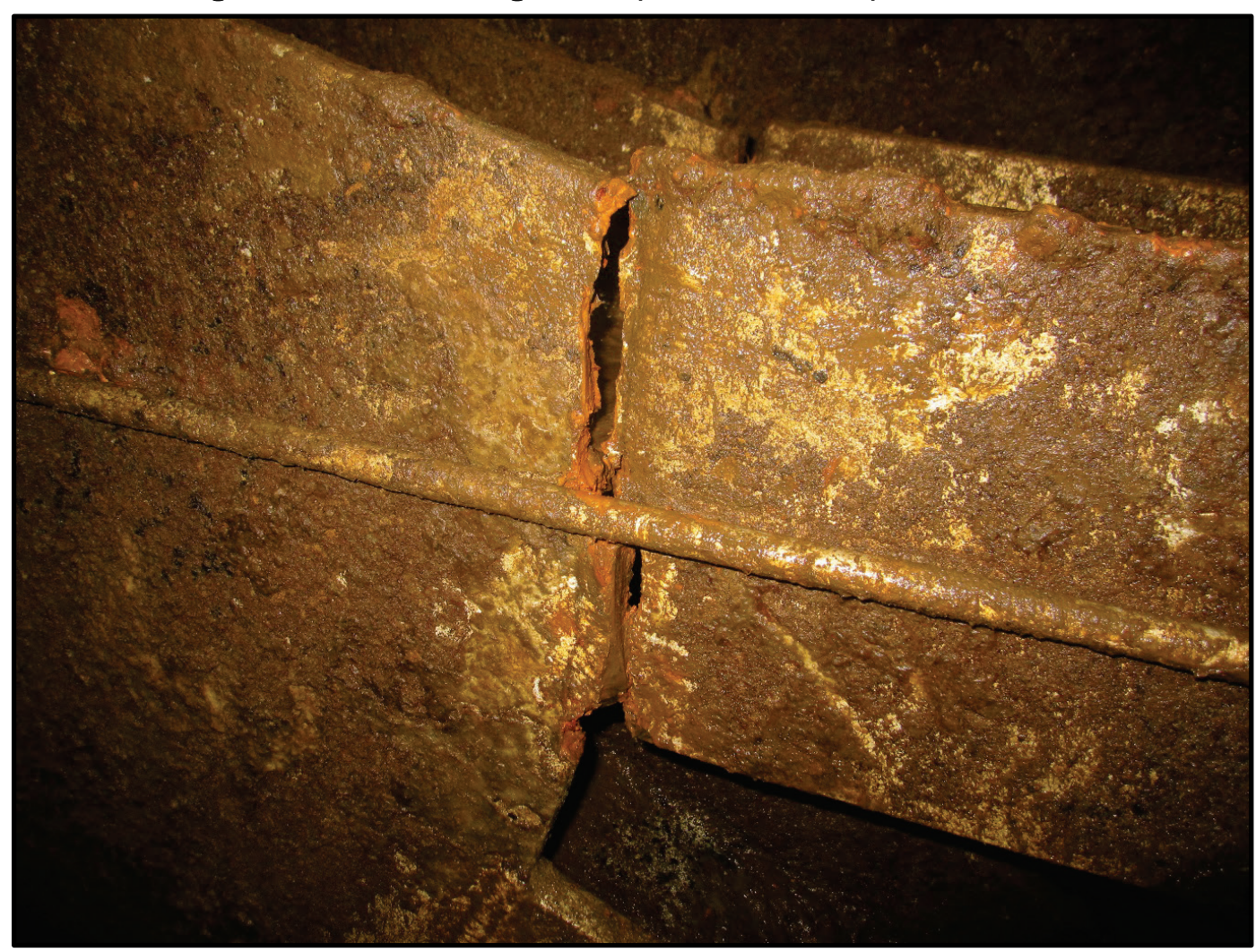

LRN suspects that the original valve design did not properly account for dynamic loading experienced during typical filling and emptying operations. USACE districts that control locks and dams have issues with lock culvert valves. Replacing the existing valves with valves that have reinforced beams, girders, and skin plates is not always a beneficial solution. Some replacement valves develop cracks after a few years of use. 
Solutions, using reinforced parts, create varying levels of improvement over the original valves. Analyses are often implemented to study the loads the lock culvert valves experience. The design of replacement valves is then improved using these analyses.

\subsection{Objective}

The objective of this study is to perform a hydraulic analysis of the existing Pickwick Lock culvert valve design and recommend a replacement valve design.

\subsection{Approach}

The hydraulic analysis is performed using a physical model of a portion of the lock culvert around the valve. The model replicates the flow behavior near the valve and allows the hydraulic forces acting upon the valve to be accurately reproduced. The second portion of this study is the hydraulic evaluation of the replacement valve design. The recommended replacement valve design (the "modified valve") is based upon ERDC experience with lock culvert valve studies and current USACE design guidance. Problem areas of the valve are identified and altered for the modified valve design. Only one valve is tested, but the recommended modified valve design is appropriate for the four replacement valves at Pickwick Lock.

LRN and ERDC-CHL develop the modified valve design jointly, and the existing and modified valve designs are evaluated in the physical model culvert. Comparisons are made of the forces acting upon the two valve designs, and a replacement valve design for Pickwick Lock is recommended. 


\section{Relevant Physics}

This chapter discusses the physical considerations of modeling hydraulic forces on a lock culvert valve during the filling and emptying operation of the lock.

\subsection{Flow behavior near reverse tainter valves}

During a lock filling and emptying operation, the lock culvert valves control the flow into and from the lock chamber. These valves are positioned in the lock culverts at the upper and lower ends of the filling and emptying system. At Pickwick Lock, the culvert valves are reverse tainter valves. Common components of a reverse tainter valve are shown in Figure 4. A typical installation of a reverse tainter valve is shown in Figure 5 .

Figure 4. Typical reverse tainter valve components.

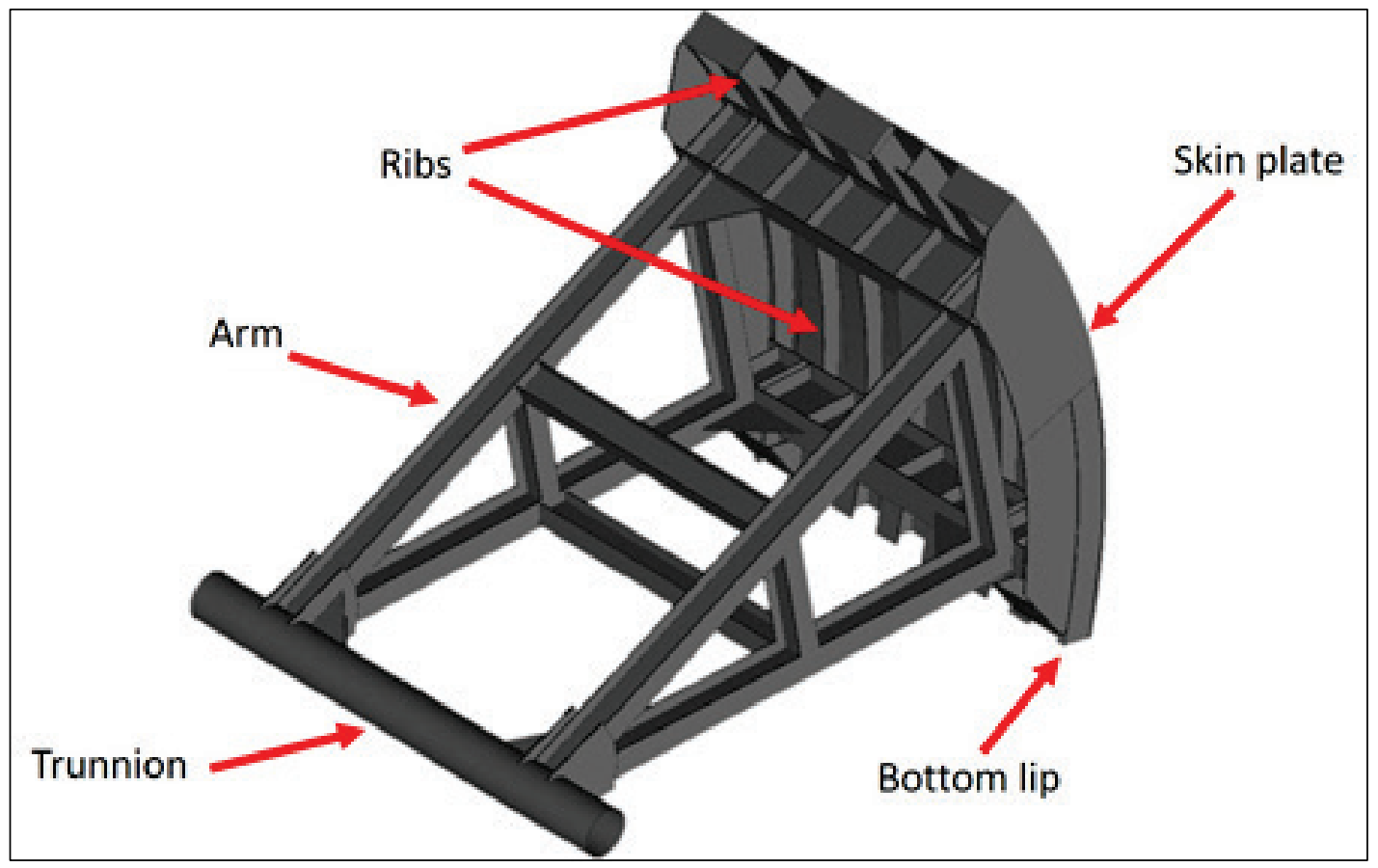


Figure 5. Typical installation of a reverse tainter valve.

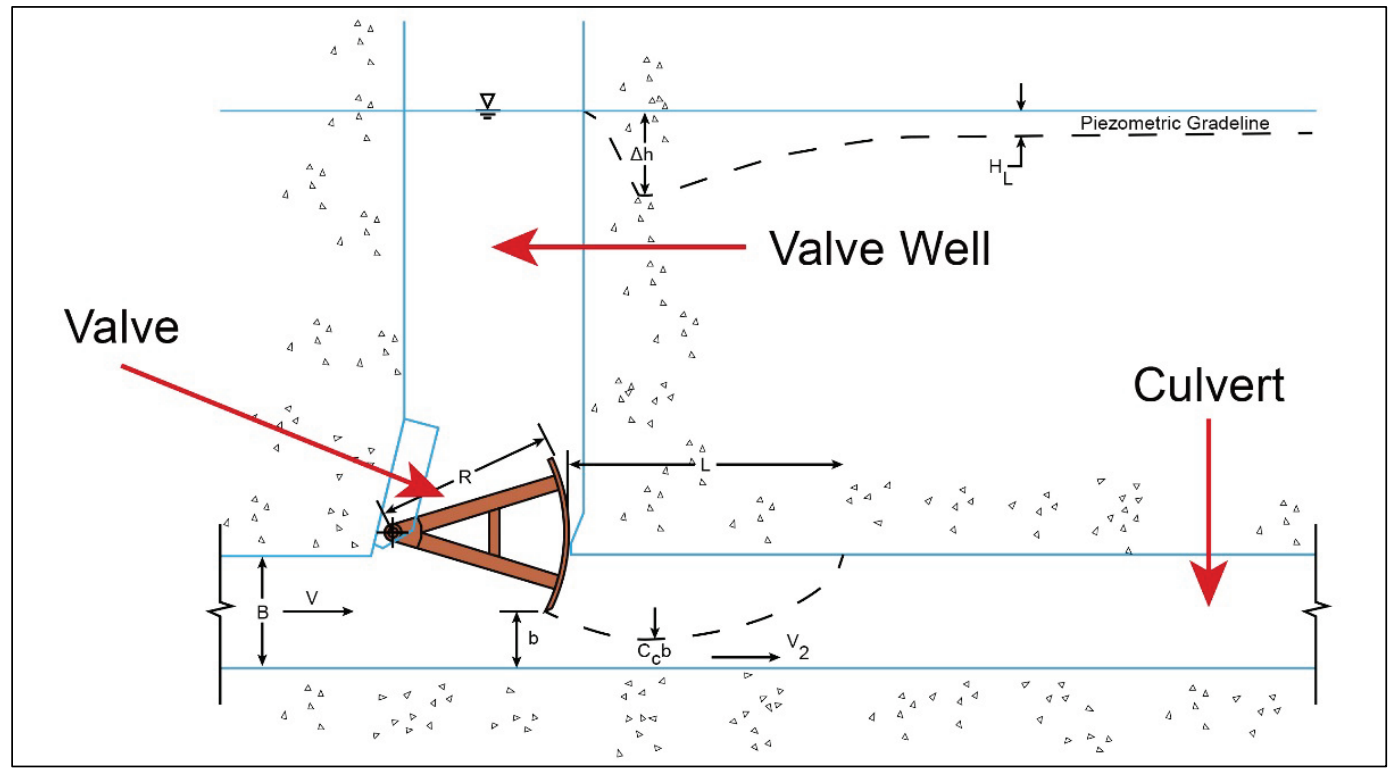

Control of the discharge, increasing or decreasing, in the culvert is accomplished by raising or lowering the valve using a connection near the top of the skin plate, causing the valve to rotate about the trunnion. Figure 6 (HQUSACE 1975) shows a typical reverse tainter valve at two positions during a filling and emptying operation. In these two images shown in this figure, the flow is moving from left to right. With the valve partially open, the flow bifurcates with the majority going underneath the valve and the remainder flowing into the valve well above the valve.

Figure 6. Typical flow patterns around a reverse tainter valve.

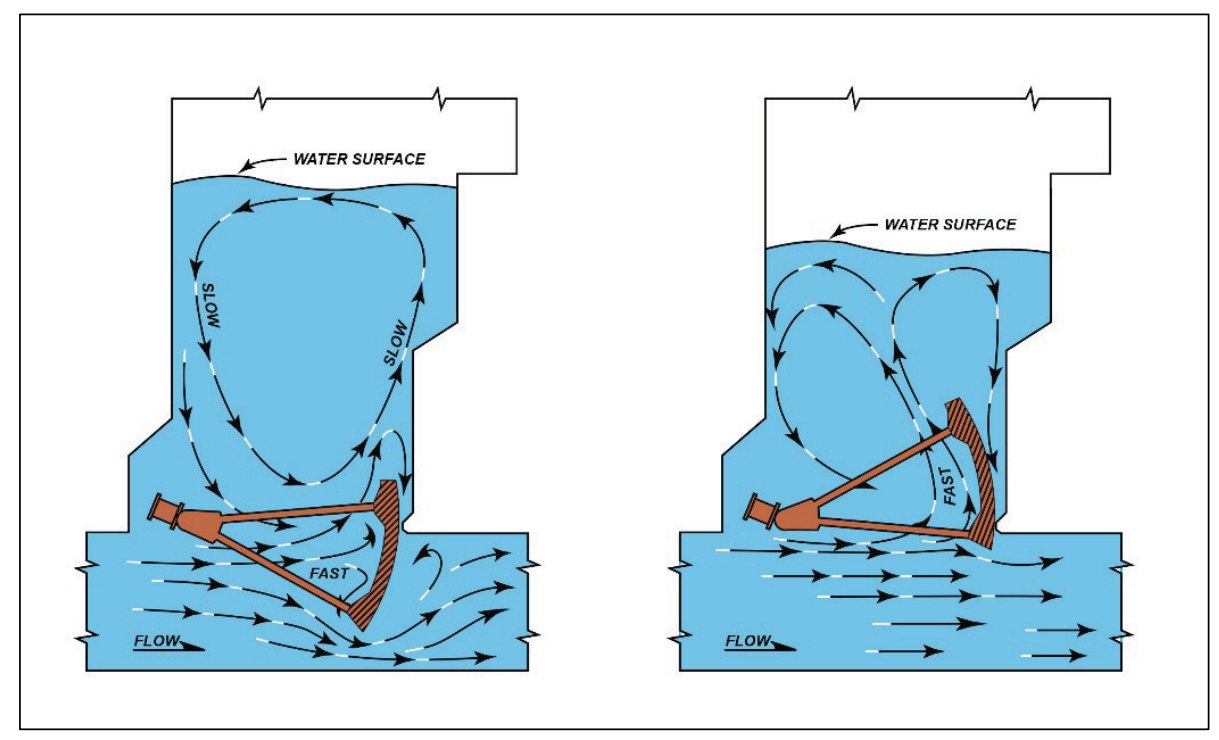


The flow field near a valve can change rapidly throughout a filling and emptying operation depending on the valve opening speed. Consequently, the hydraulic forces acting on the valve and any associated reaction forces are also functions of the valve position. Typically, a non-dimensional opening distance (b/B, Figure 7) describes the valve position, where "b" is the vertical distance from the bottom tip of the valve to the culvert floor and " $\mathrm{B}$ " is the culvert height in the immediate vicinity of the valve (both upstream and downstream of the valve).

Figure 7. Schematic of valve opening dimensions.

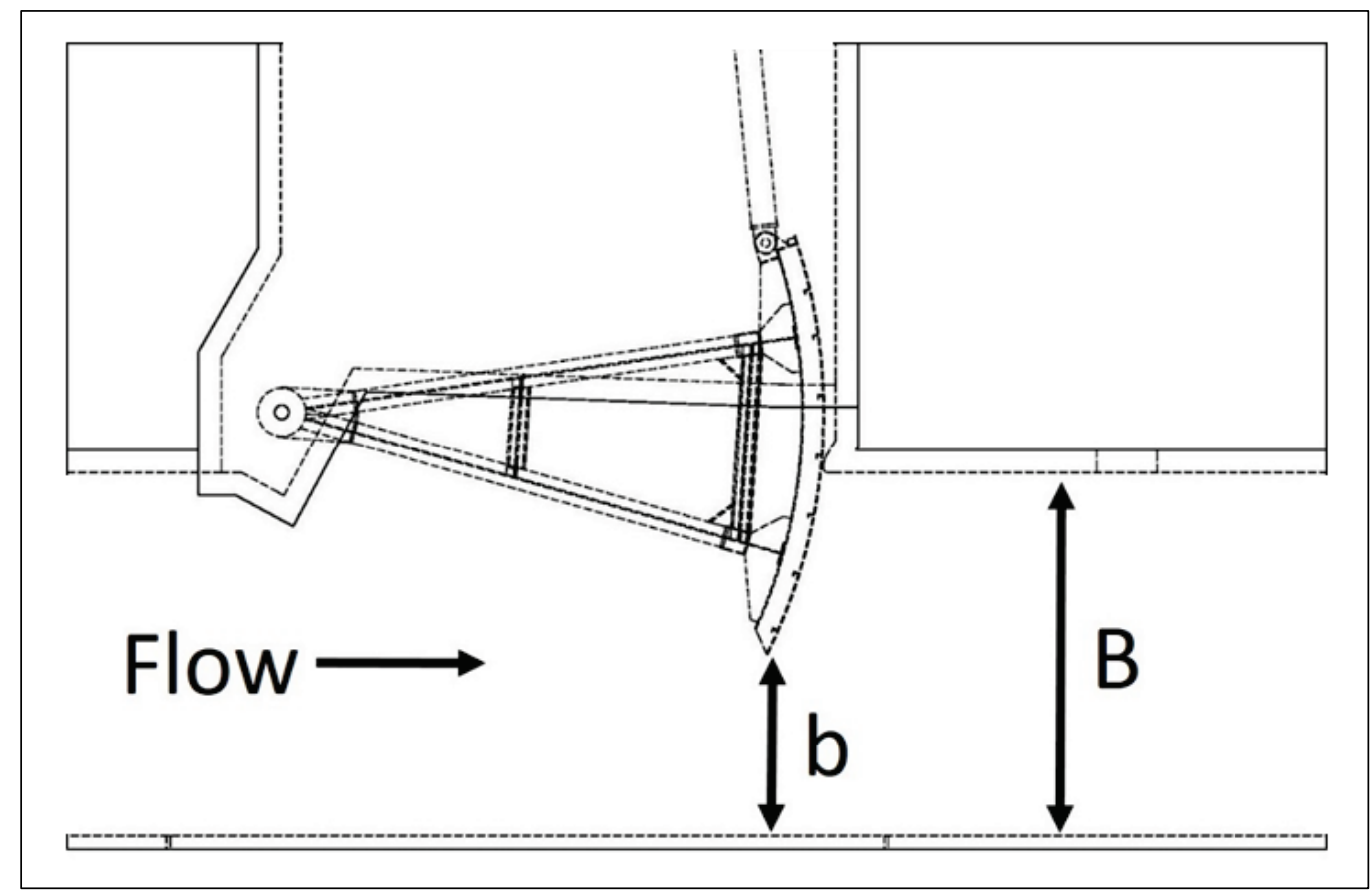

The flows near a reverse tainter valve during a lock filling and emptying operation are comprised of multiple flow regimes. In the culvert, the flow upstream of the valve is pressure-dominated, potential flow. Free-surface behavior dominates the flow in the valve well, and a submerged jet is formed immediately below and downstream of the valve. Immediately downstream of the skin plate is an area of lower pressure that is dominated by turbulent mixing. Each of these behaviors varies as the valve opens and closes, which changes the discharge approaching the valve.

\subsection{Forces acting on reverse tainter valves}

The interactions of these flow regimes dictate the behavior of the flow around the valve and in turn, determine the net forces acting on the valve. The forces acting on a reverse tainter valve include the valve weight, the 
hoist load transferred from the strut of the lift mechanism connected to the valve, the vertical and longitudinal trunnion loads, and the forces the water places on the valve. The valve will experience three different general situations: dry (no water in the culvert), hydrostatic (stationary water in the culvert), and hydrodynamic (flowing water in the culvert).

The hydraulic forces are the sum of hydrostatic and hydrodynamic forces due to accelerations as flow passes the valve.

In the dry case, the only forces acting on the valve are the valve weight and the reaction forces acting at the two support points - the trunnion and the connection (lift point) between the valve and the lower strut of the lift mechanism. This occurs when the valve has been dewatered for inspections and maintenance.

When the lock chamber is either at the upper pool elevation or at the lower pool elevation, the valves are submerged, but there is no flow. The presence of this stationary water introduces a buoyant force on the valve. The buoyant force is directed upward, so the resulting reaction forces are lower than the corresponding dry load reaction forces.

Lock culvert valves also experience the hydrodynamic case, which occurs during lock filling and emptying operations. This case is the primary concern with lock culvert valves because the forces acting on the valve caused by the flowing water are not only larger than those of the dry and hydrostatic cases, but they change orientation with the valve's position. Due to the rapidly varying flows and the complicated geometry of the valve, calculating the hydrodynamic forces is extremely difficult. The hydrodynamic force can be separated into two main components - a longitudinal component (along the culvert in the predominant direction of flow) and a vertical component.

Forces the water places on the valve depend upon the valve geometry and its position (b/B) during the filling and emptying operation. Current design guidance found in EM 1110-2-1610 (HQUSACE 1975) shows how the valve geometry affects the average forces acting upon the valve during operation. Experience shows that the best compromise between structural and hydraulic performance is the vertically framed valve. This is the recommended open-frame design. Such a specification does not completely describe what the exact geometry of a valve at a particular lock 
should look like, so an evaluation with site-specific parameters is suggested before any final design is determined. These site-specific studies use physical models to provide guidance on what the hydraulic forces acting upon a valve during operation will be. The valve can then be designed to withstand those forces. A free-body diagram of the valve showing these forces is shown in Figure 8. The forces labeled are the trunnion force $T$ (with longitudinal component $T_{L}$ and vertical component $T_{V}$ ), the hoist load $P$, the angle $\alpha$ (the angle the long strut connected to the valve makes with the vertical), the valve weight $W$, the hydraulic/hydrodynamic force $H$ (with longitudinal component $H_{L}$ and vertical component $H_{V}$ ).

Figure 8. Free-body diagram of a reverse tainter valve subjected to flow.

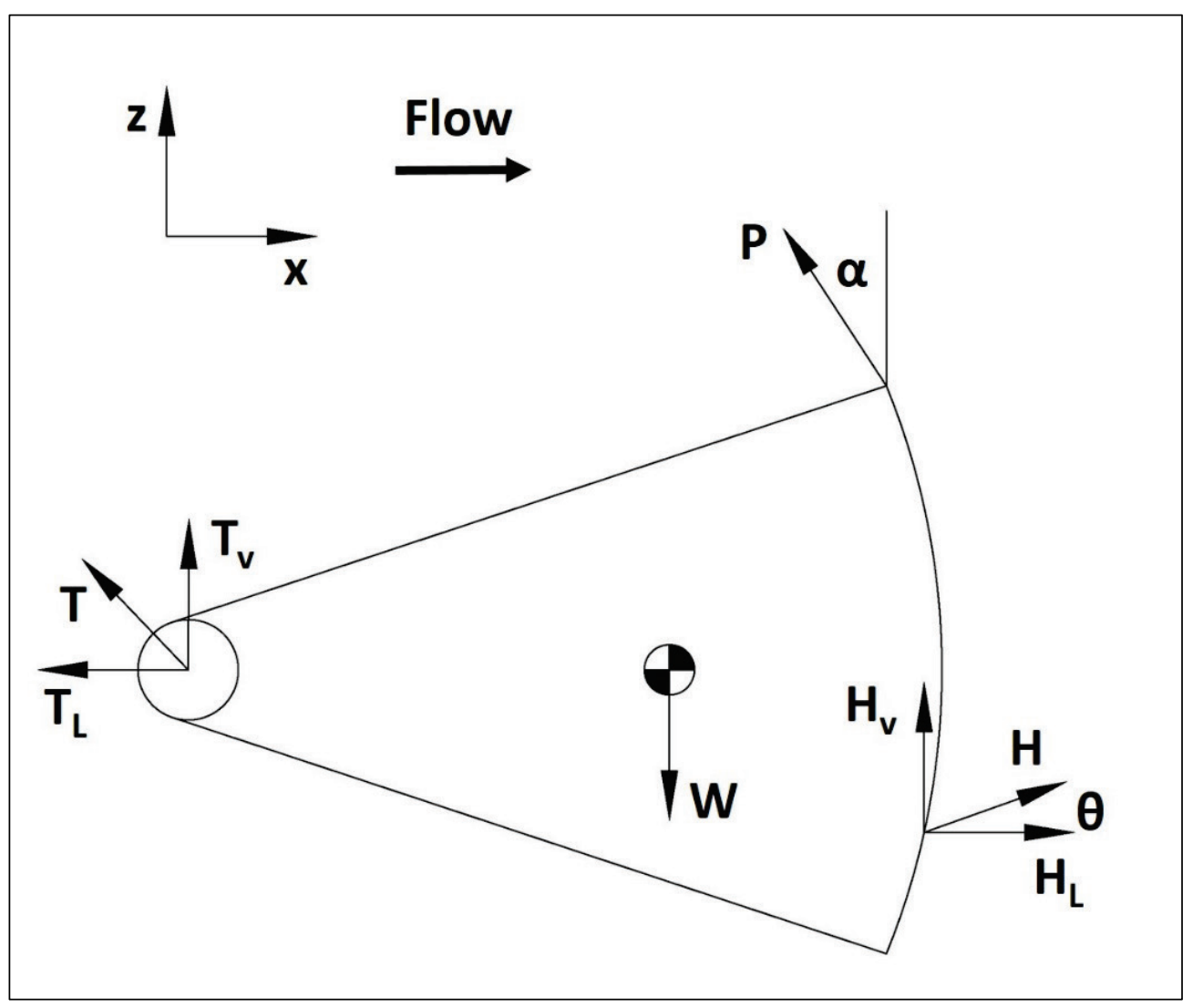

The total trunnion force is the vector sum of the longitudinal and vertical components of the hydraulic/hydrodynamic force, so

$$
T=\sqrt{T_{L}^{2}+T_{V}^{2}}
$$


The total hydraulic force is the vector sum of the longitudinal and vertical components of hydraulic force, so

$$
H=\sqrt{{H_{L}}^{2}+H_{V}^{2}}
$$

The valve is assumed to be in equilibrium, and the forces across the lock culvert (lateral direction) are assumed to be negligible. Applying equilibrium conditions to the valve creates correlations that can be used to calculate the magnitude of the hydraulic/hydrodynamic forces acting on the valve during the filling and emptying operation as well as the line of action of the resultant hydraulic/hydrodynamic force.

For all equilibrium calculations, a coordinate system is chosen with the origin at the center of the trunnion, the positive $\mathrm{x}$-direction (longitudinal direction) is along the primary direction of flow, the positive lateral direction is directed toward the reader, and the positive z-direction (vertical direction) is up, towards the valve well.

Applying the equilibrium requirement to the equation of motion for the longitudinal direction gives

$$
\sum F_{x}=0=>H_{L}-P \sin \alpha-T_{L}=0
$$

So,

$$
H_{L}=P \sin \alpha+T_{L}
$$

Applying the equilibrium condition to the equation of motion in the vertical direction gives

$$
\sum F_{z}=0=>P \cos \alpha+H_{V}+T_{V}-W=0
$$

So,

$$
H_{V}=W-P \cos \alpha-T_{v}
$$

Upward hydraulic forces provide upward thrust to the valve and are thus referred to as uplift forces. Similarly, downward hydraulic forces provide downward thrust to the valve and are referred to as downpull forces. 
Applying the equilibrium condition to the rotational equation of motion about the trunnion axis using the total hydraulic force $H$, assuming counterclockwise moments are positive, produces the third equilibrium relation:

$$
\sum M_{T}=0=>(P \cos \alpha) x_{P}+(P \sin \alpha) z_{P}+H d_{H}-W x_{C G}=0
$$

So,

$$
d_{H}=\frac{W x_{C G}-(P \cos \alpha) x_{P}-(P \sin \alpha) z_{P}}{H}
$$

Where $x_{p}$ is the longitudinal distance from the trunnion that the hoist load acts, $z_{p}$ is the vertical distance from the trunnion that the hoist load acts, $\mathrm{dH}$ is the moment arm of the hydraulic force about the trunnion, and $x_{C G}$ is the longitudinal distance from the trunnion to the valve's center of mass.

The point where the hydraulic forces act is referred to as the center of pressure. The longitudinal and vertical locations of the center of pressure cannot be calculated directly using just the equilibrium conditions because these three equations have four unknown quantities - the two components of the hydraulic force and the two coordinates of the location of the center of pressure. However, enough information is known to calculate the line of action of the resultant hydraulic force using just the equilibrium conditions (Equations 6, 8, and 10). This line of action has a general form:

$$
z=m x+b
$$

where $m$ is the slope of the line and $b$ is the z-intercept of the line.

For the line of action of the resultant hydraulic force, the slope $m$ is the ratio of the vertical component to the longitudinal component, so

$$
m=\tan \theta=\frac{H_{V}}{H_{L}}
$$

The z-intercept (vertical axis intercept) of the line of action can be found by extending the line of action of the resultant hydraulic force to the vertical axis. The point of intersection of the hydraulic force line of action and the vertical axis is the z-intercept in question. A right triangle (shown 
in Figure 9) is formed by the hydraulic force, the hydraulic force moment arm about the trunnion, and the vertical axis. Therefore, the z-intercept is

$$
\cos \theta=\frac{d_{H}}{b}=>b=\frac{d_{H}}{\cos \theta}
$$

Figure 9. Valve moment balance geometry.

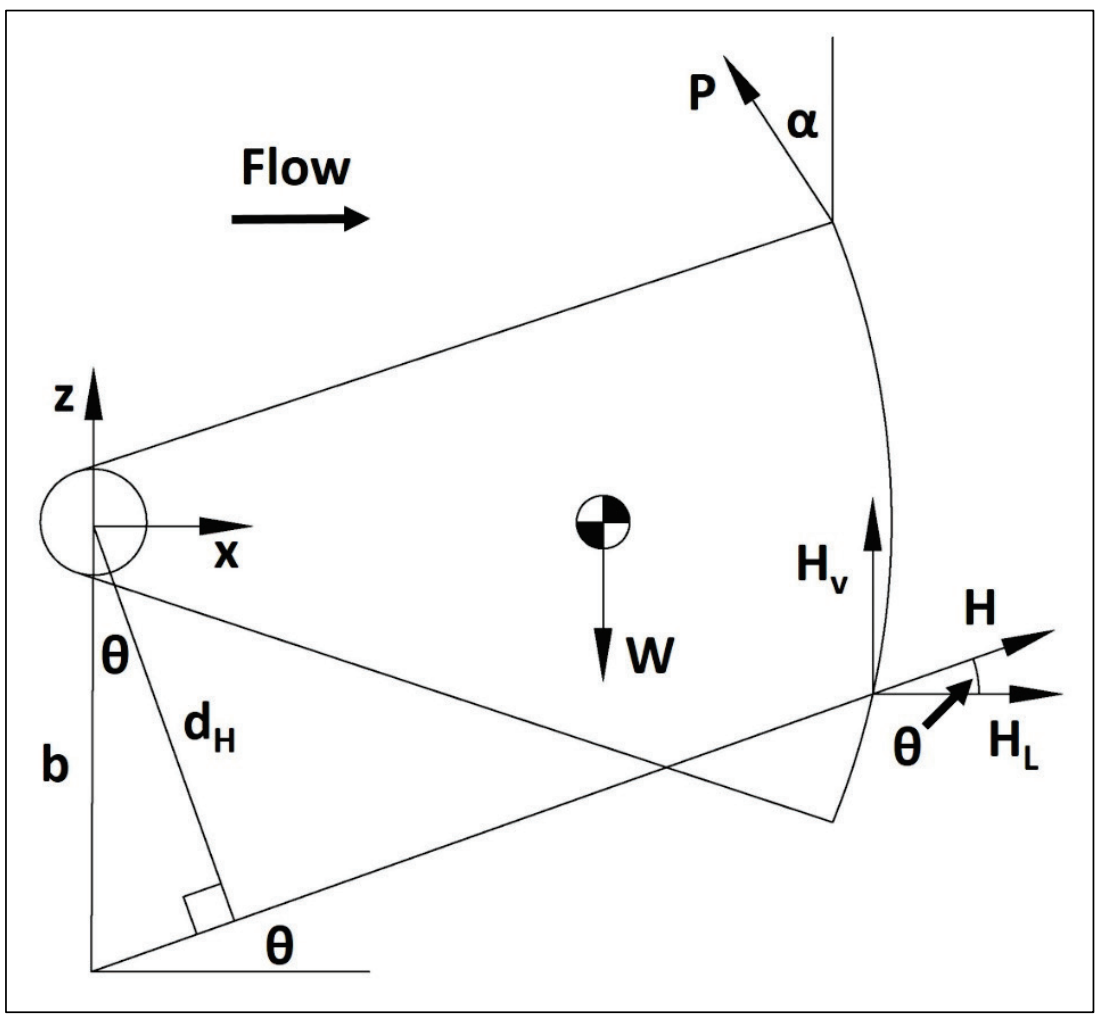

Substituting Equation 14 and Equation 15 into Equation 13 produces

$$
z=\tan \theta x+\frac{d_{H}}{\cos \theta}
$$

This defines the line of action of the resultant hydraulic force in terms relevant to the valve scenario being studied.

\subsection{Similitude considerations}

The complex flows around the lock culvert valves must be reproduced adequately. This reproduction ensures the information about the forces can be scaled to provide accurate estimates of the prototype-scale forces that act on the valve. Currently, a scaled physical model that includes the valve and portions of the lock culvert near the valve is the tool of choice for such evaluations. To ensure that the forces measured in the model are 
appropriate for scaling to prototype scale, the model must be scaled according to specific criteria. Foremost, the model must be dynamically similar to the prototype. Models of the flows around hydraulic structures typically use water as the fluid, so dynamic similitude is achieved by ensuring that the differences in the viscous forces in the model and the prototype are negligible.

\subsubsection{Dynamic similitude}

Scaling of viscous forces requires the model to be dynamically similar to the prototype. Dynamic similarity is achieved when the ratios of the inertia forces $\left(\rho V^{2} L^{2}\right)$ to the viscous forces $(\mu V L)$ for both the model and prototype are equal. Here, $\mu$ is the fluid viscosity, $V$ is some characteristic velocity, and $L$ is some characteristic length. This ratio of inertial forces to viscous forces is usually expressed as the Reynolds number, $R e$ :

$$
R e=\frac{V L}{v}
$$

where $v$ is the kinematic viscosity of the fluid $(v=\mu / \rho)$.

In pressure flow analysis, the pipe/culvert hydraulic diameter is usually chosen as the characteristic length, $L$. Since water is the fluid in both the model and prototype, the Reynolds number in the model must be large enough to avoid any significant viscous effects differences between the model and the prototype.

\subsubsection{Kinematic similitude}

Kinematic similitude is appropriate for modeling gravity-driven flows in which the viscous forces are negligible. Flows through navigation lock culverts are gravity driven, so kinematic similitude is the appropriate method to ensure that flow behavior in the model is analogous to flow in the prototype. Kinematic similitude requires the ratio of the inertial forces to the gravitational forces $\left(\rho g L^{3}\right)$ in the model is equal to those of the prototype. This ratio is generally expressed as the Froude number, Fr:

$$
F r=\frac{V}{\sqrt{g L}}
$$

For closed conduit flow, the characteristic length $L$ is usually taken as the hydraulic diameter of the culvert. Equating the model and prototype 
Froude numbers produce correlations between the model's scale and its hydraulic quantities. These correlations are then used to scale quantities measured from the model study to prototype scale.

Kinematic similitude, and Reynolds numbers large enough to produce negligible viscous effects, accurately reproduces streamlines, and therefore the fluid accelerations and hydrodynamic forces. Viscous effects that affect the forces on the valve are flow separation points, and the location along the culvert where the flow streamlines along the entire culvert height are generally parallel to the culvert roof. These flow features produce zones of low pressure on the backside of flow obstructions such as a partially opened valve protruding into the flow. Since the point of flow separation is fixed at the lower lip of the valve for all flow conditions, viscous effects are independent of scale and velocity (Baines 1954).

\subsubsection{Pickwick Lock culvert valve model scale correlations}

For lock culvert valve model studies, model scales typically fall within a range of 1:10 to 1:20 (model dimension to prototype dimension). With the facilities available at ERDC-CHL and the scaling considerations, a 1:15 scale model for the Pickwick Lock culvert valve study is chosen. The scale correlations and subsequent scaling factors used for this study are shown in Table 1.

Table 1. Scale correlations for the Pickwick Lock culvert valve study.

\begin{tabular}{|l|l|l|}
\hline Characteristic & Dimension & $\begin{array}{l}\text { Scale Relation } \\
\text { Model: Prototype }\end{array}$ \\
\hline Length & $\mathrm{L}_{r}=\mathrm{L}$ & $1: 15$ \\
\hline Area & $\mathrm{Ar}_{\mathrm{r}}=\mathrm{Lr}^{2}$ & $1: 225$ \\
\hline Time & $\mathrm{T}_{\mathrm{r}}=\mathrm{L}_{r}{ }^{1 / 2}$ & $1: 3.8730$ \\
\hline Velocity & $\mathrm{V}_{\mathrm{r}}=\mathrm{L}_{r}{ }^{1 / 2}$ & $1: 3.8730$ \\
\hline Discharge & $\mathrm{Q}_{r}=\mathrm{L}_{r}{ }^{5 / 2}$ & $1: 871.421$ \\
\hline Force & $\mathrm{F}_{\mathrm{r}}=\mathrm{L}_{r}{ }^{3}$ & $1: 3,375$ \\
\hline Pressure & $\mathrm{P}_{r}=\mathrm{L}_{r}$ & $1: 15$ \\
\hline
\end{tabular}

${ }^{1}$ Dimensions are in terms of length. 


\section{Model Description and Modeling Process}

The Pickwick Lock culvert valve physical model consists of a scaled section of the existing Pickwick Lock culvert that contains the upstream bulkhead slot, the valve well, the valve, the downstream bulkhead slot, 146 feet ( $\mathrm{ft}$ ) (prototype) of the culvert upstream of the valve trunnion axis, and $163 \mathrm{ft}$ (prototype) of the culvert downstream of the valve trunnion axis. Upstream of this section, the model connects to an existing pipe, which supplies water to the model. Downstream of this section, the model connects to a section of culvert that directs the flow to a drain. Schematics of the physical model are shown in Figure 10 and Figure 11. An overall photograph of the constructed physical model is shown in Figure 12, and a close-up of the valve is shown in Figure 13.

Figure 10. Pickwick Lock culvert valve model schematic.

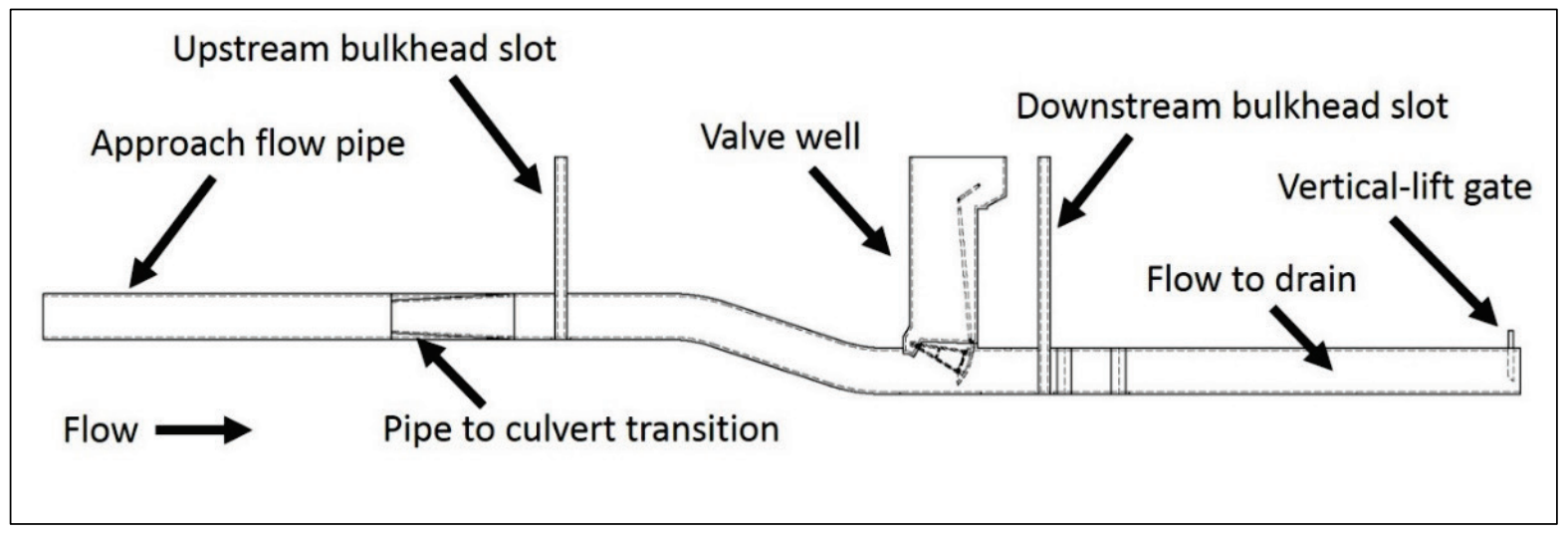


Figure 11. Pickwick Lock culvert valve model schematic - valve lift mechanism details.

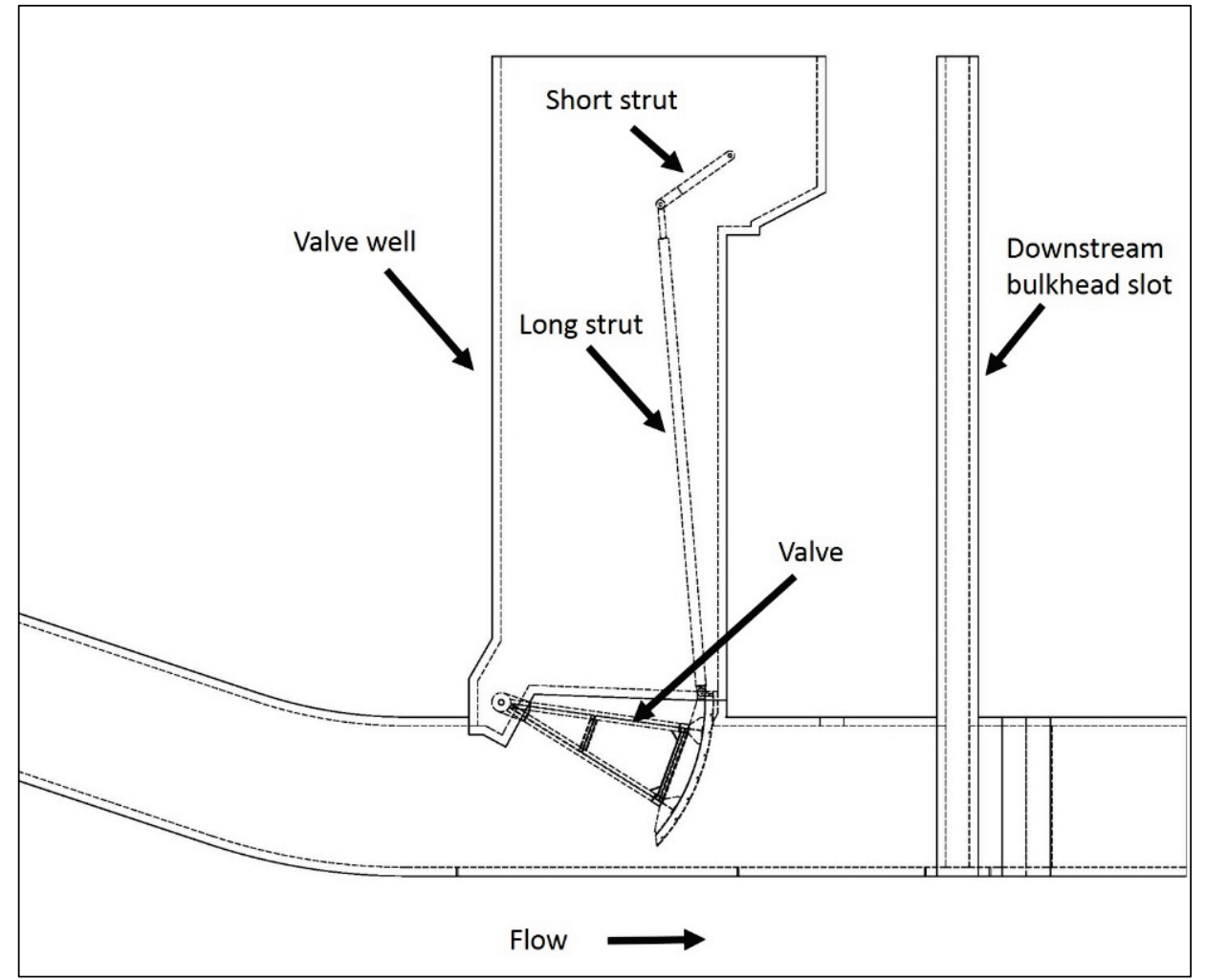

Figure 12. Pickwick Lock culvert valve physical model.

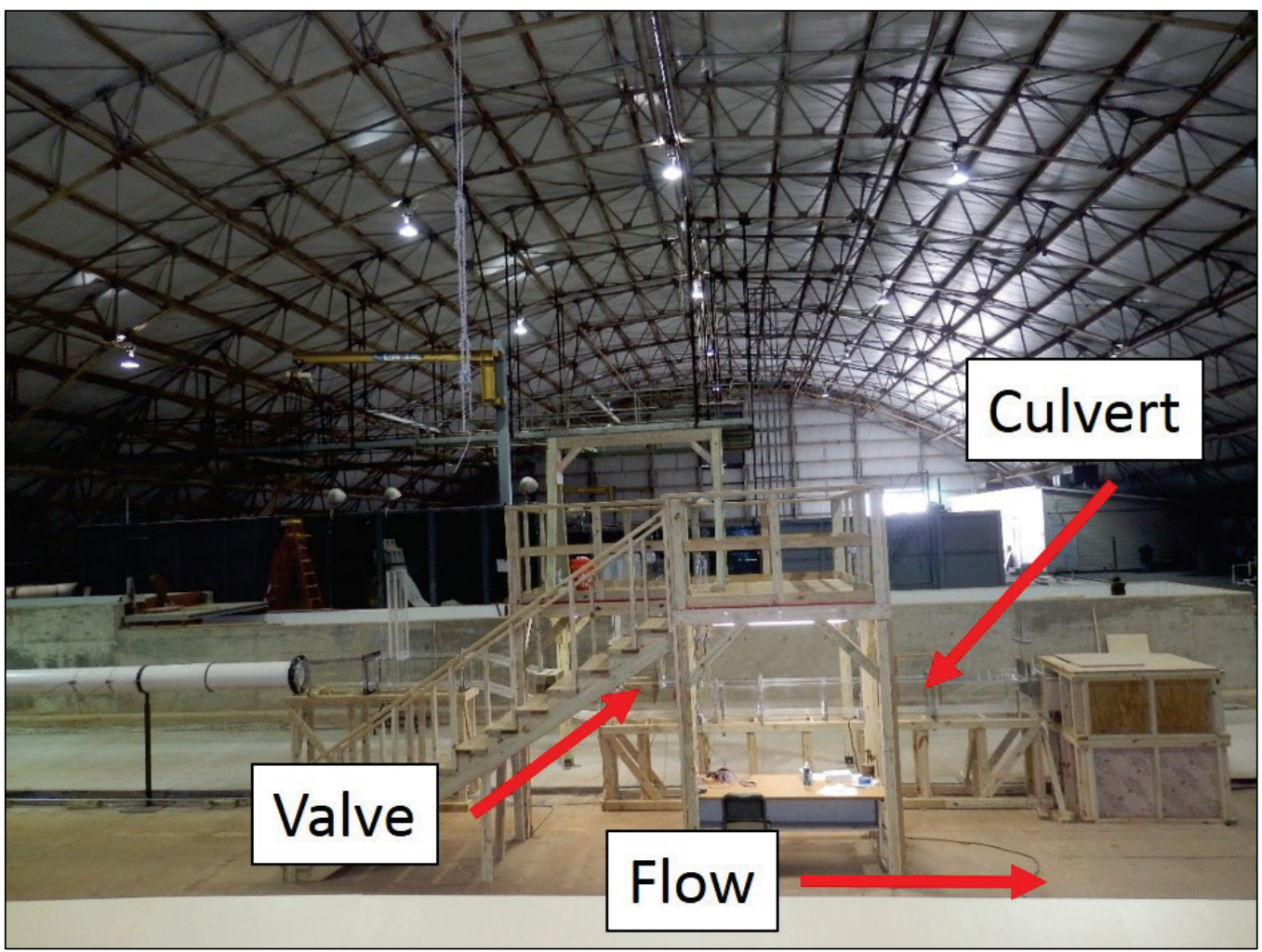


Figure 13. Pickwick Lock culvert valve physical model - valve close-up.

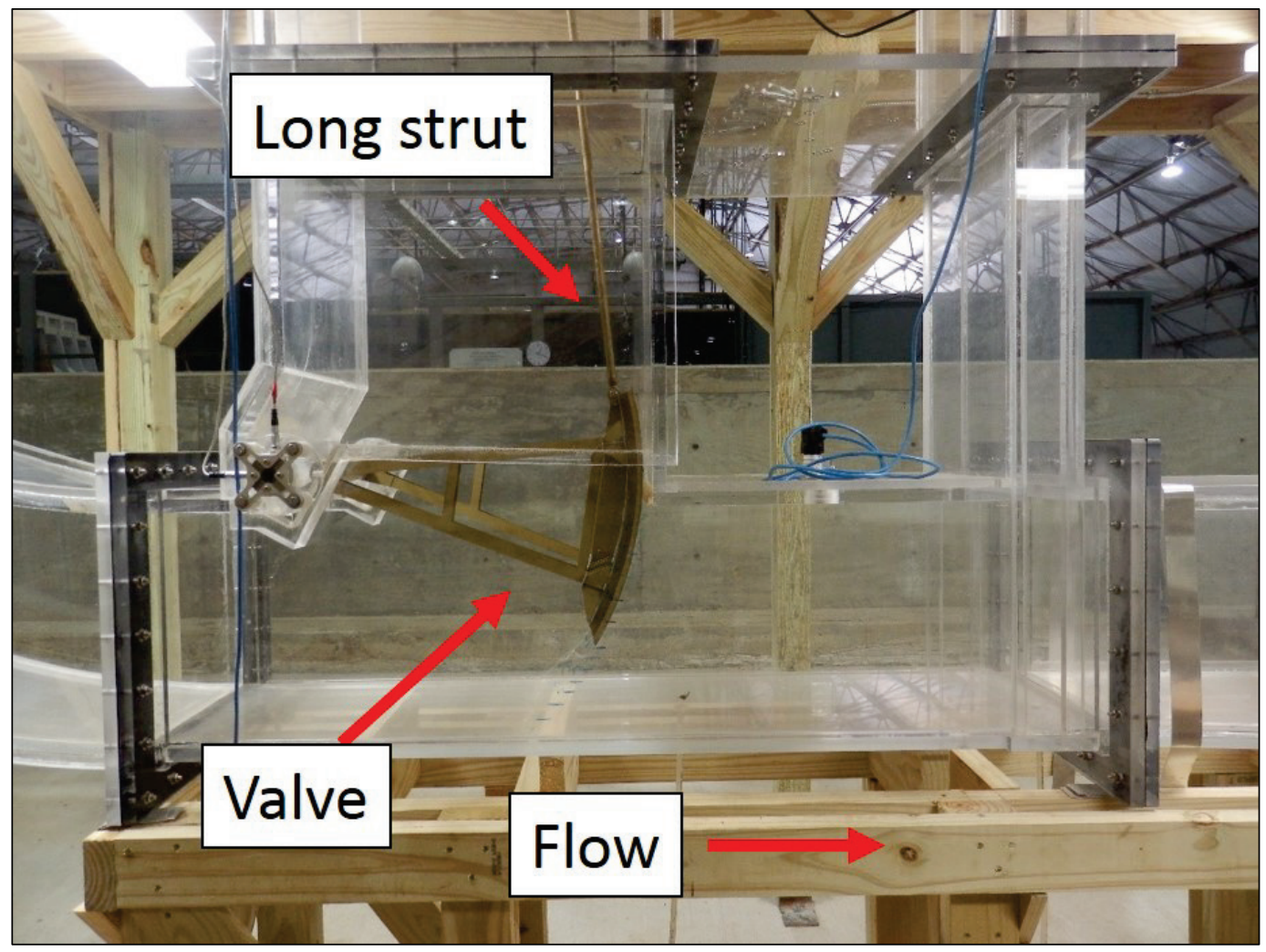

\subsection{Model description}

\subsubsection{Model construction}

Three-dimensional (3D) computer-aided design (CAD) models of the valve, two struts of the valve lift mechanism (long and short), and the culvert are constructed from as-built line drawings of Pickwick Lock. Valve side seals are excluded to reduce the amount of vibration damping present in the system and to provide conservative model results for the prototype design. The two struts are included in the model to hold the valve at the desired opening during testing and ensure the long strut (from which the hoist load is measured) has the same orientation as the long strut in the prototype. The lift mechanism is controlled by a winch and cable.

All culvert walls and the downstream gate are constructed of threequarter-inch (in.) acrylic. This material allows direct observation of flow around the valve and valve vibration during tests. The acrylic model walls are strong enough to withstand the weight of the model structure and the hydraulic forces during testing. The culvert sections are joined together, and gasket material is between each flanged section to prevent leakage. 
The valve well flanges allow the model to be disassembled so the different valve types can be installed easily.

The reverse tainter valves are constructed of brass. Components of the $3 \mathrm{D}$ CAD valve models are cut from sheet brass using a computer-operated water jet. These components are then soldered together to form the completed valve.

\subsubsection{Instrumentation}

The forces acting upon the valve are measured with two instruments one for the hoist loads (the axial force in the long strut connected to the tainter gate at the lift point) and another for the two components of load acting on the trunnion. Each of these instruments measure dynamic forces at a 50 -hertz $(\mathrm{Hz})$ rate.

The average pressure at locations along the model culvert are measured with piezometers connected to glass open-air manometers arranged on a board for convenient viewing (Figure 14). A commercial pressure transducer is used to measure the highly unsteady pressure in the zone immediately downstream of the valve skin plate. This pressure transducer was mounted $12 \mathrm{ft}$ (prototype) downstream of the valve ( 0.8 culvert heights) flush with the interior surface of the culvert soffit to enable pressure measurements without obstructing the flow. The transducer has a 1 in. diameter, with a measurement range from $o$ to 5 pounds per square inch (psi). Its measurement tolerance is $+/-0.025$ psi with an output of 420 milliamps. The pressure data are recorded at a rate of $50 \mathrm{~Hz}$. The location of the piezometers and pressure cell is illustrated in Figure 15 and listed in Table 2. 
Figure 14. Piezometer display board.

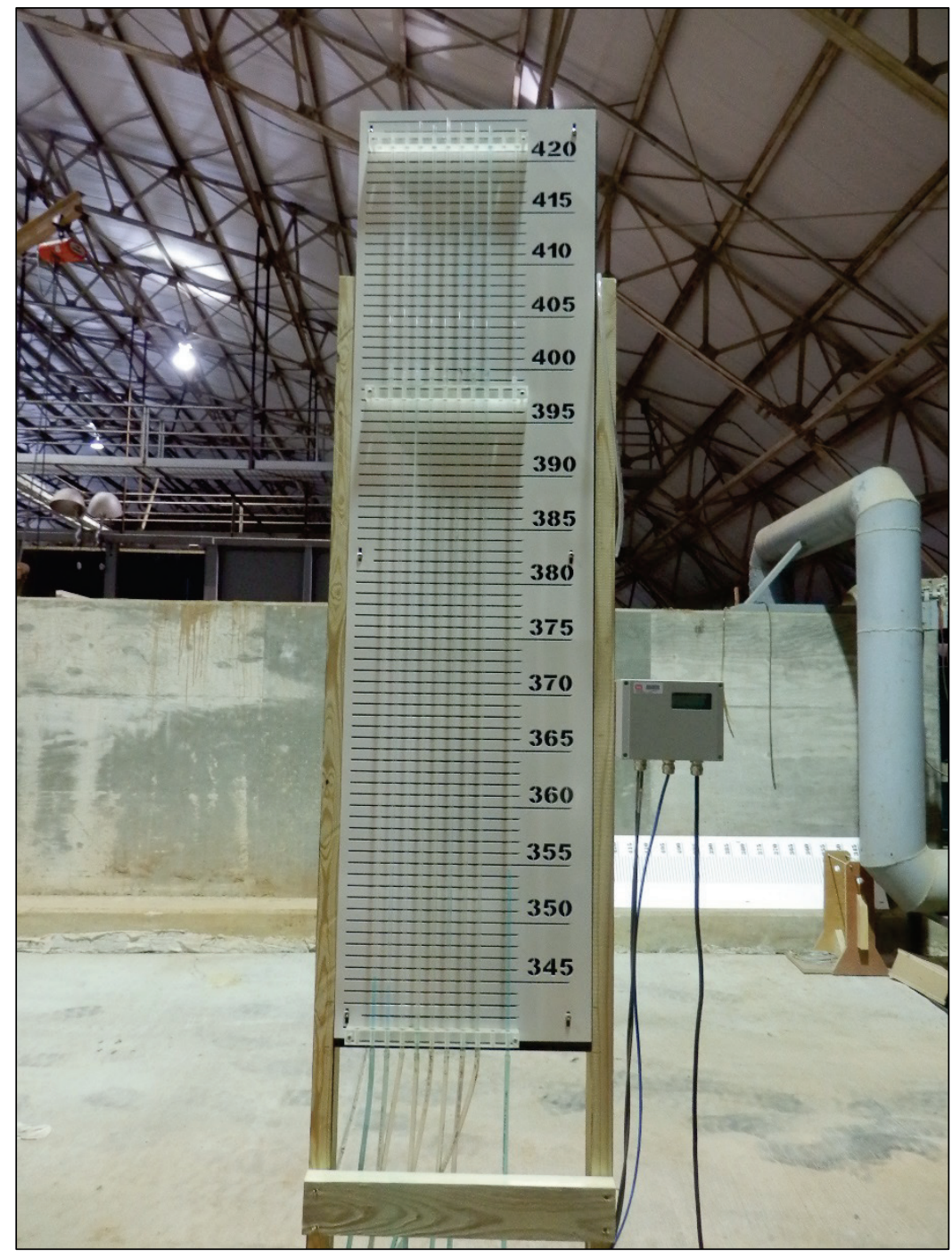

The hoist loads are measured using a commercial S-beam load cell (Figure 16) mounted in-line with the long strut (Figure 17). The load cell has a 25-pounds force (lbf) load capacity, a measurement tolerance rated at $+/-0.005 \mathrm{lbf}$, and a 1.0 millivolt/volt $(\mathrm{mV} / \mathrm{V})$ output. The trunnion loads are measured with a commercial bi-axial load arm (Figure 18) mounted at each end of the valve trunnion (Figure 19). This load arm measured two normal components of the force placed on the rod extending from the base, using a set of eight strain gauges (four for each force component) located inside the rod. The load arm is rated for a maximum load of $50 \mathrm{lbf}$, a tolerance of $+/-0.05 \mathrm{lbf}$, and a nominal output of $3.0 \mathrm{mV} / \mathrm{V}$. The flow rate through the model is measured with an ultrasonic flowmeter to ensure that the correct hydraulic conditions are being applied to the valve. This flowmeter uses ultrasonic transducers 
to measure the transit time of ultrasonic pulses into and against the direction of flow. This transit time is directly related to the average flow velocity. The analog output of the flowmeter is sampled at $50 \mathrm{~Hz}$ to align with the other time-dependent measurements recorded during all experiments.

Figure 15. Piezometer layout.

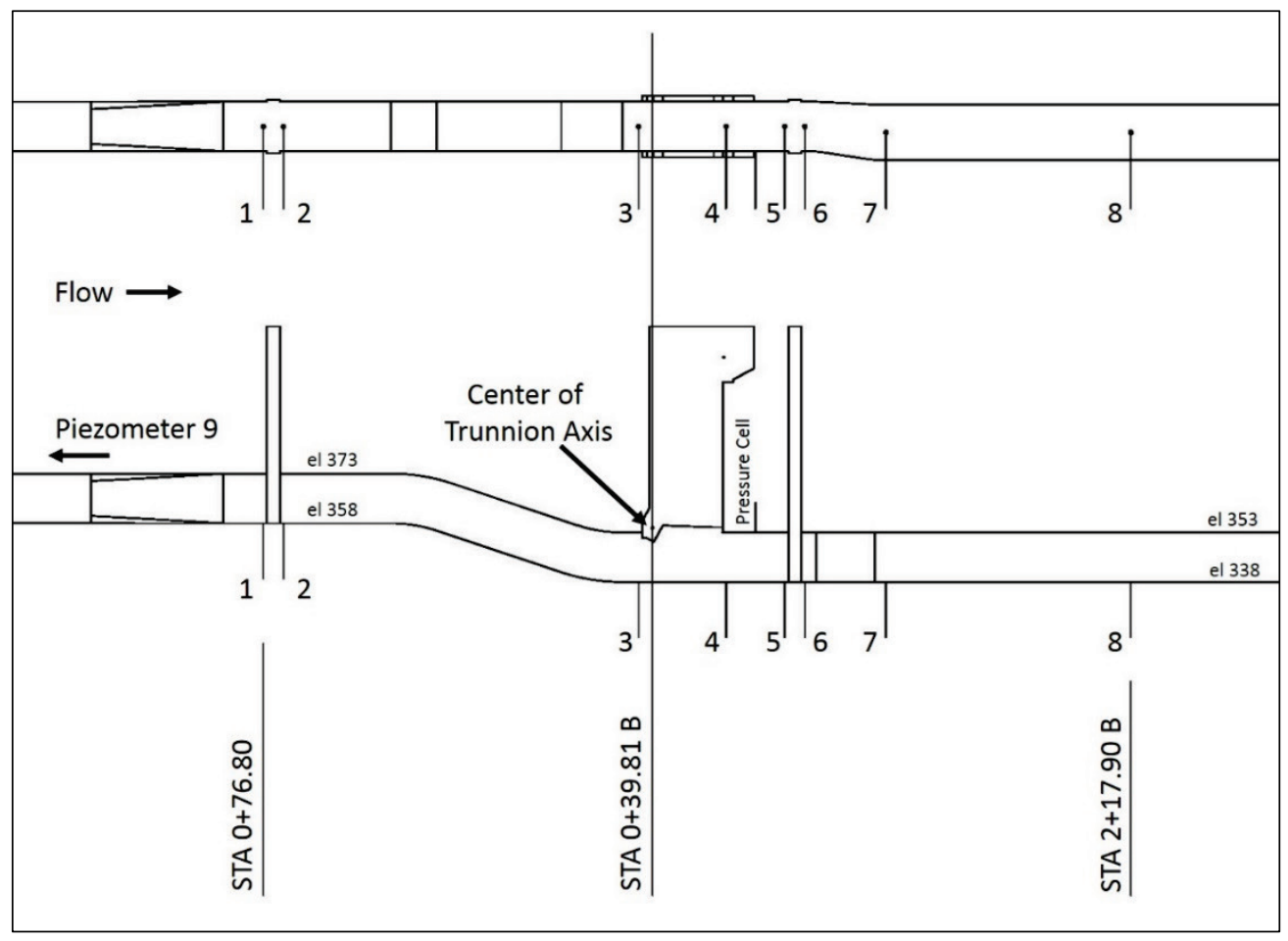

Table 2. Piezometer and pressure cell locations.

\begin{tabular}{|c|c|c|}
\hline Piezometer & Station* & Elevation (ft) \\
\hline 1 & $0+92 \mathrm{U}$ & 358 \\
\hline 2 & $0+86 \mathrm{U}$ & 358 \\
\hline 3 & $0+35 \mathrm{D}$ & 338 \\
\hline 4 & $0+65 \mathrm{D}$ & 338 \\
\hline 5 & $0+90 \mathrm{D}$ & 338 \\
\hline 6 & $0+92 \mathrm{D}$ & 338 \\
\hline 7 & $1+19 \mathrm{D}$ & 338 \\
\hline 8 & $2+02 \mathrm{D}$ & 338 \\
\hline Pressure Cell & 0+74 D & 353 \\
\hline
\end{tabular}

* " $\mathrm{U}$ " and " $\mathrm{D}$ " refer to distances upstream and downstream, respectively, from the trunnion center. 
Figure 16. Hoist load (force in long strut) measurement instrument.

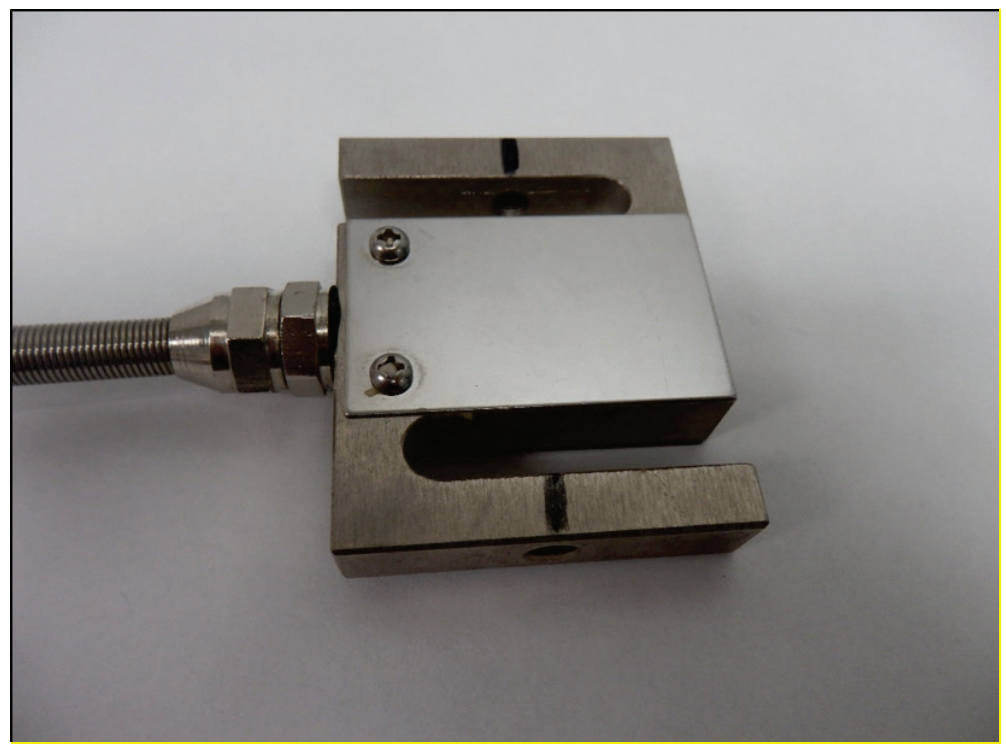

Figure 17. Load cell (hoist load measurement device) - installed.

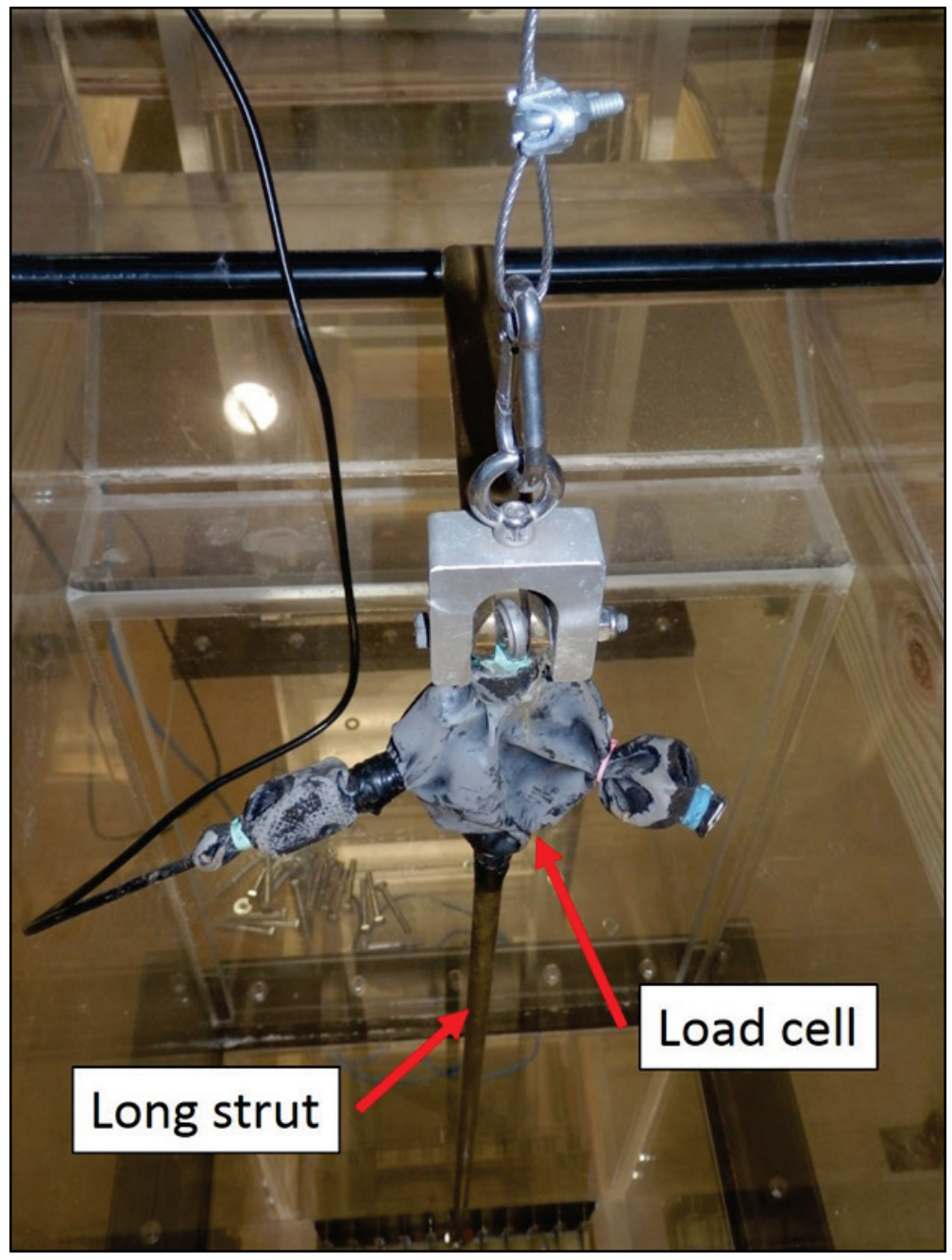


Figure 18. Trunnion load measurement instrument.

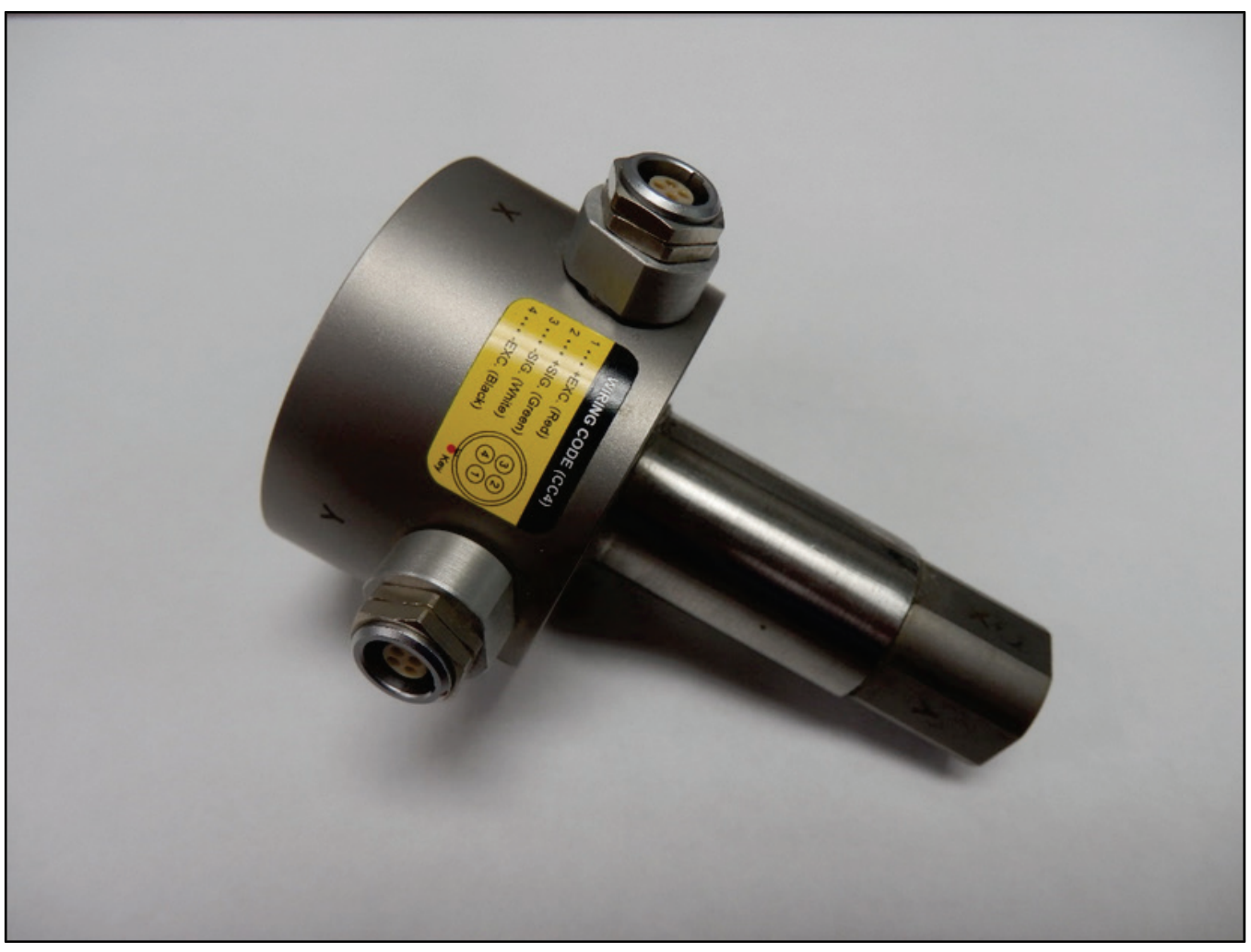

Figure 19. Valve and load arm (trunnion load measurement device) - installed.

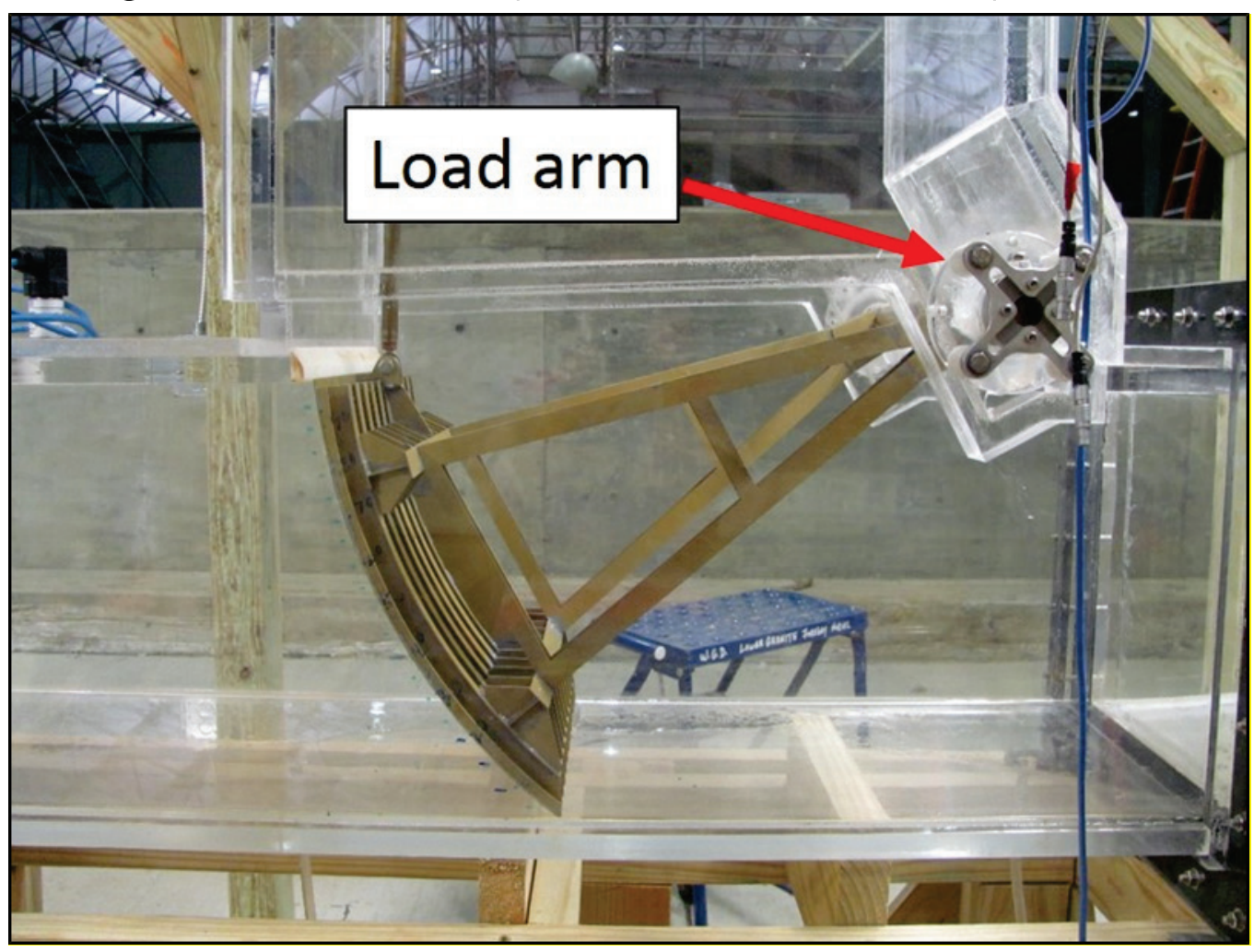




\subsection{Experimental procedures}

\subsubsection{Instrument calibration}

The trunnion's biaxial load arm is calibrated without any water in the model, so the only forces on it are due to the valve's weight. The load arm calibration requires known values of the valve weight supported by the trunnion at two valve positions. These positions can be any two valve positions as long as they are close to each end of the valve motion, which produces a calibration curve that includes much of the range of valve positions that will be tested. Prior to installation in the model culvert, the valve is suspended by cables connected to the trunnion and the lift point at two positions. For each orientation, the tension in each cable is measured. After the valve is installed in the model culvert, it is rotated to one of the previously tested positions. The orientation of the biaxial load arm is adjusted by tightening or loosening the bolts attaching it to the model culvert until the readings match the vertical reaction force values in the pre-installation load testing. The valve is rotated to the second preinstallation position, and the load arm orientation is adjusted until the measured reaction for values match the pre-installation tension value. This process is repeated until the load arm reaction at each position matches the pre-installation tension values without further adjustments. During hydraulic testing, water can leak into the load arm, so dielectric grease and O-ring seals are used in the bushings to prevent the instrument from being damaged by the water in the model. After all data are collected, the model is drained, and the calibration values are confirmed.

\subsubsection{Operation}

Experiments are conducted, with the valve at fixed positions for several steady-flow conditions. Each test simulates the condition occurring at a particular instance during lock operation. The energy grade line, upstream from the valve (Piezometer 1 ) approximately $20 \mathrm{ft}$ above the culvert floor (elevation [el] $33^{1}$ ), is maintained for each test with a manually operated control gate located near the end of the culvert (vertical lift gate shown in Figure 10). This gate regulates the downstream pressure on the valve.

For each valve position, measurements are taken at discharges selected to represent normal prototype operating conditions. At Pickwick Lock, el 410

\footnotetext{
1 All elevations (el) cited herein are in feet above mean sea level, U.S. Lake Survey Datum, 1935 adjustment.
} 
is normal pool elevation for the $51 \mathrm{ft} \mathrm{lift} \mathrm{condition} \mathrm{present} \mathrm{in} \mathrm{January} \mathrm{2017,}$ and el 419 is the maximum normal pool (corresponding to the $59 \mathrm{ft}$ maximum design lift). The lock culvert valve is tested for various valve openings for these operating conditions. The range of valve positions that are tested is shown in Figure 20. A filling valve is represented because the filling valves have less submergence (higher invert) than the emptying valves. Less submergence leads to lower average pressures and larger pressure variations downstream of the valve.

Figure 20. Range of motion for valve testing.

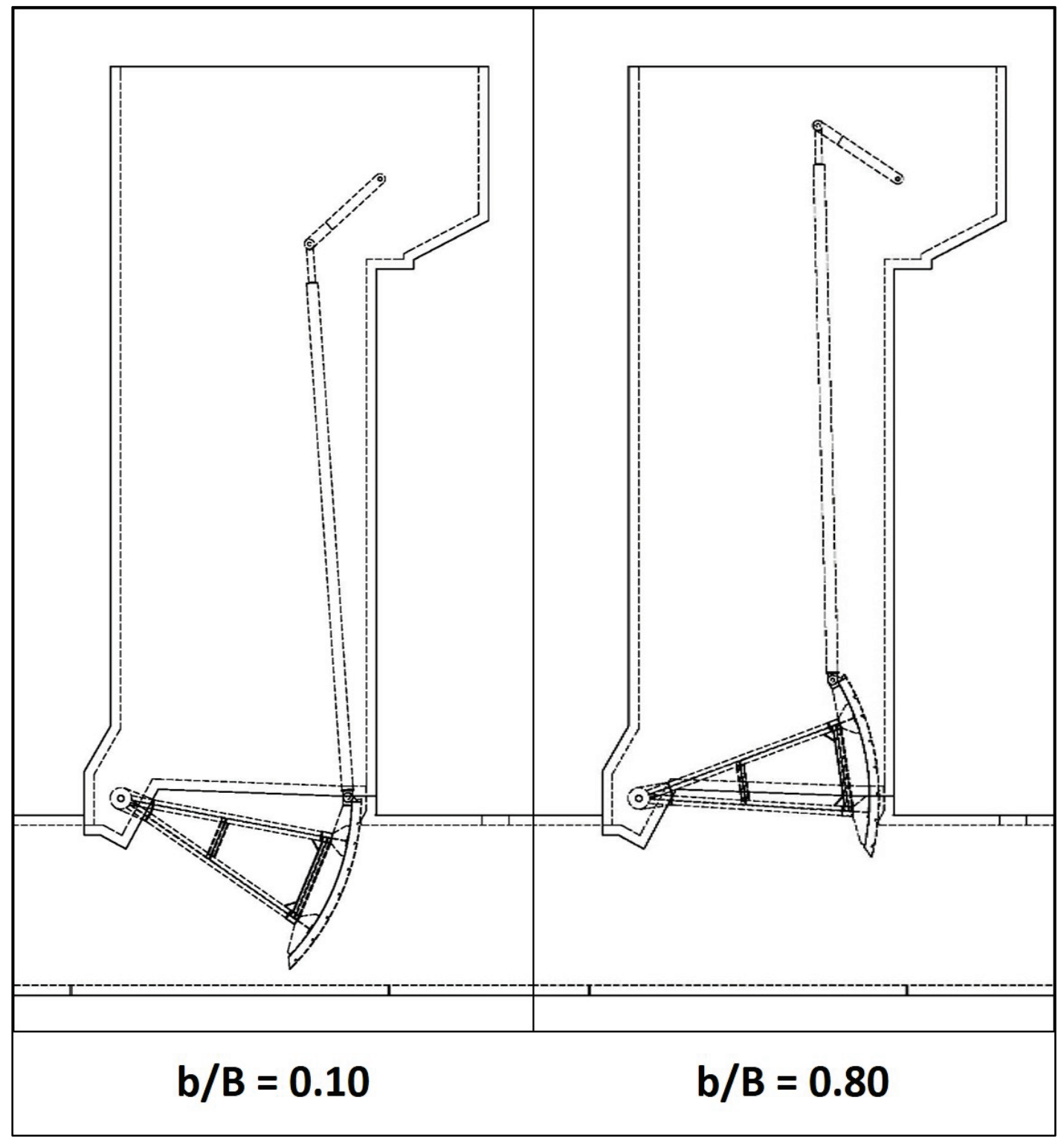


Each experiment consists of three sets of data recording for a continuous 10-minute (min) period (model scale) at $50 \mathrm{~Hz}$. The data that are measured at this frequency include

- the forces in the strut connected to the valve lift point (this force is referred to as the hoist load)

- the vertical and longitudinal (along the length of the culvert) components of the force acting on the trunnion

- the pressure on the culvert roof between the valve skin plate and the downstream bulkhead slot.

Average piezometer elevations are also recorded as part of each experiment.

\subsubsection{Flow conditions}

Experiments are conducted on flow conditions for two separate lock operating lifts: the $59 \mathrm{ft}$ maximum design lift and a $51 \mathrm{ft} \mathrm{lift} \mathrm{that} \mathrm{is} \mathrm{typical}$ of the lock conditions at the time of this study. The $59 \mathrm{ft}$ maximum design lift filling curve was taken from the original Pickwick Lock physical model study report completed by TVA in 1978 for a 4.5 min valve operation. The $51 \mathrm{ft}$ lift filling curve corresponds to conditions measured by Pickwick Lock operators in January 2017. The valve operating time for these measurements is approximately $4.3 \mathrm{~min}$. Discharge curves are developed for each lift. Finally, discharge versus valve position curves are created for each design lift.

A testing plan is developed for each design that is representative of the full range of valve positions during a filling operation. Particular interest is given to lower valve positions. Lock operators at Pickwick Lock note problems with the valve at the beginning of valve operation. The valve positions for testing are $\mathrm{b} / \mathrm{B}=0.10,0.15,0.20,0.25,0.30,0.35,0.40$, $0.50,0.60$, and 0.80 . The filling hydrograph for the $51 \mathrm{ft}$ and $59 \mathrm{ft}$ lifts (shown in Figure 21) and the valve opening schedule are used to calculate the culvert discharges for both lock lifts (shown in Figure 22 and listed in Table 3). The points along each curve represent a valve test position. 
Figure 21. Pickwick Lock filling hydrograph, $51 \mathrm{ft}$ and $59 \mathrm{ft}$ lifts.

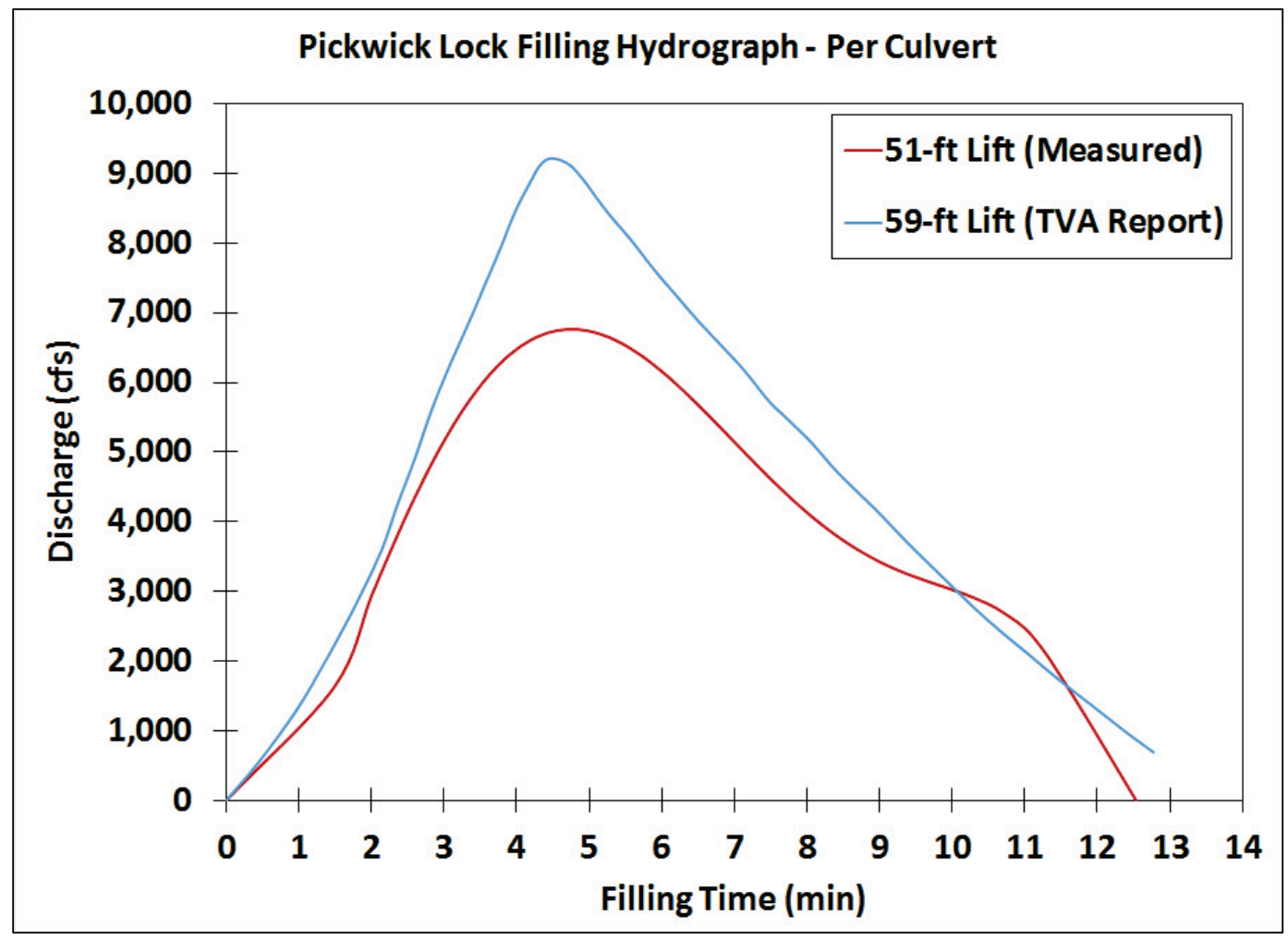

Figure 22. Pickwick discharge curves for physical model experiments $-59 \mathrm{ft}$ and $51 \mathrm{ft} \mathrm{lifts.}$

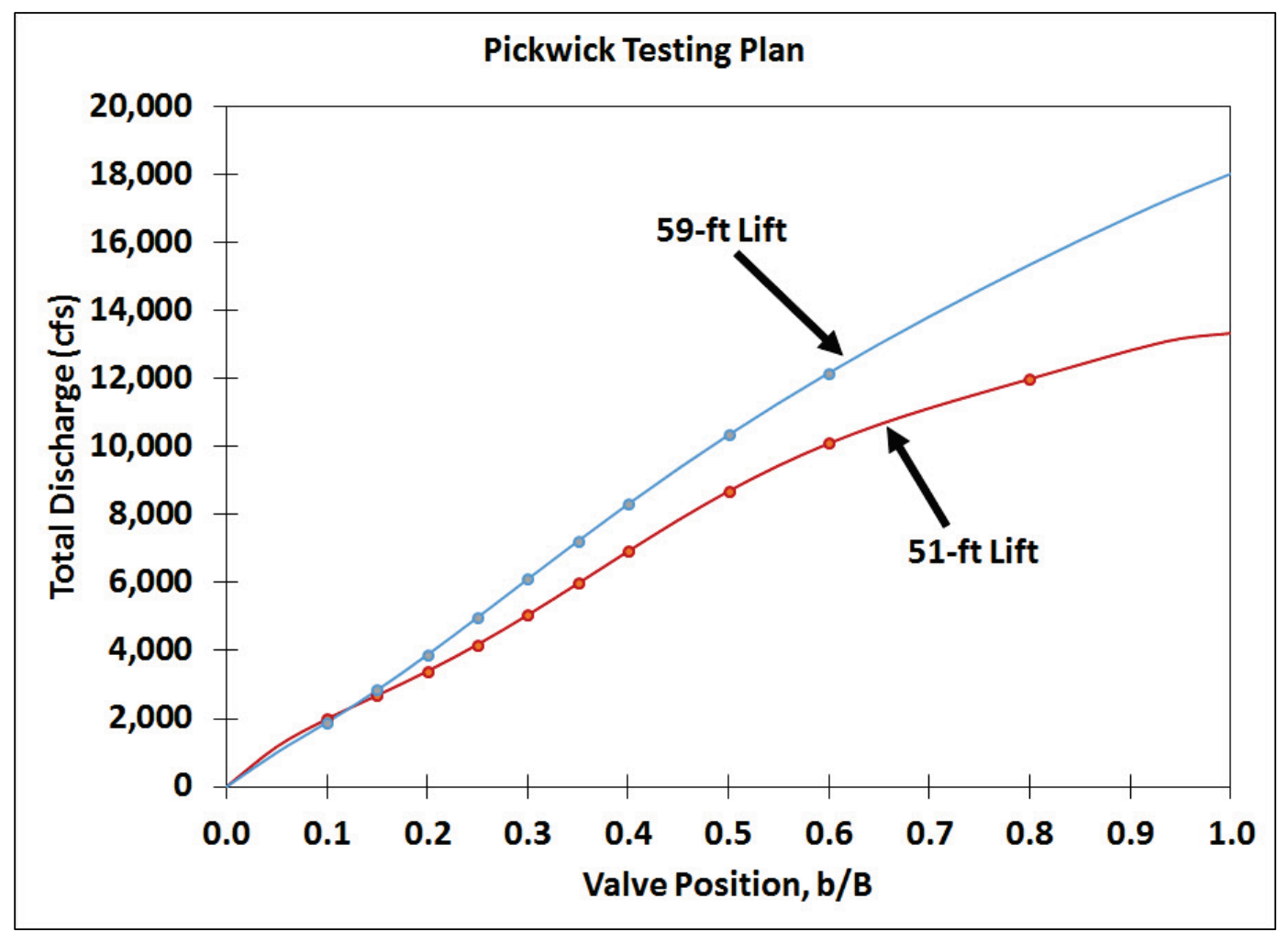


Table 3. Pickwick Culvert discharges in cubic feet per second (cfs) for each valve position, $51 \mathrm{ft}$ and $59 \mathrm{ft}$ lifts.

\begin{tabular}{|l|l|l|l|}
\hline \multirow{2}{*}{ Valve position, b/B } & Valve Opening (ft) & \multicolumn{2}{|l|}{ Culvert Discharge (cfs) } \\
\cline { 3 - 4 } & $\mathbf{5 1} \mathrm{ft}$ Lift & $\mathbf{5 9} \mathrm{ft} \mathrm{Lift}$ \\
\hline 0.10 & 1.50 & 995 & 945 \\
\hline 0.15 & 2.25 & 1,343 & 1,419 \\
\hline 0.20 & 3.00 & 1,698 & 1,938 \\
\hline 0.25 & 3.75 & 2,090 & 2,489 \\
\hline 0.30 & 4.50 & 2,525 & 3,052 \\
\hline 0.35 & 5.25 & 2,989 & 3,612 \\
\hline 0.40 & 6.00 & 3,462 & 4,156 \\
\hline 0.50 & 7.50 & 4,346 & 5,172 \\
\hline 0.60 & 9.00 & 5,049 & 6,086 \\
\hline 0.80 & 12.00 & 5,995 & 7,675 \\
\hline
\end{tabular}

\subsection{Presentation of data}

The valve size and shape are reproduced in brass to represent the steel material of the prototype. While the web and flange widths of the valve structural components (girders, T-beams, etc.) are carefully scaled, the thickness of some members is too thin to scale exactly. For this reason, the model valve weight is not an exact reproduction of the prototype valve weight provided by the LRN. Adding additional weight to make the model valve weight scale exactly to the prototype weight would require modification of the valve's geometry and perhaps a shifting of the valve's center of gravity. Since both the geometry and center of gravity are important parameters, the constructed model valve geometries are not altered. Instead, the reaction loads acting on the valve when water is not in the model are subtracted from all experimental load results. The intent of this study is determining the hydraulic performance of the reverse tainter valves, so the hydraulic effects on the valve are isolated as much as possible. The hoist load and components of the trunnion load with the dry load removed are

$$
\begin{gathered}
P^{\prime}=P_{\text {flow }}-P_{\text {dry }} \\
T_{L}{ }^{\prime}=\left(T_{L}\right)_{\text {flow }}-\left(T_{L}\right)_{d r y} \\
T_{V}{ }^{\prime}=\left(T_{V}\right)_{\text {flow }}-\left(T_{V}\right)_{\text {dry }}
\end{gathered}
$$




$$
T^{\prime}=\sqrt{\left(T_{V}{ }^{\prime}\right)^{2}+\left(T_{L}{ }^{\prime}\right)^{2}}
$$

where the subscript "flow" denotes values that are directly measured during the experiments with flow and the subscript "dry" denotes values that are measured when no water is in the model culvert.

The hydraulic force equations updated with the dry-load independent quantities are

$$
\begin{gathered}
H_{L}=P^{\prime} \sin \alpha+T_{L}{ }^{\prime} \\
H_{V}=W-P^{\prime} \cos \alpha-T_{V}{ }^{\prime}
\end{gathered}
$$

The reaction loads, and hydraulic loads that derive from them, are accurate and can be scaled to useful prototype values because the valve geometry and flow patterns near the valve are also accurately represented (kinematic similitude).

The quantities calculated using Equations 19-24 during the valve experiments are presented in Chapter 4. 


\section{Experimental Results}

In this chapter, a description of each valve and the results of the experiments are presented. A section discusses the existing valve, and a section discusses the modified valve. The valve descriptions are limited to the hydraulically significant geometric aspects, and the model results include measured and calculated quantities. The forces acting on the valve - hoist, trunnion, and hydraulic - are presented in a series of tables with corresponding plots in the appendices. Each table includes the mean, maximum, and minimum load at prototype scale for each valve position tested. Each set of results is obtained from three sets of valve experiments. The average, maximum, and minimum value measured/calculated for each quantity are calculated for each experiment. Then, the average, maximum, and minimum values of the quantities for each test (average of averages, maximum of maxima, minimum of minima) are calculated. Those values are presented in this report. The quantities in this chapter are calculated using Equations 19-24.

In addition to the plots of each set of experimental results shown in Appendices A and B, further data that compare the relative performance of the valves are shown in Appendix $\mathrm{C}$ and are discussed in Chapter 5.

\subsection{Existing valve}

\subsubsection{Valve description - existing valve}

The existing Pickwick Lock culvert valve is shown in Figure 23 (line drawing) and Figure 24 (photograph). All components of this openframed tainter valve are exposed to the water while in service. The vertical main ribs provide the structural strength to the valve, with a series of smaller members extending horizontally along the skin plate. Therefore, the valve is a vertically framed valve. In this report, these horizontal members are referred to as skin plate stiffeners. The arms that connect the skin plate to the trunnion are connected to the trunnion ends but taper slightly inward before attaching to the skin plate. The bottom tip of the valve is tapered to a sharp point, which promotes flow separation at that point, reducing vibration. 
Figure 23. Existing Pickwick Lock culvert valve geometry - 4-view.
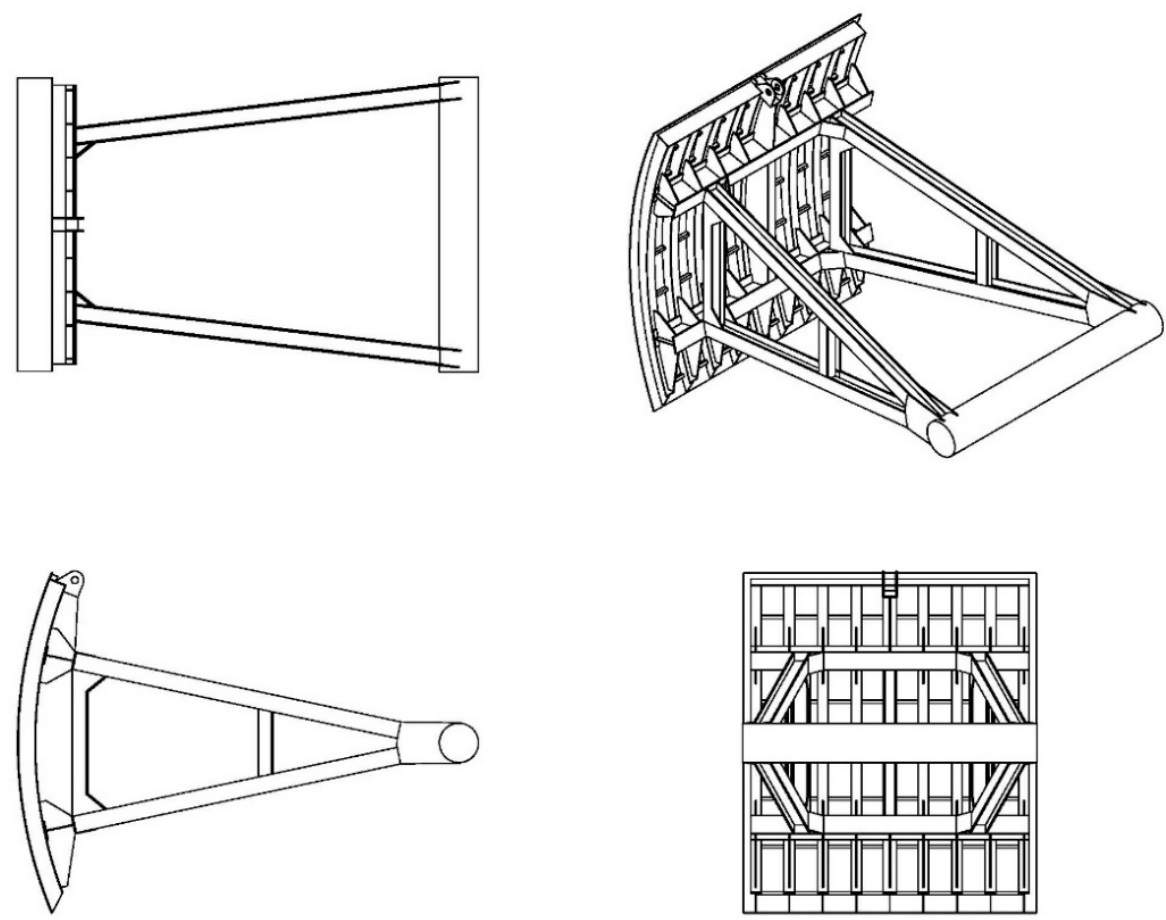

Figure 24. Model valve - existing design.

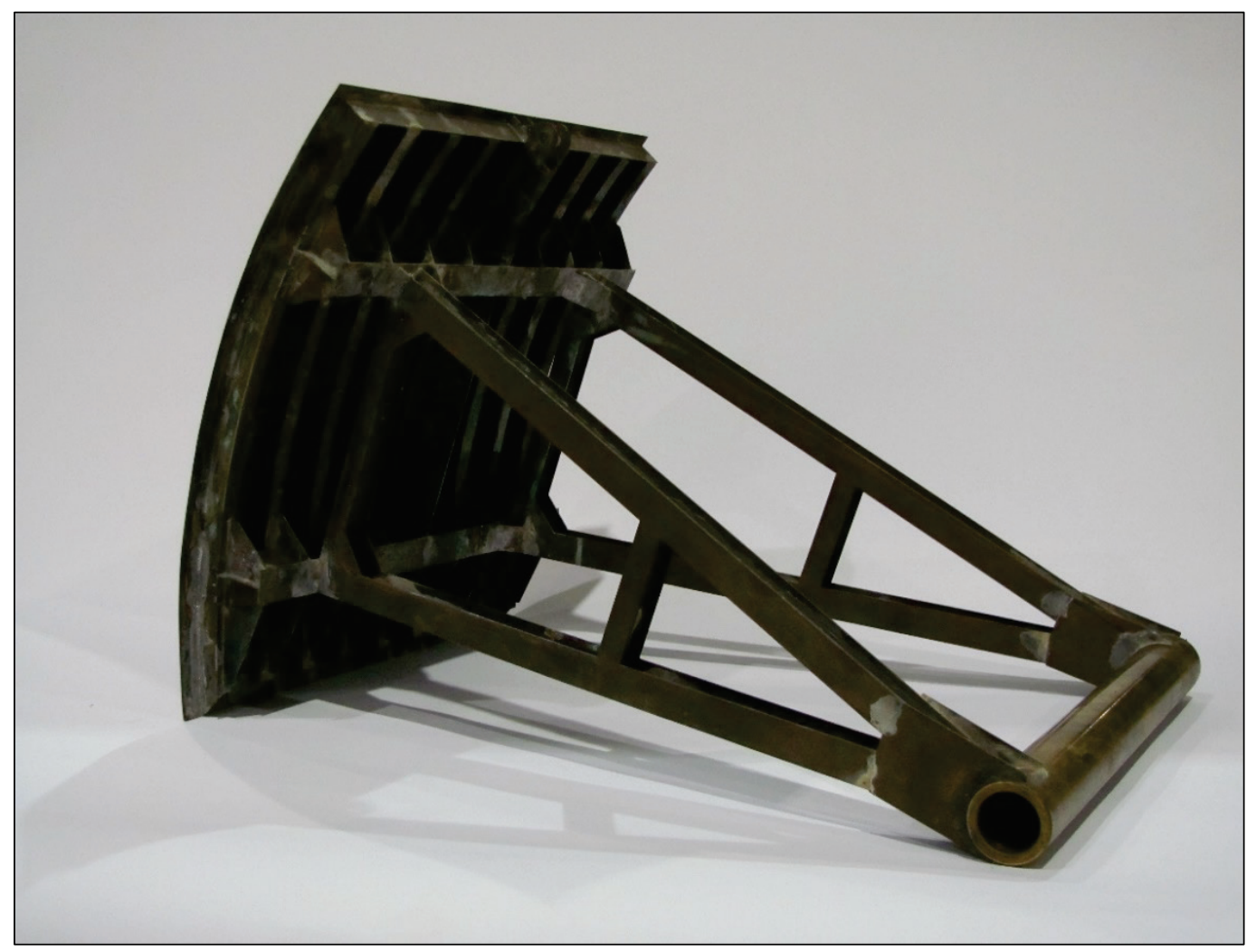




\subsubsection{Flow behavior - existing design}

Experiments are attempted for each flow condition shown in Figure 22. However, setting up the proper flow conditions for the $51 \mathrm{ft}$ lift at valve positions $\mathrm{b} / \mathrm{B}=0.25$ and $\mathrm{b} / \mathrm{B}=0.30$ are unsuccessful. All attempts at setting the correct flow rate and upstream pressure causes the flow immediately upstream of the vertical lift gate to become free-surface. Attempts to bleed the air from the culvert are also unsuccessful. The same flow behavior exists for the $59 \mathrm{ft}$ lift at valve positions $\mathrm{b} / \mathrm{B}=0.25$ and b/B $=0.30$, so these positions are also removed from the test plan. The discharge for $\mathrm{b} / \mathrm{B}=0.80$ exceeds the capacity of the valve test facility, so this valve position is removed from the $59 \mathrm{ft}$ test plan.

Flow near the existing valve is qualitatively similar to flow near reverse tainter valves in studies of other navigation locks. The flow is observed with dye released from multiple vertical positions within the culvert upstream of the valve. Figure 25 shows the dye path as it approaches the valve for experiment condition, $\mathrm{b} / \mathrm{B}=0.10$. The dye patterns show that the majority of the flow accelerates underneath the valve, with some flow traveling more slowly upward into the valve well. Some flow in the valve well is directed through the gap between the downstream side of the skin plate and the downstream wall of the valve well. A large vertical eddy forms immediately downstream of the valve.

One aspect of the flow near the valve that is different from the flows in other lock culverts occurs near the downstream bulkhead slot at valve positions of $\mathrm{b} / \mathrm{B} \geq 0.5 \mathrm{O}$. Throughout each experiment for those valve positions, the water surface fluctuates rapidly in the downstream bulkhead slot by as much as $15 \mathrm{ft}$ (at prototype scale) throughout each experiment. This flow behavior is shown Figure 26 and Figure 27. The water surface movement indicates strong pressure fluctuations downstream of the valve that extend past the downstream bulkhead slot. The rapid water surface motion at the downstream bulkhead slot coincides with significant valve vibration. The valve can easily be seen vibrating throughout the higher valve position experiments. One possible cause for this occurrence is the resonant pressure effects due to the interaction of the jet expansion downstream of the valve tip for this valve position with the downstream bulkhead slot. At lower valve positions, the downstream bulkhead slot water surface elevation varies much less rapidly and remains fairly level throughout testing. Also, at these lower valve positions, significant valve vibration is not present. This sloshing does not allow the water surface in the downstream bulkhead slot 
to fall below the culvert roof during testing, but the potential is present. If the water surface does drop below the culvert soffit, air entering the culvert could cause cavitation.

Figure 25. Dye released upstream of the existing valve, $b / B=0.10$.

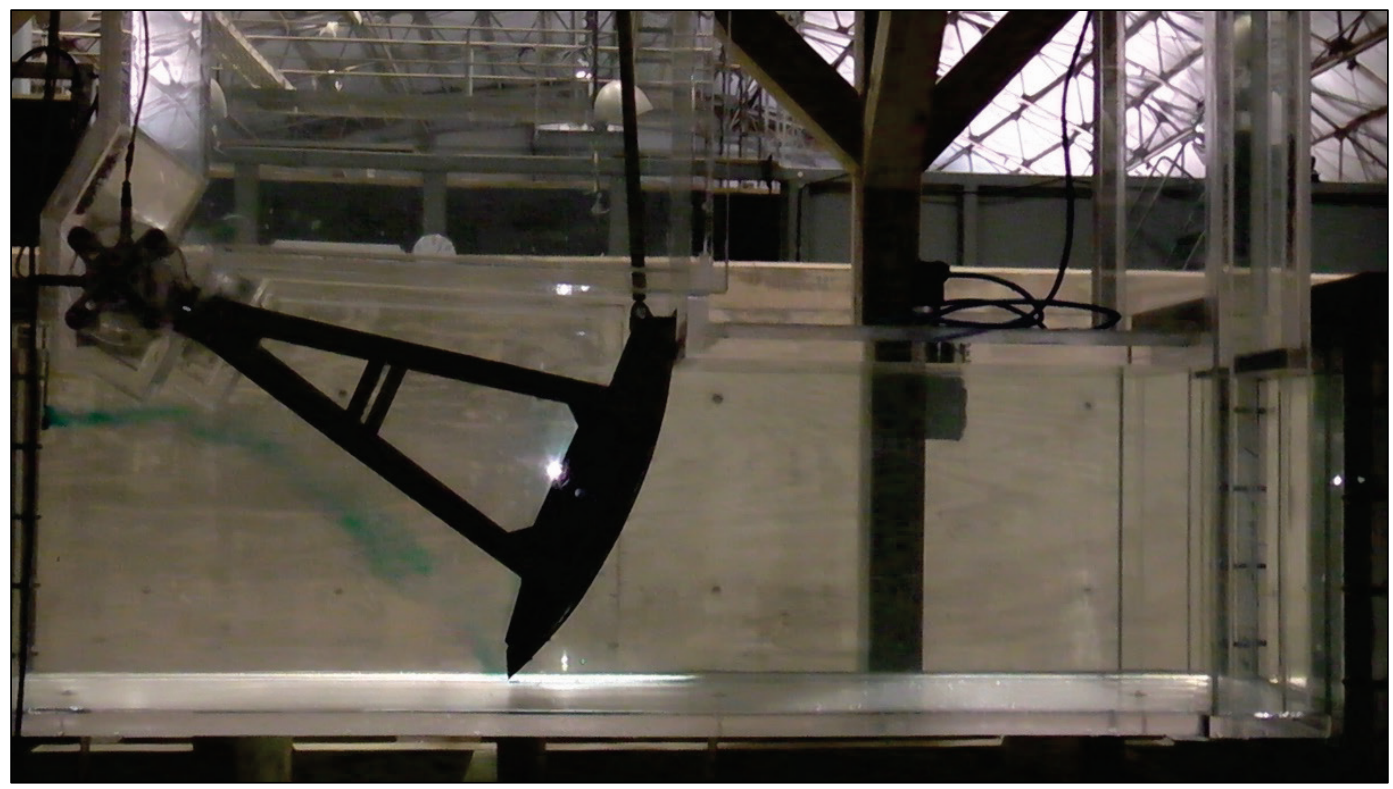

Figure 26. Existing valve at $b / B=0.20-$ downstream bulkhead slot flow.

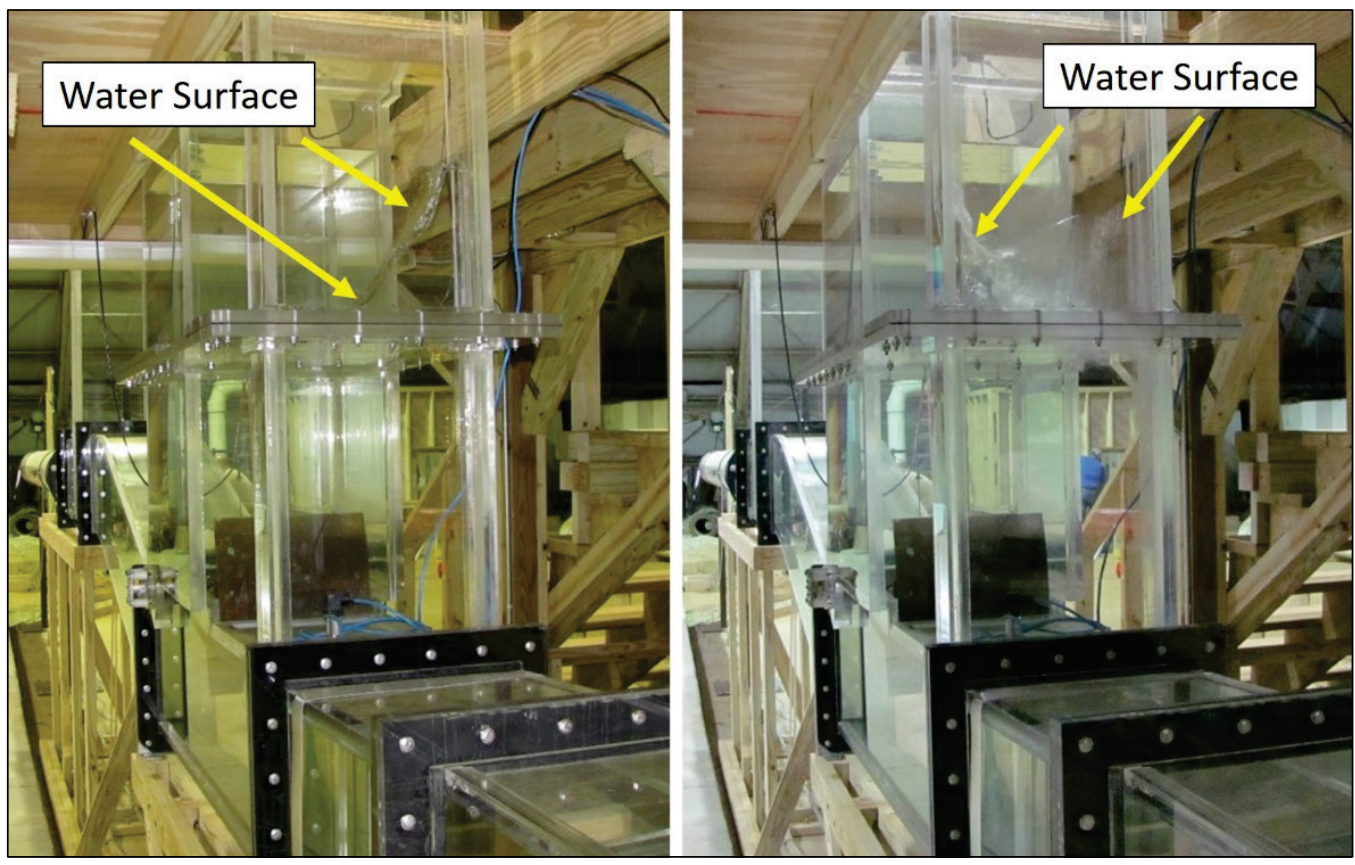


Figure 27. Existing valve at $b / B=0.60-$ downstream bulkhead slot flow.

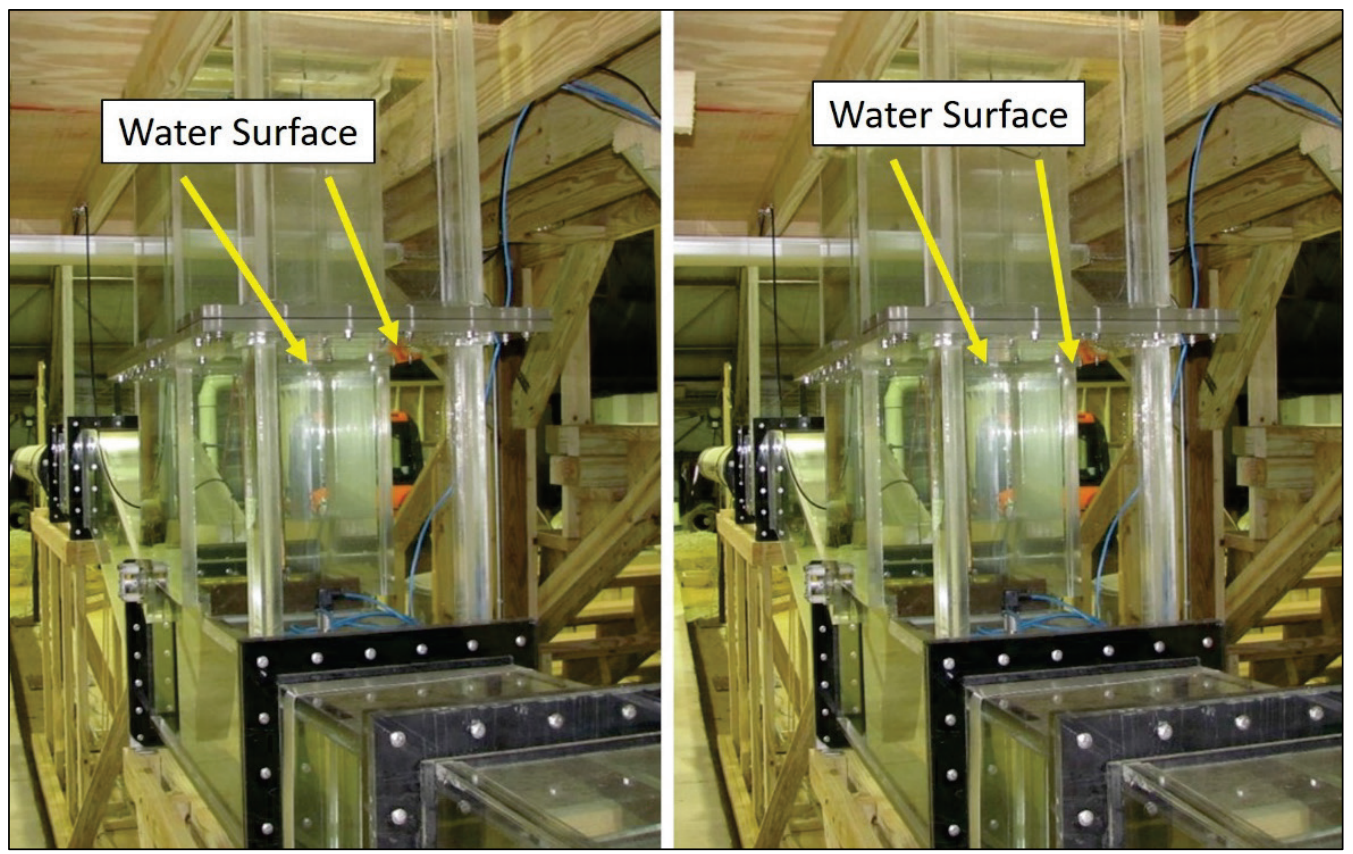

\subsubsection{Load results - existing valve}

The model results for the existing Pickwick Lock culvert valve provide a baseline for comparison of the modified model valve results. Each load is presented for each lift ratio before proceeding to another quantity. The order of these tests is intended to highlight the differences in valve performance from changes in the lift and the culvert discharge. The mean loads are the focus of this section. Tables of these values are provided in this section. The maximum and minimum load values, which are used for prototype design calculations, follow essentially the same trends as the mean values. Tables of the mean, maximum, and minimum loads for the existing valve are included to provide information from the model results for use in prototype design. Plots of the same values are provided in Appendix A.

\subsubsection{Hoist loads}

The existing valve hoist loads are listed in Table 4. The dry load is removed from these values (Equation 19). The hoist load decreases during valve opening. For the $51 \mathrm{ft}$ lift, the mean hoist load's range is from 12.4 kips in tension ( $\mathrm{at} \mathrm{b} / \mathrm{B}=0.20$ ) to $3.9 \mathrm{kips}$ in compression (at $\mathrm{b} / \mathrm{B}=0.60),(1 \mathrm{kip}=1,000$ pounds $)$. For the $59 \mathrm{ft}$ lift, the mean hoist load extends from $10.8 \mathrm{kips}(\mathrm{at} \mathrm{b} / \mathrm{B}=0.20$ ) to $5.9 \mathrm{kips}$ in compression (at $\mathrm{b} / \mathrm{B}=0.5 \mathrm{O}$ ). For both lifts, the hoist load decreases rather linearly 
until $\mathrm{b} / \mathrm{B}=0.35$ then remains fairly constant throughout the remainder of the opening. Plots of the values shown in Table 4 are included in Appendix A.

Table 4. Existing valve hoist loads, $51 \mathrm{ft}$ and $59 \mathrm{ft}$ lifts.

\begin{tabular}{|c|c|c|c|c|c|c|c|}
\hline \multirow{3}{*}{$\begin{array}{c}\text { Valve } \\
\text { Position, } \\
\text { b/B }\end{array}$} & \multirow{3}{*}{$\begin{array}{l}\text { Valve } \\
\text { Position } \\
\text { (ft) }\end{array}$} & \multicolumn{6}{|c|}{ Hoist Load (kips) } \\
\hline & & \multicolumn{3}{|c|}{$51 \mathrm{ft} \mathrm{Lift}$} & \multicolumn{3}{|c|}{$59 \mathrm{ft}$ Lift } \\
\hline & & Mean & Max & Min & Mean & Max & Min \\
\hline 0.10 & 1.50 & - & - & - & 9.5 & 17.0 & 0.0 \\
\hline 0.15 & 2.25 & 11.7 & 19.7 & 1.3 & 6.2 & 19.9 & -6.5 \\
\hline 0.20 & 3.00 & 12.4 & 21.4 & 1.0 & 10.8 & 24.7 & -0.7 \\
\hline 0.25 & 3.75 & 7.5 & 20.6 & -5.6 & - & - & - \\
\hline 0.30 & 4.50 & 1.8 & 9.3 & -5.9 & - & - & - \\
\hline 0.35 & 5.25 & -1.6 & 6.2 & -11.8 & 3.9 & 19.4 & -10.8 \\
\hline 0.40 & 6.00 & -0.3 & 8.0 & -9.7 & -0.8 & 10.1 & -11.0 \\
\hline 0.50 & 7.50 & -2.4 & 8.0 & -13.0 & -5.9 & 3.5 & -20.7 \\
\hline 0.60 & 9.00 & -3.9 & 7.5 & -17.9 & -5.7 & 8.9 & -26.1 \\
\hline 0.80 & 12.00 & -3.7 & 7.9 & -17.5 & - & - & - \\
\hline
\end{tabular}

\subsubsection{Trunnion loads}

The existing valve trunnion loads, as defined in Figure 8 and Equations 20-22, are listed in Table 5 and Table 6 . The vertical trunnion load decreases (generally linearly) throughout the opening of the valve. For the $51 \mathrm{ft}$ lift, the mean vertical trunnion load extends from $94.7 \mathrm{kips}$ (at b/B = 0.15 ) to $3.8 \mathrm{kips}(\mathrm{at} \mathrm{b} / \mathrm{B}=0.80$ ). The $59 \mathrm{ft}$ lift produces a mean vertical trunnion load range of $101.5 \mathrm{kips}$ (at $\mathrm{b} / \mathrm{B}=0.10$ ) to $33.9 \mathrm{kips}$ (at $\mathrm{b} / \mathrm{B}=$ $0.60)$. For the $51 \mathrm{ft}$ lift, the mean longitudinal trunnion loads extend from 143.4 kips (at b/B $=0.15$ ) to $10.6 \mathrm{kip}(\mathrm{at} \mathrm{b} / \mathrm{B}=0.80$ ). For the $59 \mathrm{ft}$ lift, mean longitudinal trunnion load varies between $157.8 \mathrm{kips}(\mathrm{at} \mathrm{b} / \mathrm{B}=0.15)$ to $85.1 \mathrm{kips}(\mathrm{at} \mathrm{b} / \mathrm{B}=0.60$ ). The mean resultant trunnion loads for the $51 \mathrm{ft}$ lift range from $171.9 \mathrm{kips}(\mathrm{at} \mathrm{b} / \mathrm{B}=0.15$ ) to $11.5 \mathrm{kips}(\mathrm{at} \mathrm{b} / \mathrm{B}=0.80$ ). For the $59 \mathrm{ft}$ lift, the mean resultant trunnion load range is $186.6 \mathrm{kips}$ (at $\mathrm{b} / \mathrm{B}=0.15)$ to 70.2 kips $(\mathrm{at} \mathrm{b} / \mathrm{B}=0.60)$. Plots of the experimental results are included in Appendix A. 
Table 5. Existing valve trunnion loads $-51 \mathrm{ft} \mathrm{lift}$.

\begin{tabular}{|c|c|c|c|c|c|c|c|c|c|c|}
\hline \multirow{2}{*}{$\begin{array}{l}\text { Valve } \\
\text { Position } \\
\text { b/B }\end{array}$} & \multirow{2}{*}{$\begin{array}{l}\text { Valve } \\
\text { Position } \\
\text { (ft) }\end{array}$} & \multicolumn{3}{|c|}{$\begin{array}{l}\text { Vertical Trunnion Load } \\
\text { (kips) }\end{array}$} & \multicolumn{3}{|c|}{$\begin{array}{l}\text { Longitudinal Trunnion } \\
\text { Load (kips) }\end{array}$} & \multicolumn{3}{|c|}{$\begin{array}{l}\text { Resultant Trunnion } \\
\text { Load (kips) }\end{array}$} \\
\hline & & Mean & Max & Min & Mean & Max & Min & Mean & Max & Min \\
\hline 0.15 & 2.25 & 94.7 & 103.3 & 85.8 & 143.4 & 166.1 & 130.9 & 171.9 & 195.6 & 157.3 \\
\hline 0.20 & 3.00 & 71.4 & 80.0 & 62.4 & 105.9 & 116.4 & 94.4 & 127.7 & 140.4 & 114.8 \\
\hline 0.25 & 3.75 & 66.6 & 74.2 & 56.6 & 108.5 & 123.8 & 94.5 & 127.3 & 144.3 & 110.1 \\
\hline 0.30 & 4.50 & 58.7 & 71.2 & 46.3 & 114.1 & 135.4 & 94.4 & 128.4 & 148.5 & 107.9 \\
\hline 0.35 & 5.25 & 54.8 & 61.1 & 46.4 & 114.7 & 135.6 & 91.6 & 127.2 & 148.7 & 103.3 \\
\hline 0.40 & 6.00 & 44.1 & 52.3 & 33.3 & 94.8 & 118.0 & 65.2 & 104.7 & 127.9 & 74.5 \\
\hline 0.50 & 7.50 & 29.9 & 40.8 & 18.8 & 74.9 & 101.7 & 47.5 & 80.6 & 109.1 & 52.2 \\
\hline 0.60 & 9.00 & 18.8 & 30.5 & 7.0 & 53.0 & 85.6 & 21.1 & 56.3 & 89.0 & 24.0 \\
\hline 0.80 & 12.00 & 3.8 & 12.0 & -5.6 & 10.6 & 23.7 & -5.6 & 11.5 & 26.6 & 0.4 \\
\hline
\end{tabular}

Table 6. Existing valve trunnion loads $-59 \mathrm{ft} \mathrm{lift.}$

\begin{tabular}{|c|c|c|c|c|c|c|c|c|c|c|}
\hline \multirow{2}{*}{$\begin{array}{c}\text { Valve } \\
\text { Position }\end{array}$} & \multirow{2}{*}{$\begin{array}{c}\text { Valve } \\
\text { Position } \\
\text { b/B }\end{array}$} & \multicolumn{3}{|c|}{$\begin{array}{c}\text { Vertical Trunnion Load } \\
\text { (kips) }\end{array}$} & \multicolumn{3}{|c|}{$\begin{array}{c}\text { Longitudinal Trunnion } \\
\text { Load (kips) }\end{array}$} & \multicolumn{3}{|c|}{$\begin{array}{c}\text { Resultant Trunnion } \\
\text { Load (kips) }\end{array}$} \\
\cline { 5 - 13 } & Mean & Max & Min & Mean & Max & Min & Mean & Max & Min \\
\hline 0.10 & 1.50 & 101.5 & 112.1 & 90.1 & 156.0 & 170.3 & 138.1 & 186.1 & 203.1 & 166.5 \\
\hline 0.15 & 2.25 & 99.7 & 107.7 & 90.1 & 157.8 & 172.0 & 144.1 & 186.6 & 202.9 & 172.8 \\
\hline 0.20 & 3.00 & 91.6 & 104.9 & 78.6 & 143.2 & 163.3 & 119.3 & 170.1 & 192.1 & 143.7 \\
\hline 0.25 & 3.75 & - & - & - & - & - & - & - & - & - \\
\hline 0.30 & 4.50 & - & - & - & - & - & - & - & - & - \\
\hline 0.35 & 5.25 & 71.6 & 80.1 & 61.1 & 137.3 & 157.5 & 122.4 & 154.9 & 176.7 & 136.8 \\
\hline 0.40 & 6.00 & 59.5 & 74.3 & 45.0 & 128.0 & 151.7 & 104.8 & 141.2 & 168.2 & 116.5 \\
\hline 0.50 & 7.50 & 43.3 & 54.0 & 30.5 & 91.7 & 132.5 & 59.2 & 101.5 & 143.1 & 68.0 \\
\hline 0.60 & 9.00 & 33.9 & 46.6 & 14.4 & 85.1 & 114.9 & 21.1 & 70.2 & 121.9 & 28.4 \\
\hline
\end{tabular}

\subsubsection{Trunnion end loads}

The load that each trunnion end is subjected to is half of the total trunnion loads listed in the previous section. The trunnion end loads for the existing valve are listed in Table 7 and Table 8. The vertical trunnion end load decreases (generally linearly) throughout the valve opening. For the $51 \mathrm{ft}$ lift, the mean vertical trunnion end load extends from $47.4 \mathrm{kips}$ (at b/B = 0.15 ) to $1.9 \mathrm{kips}(\mathrm{at} \mathrm{b} / \mathrm{B}=0.80$ ). The $59 \mathrm{ft}$ lift produces a mean vertical trunnion end load range of $50.7 \mathrm{kips}(\mathrm{at} \mathrm{b} / \mathrm{B}=0.10)$ to $17.0 \mathrm{kips}(\mathrm{at} \mathrm{b} / \mathrm{B}=$ 
o.60). The longitudinal trunnion end loads are much larger than the vertical trunnion end loads, and both end loads decrease (generally not linearly) throughout the valve opening. For the $51 \mathrm{ft}$ lift, the mean longitudinal trunnion end load extends from $71.7 \mathrm{kips}(\mathrm{at} \mathrm{b} / \mathrm{B}=0.15)$ to 5.3 kips ( $\mathrm{at} \mathrm{b} / \mathrm{B}=0.80$ ). The mean longitudinal trunnion end loads for the $59 \mathrm{ft}$ lift vary between $78.9 \mathrm{kips}(\mathrm{at} \mathrm{b} / \mathrm{B}=0.15)$ and $42.5 \mathrm{kips}(\mathrm{at} \mathrm{b} / \mathrm{B}=$ o.60). The mean resultant trunnion end loads for the $51 \mathrm{ft}$ lift range from 86.0 kips (at b/B $=0.15$ ) to $5.8 \mathrm{kips}(\mathrm{at} \mathrm{b} / \mathrm{B}=0.80$ ). For the $59 \mathrm{ft}$ lift, the mean resultant trunnion end load range is $93.3 \mathrm{kips}(\mathrm{at} \mathrm{b} / \mathrm{B}=0.15$ ) to 35.1 kips $(\mathrm{at} \mathrm{b} / \mathrm{B}=0.60)$. Plots of the experimental results are included in Appendix A.

Table 7. Existing valve trunnion end loads $-51 \mathrm{ft}$ lift.

\begin{tabular}{|c|c|c|c|c|c|c|c|c|c|c|}
\hline \multirow{2}{*}{$\begin{array}{c}\text { Valve } \\
\text { Position } \\
\text { b/B }\end{array}$} & $\begin{array}{c}\text { Valve } \\
\text { Position } \\
(\mathrm{ft})\end{array}$ & \multicolumn{2}{|c|}{$\begin{array}{c}\text { Vertical Trunnion End } \\
\text { Load (kips) }\end{array}$} & \multicolumn{2}{|c|}{$\begin{array}{c}\text { Longitudinal Trunnion } \\
\text { End Load (kips) }\end{array}$} & \multicolumn{3}{|c|}{$\begin{array}{c}\text { Resultant Trunnion End } \\
\text { Load (kips) }\end{array}$} \\
\cline { 5 - 12 } & Mean & Max & Min & Mean & Max & Min & Mean & Max & Min \\
\hline 0.15 & 2.25 & 47.4 & 51.7 & 42.9 & 71.7 & 83.1 & 65.5 & 86.0 & 97.8 & 78.7 \\
\hline 0.20 & 3.00 & 35.7 & 40.0 & 31.2 & 52.9 & 58.2 & 47.2 & 63.9 & 70.2 & 57.4 \\
\hline 0.25 & 3.75 & 33.3 & 37.1 & 28.3 & 54.2 & 61.9 & 47.2 & 63.6 & 72.1 & 55.1 \\
\hline 0.30 & 4.50 & 29.4 & 35.6 & 23.2 & 57.1 & 67.7 & 47.2 & 64.2 & 74.3 & 53.9 \\
\hline 0.35 & 5.25 & 27.4 & 30.5 & 23.2 & 57.3 & 67.8 & 45.8 & 63.6 & 74.3 & 51.7 \\
\hline 0.40 & 6.00 & 22.0 & 26.2 & 16.6 & 47.4 & 59.0 & 32.6 & 52.3 & 63.9 & 37.2 \\
\hline 0.50 & 7.50 & 14.9 & 20.4 & 9.4 & 37.4 & 50.9 & 23.7 & 40.3 & 54.5 & 26.1 \\
\hline 0.60 & 9.00 & 9.4 & 15.2 & 3.5 & 26.5 & 42.8 & 10.5 & 28.1 & 44.5 & 12.0 \\
\hline 0.80 & 12.00 & 1.9 & 6.0 & -2.8 & 5.3 & 11.9 & -2.8 & 5.8 & 13.3 & 0.2 \\
\hline
\end{tabular}


Table 8. Existing valve trunnion end loads $-59 \mathrm{ft}$ lift.

\begin{tabular}{|c|c|c|c|c|c|c|c|c|c|c|}
\hline \multirow{2}{*}{$\begin{array}{c}\text { Valve } \\
\text { Position } \\
\text { b/B }\end{array}$} & $\begin{array}{c}\text { Valve } \\
\text { Position } \\
\text { (ft) }\end{array}$ & \multicolumn{2}{|c|}{$\begin{array}{c}\text { Vertical Trunnion End } \\
\text { Load (kips) }\end{array}$} & \multicolumn{2}{|c|}{$\begin{array}{c}\text { Longitudinal Trunnion } \\
\text { End Load (kips) }\end{array}$} & \multicolumn{3}{|c|}{$\begin{array}{c}\text { Resultant Trunnion End } \\
\text { Load (kips) }\end{array}$} \\
\hline 0.10 & 1.50 & 50.7 & 56.0 & 45.0 & 78.0 & 85.2 & 69.0 & 93.1 & 101.5 & 83.2 \\
\hline 0.15 & 2.25 & 49.8 & 53.9 & 45.1 & 78.9 & 86.0 & 72.1 & 93.3 & 101.5 & 86.4 \\
\hline 0.20 & 3.00 & 45.8 & 52.5 & 39.3 & 71.6 & 81.6 & 59.7 & 85.0 & 96.0 & 71.8 \\
\hline 0.25 & 3.75 & - & - & - & - & - & - & - & - & - \\
\hline 0.30 & 4.50 & - & - & - & - & - & - & - & - & - \\
\hline 0.35 & 5.25 & 35.8 & 40.1 & 30.5 & 68.7 & 78.8 & 61.2 & 77.5 & 88.4 & 68.4 \\
\hline 0.40 & 6.00 & 29.7 & 37.2 & 22.5 & 64.0 & 75.8 & 52.4 & 70.6 & 84.1 & 58.2 \\
\hline 0.50 & 7.50 & 21.7 & 27.0 & 15.3 & 45.9 & 66.3 & 29.6 & 50.8 & 71.5 & 34.0 \\
\hline 0.60 & 9.00 & 17.0 & 23.3 & 7.2 & 42.5 & 57.4 & 10.5 & 35.1 & 60.9 & 14.2 \\
\hline
\end{tabular}

\subsubsection{Hydraulic loads}

The hydraulic loads acting on the existing valve are listed in Table 9 and Table 10. Plots of these values are included in Appendix A. The values are calculated using Equations 6, 23, and 24. Over the entire valve opening for both lifts, the vertical hydraulic load increases rather linearly. For the $51 \mathrm{ft}$ lift, the mean vertical hydraulic load goes from 37.8 kips of uplift (at $b / B=$ 0.80 ) to $68.4 \mathrm{kips}$ of downpull (at b/B = 0.15). For the $59 \mathrm{ft}$ lift, the mean vertical hydraulic force varies between 73.0 kips of downpull (at $b / \mathrm{B}=$ 0.10 ) and $9.7 \mathrm{kips}$ of uplift ( $\mathrm{at} \mathrm{b} / \mathrm{B}=0.60$ ). These loads decrease during the valve opening and show a drastic decrease above $b / \mathrm{B}=0.35$. The vertical hydraulic load changes from negative to positive as the valve opens for both lifts (between $\mathrm{b} / \mathrm{B}=0.40$ and $\mathrm{b} / \mathrm{B}=0.50$ ). This change indicates that the hydraulic force acting on the valve changes from downpull to uplift as the valve is raised. This behavior is caused by the combination of the flow as it is directed along the skin plate and the valve vertical projection of the upstream side of the skin plate. At low valve positions, the opening under the valve is small, so the approach flow must turn dramatically downward, which produces the high downpull force on the valve. As the opening under the valve increases, the approach flow no longer turns so dramatically to pass underneath the valve.

For the $51 \mathrm{ft}$ lift, the mean longitudinal hydraulic load ranges from 144.4 kips ( $\mathrm{at} \mathrm{b} / \mathrm{B}=0.15$ ) to $10.5 \mathrm{kips}(\mathrm{at} \mathrm{b} / \mathrm{B}=0.80$ ). For the $59 \mathrm{ft}$ lift, the mean longitudinal hydraulic load varies between $158.3 \mathrm{kips}(\mathrm{at} \mathrm{b} / \mathrm{B}=0.15)$ and 
60.3 kips (at $\mathrm{b} / \mathrm{B}=0.60$ ). For the $51 \mathrm{ft}$ lift, the mean resultant hydraulic load range is $159.8 \mathrm{kips}$ ( $\mathrm{at} \mathrm{b} / \mathrm{B}=0.15$ ) to $39.5 \mathrm{kips}$ ( $\mathrm{at} \mathrm{b} / \mathrm{B}=0.80$ ). For the $59 \mathrm{ft}$ lift, the mean resultant hydraulic load varies between $172.9 \mathrm{kips}$ $(\mathrm{at} \mathrm{b} / \mathrm{B}=0.10$ ) and 62.0 kips ( $\mathrm{at} \mathrm{b} / \mathrm{B}=0.60)$. The reduction in the longitudinal hydraulic load as the valve is opened is caused by a combination of two consequences of the geometry layout. First, at low valve positions, the flow must turn more to pass underneath the valve tip than at higher valve positions. Second, as the valve is opened the valve moves farther into the valve well, so the horizontal projection of the skin plate area reduces throughout the valve opening leaving less area for the approach flow to push against.

The value of the variables from Equation 6, for the resultant hydraulic force, is listed in Table 9 and Table 10. The line of action quantities (slope and z-intercept described in Section 2.2) for this resulting hydraulic force (Equations 13-16) for the existing valve are listed in Table 11. Illustrations of these lines of action are shown for each valve position in Figure 28 for the $51 \mathrm{ft}$ lift and Figure 29 for the $59 \mathrm{ft}$ lift. Positive slope values correspond to positive vertical hydraulic forces. These plots show how the vertical hydraulic force changes from downpull (negative) to uplift (positive) during the valve opening sequence for both lifts. Note that, although the line of action intersects the valve skin plate, the location where the resultant hydraulic force acts on the valve (the center of pressure) cannot be precisely determined with the information from the physical model.

Table 9. Existing valve hydraulic loads $-51 \mathrm{ft}$ lift.

\begin{tabular}{|c|c|c|c|c|c|c|c|c|c|c|}
\hline \multirow{2}{*}{$\begin{array}{c}\text { Valve } \\
\begin{array}{c}\text { Position } \\
\text { b/B }\end{array}\end{array}$} & $\begin{array}{c}\text { Valve } \\
\text { Position } \\
\text { (ft) }\end{array}$ & \multicolumn{3}{|c|}{$\begin{array}{c}\text { Vertical Hydraulic Load } \\
\text { (kips) }\end{array}$} & \multicolumn{3}{|c|}{$\begin{array}{c}\text { Longitudinal Hydraulic } \\
\text { Load (kips) }\end{array}$} & \multicolumn{3}{|c|}{$\begin{array}{c}\text { Resultant Hydraulic } \\
\text { Load (kips) }\end{array}$} \\
\hline 0.15 & 2.25 & -68.4 & -53.5 & -82.1 & 144.4 & 167.0 & 131.9 & 159.8 & 183.3 & 145.6 \\
\hline 0.20 & 3.00 & -45.8 & -29.9 & -58.8 & 107.0 & 118.1 & 95.1 & 116.5 & 130.8 & 101.9 \\
\hline 0.25 & 3.75 & -36.1 & -17.7 & -53.8 & 109.2 & 125.4 & 94.7 & 115.1 & 135.9 & 97.0 \\
\hline 0.30 & 4.50 & -22.5 & -5.3 & -38.3 & 114.3 & 135.6 & 94.4 & 116.6 & 137.7 & 95.6 \\
\hline 0.35 & 5.25 & -15.2 & 0.4 & -28.4 & 114.5 & 135.7 & 90.7 & 115.6 & 137.8 & 90.7 \\
\hline 0.40 & 6.00 & -5.8 & 8.5 & -20.9 & 94.8 & 118.3 & 65.0 & 95.0 & 119.3 & 65.0 \\
\hline 0.50 & 7.50 & 10.5 & 28.1 & -7.8 & 74.6 & 101.6 & 46.9 & 75.6 & 101.6 & 49.5 \\
\hline 0.60 & 9.00 & 23.1 & 47.3 & 3.0 & 52.7 & 85.5 & 20.6 & 58.1 & 86.6 & 33.5 \\
\hline 0.80 & 12.00 & 37.8 & 55.2 & 19.5 & 10.5 & 23.5 & -5.9 & 39.5 & 56.4 & 24.7 \\
\hline
\end{tabular}


Table 10. Existing valve hydraulic loads $-59 \mathrm{ft}$ lift.

\begin{tabular}{|c|c|c|c|c|c|c|c|c|c|c|}
\hline \multirow{2}{*}{$\begin{array}{c}\text { Valve } \\
\text { Position }\end{array}$} & \multirow{2}{*}{$\begin{array}{c}\text { Valve } \\
\text { Position } \\
\text { (ft) }\end{array}$} & \multicolumn{3}{|c|}{$\begin{array}{c}\text { Vertical Hydraulic Load } \\
\text { (kips) }\end{array}$} & \multicolumn{3}{|c|}{$\begin{array}{c}\text { Longitudinal Hydraulic } \\
\text { Load (kips) }\end{array}$} & \multicolumn{3}{|c|}{$\begin{array}{c}\text { Resultant Hydraulic } \\
\text { Load (kips) }\end{array}$} \\
\hline & Mean & Max & Min & Mean & Max & Min & Mean & Max & Min \\
\hline 0.10 & 1.50 & -73.0 & -59.6 & -83.7 & 156.7 & 171.1 & 138.7 & 172.9 & 190.2 & 152.5 \\
\hline 0.15 & 2.25 & -67.8 & -48.7 & -85.0 & 158.3 & 172.5 & 144.1 & 172.3 & 188.3 & 154.8 \\
\hline 0.20 & 3.00 & -64.4 & -47.3 & -78.2 & 144.2 & 164.2 & 120.7 & 158.1 & 179.3 & 133.3 \\
\hline 0.25 & 3.75 & - & - & - & - & - & - & - & - & - \\
\hline 0.30 & 4.50 & - & - & - & - & - & - & - & - & - \\
\hline 0.35 & 5.25 & -37.6 & -18.2 & -60.0 & 137.7 & 157.4 & 122.4 & 143.0 & 162.5 & 124.5 \\
\hline 0.40 & 6.00 & -20.8 & -2.7 & -37.4 & 127.9 & 151.3 & 104.2 & 129.6 & 154.5 & 104.5 \\
\hline 0.50 & 7.50 & 0.5 & 22.1 & -16.4 & 91.2 & 132.1 & 58.7 & 91.3 & 132.6 & 59.5 \\
\hline 0.60 & 9.00 & 9.7 & 43.8 & -14.6 & 60.3 & 115.0 & 20.3 & 62.0 & 115.1 & 24.8 \\
\hline
\end{tabular}

Table 11. Existing valve hydraulic force line of action values, both lifts.

\begin{tabular}{|c|c|c|c|c|c|c|}
\hline \multirow[b]{2}{*}{ 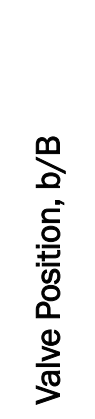 } & \multicolumn{3}{|c|}{$51 \mathrm{ft} \mathrm{Lift}$} & \multicolumn{3}{|c|}{$59 \mathrm{ft}$ Lift } \\
\hline & 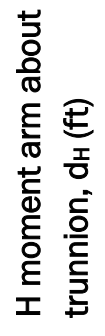 & 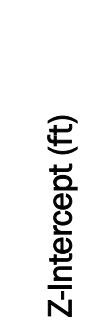 & $\begin{array}{l}\varepsilon \\
\Phi \\
\frac{0}{\omega}\end{array}$ & 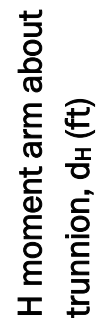 & 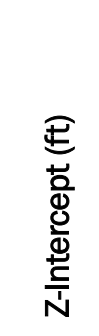 & $\begin{array}{l}\varepsilon \\
\Phi \\
\frac{0}{0}\end{array}$ \\
\hline 0.15 & 1.98 & -2.19 & -0.47 & 2.1 & -2.3 & -0.47 \\
\hline 0.20 & 2.62 & -2.85 & -0.43 & 2.5 & -2.7 & -0.43 \\
\hline 0.25 & 3.61 & -3.79 & -0.33 & 2.1 & -2.3 & -0.45 \\
\hline 0.30 & 4.6 & -4.69 & -0.20 & - & - & - \\
\hline 0.35 & 5.33 & -5.37 & -0.13 & - & - & - \\
\hline 0.40 & 6.19 & -6.2 & -0.06 & 3.4 & -3.5 & -0.27 \\
\hline 0.50 & 8.31 & -8.39 & 0.15 & 4.6 & -4.6 & -0.16 \\
\hline 0.60 & 11.3 & -12.4 & 0.45 & 7.7 & -7.7 & 0.01 \\
\hline 0.80 & 15.5 & -59 & 3.48 & 11.4 & -11.7 & 0.25 \\
\hline
\end{tabular}


Figure 28. Existing valve resultant hydraulic force line of action $-51 \mathrm{ft} \mathrm{lift.}$

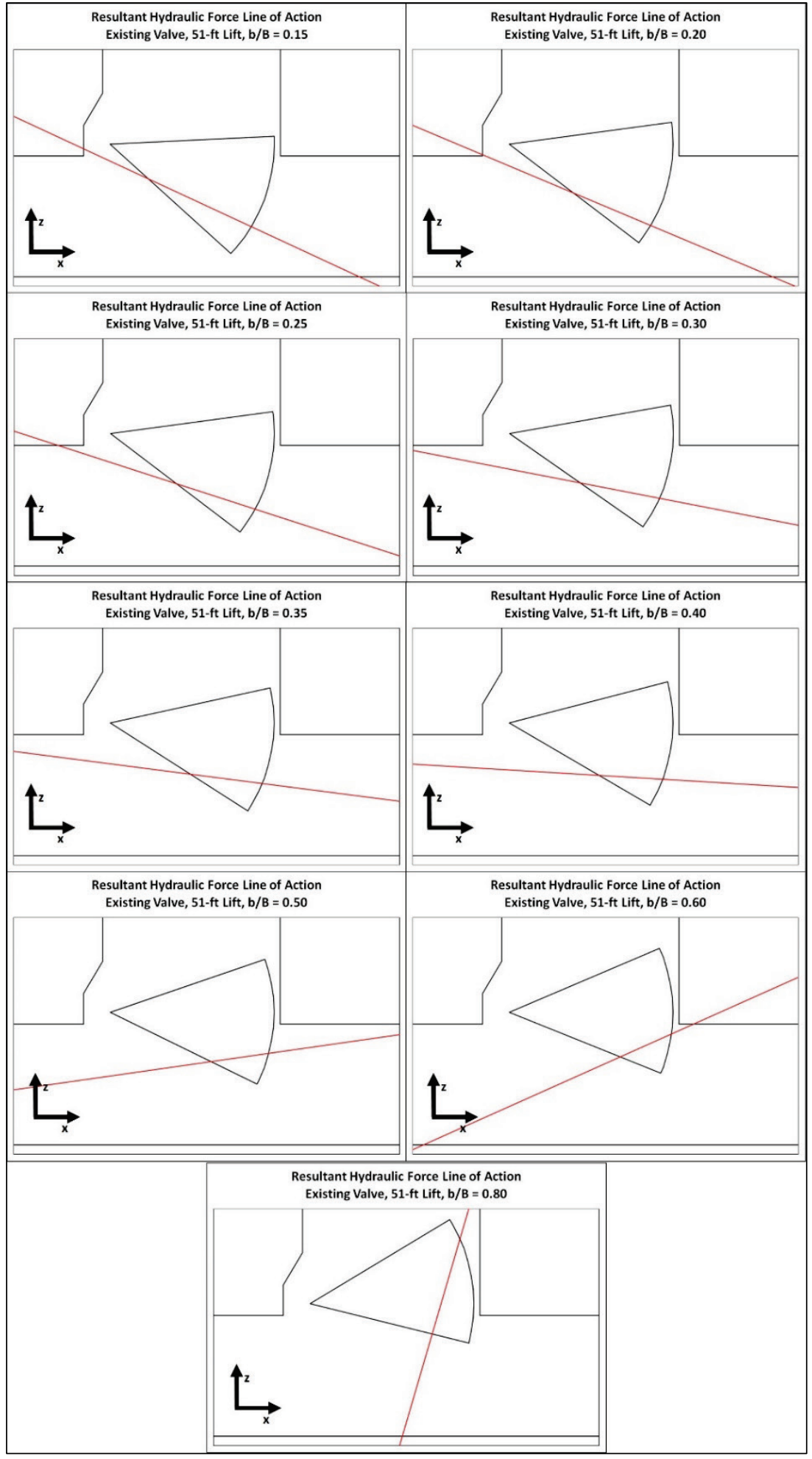


Figure 29. Existing valve resultant hydraulic force line of action $-59 \mathrm{ft}$ lift.

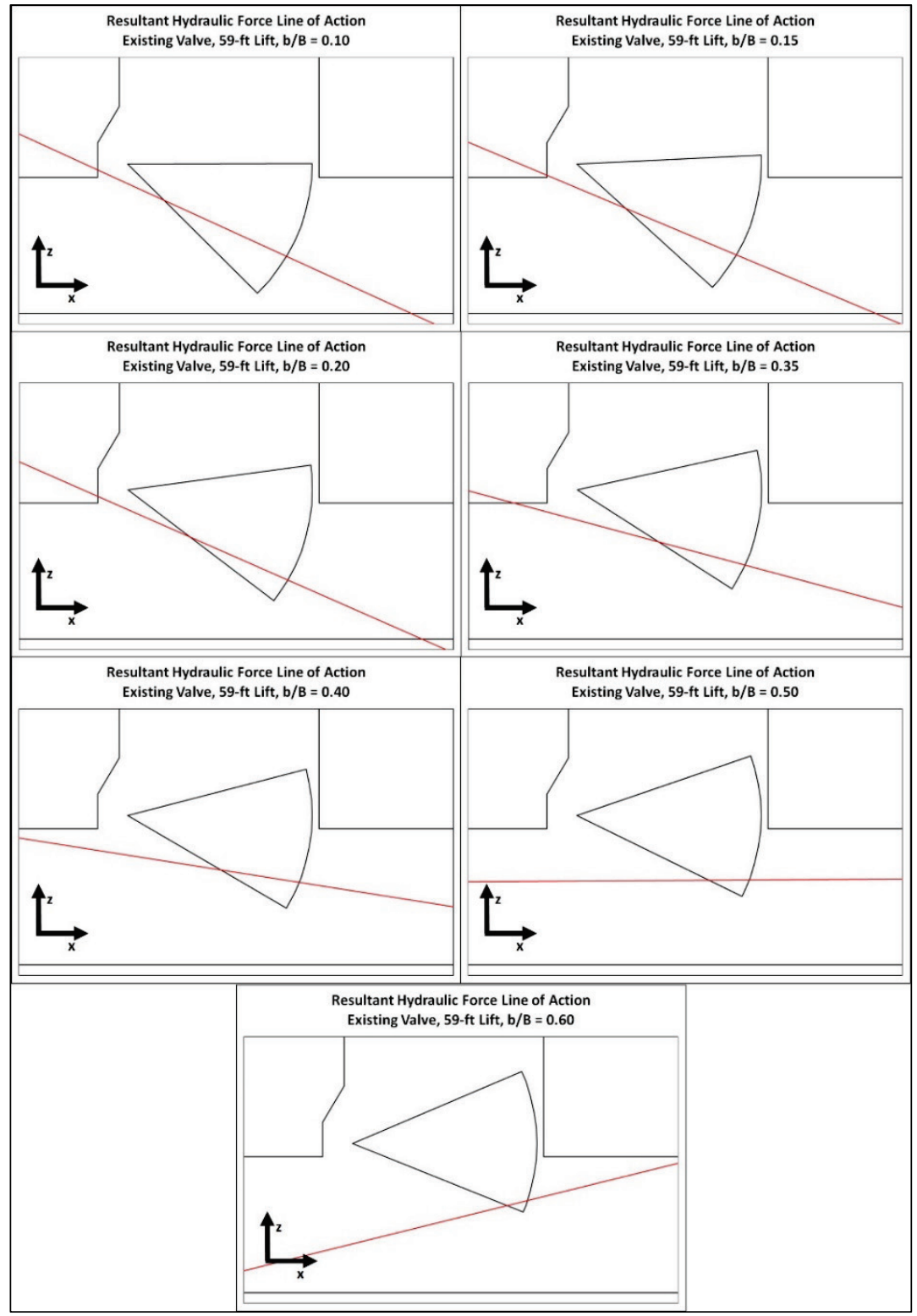

\subsubsection{Pressure}

The pressures for each piezometer along the culvert during the existing valve experiments are shown in Table 12 and Table 13. Plots of these values in the scaled culvert section of the facility are included in Appendix A. The pressure head begins near the upper pool elevation but drops dramatically across the valve (from Piezometer 4 to Piezometer 5). Downstream of Piezometer 5, the pressure head recovers and is much more pronounced at valve positions above $\mathrm{b} / \mathrm{B}=0.20$. For the $51 \mathrm{ft}$ lift, the pressure head minimum mean value is $342.8 \mathrm{ft}$ and for a $59 \mathrm{ft}$ lift, the pressure head minimum value is $330.0 \mathrm{ft}-$ both at $\mathrm{b} / \mathrm{B}=0.35$. 
Table 12. Existing valve pressure head in feet of prototype elevation- $51 \mathrm{ft} \mathrm{lift.}$

\begin{tabular}{|c|c|c|c|c|c|c|c|c|c|c|c|}
\hline \multicolumn{2}{|c|}{$\begin{array}{c}\text { Valve Position } \\
\text { b/B }\end{array}$} & \multirow{2}{*}{$\frac{0.10}{-}$} & \multirow{2}{*}{$\begin{array}{c}0.15 \\
409.2\end{array}$} & \multirow{2}{*}{$\begin{array}{c}0.20 \\
408.6\end{array}$} & \multirow{2}{*}{$\begin{array}{c}0.25 \\
408.3\end{array}$} & \multirow{2}{*}{$\begin{array}{c}0.30 \\
407.6\end{array}$} & \multirow{2}{*}{$\begin{array}{c}0.35 \\
406.9\end{array}$} & \multirow{2}{*}{$\begin{array}{c}0.40 \\
405.9\end{array}$} & \multirow{2}{*}{$\frac{0.50}{403.8}$} & \multirow{2}{*}{$\begin{array}{c}0.60 \\
401.8\end{array}$} & \multirow{2}{*}{$\begin{array}{c}0.80 \\
398.6\end{array}$} \\
\hline \multirow{3}{*}{ Piez. 1} & Mean & & & & & & & & & & \\
\hline & Max. & - & 409.5 & 408.7 & 408.3 & 407.6 & 406.9 & 405.9 & 403.8 & 401.8 & 398.6 \\
\hline & Min. & - & 409.0 & 408.3 & 408.3 & 407.6 & 406.9 & 405.9 & 403.8 & 401.8 & 398.6 \\
\hline \multirow{3}{*}{ Piez. 2} & חקم & 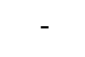 & 409.2 & 408.6 & 407.6 & 407.6 & 406.8 & 405.8 & 403.7 & 401.7 & 398.5 \\
\hline & Max. & - & 409.5 & 408.7 & 408.3 & 407.6 & 406.9 & 405.8 & 403.7 & 401.7 & 398.5 \\
\hline & Min. & - & 409.0 & 408.3 & 406.2 & 407.5 & 406.8 & 405.8 & 403.7 & 401.7 & 398.5 \\
\hline \multirow{3}{*}{ Piez. 3} & (n) & 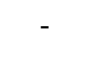 & 409.0 & 408.3 & 408.0 & 407.2 & 406.4 & 405.3 & 403.0 & 401.1 & 398.1 \\
\hline & Max. & - & 409.1 & 408.5 & 408.1 & 407.3 & 406.5 & 405.5 & 403.1 & 401.3 & 398.2 \\
\hline & $\mathrm{N}$ & - & 408.9 & 408.0 & 408.0 & 407.2 & 406.2 & 405.0 & 403.0 & 401.0 & 398.0 \\
\hline \multirow{3}{*}{ Piez. 4} & Mean & - & 342.8 & 354.3 & 353.9 & 354.5 & 354.6 & 360.3 & 369.0 & 374.7 & 388.4 \\
\hline & Max. & - & 343.0 & 355.4 & 354.8 & 356.1 & 355.5 & 360.5 & 369.1 & 375.3 & 389.0 \\
\hline & Min. & - & 342.6 & 352.5 & 353.3 & 352.8 & 354.0 & 360.0 & 368.8 & 374.3 & 388.0 \\
\hline \multirow{3}{*}{ Piez. 5} & Mean & - & 343.0 & 353.3 & 353.1 & 352.8 & 350.9 & 354.2 & 359.4 & 365.1 & 387.2 \\
\hline & Max. & - & 343.3 & 354.5 & 354.1 & 354.5 & 351.8 & 354.5 & 359.5 & 365.5 & 388.0 \\
\hline & Min. & - & 342.8 & 352.0 & 352.3 & 351.0 & 350.0 & 354.0 & 359.3 & 364.7 & 386.3 \\
\hline \multirow{3}{*}{ Piez. 6} & Mean & - & 344.3 & 353.5 & 353.4 & 352.8 & 350.8 & 354.2 & 360.5 & 371.2 & 389.5 \\
\hline & Max. & - & 344.8 & 355.0 & 354.0 & 354.5 & 351.9 & 354.2 & 360.6 & 378.0 & 391.2 \\
\hline & Min. & - & 344.0 & 352.2 & 352.8 & 350.8 & 350.2 & 354.2 & 360.4 & 367.1 & 388.3 \\
\hline \multirow{3}{*}{ Piez. 7} & Mean & - & 350.5 & 361.1 & 360.1 & 356.2 & 357.6 & 362.1 & 371.8 & 378.9 & 393.3 \\
\hline & Max. & - & 351.0 & 362.0 & 360.8 & 359.5 & 358.5 & 362.8 & 372.5 & 379.8 & 394.1 \\
\hline & Min. & - & 350.0 & 359.8 & 359.3 & 351.0 & 356.0 & 361.5 & 371.0 & 377.7 & 392.5 \\
\hline \multirow{3}{*}{ Piez. 8} & Mean & - & 352.6 & 364.4 & 365.3 & 362.6 & 367.5 & 371.8 & 378.4 & 383.4 & 393.9 \\
\hline & Max. & - & 352.8 & 365.3 & 366.0 & 365.9 & 368.0 & 372.0 & 378.5 & 383.7 & 394.6 \\
\hline & Min. & - & 352.5 & 362.9 & 364.9 & 359.5 & 367.2 & 371.5 & 378.2 & 382.9 & 393.0 \\
\hline \multirow{3}{*}{ Piez. 9} & Mean & - & 409.5 & 408.8 & 408.8 & 407.9 & 406.8 & 405.5 & 403.4 & 400.5 & 396.7 \\
\hline & Max. & - & 410.0 & 409.0 & 408.9 & 407.9 & 406.9 & 405.7 & 403.6 & 400.7 & 397.6 \\
\hline & Min. & - & 409.0 & 408.4 & 408.8 & 407.8 & 406.7 & 405.3 & 403.2 & 400.3 & 396.0 \\
\hline
\end{tabular}


Table 13. Existing valve pressure head in feet of prototype elevation $-59 \mathrm{ft}$ lift.

\begin{tabular}{|c|c|c|c|c|c|c|c|c|c|c|c|}
\hline \multicolumn{2}{|c|}{$\begin{array}{c}\text { Valve Position } \\
\text { b/B }\end{array}$} & \multirow{2}{*}{$\begin{array}{c}0.10 \\
413.1\end{array}$} & \multirow{2}{*}{$\begin{array}{c}0.15 \\
412.9\end{array}$} & \multirow{2}{*}{$\begin{array}{c}0.20 \\
411.8\end{array}$} & \multirow{2}{*}{$\frac{0.30}{-}$} & \multirow{2}{*}{$\frac{0.40}{-}$} & \multirow{2}{*}{$\begin{array}{c}0.35 \\
409.0\end{array}$} & \multirow{2}{*}{$\begin{array}{l}0.40 \\
407.7\end{array}$} & \multirow{2}{*}{\begin{tabular}{|c|}
0.50 \\
404.8
\end{tabular}} & \multirow{2}{*}{$\begin{array}{c}0.60 \\
401.6\end{array}$} & \multirow{2}{*}{$\frac{0.80}{-}$} \\
\hline \multirow{3}{*}{ Piez. 1} & Mean & & & & & & & & & & \\
\hline & Max. & 413.5 & 413.3 & 411.8 & - & - & 409.0 & 407.7 & 404.8 & 401.6 & - \\
\hline & Min. & 412.7 & 412.4 & 411.8 & - & - & 409.0 & 407.7 & 404.8 & 401.6 & - \\
\hline \multirow{3}{*}{ Piez. 2} & Mean & 413.1 & 412.9 & 411.8 & - & - & 409.0 & 407.6 & 404.7 & 401.5 & - \\
\hline & Max. & 413.5 & 413.3 & 411.8 & - & - & 409.0 & 407.6 & 404.7 & 401.5 & - \\
\hline & Min. & 412.7 & 412.4 & 411.8 & - & - & 408.9 & 407.6 & 404.7 & 401.5 & - \\
\hline \multirow{3}{*}{ Piez. 3} & Mean & 413.1 & 412.7 & 411.6 & - & - & 408.5 & 406.8 & 403.9 & 400.7 & - \\
\hline & Max. & 413.5 & 413.1 & 411.7 & - & - & 409.1 & 406.9 & 404.1 & 400.7 & - \\
\hline & Min. & 412.8 & 412.2 & 411.6 & - & - & 408.0 & 406.8 & 403.5 & 400.6 & - \\
\hline \multirow{3}{*}{ Piez. 4} & Mean & 346.1 & 342.0 & 341.2 & - & - & 333.7 & 343.3 & 354.0 & 362.6 & - \\
\hline & Max. & 348.7 & 342.4 & 343.5 & - & - & 335.0 & 347.5 & 354.5 & 363.7 & - \\
\hline & Min. & 342.5 & 341.6 & 340.0 & - & - & 333.0 & 341.0 & 353.5 & 361.5 & - \\
\hline \multirow{3}{*}{ Piez. 5} & Mean & 348.0 & 342.4 & 339.8 & - & - & 330.0 & 332.0 & 339.0 & 348.2 & - \\
\hline & Max. & 348.7 & 342.7 & 342.9 & - & - & 330.0 & 333.0 & 340.0 & 349.5 & - \\
\hline & Min. & 347.3 & 342.0 & 338.0 & - & - & 330.0 & 330.0 & 338.0 & 347.5 & - \\
\hline \multirow{3}{*}{ Piez. 6} & Mean & 348.3 & 343.8 & 340.4 & - & - & 330.0 & 333.0 & 340.7 & 351.8 & - \\
\hline & Max. & 351.0 & 344.0 & 343.2 & - & - & 330.0 & 333.0 & 341.0 & 353.0 & - \\
\hline & Min. & 344.5 & 343.5 & 338.9 & - & - & 330.0 & 333.0 & 340.1 & 350.5 & - \\
\hline \multirow{3}{*}{ Piez. 7} & Mean & 352.3 & 350.1 & 350.0 & - & - & 340.7 & 344.7 & 356.5 & 368.7 & - \\
\hline & Max. & 353.8 & 350.4 & 352.5 & - & - & 341.0 & 347.0 & 357.0 & 369.5 & - \\
\hline & Min. & 350.7 & 350.0 & 348.5 & - & - & 340.0 & 341.5 & 356.0 & 367.5 & - \\
\hline \multirow{3}{*}{ Piez. 8} & Mean & 355.3 & 352.7 & 354.2 & - & - & 352.9 & 356.8 & 367.7 & 375.2 & - \\
\hline & Max. & 358.0 & 352.8 & 356.5 & - & - & 353.0 & 358.1 & 368.2 & 376.0 & - \\
\hline & Min. & 353.0 & 352.5 & 352.9 & - & - & 352.8 & 354.4 & 367.5 & 374.5 & - \\
\hline \multirow{3}{*}{ Piez. 9} & Mean & 413.1 & 413.3 & 412.2 & - & - & 408.7 & 407.3 & 403.3 & 398.2 & - \\
\hline & Max. & 413.5 & 413.8 & 412.3 & - & - & 409.0 & 407.4 & 403.5 & 398.3 & - \\
\hline & Min. & 412.9 & 412.4 & 412.0 & - & - & 408.5 & 407.3 & 403.2 & 398.0 & - \\
\hline
\end{tabular}




\subsection{Modified valve}

\subsubsection{Valve description - modified valve}

The modified Pickwick Lock culvert valve is shown in Figure 30 (line drawing) and Figure 31 (photograph). This valve retains the open-framed (vertically framed) design but has a few key differences from the existing Pickwick Lock culvert valve. These differences are illustrated in Figure 32. The plate that extends across the valve at the top of the skin plate is removed. Removing this plate is shown to reduce the hoist load in reverse tainter valves (Bislip and Hite 2013; Stockstill et al. 2015). The horizontal skin plate stiffeners are removed in an effort to reduce vertical vibrations of the valve during the filling and emptying operation. The idea behind this removal is that as the flow travels upward along the skin plate, it likely separates as it passes these horizontal plates, which can cause pressure fluctuations making the valve vibrate. Removing these skin plate stiffeners is thought to further reduce the vertical hydraulic force on the valve, which should reduce the load required to lift the valve (hoist load). To compensate for the loss in skin plate stiffness, two vertical skin plate ribs are added (eleven instead of nine).

Figure 30. Modified Pickwick Lock culvert valve geometry - 4-view.

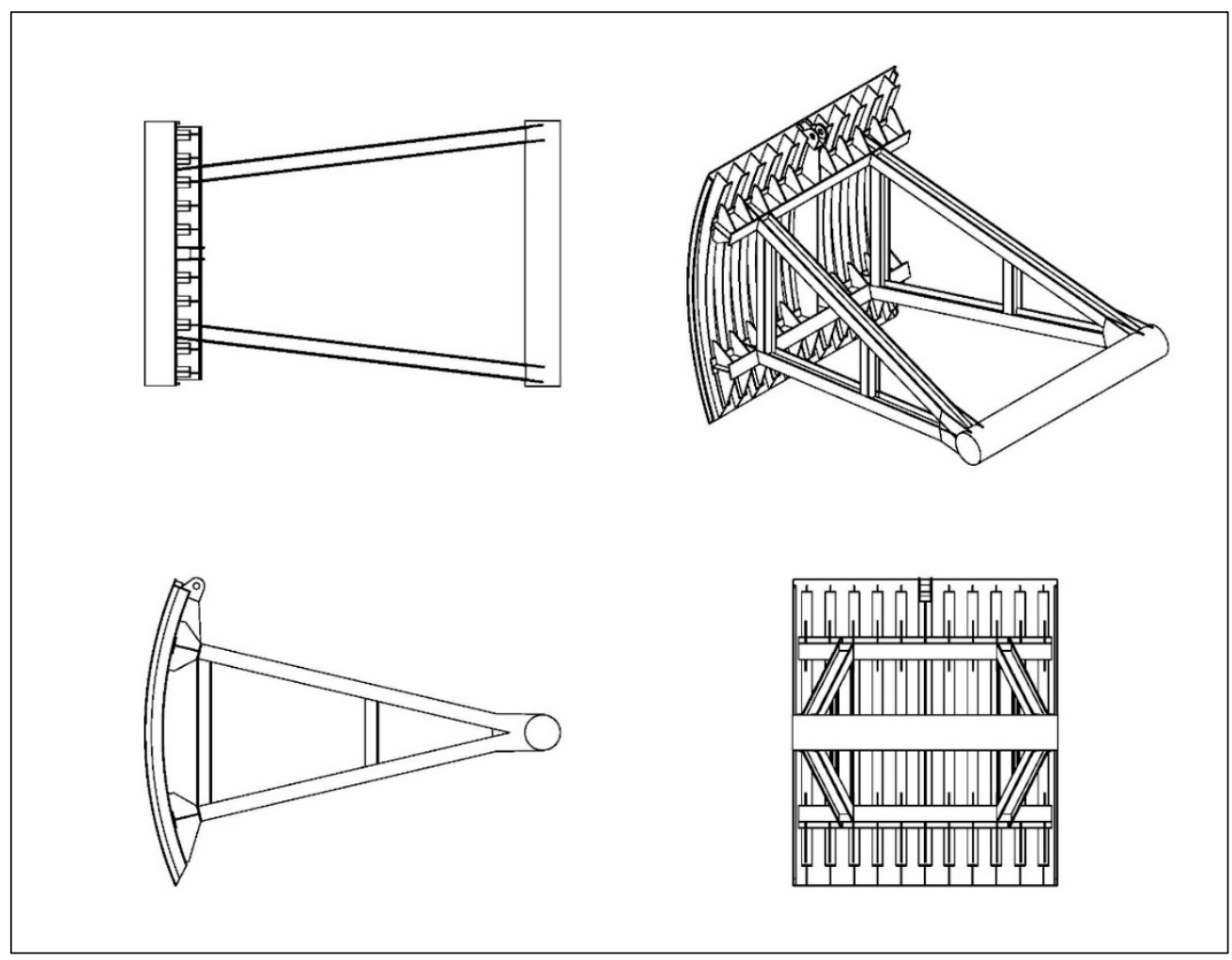


Figure 31. Model valve - modified design.

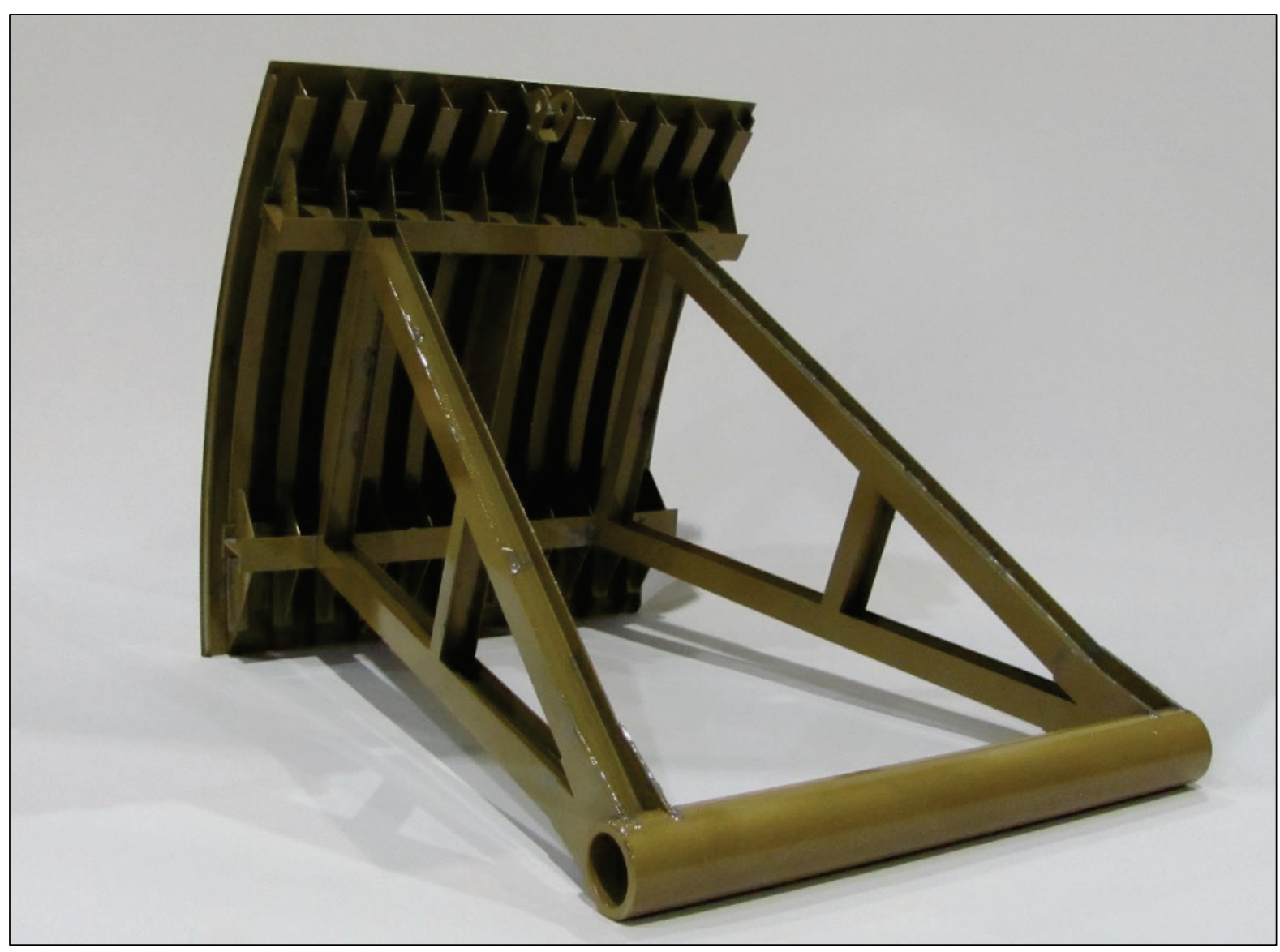


Figure 32. Differences in existing and modified Pickwick Lock culvert valve designs.

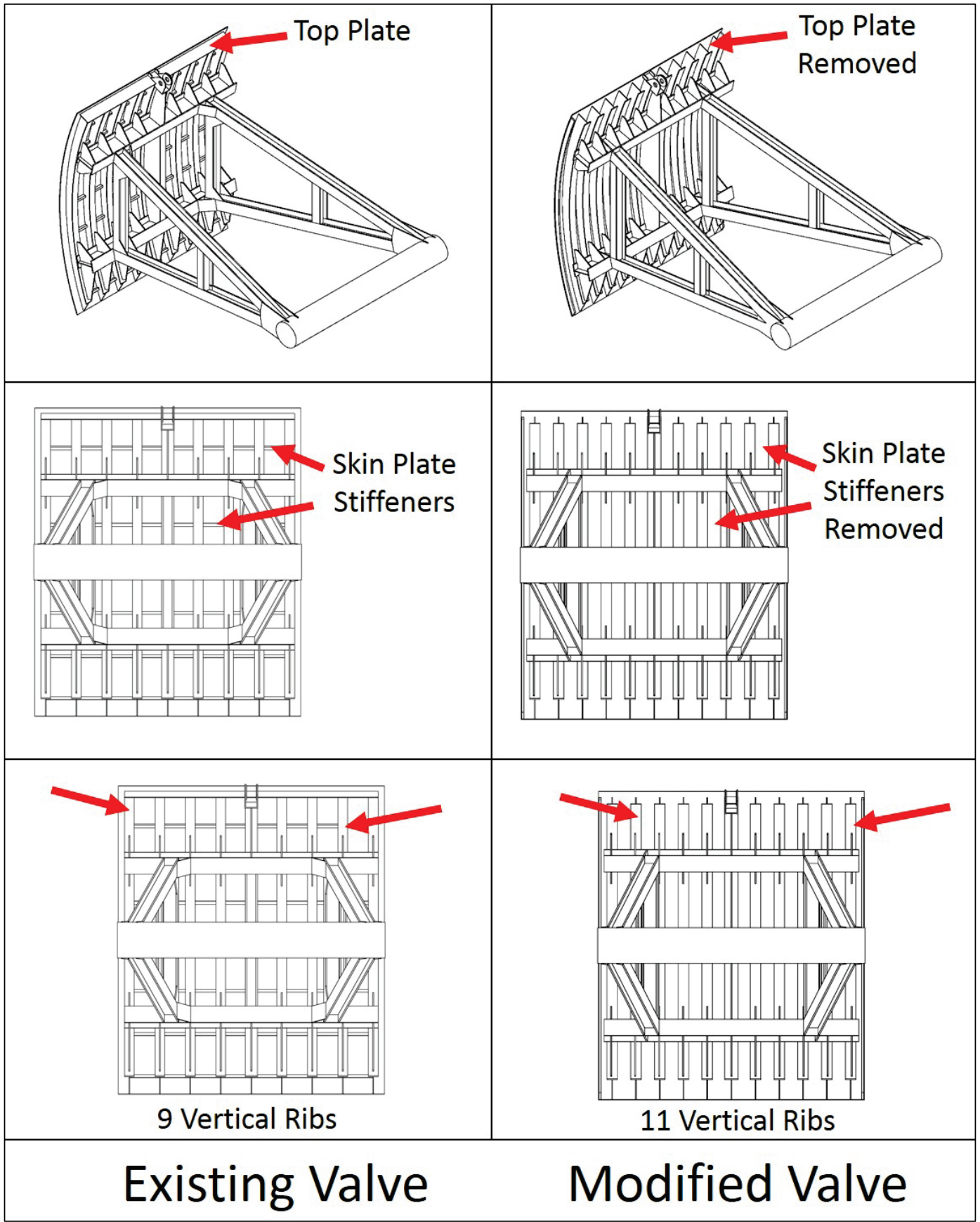

\subsubsection{Flow behavior - modified valve}

The flow near the modified valve is qualitatively similar to flow near reverse tainter gate valves at other navigation locks. The flow is observed with dye releases from multiple vertical positions within the culvert, upstream of the valve. Figure 33 shows the dye around the valve for an experiment at $\mathrm{b} / \mathrm{B}=0.10$. The dye patterns show that the majority of the 
flow accelerates underneath the valve while some flow travels more slowly along the upstream end of the valve skin plate into the valve well. Some of the flow in the valve well is directed through the gap between the downstream side of the skin plate and the downstream wall of the valve well. Large vertical eddies form in the culvert immediately downstream of the valve.

Figure 33. Dye released upstream of the modified valve, $b / B=0.10$.

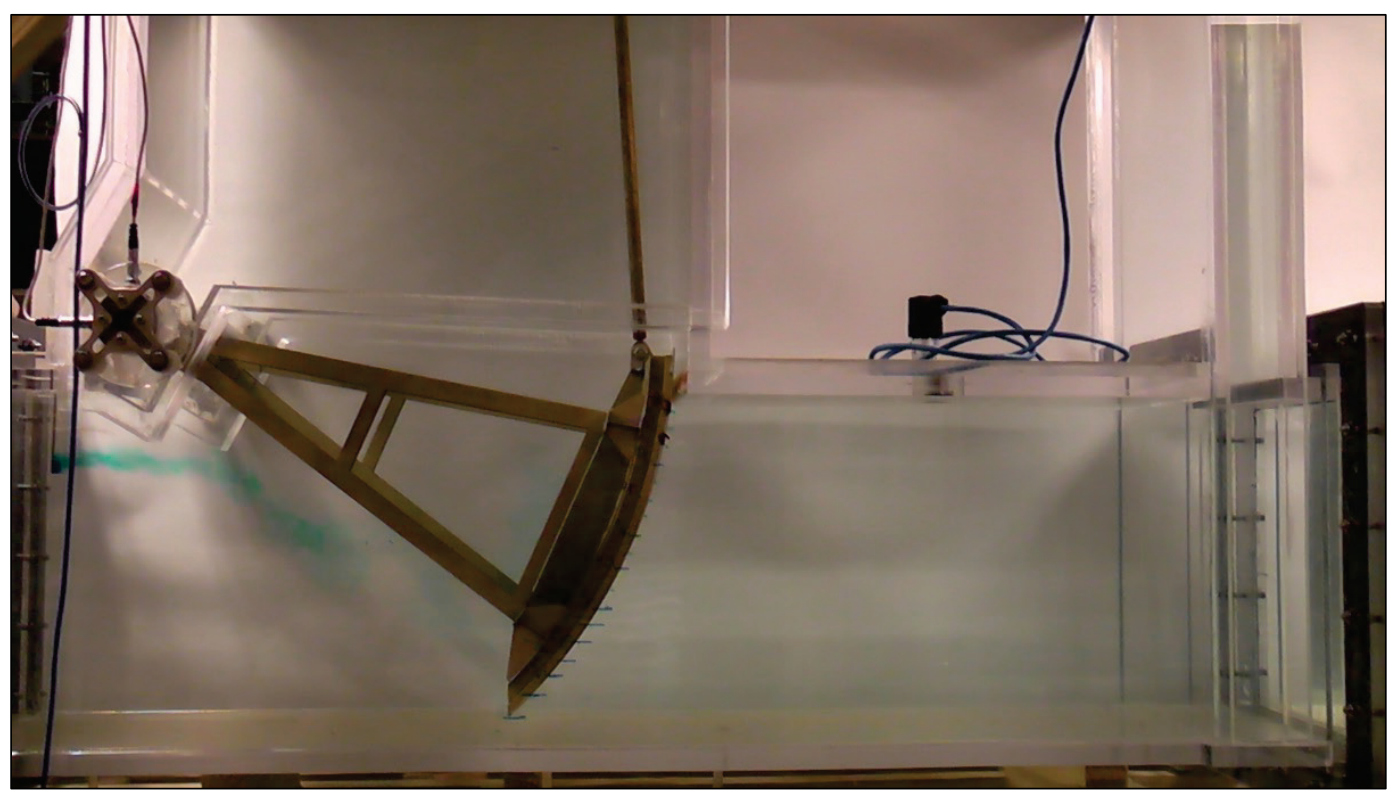

The modified valve produces very similar flow in the downstream bulkhead slot at high valve positions $(\mathrm{b} / \mathrm{B} \geq 0.50)$ as the existing valve. During the experiment, the water surface fluctuates rapidly, and those fluctuations are as much as $15 \mathrm{ft}$ (at prototype scale) throughout experiments where this flow behavior is present. This flow behavior is shown in Figure 34 and Figure 35. The water surface movement indicates very strong pressure fluctuations downstream of the valve that extend past the downstream bulkhead slot. These fluctuations coincide with significant valve vibration. The valve could easily be seen vibrating throughout the higher valve position experiments. At lower valve positions, the downstream bulkhead slot water surface elevation varies much less rapidly and remains fairly level throughout the testing. Also, at the lower valve positions, significant valve vibration does not occur. 
Figure 34. Modified valve at $b / B=0.35-$ downstream bulkhead slot flow.

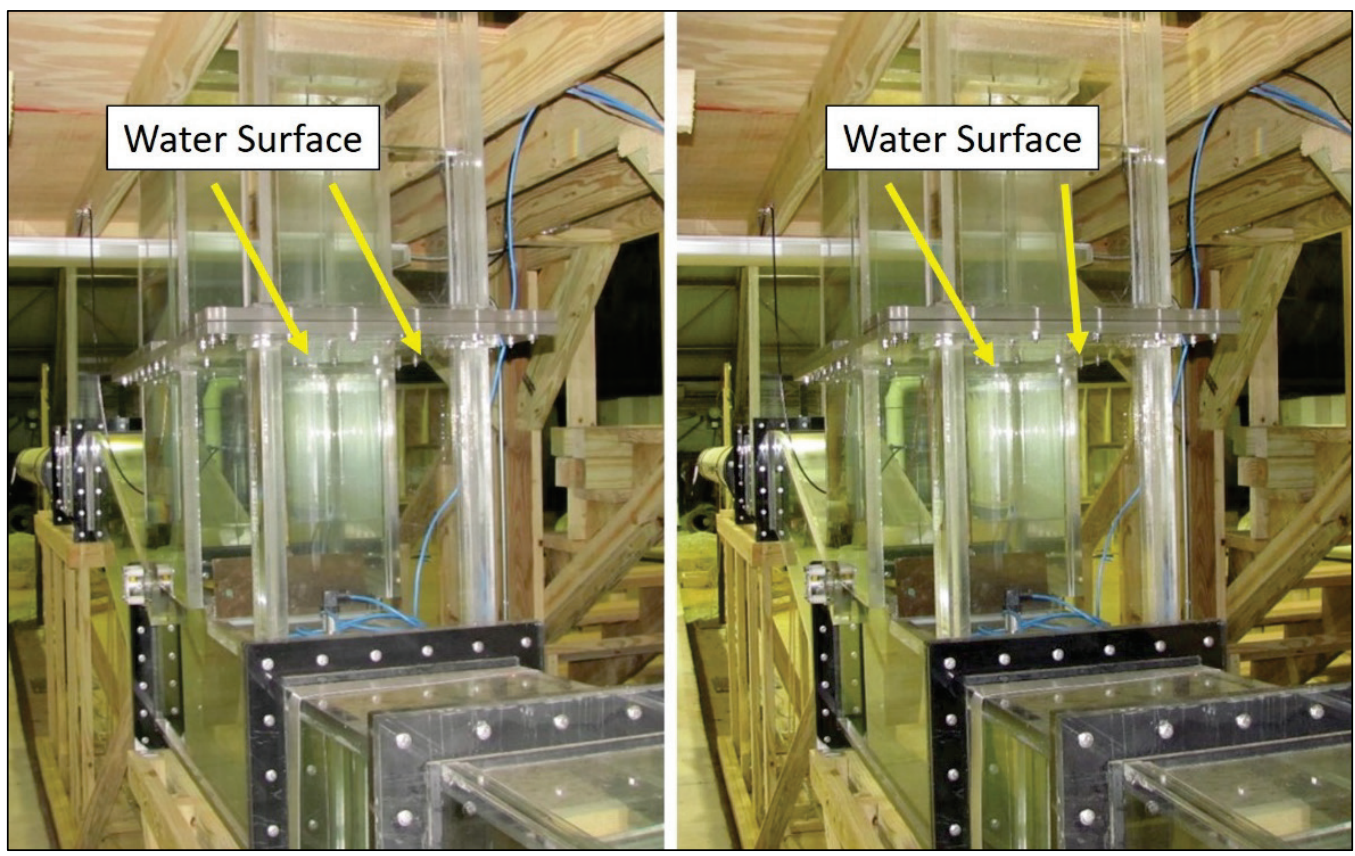

Figure 35 Modified valve at $b / B=0.60-$ downstream bulkhead slot flow.

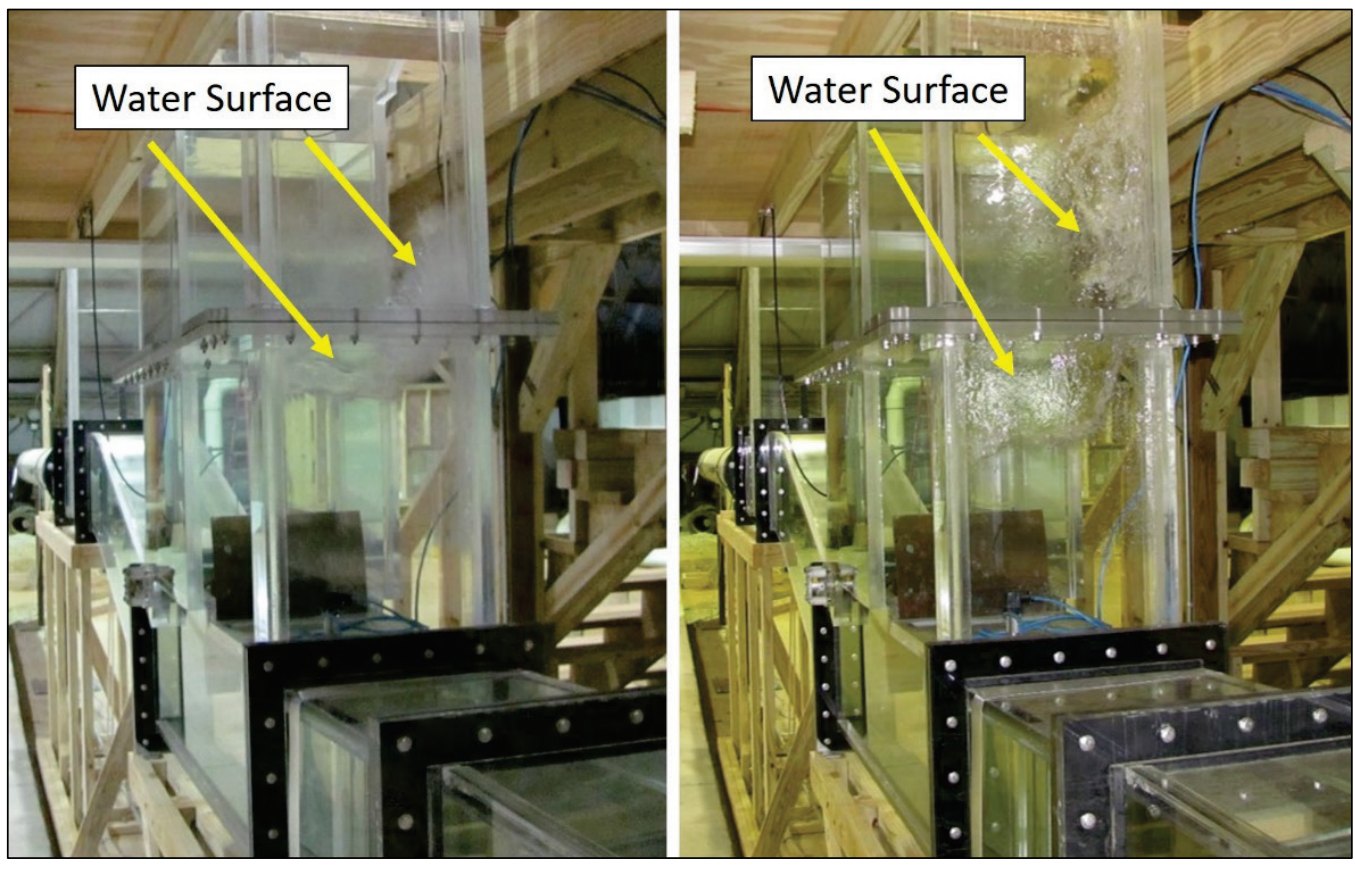

\subsubsection{Load results - modified valve}

The model measurements and the calculated quantities for the modified Pickwick Lock culvert valve are presented for each lift before proceeding to another type of load. This order is intended to highlight the difference in valve performance from changes in the lift and culvert discharge. The 
mean loads are the focus of the results included in this section. The maximum and minimum values, which are used for prototype design calculations, follow essentially the same trend as the mean values. Tables of the mean, maximum, minimum, and mean values are included in this section, and plots of these values listed are included in Appendix B.

\subsubsection{Hoist loads}

The modified valve hoist loads are listed in Table 14. The dry load is removed from the reported values (Equation 19). For the $51 \mathrm{ft}$ lift, the mean hoist load ranges from $1.8 \mathrm{kips}$ in tension (at $\mathrm{b} / \mathrm{B}=0.40$ ) to 6 kips in compression (at the $\mathrm{b} / \mathrm{B}=0.80$ ). For the $59 \mathrm{ft}$ lift, the mean hoist load varies between 0.4 kips of tension (at $\mathrm{b} / \mathrm{B}=0.35$ ) and 5 kips in compression ( $\mathrm{at} \mathrm{b} / \mathrm{B}=0.60$ ). The mean hoist load is fairly consistent throughout the valve opening for both lifts. Plots of the values listed in Table 14 are included in Appendix B.

Table 14. Modified valve hoist loads, 51 and $59 \mathrm{ft}$ lifts.

\begin{tabular}{|c|c|c|c|c|c|c|c|}
\hline \multirow{3}{*}{$\begin{array}{c}\text { Valve } \\
\text { Position } \\
\text { b/B }\end{array}$} & \multirow{3}{*}{$\begin{array}{l}\text { Valve } \\
\text { Position } \\
\text { (ft) }\end{array}$} & \multicolumn{6}{|c|}{ Hoist Load (kips) } \\
\hline & & \multicolumn{3}{|c|}{$51 \mathrm{ft}$ Lift } & \multicolumn{3}{|c|}{$59 \mathrm{ft} \mathrm{Lift}$} \\
\hline & & Mean & Max & Min & Mean & Max & Min \\
\hline 0.10 & 1.50 & - & - & - & -0.3 & 4.1 & -5.5 \\
\hline 0.15 & 2.25 & -0.1 & 4.8 & -6.1 & -3.6 & 1.4 & -7.9 \\
\hline 0.20 & 3.00 & 0.7 & 6.8 & -6.3 & -1.9 & 1.8 & -6.9 \\
\hline 0.25 & 3.75 & 0.3 & 6.2 & -6.4 & - & - & - \\
\hline 0.30 & 4.50 & 1.4 & 6.0 & -2.9 & - & - & - \\
\hline 0.35 & 5.25 & 0.3 & 6.2 & -5.0 & 0.4 & 4.9 & -4.8 \\
\hline 0.40 & 6.00 & 1.8 & 6.1 & -3.2 & 0.3 & 4.7 & -4.9 \\
\hline 0.50 & 7.50 & -1.2 & 5.2 & -8.4 & -1.9 & 4.4 & -8.4 \\
\hline 0.60 & 9.00 & -3.3 & 2.5 & -9.8 & -5.0 & 2.2 & -13.4 \\
\hline 0.80 & 12.00 & -5.5 & -1.0 & -10.4 & - & - & - \\
\hline
\end{tabular}

\subsubsection{Trunnion loads}

The modified valve trunnion loads are listed in Table 15 and Table 16. These values are indicated in Equations 20 through 22. The vertical trunnion load decreases (generally linearly) throughout the valve opening for both lifts. For the $51 \mathrm{ft}$ lift, the mean vertical trunnion load extends from 96.3 kips ( $\mathrm{at} \mathrm{b} / \mathrm{B}=0.15$ ) to $4.4 \mathrm{kips}(\mathrm{at} \mathrm{b} / \mathrm{B}=0.80$ ). The mean 
vertical trunnion load for the $59 \mathrm{ft}$ lift ranges from $125.4 \mathrm{kips}(\mathrm{at} \mathrm{b} / \mathrm{B}=$ 0.10 ) to 29.0 kips ( $a t b / \mathrm{B}=0.60$ ). The longitudinal trunnion loads are much larger than the vertical trunnion loads. The longitudinal trunnion load decreases (generally not linearly) throughout the valve opening. For the $51 \mathrm{ft}$ lift, the longitudinal trunnion load varies between $242 \mathrm{kips}$ (at $\mathrm{b} / \mathrm{B}=0.15$ ) and 22.6 kips (at $\mathrm{b} / \mathrm{B}=0.80$ ), respectively. For the $59 \mathrm{ft}$ lift, the mean longitudinal trunnion loads have a range of $287.1 \mathrm{kips}(\mathrm{at} \mathrm{b} / \mathrm{B}=$ 0.15 ) to $136.6 \mathrm{kips}$ ( $\mathrm{at} \mathrm{b} / \mathrm{B}=0.60$ ). The mean resultant trunnion load for the $51 \mathrm{ft}$ lift extends from 260.5 kips (at $\mathrm{b} / \mathrm{B}=0.15$ ) to $23.1 \mathrm{kips}(\mathrm{at} \mathrm{b} / \mathrm{B}=$ 0.80 ). For the $59 \mathrm{ft}$ lift, the range is $310.8 \mathrm{kips}(\mathrm{at} \mathrm{b} / \mathrm{B}=0.10$ ) to $139.7 \mathrm{kips}$ (at $\mathrm{b} / \mathrm{B}=0.60$ ). Plots of the values shown in Table 15 and Table 16 are included in Appendix B.

Table 15. Modified valve trunnion loads $-51 \mathrm{ft}$ lift.

\begin{tabular}{|c|c|c|c|c|c|c|c|c|c|c|}
\hline \multirow{2}{*}{$\begin{array}{c}\text { Valve } \\
\text { Position }\end{array}$} & \multirow{2}{*}{$\begin{array}{c}\text { Valve } \\
\text { Position } \\
\text { b/Bt) }\end{array}$} & \multicolumn{3}{|c|}{$\begin{array}{c}\text { Vertical Trunnion Load } \\
\text { (kips) }\end{array}$} & \multicolumn{3}{|c|}{$\begin{array}{c}\text { Longitudinal Trunnion } \\
\text { Load (kips) }\end{array}$} & \multicolumn{3}{|c|}{$\begin{array}{c}\text { Resultant Trunnion } \\
\text { Load (kips) }\end{array}$} \\
\cline { 7 - 12 } & Mean & Max & Min & Mean & Max & Min & Mean & Max & Min \\
\hline 0.15 & 2.25 & 96.3 & 111.5 & 79.2 & 242.1 & 271.8 & 213.2 & 260.5 & 292.7 & 227.4 \\
\hline 0.20 & 3.00 & 66.4 & 80.8 & 48.5 & 186.3 & 208.8 & 160.4 & 197.8 & 222.3 & 168.0 \\
\hline 0.25 & 3.75 & 66.2 & 77.8 & 54.3 & 195.2 & 214.5 & 174.9 & 206.1 & 228.2 & 183.2 \\
\hline 0.30 & 4.50 & 60.5 & 69.3 & 50.2 & 194.0 & 208.6 & 173.5 & 203.3 & 219.8 & 180.6 \\
\hline 0.35 & 5.25 & 54.1 & 65.1 & 41.6 & 182.2 & 198.3 & 164.6 & 190.1 & 208.7 & 170.1 \\
\hline 0.40 & 6.00 & 46.5 & 56.4 & 34.5 & 173.5 & 192.3 & 151.3 & 179.6 & 200.0 & 155.5 \\
\hline 0.50 & 7.50 & 29.7 & 45.2 & 15.9 & 124.5 & 161.2 & 95.3 & 128.0 & 167.4 & 97.1 \\
\hline 0.60 & 9.00 & 19.4 & 32.4 & 7.5 & 90.1 & 128.6 & 51.0 & 92.2 & 131.7 & 52.3 \\
\hline 0.80 & 12.00 & 4.4 & 11.5 & -4.6 & 22.6 & 42.7 & 4.6 & 23.1 & 43.9 & 4.6 \\
\hline
\end{tabular}


Table 16. Modified valve trunnion loads $-59 \mathrm{ft}$ lift.

\begin{tabular}{|c|c|c|c|c|c|c|c|c|c|c|}
\hline \multirow{2}{*}{$\begin{array}{c}\text { Valve } \\
\text { Position } \\
\text { b/B }\end{array}$} & $\begin{array}{c}\text { Valve } \\
\text { Position } \\
\text { (ft) }\end{array}$ & \multicolumn{3}{|c|}{$\begin{array}{c}\text { Vertical Trunnion Load } \\
\text { (kips) }\end{array}$} & \multicolumn{3}{|c|}{$\begin{array}{c}\text { Longitudinal Trunnion } \\
\text { Load (kips) }\end{array}$} & \multicolumn{3}{|c|}{$\begin{array}{c}\text { Resultant Trunnion } \\
\text { Load (kips) }\end{array}$} \\
\cline { 6 - 13 } & Max & Min & Mean & Max & Min & Mean & Max & Min \\
\hline 0.10 & 1.50 & 125.4 & 136.1 & 115.5 & 284.4 & 299.5 & 273.1 & 310.8 & 327.8 & 297.7 \\
\hline 0.15 & 2.25 & 116.2 & 124.6 & 107.1 & 287.1 & 301.1 & 276.2 & 309.8 & 324.8 & 296.2 \\
\hline 0.20 & 3.00 & 96.2 & 105.7 & 86.6 & 261.4 & 277.7 & 242.5 & 278.6 & 296.1 & 258.0 \\
\hline 0.25 & 3.75 & - & - & - & - & - & - & - & - & - \\
\hline 0.30 & 4.50 & - & - & - & - & - & - & - & - & - \\
\hline 0.35 & 5.25 & 78.8 & 88.5 & 69.5 & 266.2 & 283.3 & 249.6 & 277.6 & 296.8 & 259.5 \\
\hline 0.40 & 6.00 & 71.3 & 81.4 & 62.3 & 253.5 & 271.5 & 236.3 & 263.4 & 283.0 & 244.4 \\
\hline 0.50 & 7.50 & 43.1 & 54.0 & 32.0 & 181.8 & 218.4 & 148.0 & 186.8 & 224.3 & 151.4 \\
\hline 0.60 & 9.00 & 29.0 & 42.7 & 13.4 & 136.6 & 184.3 & 86.1 & 139.7 & 188.6 & 87.7 \\
\hline
\end{tabular}

\subsubsection{Trunnion end loads}

The load that each trunnion end is half of the total trunnion load values shown in the previous section. These values for the modified valve are listed in Table 17 and Table 18. For the $51 \mathrm{ft}$ lift, the mean vertical trunnion end load extends from 48.1 kips (at $\mathrm{b} / \mathrm{B}=0.15$ ) to $2.2 \mathrm{kips}$ (at $\mathrm{b} / \mathrm{B}=0.80$ ). The mean vertical trunnion end load for the $59 \mathrm{ft}$ lift ranges from $62.7 \mathrm{kips}(\mathrm{at} \mathrm{b} / \mathrm{B}=0.10$ ) to $14.5 \mathrm{kips}(\mathrm{at} \mathrm{b} / \mathrm{B}=0.60)$. The longitudinal trunnion end loads are much larger than the vertical trunnion end loads. The longitudinal trunnion end load decreases (generally not linearly) during the valve opening. For the $51 \mathrm{ft}$ lift, the longitudinal trunnion end load varies between $121 \mathrm{kips}(\mathrm{at} \mathrm{b} / \mathrm{B}=0.15$ ) and 11.3 kips ( $a t b / B=0.80$ ), respectively. For the $59 \mathrm{ft}$ lift, the mean longitudinal trunnion end loads have a range of $143.6 \mathrm{kips}(\mathrm{at} \mathrm{b} / \mathrm{B}=0.15)$ to $68.3 \mathrm{kips}(\mathrm{at} \mathrm{b} / \mathrm{B}=0.60$ ). The resultant trunnion end loads are the vector sum of the vertical and longitudinal trunnion end loads. The mean resultant trunnion end load for the $51 \mathrm{ft}$ lift extends from $130.3 \mathrm{kips}$ (at $\mathrm{b} / \mathrm{B}=0.15$ ) to 11.5 kips (at $\mathrm{b} / \mathrm{B}=0.80$ ). For the $59 \mathrm{ft}$ lift, the range is 155.4 kips (at $\mathrm{b} / \mathrm{B}=0.10$ ) to $69.8 \mathrm{kips}(\mathrm{at} \mathrm{b} / \mathrm{B}=0.60$ ). Plots of the experimental results are included in Appendix B. 
Table 17. Modified valve trunnion end loads $-51 \mathrm{ft} \mathrm{Lift.}$

\begin{tabular}{|c|c|c|c|c|c|c|c|c|c|c|}
\hline \multirow{2}{*}{$\begin{array}{c}\text { Valve } \\
\text { Position }\end{array}$} & \multirow{2}{*}{$\begin{array}{c}\text { Valve } \\
\text { Position } \\
\text { (ft) }\end{array}$} & \multicolumn{3}{|c|}{$\begin{array}{c}\text { Vertical Trunnion End } \\
\text { Load (kips) }\end{array}$} & \multicolumn{2}{|c|}{$\begin{array}{c}\text { Longitudinal Trunnion } \\
\text { End Load (kips) }\end{array}$} & \multicolumn{3}{|c|}{$\begin{array}{c}\text { Resultant Trunnion End } \\
\text { Load (kips) }\end{array}$} \\
\cline { 7 - 13 } & Mean & Max & Min & Mean & Max & Min & Mean & Max & Min \\
\hline 0.15 & 2.25 & 48.1 & 55.7 & 39.6 & 121.0 & 135.9 & 106.6 & 130.3 & 146.3 & 113.7 \\
\hline 0.20 & 3.00 & 33.2 & 40.4 & 24.3 & 93.1 & 104.4 & 80.2 & 98.9 & 111.2 & 84.0 \\
\hline 0.25 & 3.75 & 33.1 & 38.9 & 27.2 & 97.6 & 107.3 & 87.5 & 103.0 & 114.1 & 91.6 \\
\hline 0.30 & 4.50 & 30.3 & 34.6 & 25.1 & 97.0 & 104.3 & 86.7 & 101.6 & 109.9 & 90.3 \\
\hline 0.35 & 5.25 & 27.0 & 32.5 & 20.8 & 91.1 & 99.1 & 82.3 & 95.0 & 104.3 & 85.1 \\
\hline 0.40 & 6.00 & 23.3 & 28.2 & 17.2 & 86.7 & 96.2 & 75.7 & 89.8 & 100.0 & 77.8 \\
\hline 0.50 & 7.50 & 14.9 & 22.6 & 7.9 & 62.2 & 80.6 & 47.6 & 64.0 & 83.7 & 48.6 \\
\hline 0.60 & 9.00 & 9.7 & 16.2 & 3.8 & 45.0 & 64.3 & 25.5 & 46.1 & 65.8 & 26.2 \\
\hline 0.80 & 12.00 & 2.2 & 5.7 & -2.3 & 11.3 & 21.4 & 2.3 & 11.5 & 21.9 & 2.3 \\
\hline
\end{tabular}

Table 18. Modified valve trunnion end loads $-59 \mathrm{ft}$ Lift.

\begin{tabular}{|c|c|c|c|c|c|c|c|c|c|c|}
\hline \multirow{2}{*}{$\begin{array}{c}\text { Valve } \\
\text { Position }\end{array}$} & \multirow{2}{*}{$\begin{array}{c}\text { Valve } \\
\text { Position } \\
\text { b/ft) }\end{array}$} & \multicolumn{3}{|c|}{$\begin{array}{c}\text { Vertical Trunnion End } \\
\text { Load (kips) }\end{array}$} & \multicolumn{2}{c|}{$\begin{array}{c}\text { Longitudinal Trunnion } \\
\text { End Load (kips) }\end{array}$} & \multicolumn{3}{|c|}{$\begin{array}{c}\text { Resultant Trunnion End } \\
\text { Load (kips) }\end{array}$} \\
\hline 0.10 & 1.50 & 62.7 & 68.0 & 57.8 & 142.2 & 149.8 & 136.6 & 155.4 & 163.9 & 148.9 \\
\hline 0.15 & 2.25 & 58.1 & 62.3 & 53.5 & 143.6 & 150.6 & 138.1 & 154.9 & 162.4 & 148.1 \\
\hline 0.20 & 3.00 & 48.1 & 52.8 & 43.3 & 130.7 & 138.8 & 121.3 & 139.3 & 148.0 & 129.0 \\
\hline 0.25 & 3.75 & - & - & - & - & - & - & - & - & - \\
\hline 0.30 & 4.50 & - & - & - & - & - & - & - & - & - \\
\hline 0.35 & 5.25 & 39.4 & 44.3 & 34.7 & 133.1 & 141.6 & 124.8 & 138.8 & 148.4 & 129.7 \\
\hline 0.40 & 6.00 & 35.7 & 40.7 & 31.2 & 126.8 & 135.7 & 118.2 & 131.7 & 141.5 & 122.2 \\
\hline 0.50 & 7.50 & 21.5 & 27.0 & 16.0 & 90.9 & 109.2 & 74.0 & 93.4 & 112.1 & 75.7 \\
\hline 0.60 & 9.00 & 14.5 & 21.3 & 6.7 & 68.3 & 92.2 & 43.1 & 69.8 & 94.3 & 43.8 \\
\hline
\end{tabular}

\subsubsection{Hydraulic loads}

The hydraulic loads acting on the modified valve are listed in Table 19 and Table 20. These values are calculated using Equations 6, 23, and 24. For the $51 \mathrm{ft}$ lift, the vertical hydraulic load decreases rather linearly throughout the entire valve opening over a range of $39.8 \mathrm{kips}$ of uplift (at $\mathrm{b} / \mathrm{B}=0.80$ ) to $57.6 \mathrm{kips}$ of downpull (at $\mathrm{b} / \mathrm{B}=0.15$ ). For the $59 \mathrm{ft}$ lift, the mean vertical hydraulic force varies between 86.5 kips of downpull (at b/B $=0.10$ ) and $14.6 \mathrm{kips}$ of uplift $(\mathrm{at} \mathrm{b} / \mathrm{B}=0.60$ ). The longitudinal hydraulic 
loads generally decrease during the valve opening and show a more noticeable decrease above $\mathrm{b} / \mathrm{B}=0.40$. For the $51 \mathrm{ft}$ lift, the mean longitudinal hydraulic load extends from $242.1 \mathrm{kips}$ ( $\mathrm{at} \mathrm{b} / \mathrm{B}=0.15$ ) to 22.5 kips (at b/B = 0.60). For the $59 \mathrm{ft} \mathrm{lift,} \mathrm{range} \mathrm{is} 286.8 \mathrm{kips}$ (at b/B $=0.15$ to 136.2 kips (at $\mathrm{b} / \mathrm{B}=0.80$ ). For the $51 \mathrm{ft}$ lift, the mean resultant hydraulic load is 248.9 kips (at b/B $=0.15$ ) to 46 kips (at b/B $=0.80$ ). For the $59 \mathrm{ft}$ lift, the range is $297.2 \mathrm{kips}(\mathrm{at} \mathrm{b} / \mathrm{B}=0.10$ ) to $137.3 \mathrm{kips}(\mathrm{at} \mathrm{b} / \mathrm{B}=0.60$ ). Plots of the experimental results are included in Appendix $\mathrm{B}$.

The values for the variables used in Equation 5 for this resultant force are listed in Table 21. Illustrations of the lines of action for the resultant hydraulic forces (Equations 8 through 11) for each valve position are shown in Figure $36 \mathrm{for}$ the $51 \mathrm{ft}$ lift and in Figure 37 for the $59 \mathrm{ft}$ lift. Positive slope values correspond to positive vertical hydraulic forces. These plots show how the vertical hydraulic force turns from downpull (negative) to uplift (positive).

Table 19. Modified valve hydraulic loads $-51 \mathrm{ft}$ lift.

\begin{tabular}{|c|c|c|c|c|c|c|c|c|c|c|}
\hline \multirow{2}{*}{$\begin{array}{c}\text { Valve } \\
\text { Position }\end{array}$} & \multirow{2}{*}{$\begin{array}{c}\text { Valve } \\
\text { Position } \\
\text {, b/B }\end{array}$} & \multicolumn{3}{|c|}{$\begin{array}{c}\text { Vertical Hydraulic Load } \\
\text { (kips) }\end{array}$} & \multicolumn{3}{|c|}{$\begin{array}{c}\text { Longitudinal Hydraulic } \\
\text { Load (kips) }\end{array}$} & \multicolumn{3}{|c|}{$\begin{array}{c}\text { Resultant Hydraulic } \\
\text { Load (kips) }\end{array}$} \\
\cline { 6 - 12 } & Mean & Max & Min & Mean & Max & Min & Mean & Max & Min \\
\hline 0.15 & 2.25 & -57.6 & -37.8 & -74.4 & 242.1 & 271.7 & 213.1 & 248.9 & 280.2 & 216.7 \\
\hline 0.20 & 3.00 & -28.5 & -10.5 & -41.6 & 186.3 & 209.0 & 160.6 & 188.6 & 212.8 & 161.4 \\
\hline 0.25 & 3.75 & -27.9 & -13.5 & -39.5 & 195.2 & 214.4 & 174.9 & 197.2 & 217.6 & 175.6 \\
\hline 0.30 & 4.50 & -23.3 & -9.1 & -35.4 & 194.2 & 208.9 & 173.4 & 195.6 & 211.4 & 173.7 \\
\hline 0.35 & 5.25 & -15.7 & -2.1 & -27.8 & 182.2 & 198.3 & 164.6 & 182.9 & 200.1 & 164.6 \\
\hline 0.40 & 6.00 & -9.7 & 4.3 & -21.7 & 173.6 & 192.5 & 151.3 & 173.9 & 193.3 & 151.3 \\
\hline 0.50 & 7.50 & 10.1 & 26.9 & -6.2 & 124.3 & 161.1 & 95.1 & 124.9 & 161.2 & 97.2 \\
\hline 0.60 & 9.00 & 22.5 & 39.3 & 5.6 & 89.8 & 128.5 & 50.7 & 92.9 & 129.1 & 59.1 \\
\hline 0.80 & 12.00 & 39.8 & 50.4 & 29.6 & 22.5 & 42.6 & 4.4 & 46.0 & 57.8 & 35.6 \\
\hline
\end{tabular}


Table 20. Modified valve hydraulic loads $-59 \mathrm{ft}$ lift.

\begin{tabular}{|c|c|c|c|c|c|c|c|c|c|c|}
\hline \multirow{2}{*}{$\begin{array}{c}\text { Valve } \\
\text { Position }\end{array}$} & \multirow{2}{*}{$\begin{array}{c}\text { Valve } \\
\text { Position } \\
\text { b/ }\end{array}$} & \multicolumn{3}{|c|}{$\begin{array}{c}\text { Vertical Hydraulic Load } \\
\text { (kips) }\end{array}$} & \multicolumn{3}{|c|}{$\begin{array}{c}\text { Longitudinal Hydraulic } \\
\text { Load (kips) }\end{array}$} & \multicolumn{3}{|c|}{$\begin{array}{c}\text { Resultant Hydraulic } \\
\text { Load (kips) }\end{array}$} \\
\cline { 6 - 12 } & Mean & Max & Min & Mean & Max & Min & Mean & Max & Min \\
\hline 0.10 & 1.50 & -86.5 & -75.3 & -97.4 & 284.3 & 299.5 & 273.1 & 297.2 & 313.7 & 284.4 \\
\hline 0.15 & 2.25 & -74.0 & -62.4 & -85.6 & 286.8 & 301.0 & 275.7 & 296.3 & 311.9 & 282.6 \\
\hline 0.20 & 3.00 & -55.7 & -42.1 & -68.0 & 261.3 & 277.8 & 242.0 & 267.2 & 285.3 & 246.1 \\
\hline 0.25 & 3.75 & - & - & - & - & - & - & - & - & - \\
\hline 0.30 & 4.50 & - & - & - & - & - & - & - & - & - \\
\hline 0.35 & 5.25 & -40.6 & -30.0 & -51.4 & 266.2 & 283.3 & 249.7 & 269.3 & 287.8 & 251.9 \\
\hline 0.40 & 6.00 & -33.1 & -22.1 & -44.1 & 253.6 & 271.5 & 236.3 & 255.7 & 274.5 & 237.5 \\
\hline 0.50 & 7.50 & -2.6 & 12.8 & -18.9 & 181.6 & 218.5 & 147.4 & 181.7 & 218.9 & 148.0 \\
\hline 0.60 & 9.00 & 14.6 & 35.3 & -3.7 & 136.2 & 184.3 & 85.7 & 137.3 & 184.3 & 90.3 \\
\hline
\end{tabular}

Table 21. Modified valve hydraulic force line of action values, both lifts.

\begin{tabular}{|c|c|c|c|c|c|c|}
\hline \multirow[b]{2}{*}{ 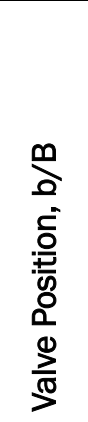 } & \multicolumn{3}{|c|}{$51 \mathrm{ft}$ Lift } & \multicolumn{3}{|c|}{$59 \mathrm{ft}$ Lift } \\
\hline & 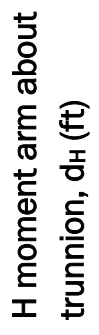 & 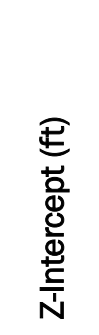 & $\begin{array}{l}\varepsilon \\
\Phi \\
\frac{0}{\omega}\end{array}$ & 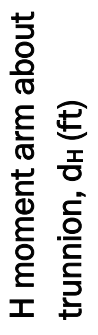 & 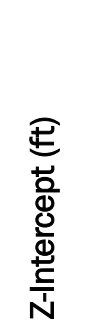 & $\begin{array}{l}\varepsilon \\
\text { \& } \\
\frac{0}{0}\end{array}$ \\
\hline 0.15 & 2.2 & -2.3 & -0.24 & 1.8 & -1.9 & -0.31 \\
\hline 0.20 & 2.9 & -2.9 & -0.15 & 2.0 & -2.1 & -0.26 \\
\hline 0.25 & 2.8 & -2.8 & -0.14 & 2.2 & -2.2 & -0.21 \\
\hline 0.30 & 2.7 & -2.7 & -0.12 & - & - & - \\
\hline 0.35 & 3.0 & -3.0 & -0.09 & - & - & - \\
\hline 0.40 & 3.0 & -3.0 & -0.06 & 2.1 & -2.1 & -0.15 \\
\hline 0.50 & 4.7 & -4.7 & 0.08 & 2.3 & -2.3 & -0.13 \\
\hline 0.60 & 6.8 & -7.1 & 0.26 & 3.3 & -3.3 & 0.00 \\
\hline 0.80 & 14.1 & -29.6 & 1.78 & 5.0 & -5.1 & 0.13 \\
\hline
\end{tabular}


Figure 36. Modified valve resultant hydraulic force line of action $-51 \mathrm{ft} \mathrm{lift.}$

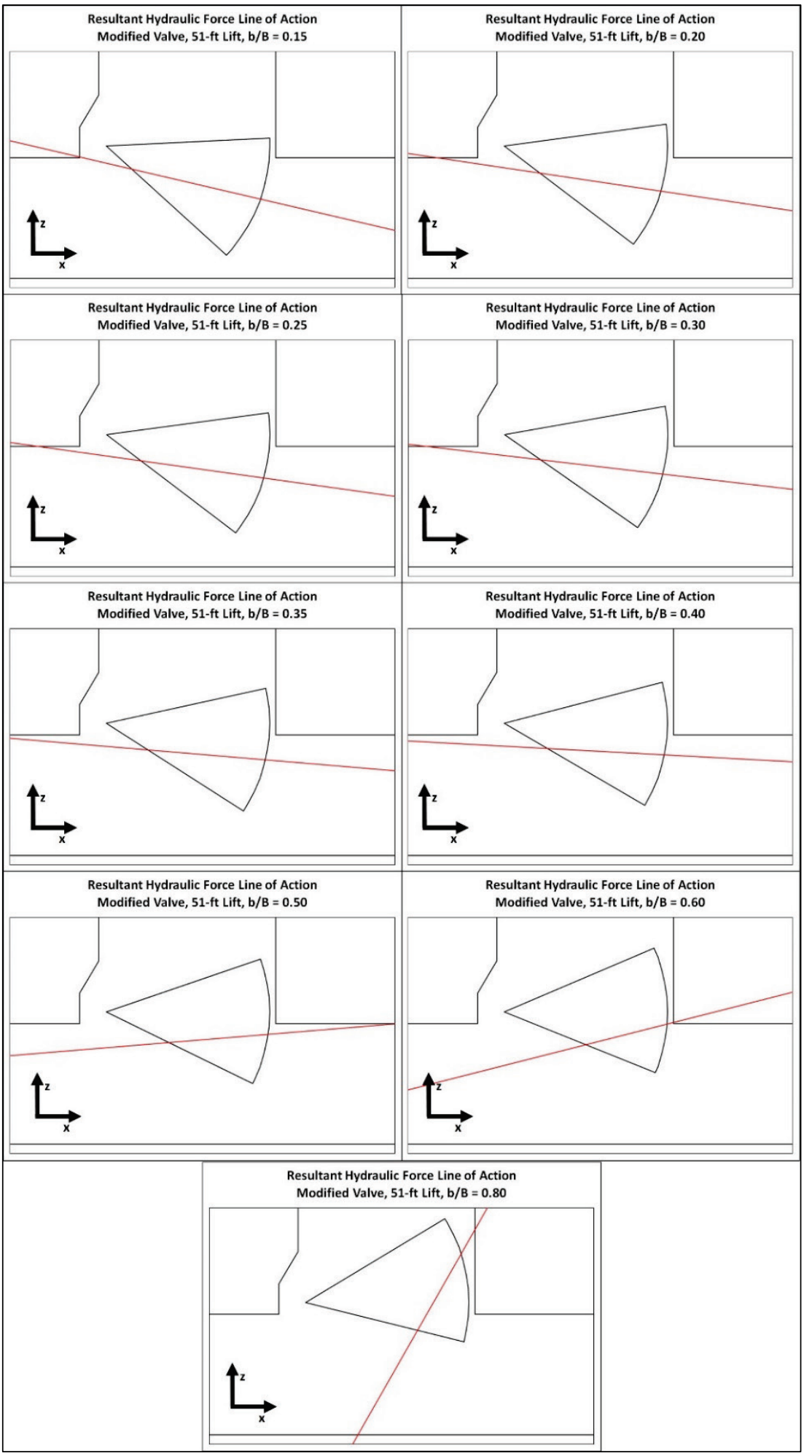


Figure 37. Modified valve resultant hydraulic force line of action $-59 \mathrm{ft}$ lift.

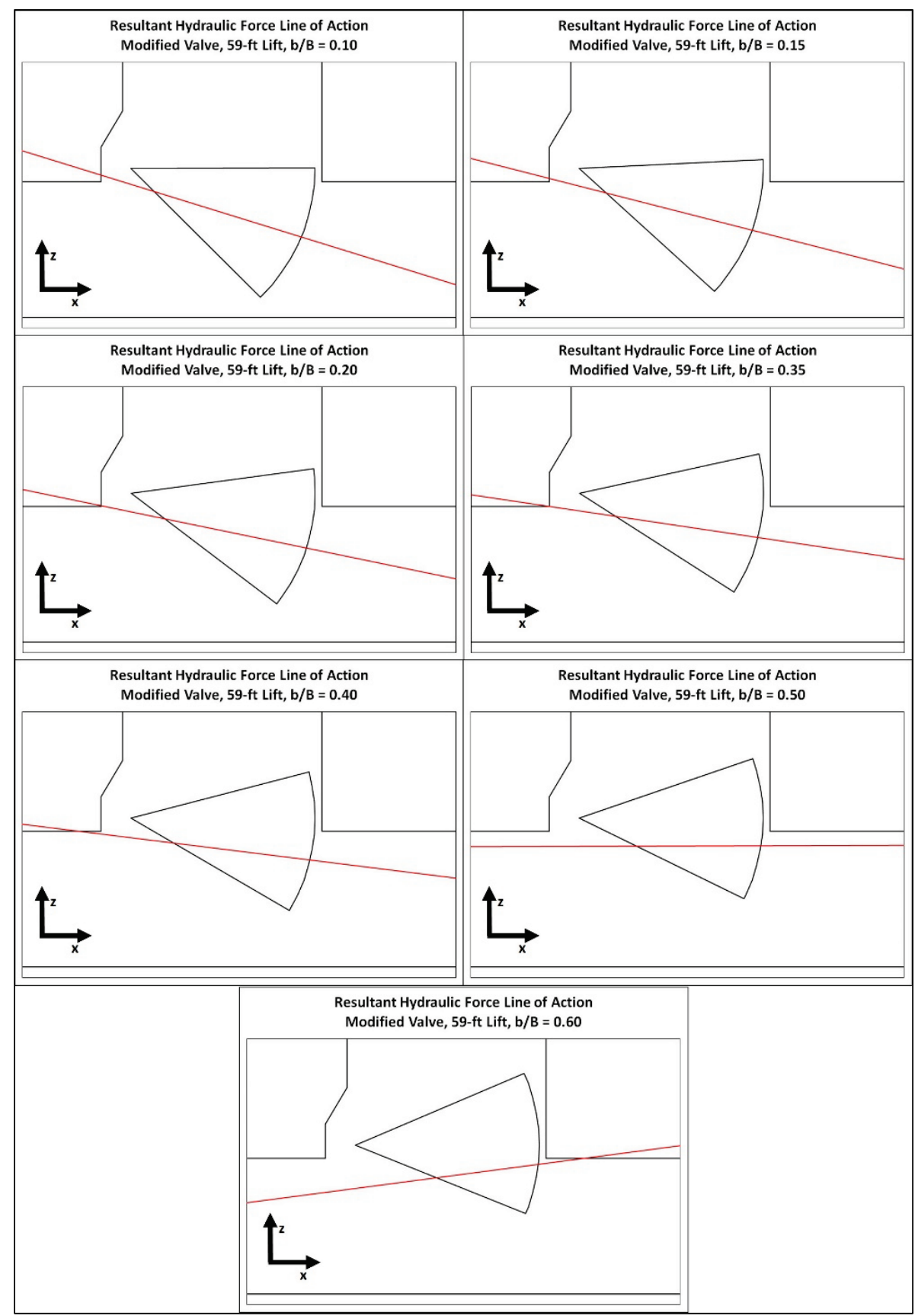

\subsubsection{Pressure}

The pressure for each piezometer along the culvert during the modified valve experiments are shown in Table 22 and Table 23. Plots of these values in the scaled culvert section of the facility are included in Appendix B. The pressure head begins near the upper pool elevation but drops dramatically across the valve (from Piezometer 4 to Piezometer 5 ). Downstream of Piezometer 5 , the pressure head recovers and is much more pronounced at 
valve positions above $\mathrm{b} / \mathrm{B}=0.20$. For the $51 \mathrm{ft}$ lift, the pressure head is a minimum mean value of $350.6 \mathrm{ft}(\mathrm{at} \mathrm{b} / \mathrm{B}=0.35$ ), and for a $59 \mathrm{ft}$ lift, the pressure head is a minimum value of $331.7 \mathrm{ft}(\mathrm{at} \mathrm{b} / \mathrm{B}=0.35)$.

Table 22. Modified valve pressures in feet of prototype elevation - $51 \mathrm{ft} \mathrm{lift.}$

\begin{tabular}{|c|c|c|c|c|c|c|c|c|c|c|c|}
\hline \multicolumn{2}{|c|}{$\begin{array}{c}\text { Valve Position } \\
\text { b/B }\end{array}$} & \multirow{2}{*}{$\frac{0.10}{-}$} & \multirow{2}{*}{$\begin{array}{c}0.15 \\
409.1\end{array}$} & \multirow{2}{*}{$\begin{array}{c}0.20 \\
408.7\end{array}$} & \multirow{2}{*}{$\begin{array}{c}0.25 \\
408.3\end{array}$} & \multirow{2}{*}{$\begin{array}{c}0.30 \\
407.6\end{array}$} & \multirow{2}{*}{$\begin{array}{c}0.35 \\
406.9\end{array}$} & \multirow{2}{*}{$\begin{array}{c}0.40 \\
405.9\end{array}$} & \multirow{2}{*}{$\frac{0.50}{403.8}$} & \multirow{2}{*}{$\frac{0.60}{401.8}$} & \multirow{2}{*}{$\begin{array}{c}0.80 \\
398.6\end{array}$} \\
\hline & Mean & & & & & & & & & & \\
\hline \multirow[b]{2}{*}{ Piez. 1} & Max. & - & 409.3 & 408.7 & 408.3 & 407.6 & 406.9 & 405.9 & 403.8 & 401.8 & 398.6 \\
\hline & Min. & - & 409.0 & 408.7 & 408.3 & 407.6 & 406.9 & 405.9 & 403.8 & 401.8 & 398.6 \\
\hline \multirow[b]{3}{*}{ Piez. 2} & Mean & - & 409.1 & 408.7 & 408.4 & 407.5 & 406.9 & 405.8 & 403.7 & 401.7 & 398.5 \\
\hline & Max. & - & 409.3 & 408.7 & 408.7 & 407.6 & 406.9 & 405.8 & 403.7 & 401.7 & 398.5 \\
\hline & Min. & - & 409.0 & 408.7 & 408.3 & 407.5 & 406.8 & 405.8 & 403.7 & 401.7 & 398.5 \\
\hline \multirow[b]{3}{*}{ Piez. 3} & Mean & - & 408.7 & 408.5 & 408.1 & 407.2 & 406.6 & 405.2 & 402.9 & 400.8 & 398.0 \\
\hline & Max. & - & 409.1 & 408.6 & 408.1 & 407.4 & 406.7 & 405.5 & 403.2 & 401.0 & 398.0 \\
\hline & Min. & - & 408.0 & 408.5 & 408.0 & 407.0 & 406.3 & 405.0 & 402.5 & 400.7 & 398.0 \\
\hline \multirow[b]{3}{*}{ Piez. 4} & Mean & - & 350.6 & 361.1 & 357.9 & 355.6 & 357.2 & 357.9 & 366.1 & 375.2 & 388.3 \\
\hline & Max. & - & 352.2 & 362.6 & 358.4 & 356.0 & 358.6 & 358.0 & 369.5 & 375.3 & 389.2 \\
\hline & Min. & - & 348.5 & 360.0 & 357.3 & 355.0 & 356.5 & 357.7 & 360.0 & 375.0 & 387.8 \\
\hline \multirow[b]{3}{*}{ Piez. 5} & Mean & - & 350.0 & 360.4 & 356.9 & 353.4 & 353.3 & 351.7 & 359.2 & 364.7 & 386.6 \\
\hline & Max. & - & 351.5 & 362.0 & 357.5 & 353.7 & 354.9 & 352.0 & 359.5 & 364.8 & 386.8 \\
\hline & Min. & - & 348.0 & 359.3 & 356.6 & 353.0 & 352.5 & 351.5 & 358.8 & 364.5 & 386.1 \\
\hline \multirow[b]{3}{*}{ Piez. 6} & Mean & - & 349.7 & 360.6 & 356.6 & 353.2 & 353.0 & 351.7 & 359.8 & 367.0 & 388.8 \\
\hline & Max. & - & 351.0 & 362.2 & 357.0 & 353.3 & 354.5 & 351.9 & 360.0 & 367.0 & 389.5 \\
\hline & Min. & - & 347.8 & 359.8 & 356.4 & 353.0 & 352.3 & 351.5 & 359.5 & 367.0 & 388.0 \\
\hline \multirow[b]{3}{*}{ Piez. 7} & Mean & - & 353.9 & 363.8 & 361.3 & 358.2 & 357.8 & 358.3 & 372.4 & 378.2 & 393.8 \\
\hline & Max. & - & 355.5 & 365.0 & 361.7 & 358.5 & 359.8 & 358.5 & 377.1 & 378.6 & 394.2 \\
\hline & Min. & - & 352.3 & 362.0 & 360.8 & 358.0 & 356.5 & 357.9 & 370.0 & 378.0 & 393.4 \\
\hline \multirow[b]{3}{*}{ Piez. 8} & Mean & - & 358.1 & 369.5 & 368.2 & 367.4 & 368.6 & 369.4 & 376.9 & 383.1 & 394.3 \\
\hline & Max. & - & 359.5 & 370.9 & 368.4 & 367.7 & 370.0 & 369.5 & 378.0 & 383.3 & 395.0 \\
\hline & Min. & - & 356.7 & 368.5 & 368.0 & 367.0 & 367.2 & 369.2 & 375.0 & 383.0 & 394.0 \\
\hline \multirow[b]{3}{*}{ Piez. 9} & Mean & - & 409.2 & 409.0 & 408.9 & 407.7 & 406.7 & 405.5 & 403.4 & 400.3 & 395.9 \\
\hline & Max. & - & 409.3 & 409.0 & 409.2 & 407.8 & 406.9 & 405.7 & 403.6 & 400.8 & 396.3 \\
\hline & Min. & - & 409.1 & 408.9 & 408.6 & 407.5 & 406.5 & 405.3 & 403.2 & 399.8 & 395.3 \\
\hline
\end{tabular}


Table 23. Modified valve pressures in feet of prototype elevation - $59 \mathrm{ft} \mathrm{lift}$.

\begin{tabular}{|c|c|c|c|c|c|c|c|c|c|c|c|}
\hline \multicolumn{2}{|c|}{$\begin{array}{c}\text { Valve Position } \\
\text { b/B }\end{array}$} & \multirow{2}{*}{$\frac{0.10}{412.8}$} & \multirow{2}{*}{$\begin{array}{c}0.15 \\
412.7\end{array}$} & \multirow{2}{*}{$\frac{0.20}{411.8}$} & \multirow{2}{*}{$\frac{0.25}{-}$} & \multirow{2}{*}{$\frac{0.30}{-}$} & \multirow{2}{*}{$\frac{0.35}{409.0}$} & \multirow{2}{*}{$\begin{array}{l}0.40 \\
407.7\end{array}$} & \multirow{2}{*}{$\frac{0.50}{404.8}$} & \multirow{2}{*}{$\frac{0.60}{401.6}$} & \multirow{2}{*}{$\frac{0.80}{-}$} \\
\hline \multirow{3}{*}{$\begin{array}{c}\text { Piez. } \\
1\end{array}$} & Mean & & & & & & & & & & \\
\hline & Max. & 413.0 & 412.8 & 411.8 & - & - & 409.0 & 407.7 & 404.8 & 401.6 & - \\
\hline & Min. & 412.7 & 412.4 & 411.8 & - & - & 409.0 & 407.7 & 404.8 & 401.6 & - \\
\hline \multirow{3}{*}{$\begin{array}{c}\text { Piez. } \\
2\end{array}$} & Mean & 412.8 & 412.7 & 411.7 & - & - & 409.0 & 407.6 & 404.7 & 401.5 & - \\
\hline & Max. & 413.0 & 412.8 & 411.8 & - & - & 409.0 & 407.6 & 404.8 & 401.5 & - \\
\hline & Min. & 412.7 & 412.4 & 411.7 & - & - & 408.9 & 407.6 & 404.7 & 401.5 & - \\
\hline \multirow{3}{*}{$\begin{array}{c}\text { Piez. } \\
3\end{array}$} & Mean & 412.8 & 412.5 & 411.6 & - & - & 408.2 & 407.0 & 404.0 & 400.7 & - \\
\hline & Max. & 413.0 & 412.7 & 411.6 & - & - & 408.4 & 407.0 & 404.0 & 400.8 & - \\
\hline & Min. & 412.7 & 412.2 & 411.6 & - & - & 408.0 & 406.9 & 404.0 & 400.5 & - \\
\hline \multirow{3}{*}{$\begin{array}{c}\text { Piez. } \\
4\end{array}$} & Mean & 347.6 & 344.6 & 348.1 & - & - & 338.3 & 339.8 & 355.3 & 362.9 & - \\
\hline & Max. & 348.6 & 345.5 & 350.0 & - & - & 340.0 & 341.0 & 356.0 & 363.4 & - \\
\hline & Min. & 346.8 & 344.0 & 345.0 & - & - & 336.0 & 338.5 & 354.5 & 362.0 & - \\
\hline \multirow{3}{*}{$\begin{array}{c}\text { Piez. } \\
5\end{array}$} & Mean & 346.7 & 343.5 & 345.4 & - & - & 332.0 & 331.7 & 340.4 & 347.0 & - \\
\hline & Max. & 347.5 & 344.0 & 348.7 & - & - & 333.0 & 333.0 & 341.2 & 347.7 & - \\
\hline & Min. & 346.2 & 343.0 & 343.6 & - & - & 330.0 & 330.0 & 339.0 & 345.6 & - \\
\hline \multirow{3}{*}{$\begin{array}{c}\text { Piez. } \\
6\end{array}$} & Mean & 347.2 & 343.4 & 345.1 & - & - & 333.0 & 331.7 & 341.5 & 354.3 & - \\
\hline & Max. & 348.2 & 343.8 & 348.0 & - & - & 333.0 & 333.0 & 343.0 & 360.2 & - \\
\hline & Min. & 346.3 & 342.8 & 343.4 & - & - & 333.0 & 330.0 & 340.0 & 351.3 & - \\
\hline \multirow{3}{*}{$\begin{array}{c}\text { Piez. } \\
7\end{array}$} & Mean & 352.5 & 346.9 & 351.3 & - & - & 339.0 & 339.0 & 356.7 & 368.6 & - \\
\hline & Max. & 353.7 & 348.5 & 352.5 & - & - & 340.0 & 341.0 & 357.2 & 369.5 & - \\
\hline & Min. & 351.5 & 344.0 & 349.3 & - & - & 338.0 & 338.0 & 356.0 & 368.0 & - \\
\hline \multirow{3}{*}{$\begin{array}{c}\text { Piez. } \\
8\end{array}$} & Mean & 355.4 & 353.6 & 359.0 & - & - & 354.2 & 355.4 & 367.4 & 374.7 & - \\
\hline & Max. & 358.5 & 354.3 & 360.4 & - & - & 354.9 & 356.3 & 368.0 & 375.2 & - \\
\hline & Min. & 353.0 & 353.0 & 356.3 & - & - & 353.7 & 355.0 & 367.0 & 374.0 & - \\
\hline \multirow{3}{*}{$\begin{array}{c}\text { Piez. } \\
9\end{array}$} & Mean & 412.8 & 412.7 & 412.0 & - & - & 408.7 & 407.2 & 403.1 & 399.0 & - \\
\hline & Max. & 413.1 & 413.0 & 412.0 & - & - & 408.8 & 407.3 & 403.2 & 399.9 & - \\
\hline & Min. & 412.7 & 412.4 & 412.0 & - & - & 408.5 & 407.0 & 403.0 & 398.5 & - \\
\hline
\end{tabular}




\section{Comparison of Valve Performance}

A thorough discussion of the performance of each valve, information about the design of the next Pickwick Lock culvert valve, and a comparison of the valves are included in this chapter. The data supporting the descriptions drawn from the model testing are included in Chapter 4 .

Two major operational concerns of the replacement lock culvert valves are the following:

- Will the new valve be able to sustain (structurally) the loads during operation, at least as well as the existing valve?

- Will the new valve produce loads that the associated equipment, such as the lift mechanism machinery, cannot withstand?

These concerns are equally important and should both be considered before a final decision is made on the final replacement valve design. Once these two criteria are taken into account, a design can be produced that will require less maintenance and will have a longer service life than the existing valve.

The structural concerns for the valve can be separated into two different aspects: overload and fatigue. The overload concerns correspond to choices of absolute material strength, which are directly related to the maximum loads the valve experiences while in service. The fatigue considerations refer to load variations, which can be inferred from the maximum and minimum loads the valve experiences while in service.

\subsection{Valve performance - flow behavior}

Dye released upstream of each valve indicates that both produce generally the same flow patterns. The downstream bulkhead slot flow fluctuates significantly with both valves at or above $b / B \geq 0.50$. At these high valve positions, both valves have higher rigid-body vibrations than lower valve positions.

\subsection{Valve performance - load magnitudes}

The measurements from each experiment provide sufficient information to determine the maximum loads the valve is likely to experience during a filling and emptying operation. Once the maximum loads that the valve 
experiences are understood, the new valve can be properly designed to withstand the operating loads. These values are listed in Table 4 through Table 10 for the existing valve and in Table 14 through Table 20 for the modified valve. Plots for these values are included in Appendices A and B. The $59 \mathrm{ft}$ lift flow conditions are the focus of this section because they generally provide the most extreme operating conditions for the valve.

The hoist loads provide an indication of how much force the valve lift mechanism must produce in the lower strut to lift or lower the tainter gate during a filling and emptying operation. The existing valve's maximum hoist load is $24.7 \mathrm{kips}$ in tension ( $\mathrm{at} \mathrm{b} / \mathrm{B}=0.20$ ) and $26.1 \mathrm{kips}$ in compression ( $\mathrm{at} \mathrm{b} / \mathrm{B}=0.60$ ). The maximum hoist load is reduced dramatically once the valve is raised to $\mathrm{b} / \mathrm{B}=0.30$ and remains quite steady throughout the remainder of the valve opening. In the modified valve, the removal of the top plate and the skin plate stiffeners reduces the mean hoist loads to a maximum of 6.8 kips in tension ( $\mathrm{at} \mathrm{b} / \mathrm{B}=0.35$ ) and 10.4 kips in compression ( $\mathrm{at} \mathrm{b} / \mathrm{B}=0.60$ ). The modified valve mean hoist load varies much less throughout the valve opening than the existing valve. These reduced hoist loads indicate that the existing lift mechanism is sufficient for the modified valve.

The trunnion loads indicate how much force the trunnion and the trunnion anchors must withstand during a filling and emptying operation. Since each trunnion anchor must withstand the trunnion load at each end, the resultant trunnion end loads are discussed. The existing valve has a maximum trunnion end load of $101.5 \mathrm{kips}(\mathrm{at} \mathrm{b} / \mathrm{B}=0.10$ ) while the modified valve produces a maximum trunnion end load of 163.9 kips (at $\mathrm{b} / \mathrm{B}=0.10$ ). The resultant trunnion end load for the modified valve is caused by the large longitudinal trunnion end load. These higher end loads indicate that the trunnion pins and anchors for the modified valve must be significantly stronger than the existing ones. These increased loads will require that the components be redesigned if the modified valve is used for the new prototype valve. The higher trunnion end loads occur at the lower valve openings, the lowest in use for this experiment being $\mathrm{b} / \mathrm{B}=0.10$. The trunnion end load at $\mathrm{b} / \mathrm{B}=0.10$ can account for the expected loads for even smaller valve openings with slight increases.

The hydraulic loads provide the best indication of the loads produced by valve shape. The dry loads are removed for all calculations to ensure that the hydraulic loads are as independent of the valve weight as possible. The 
hydraulic loads produce the reaction loads that support and control the valve. Consequently, the hydraulic loads are the best information to use to determine the reaction loads (hoist and trunnion) that will be produced by the prototype valve. Unlike the trunnion (and trunnion end) loads, the individual hydraulic load components are quite relevant for design purposes. The vertical hydraulic load determines whether the valve (and subsequently the lower strut of the valve lift mechanism) is being pulled upward or downward during a filling and emptying operation. However, the longitudinal hydraulic load does not offer such direct insights into the valve motion. The resultant hydraulic load (defined in Equation 6 and used in Equation 12) is used - in conjunction with the hydraulic load components - to determine the line of action of the hydraulic force as indicated in Section 2.2. The vertical hydraulic load for the existing valve varies from 83.7 kips of downpull and $43.8 \mathrm{kips}$ of uplift whereas for the modified valve the vertical hydraulic load varies from 97.4 kips of downpull to 35.3 kips of uplift. The mean vertical hydraulic load increases some (but not dramatically) for the modified valve. The longitudinal hydraulic load for the existing valve (between 172.5 and 20.3 kips) is significantly lower than the mean hydraulic longitudinal load for the modified valve (301.0 to 90.3 kips). The modified valve shape produces much higher hydraulic loads, most likely due to the flow along the skin plate having significantly less resistance. This higher hydraulic load is transferred into the load the trunnion ends must withstand.

\subsection{Valve performance - load variation}

In addition to the loads that the valve experiences during a filling and emptying operation, the valve must be able to withstand the variation of those loads. This load variation is directly related to the vibration potential of a valve during the filling and emptying operation. The load frequency is not reported because Froudian models of this scale do not produce scalable vibration measurements. To provide direct insight into the load variation each valve experiences, plots derived from the load measurement plots presented in Chapter 4 are included in Appendix C. Smaller values indicate lower valve vibration and potentially longer service life. The load variation plots collectively indicate that the modified valve has either relatively similar load variations or lower load variations. Such behavior indicates that the modified valve design experiences lower vibration intensity during a filling and emptying operation. 


\section{Summary and Recommendations}

The focus of this study is to provide quantitative results to determine a new valve design. This design provides lower operation and maintenance costs. The study also provides results to properly design operational machinery for the valve and the structures (such as trunnion anchors) supporting the valve. The existing valve is an open-framed (vertically framed) design. The proposed replacement valve design (modified valve) is open-framed (vertically framed) including modifications to provide longer service life and reduce maintenance.

The experiments provide quantitative data on the hoist load, the trunnion load (the components of which align with the vertical and longitudinal components of the primary direction of flow in the culvert), and pressures along the culvert near the valve. The experimental results indicate that the hoist loads for the modified valve are lower than those of the existing valve. The variation in the hoist load is also lower with the modified valve. The results indicate that the valve lift machinery already installed at Pickwick Lock is sufficient for controlling the modified valve. Further, the load variation for the modified valve is lower than the existing valve. This indicates that the modified valve has a lower vibration potential (as a rigid body) than the existing valve. This lower vibration potential means that the valve lift machinery experiences lower hydraulically induced vibration amplitudes during filling and emptying operations.

The trunnion loads for the modified valve are significantly higher than those of the existing valve. The increase is primarily attributed to the increase in the longitudinal direction load. The variation in the trunnion load for the modified valve is lower at every valve position tested, except the highest valve positions. The lower load variation indicates that the prototype trunnion will have a longer fatigue life if the trunnion on the replacement valve is composed of a material with similar fatigue characteristics as the existing valve.

Hydraulic loads are the forces acting on the valve with the reaction load from the trunnion and the long strut removed. These loads provide insights into how valve shape alone affects the loads on the valve. The hydraulic loads can be used to predict the hoist and trunnion loads after expected minor changes such as the valve member thickness have been 
made to the design of the modified valve by using three equilibrium conditions (Equations 7, 9, and 11).

The experiment results show the modified Pickwick Lock culvert valve performs better hydraulically than the existing valve for the conditions tested. The modified valve produces significantly lower hoist loads and hoist load variation than the existing valve. The modified valve requires stronger trunnion pins and anchors, but the trunnion load variation is smaller with the modified valve than with the existing valve. The modified valve design is the recommended replacement valve based on study results and hydraulic considerations. 


\section{References}

Baines, W. D. 1954. Flow through Tainter Valves. Ottawa, Canada: National Research Laboratories.

Bislip-Morales, C. B., and J. E. Hite. 2013. Watts Bar Lock Valve Model Study. TR-13-12. Vicksburg, MS: U.S. Army Engineer Research and Development Center.

Headquarters, U.S. Army Corps of Engineers (HQUSACE). 1975. Hydraulic Design of Lock Culvert Valves. EM 1110-2-1610. Washington, DC.

Stockstill, R. L., E. A. Hammack, D. S. Smith, C. B. Bislip-Morales, K. Green, and J. M. Vaughan. 2015. Hydraulic Evaluation of Culvert Valves at Eisenhower and Snell Locks, St. Lawrence Seaway. ERDC/CHL TR-15-7. Vicksburg, MS: U.S. Army Engineer Research and Development Center. 


\section{Appendix A: Existing Valve Load Result Plots}

In this appendix, a description of each valve and the results of each experiment with the existing Pickwick Lock culvert valve are presented (Figures 38-59). The results include measured and calculated quantities. The forces acting on the valve - hoist, trunnion, and hydraulic - are presented in a series of plots. The results for each lift are included in separate plots, and each plot includes the mean, maximum, and minimum value for each valve position tested. Each set of results is obtained from three sets of valve experiments. The average, maximum, and minimum value (measured and calculated for each quantity) are recorded for each experiment. Then, the average, maximum, and minimum values for each test (average of averages, maximum of maxima, minimum of minima) are calculated and presented.

Figure 38. Existing valve hoist load $-51 \mathrm{ft} \mathrm{lift.}$

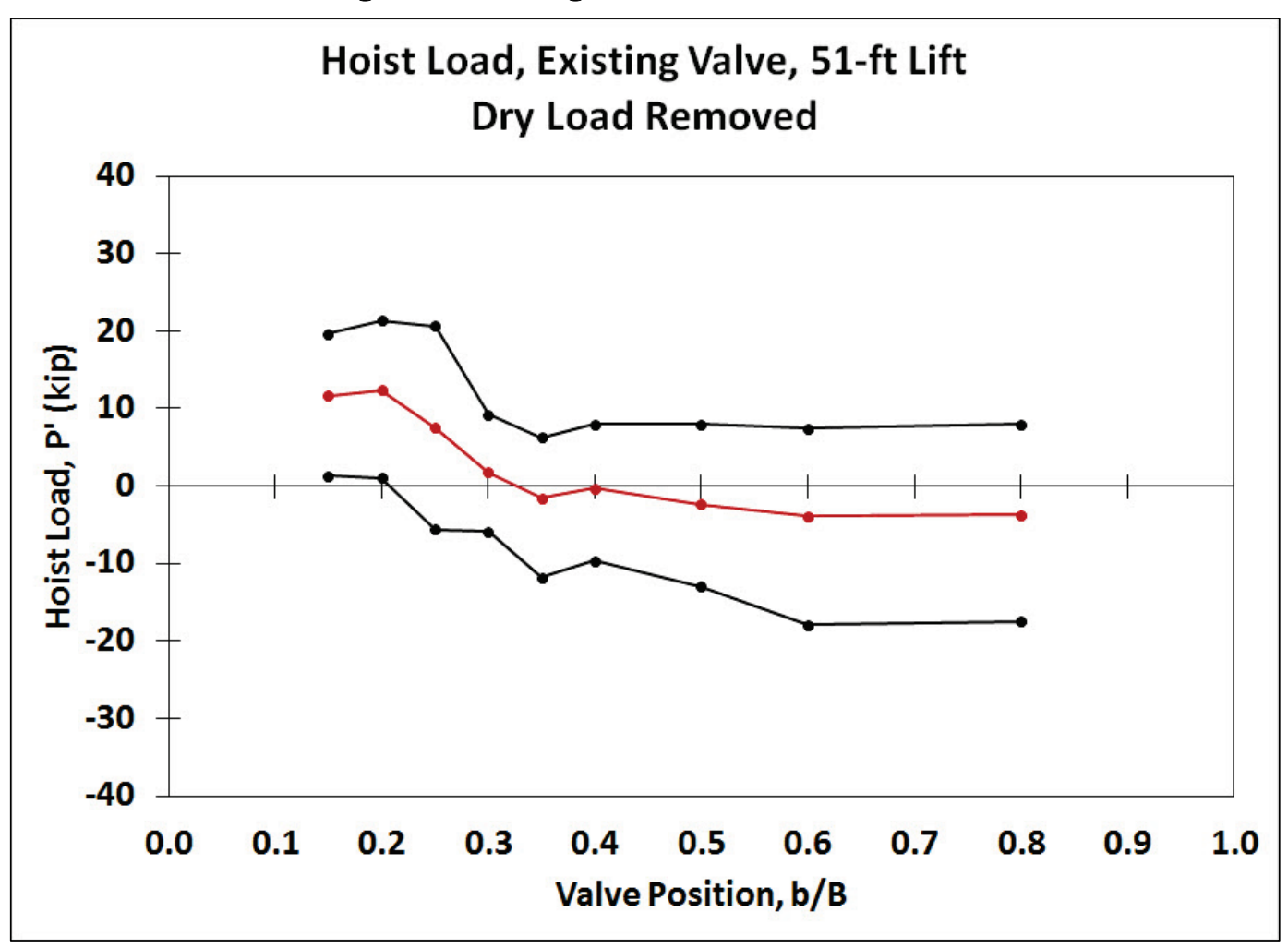


Figure 39. Existing valve hoist load $-59 \mathrm{ft}$ lift.

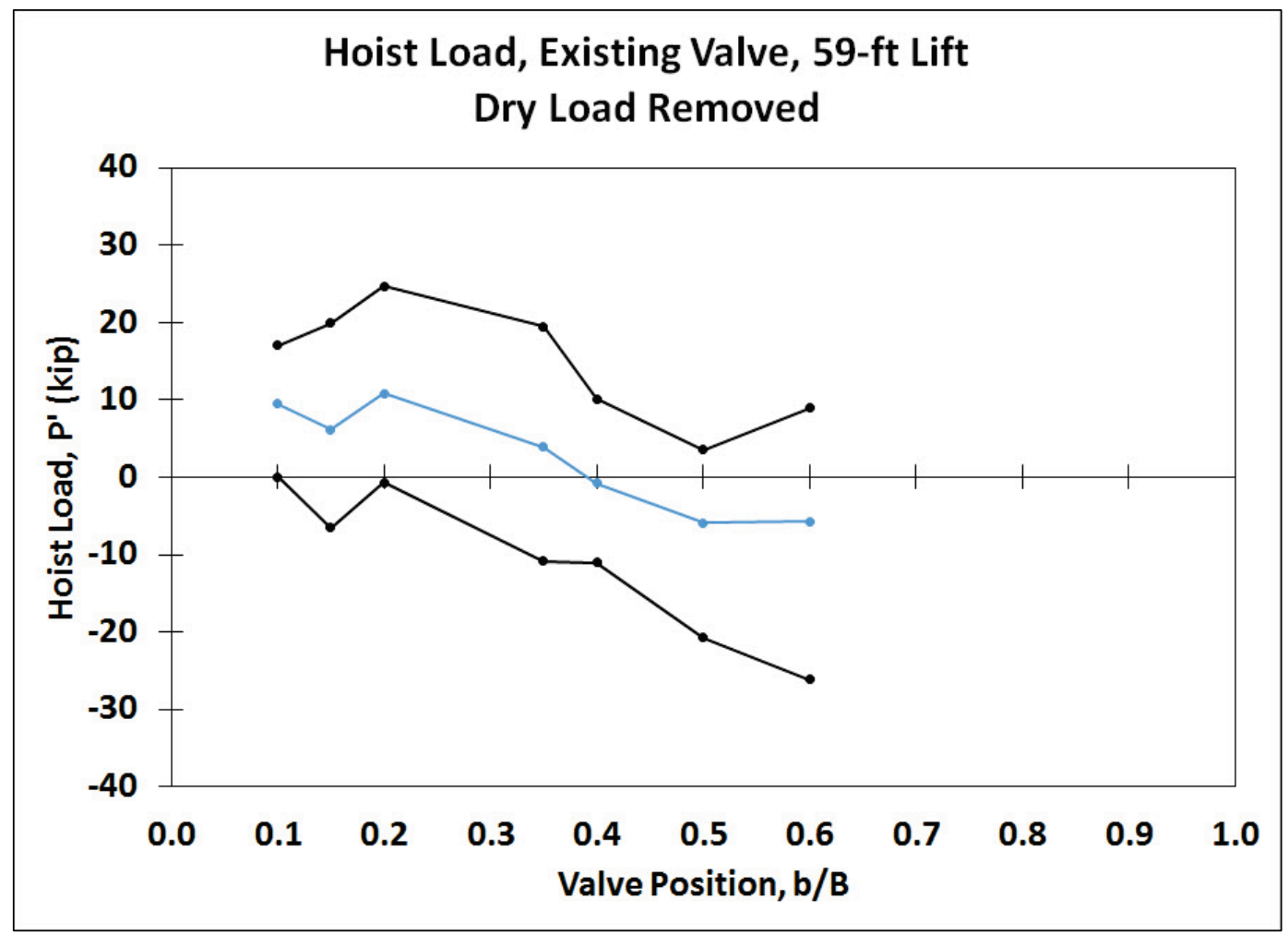

Figure 40. Existing valve vertical trunnion load $-51 \mathrm{ft}$ lift.

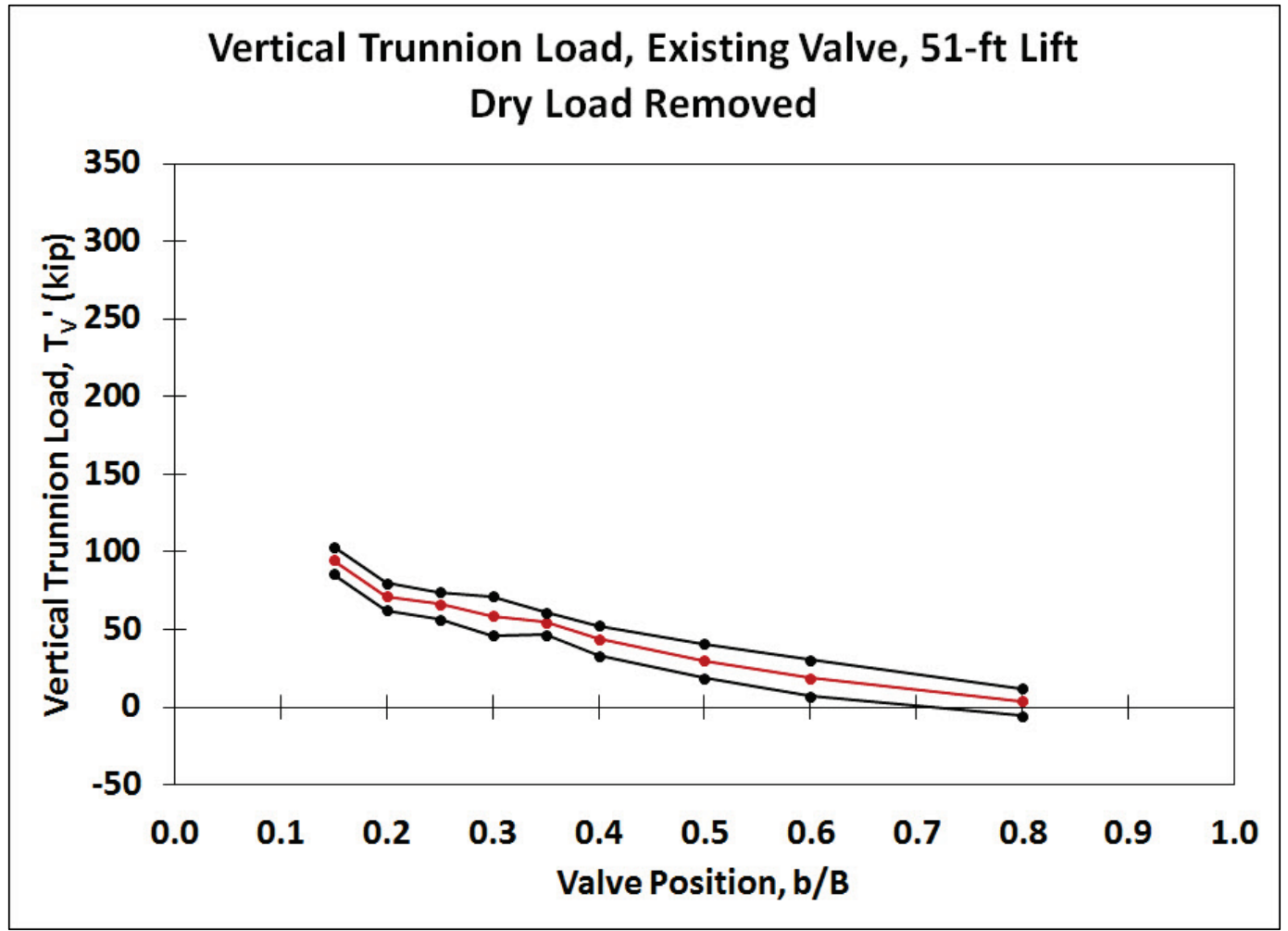


Figure 41. Existing valve vertical trunnion load $-59 \mathrm{ft}$ lift.

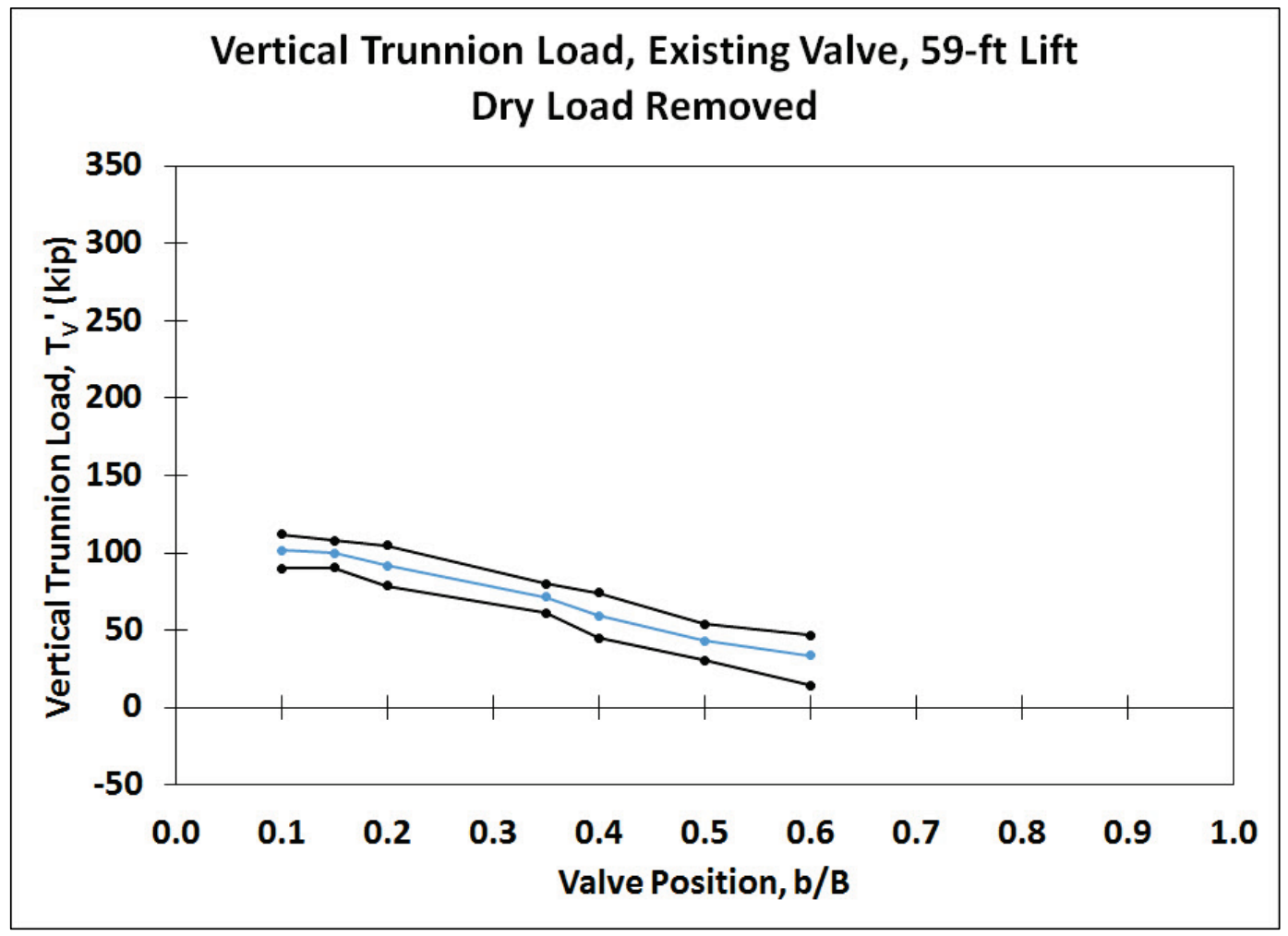

Figure 42. Existing valve longitudinal trunnion load $-51 \mathrm{ft} \mathrm{lift}$.

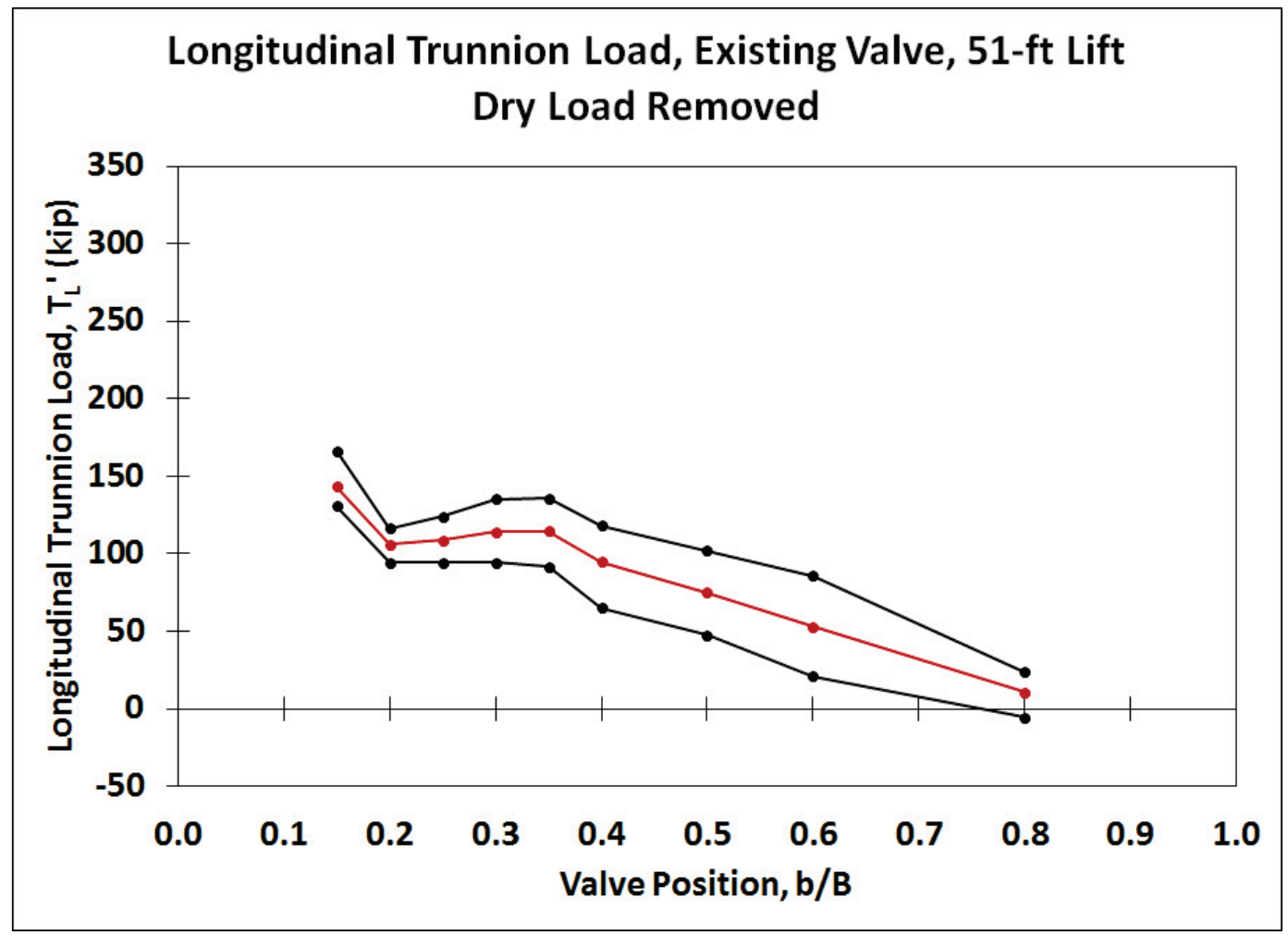


Figure 43. Existing valve longitudinal trunnion load $-59 \mathrm{ft}$ lift.

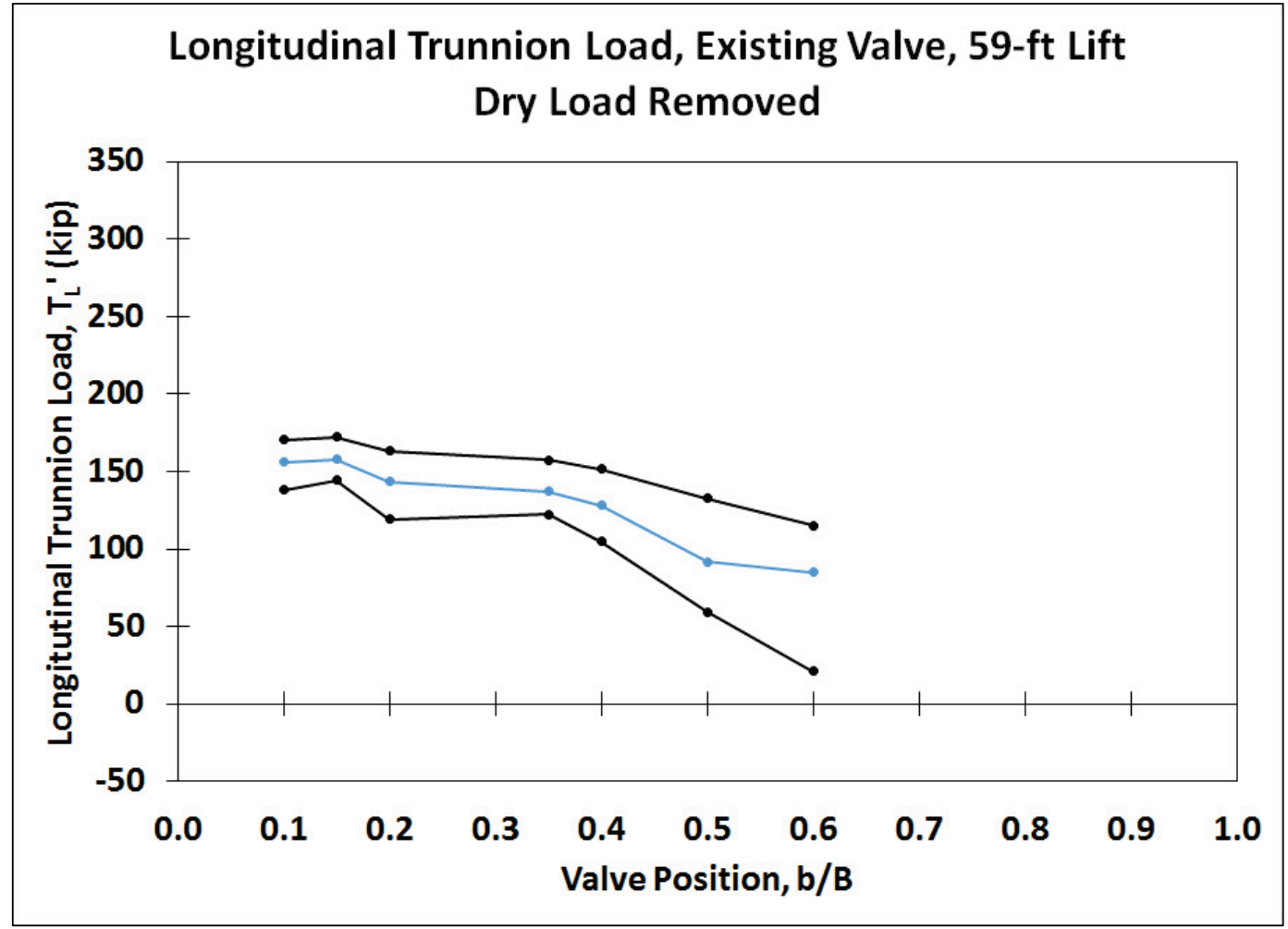

Figure 44. Existing valve resultant trunnion load $-51 \mathrm{ft} \mathrm{lift.}$

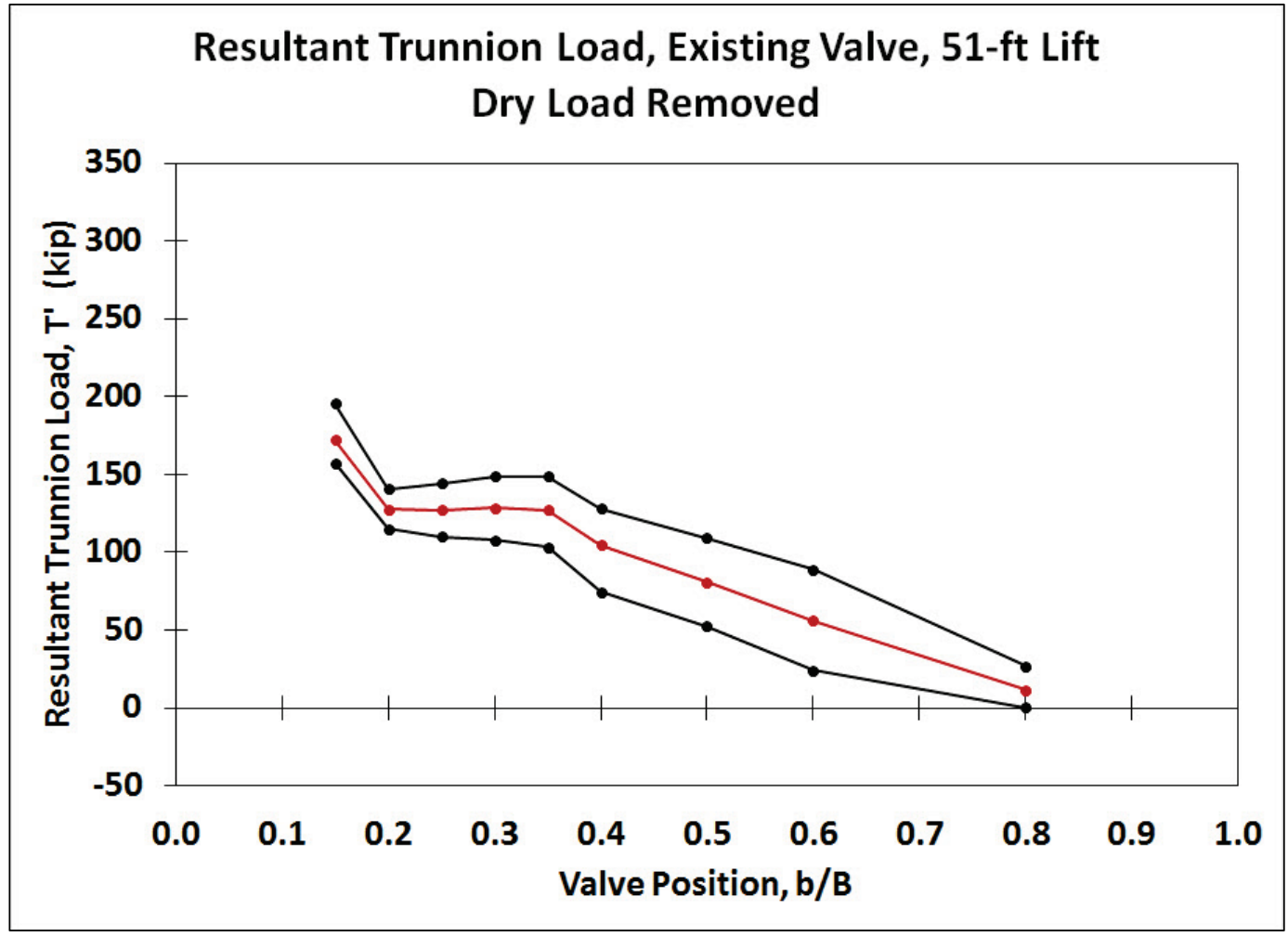


Figure 45. Existing valve resultant trunnion load $-59 \mathrm{ft}$ lift.

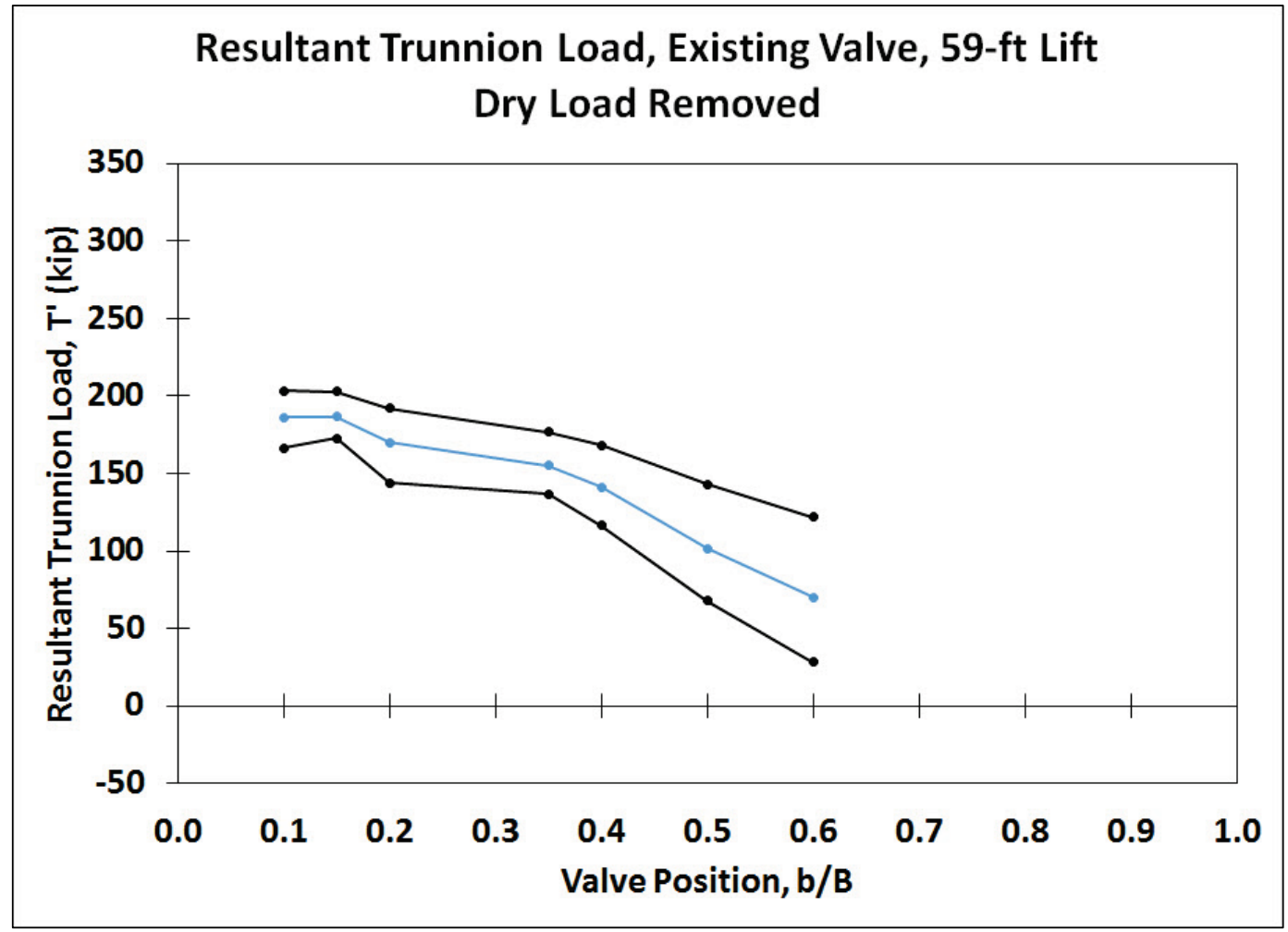

Figure 46. Existing valve vertical trunnion end load $-51 \mathrm{ft}$ lift.

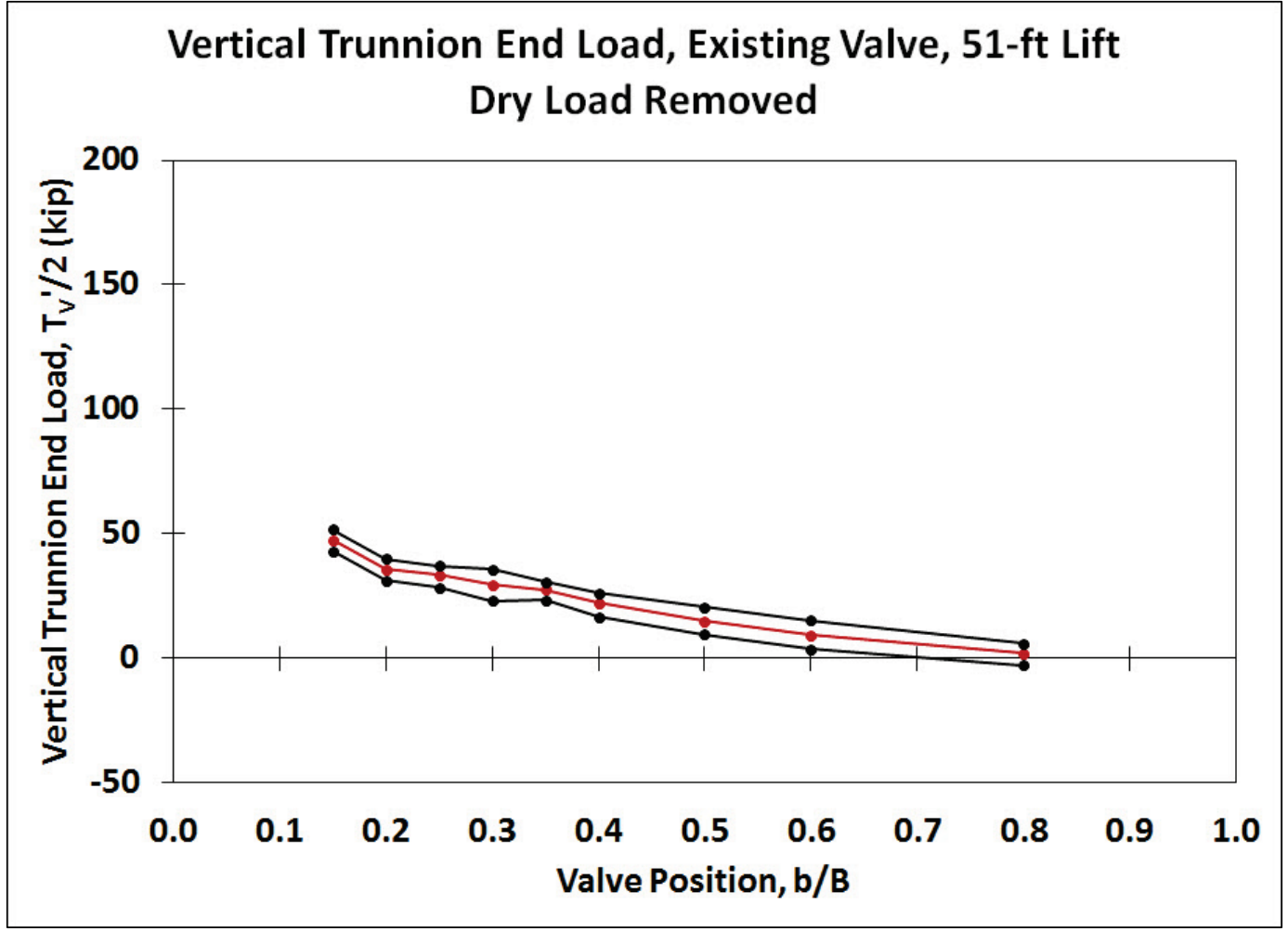


Figure 47. Existing valve vertical trunnion end load $-59 \mathrm{ft}$ lift.

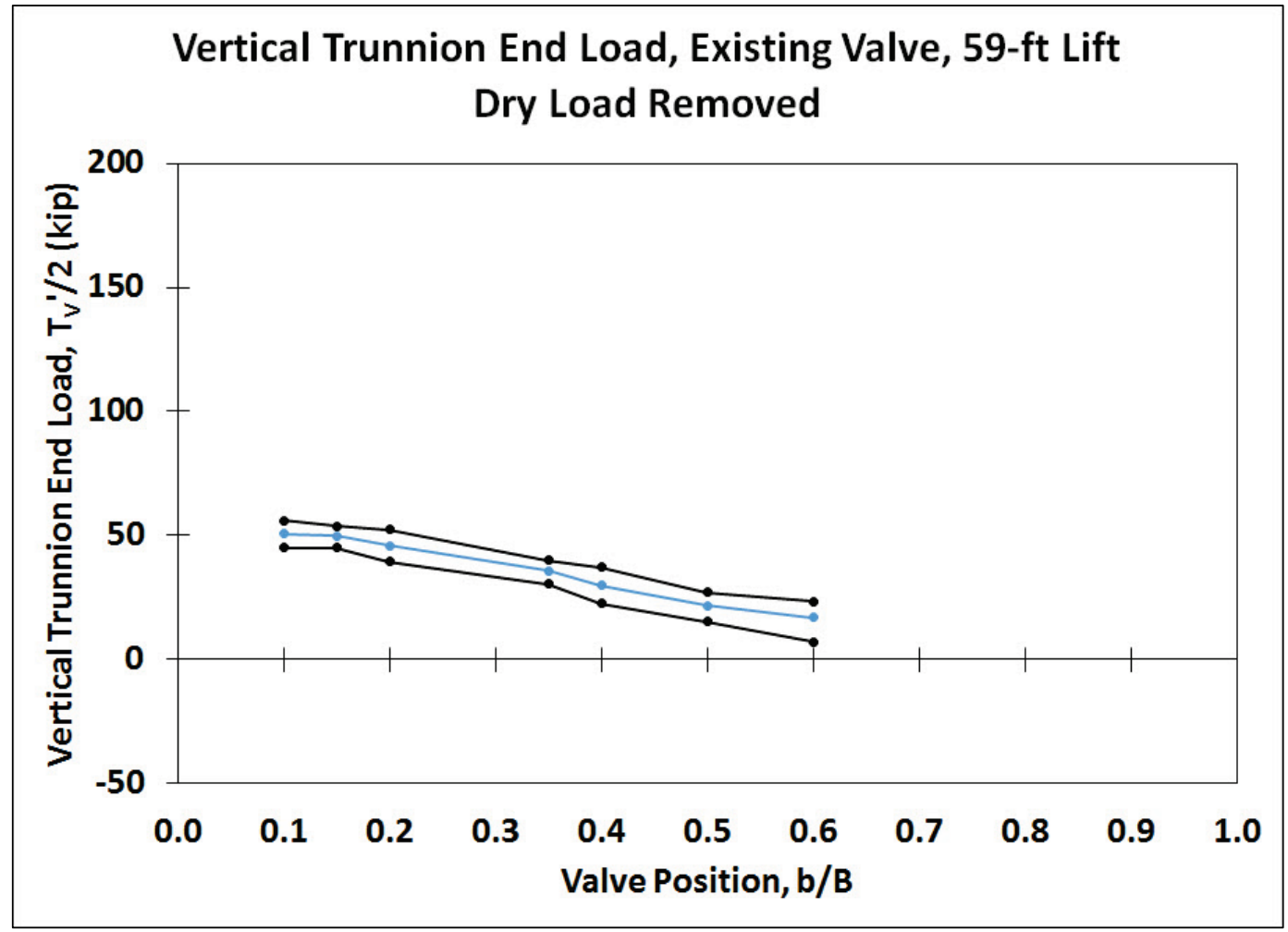

Figure 48. Existing valve longitudinal trunnion end load $-51 \mathrm{ft} \mathrm{lift}$.

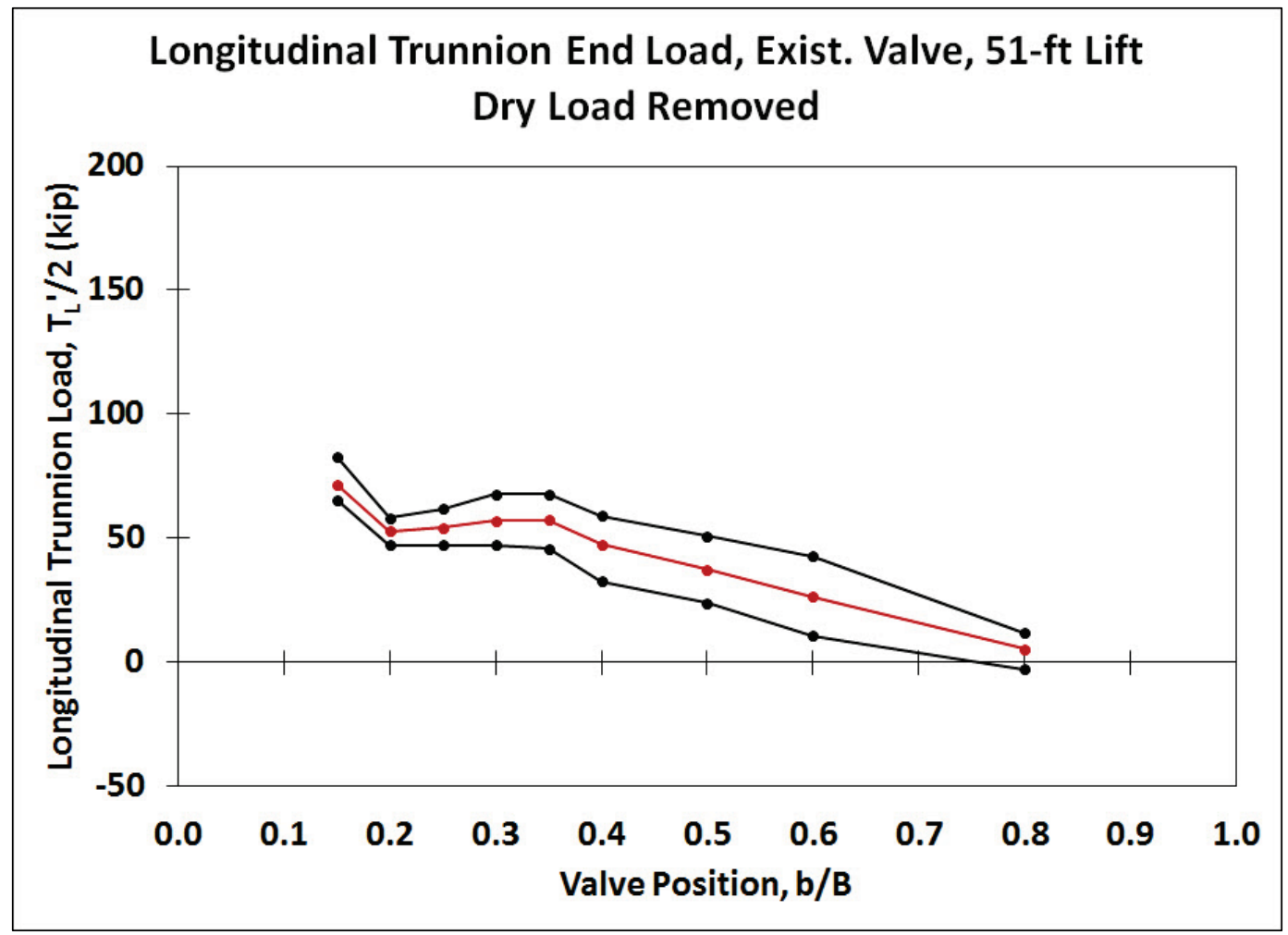


Figure 49. Existing valve longitudinal trunnion end load $-59 \mathrm{ft}$ lift.

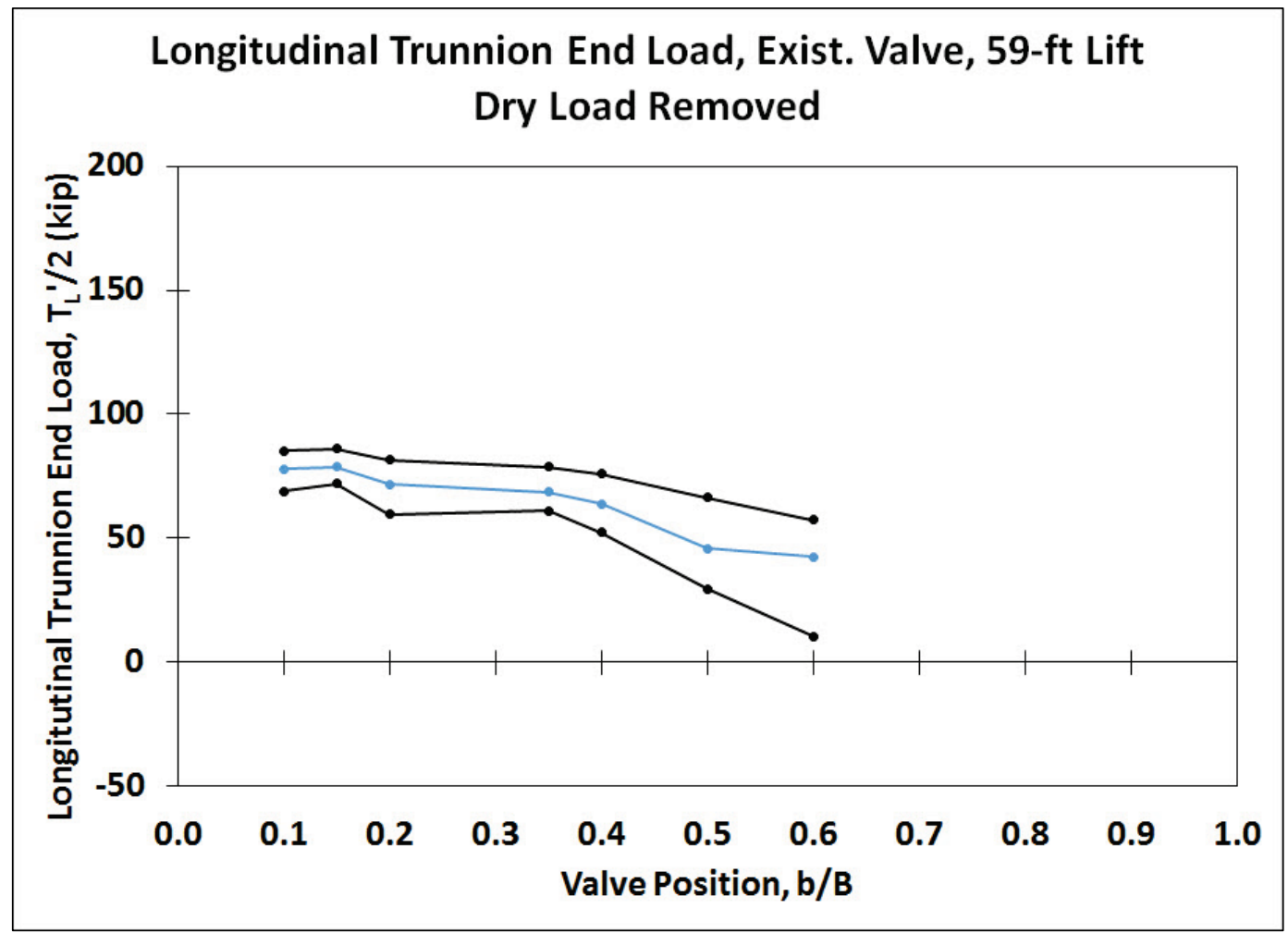

Figure 50. Existing valve resultant trunnion end load $-51 \mathrm{ft} \mathrm{lift.}$

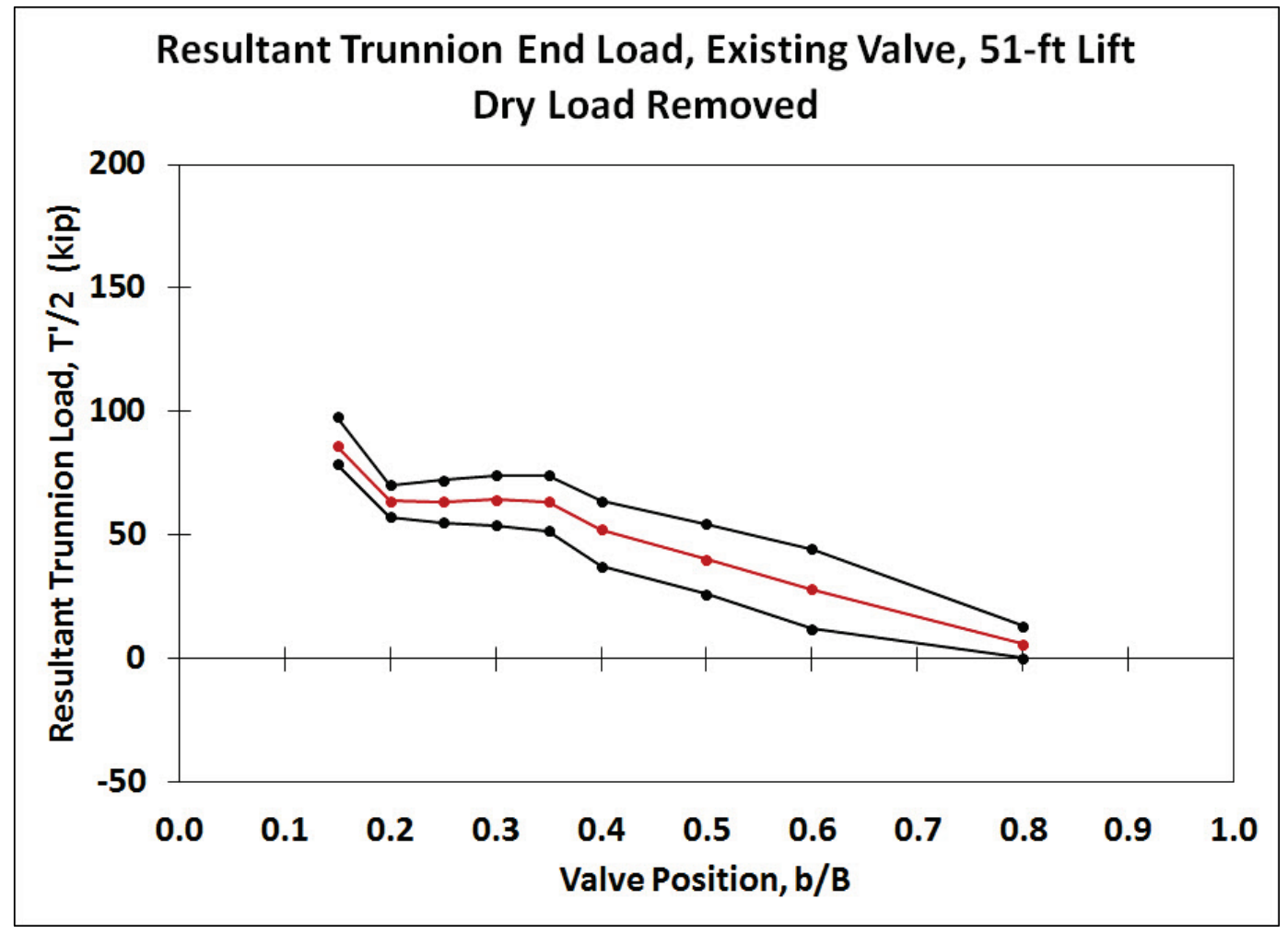


Figure 51. Existing valve resultant trunnion end load $-59 \mathrm{ft}$ lift.

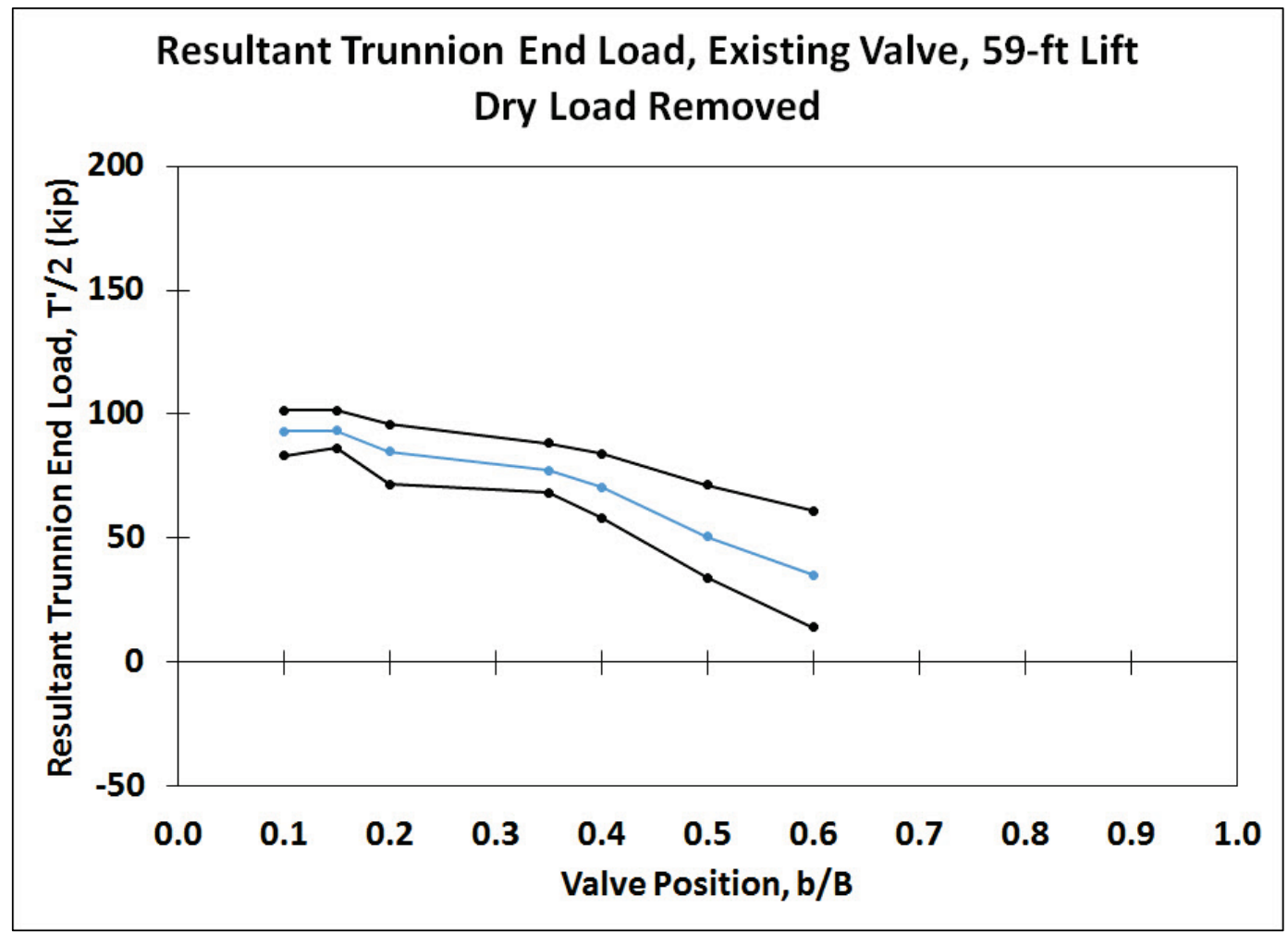

Figure 52. Existing valve vertical hydraulic load $-51 \mathrm{ft} \mathrm{lift.}$

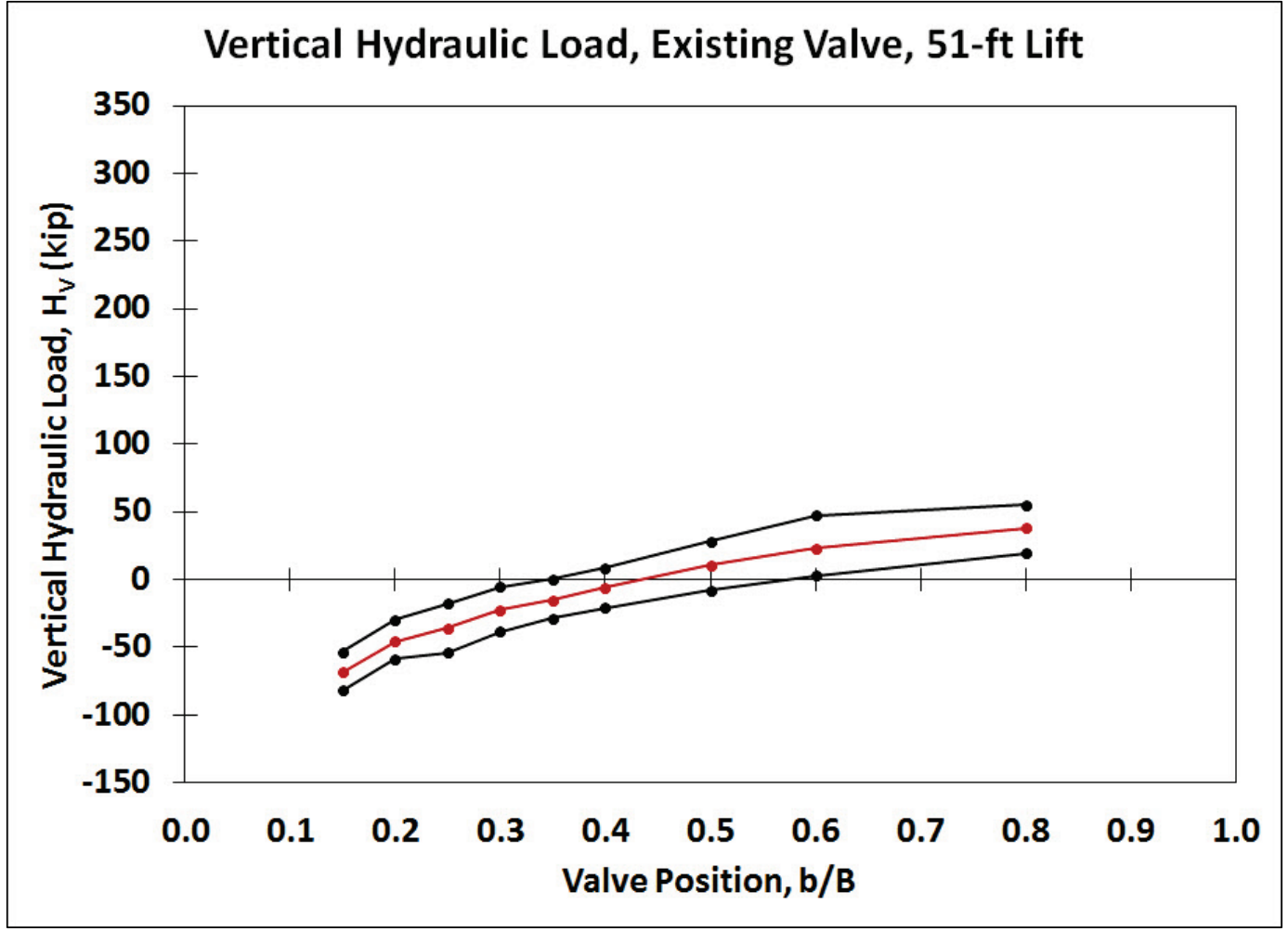


Figure 53. Existing valve vertical hydraulic load $-59 \mathrm{ft}$ lift.

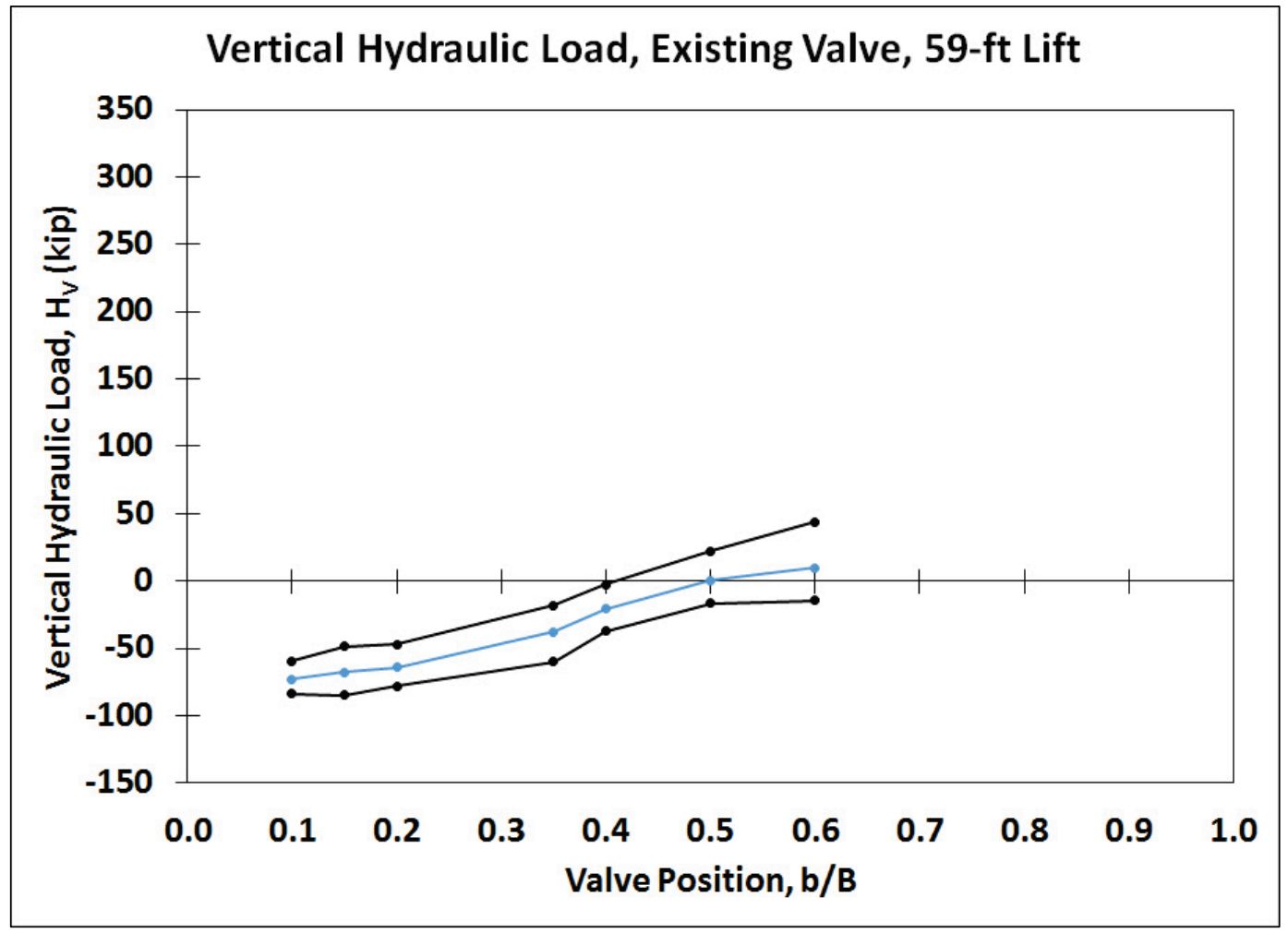

Figure 54. Existing valve longitudinal hydraulic load $-51 \mathrm{ft} \mathrm{lift}$.

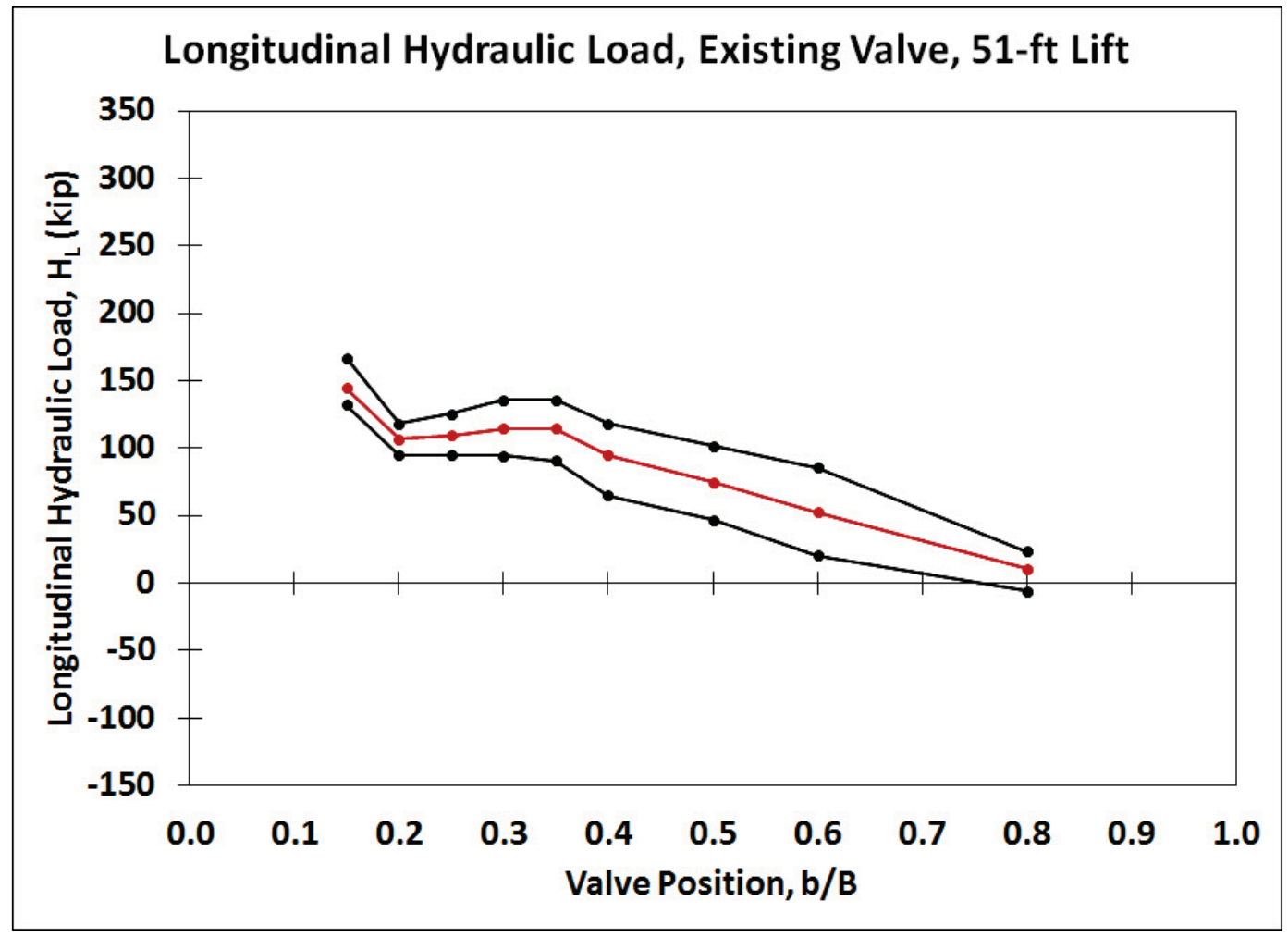


Figure 55. Existing valve longitudinal hydraulic load $-59 \mathrm{ft}$ lift.

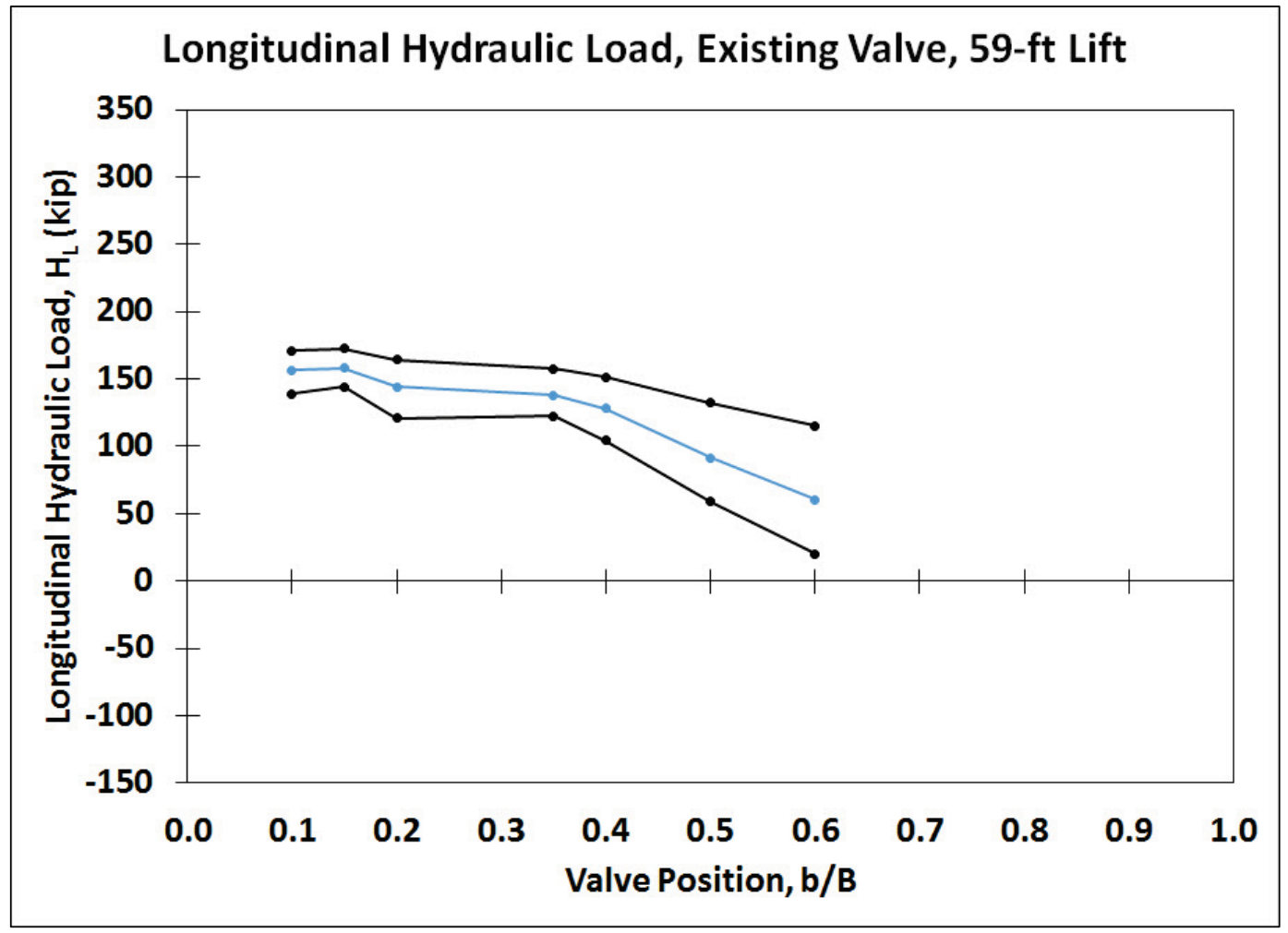

Figure 56. Existing valve resultant hydraulic load $-51 \mathrm{ft} \mathrm{lift.}$

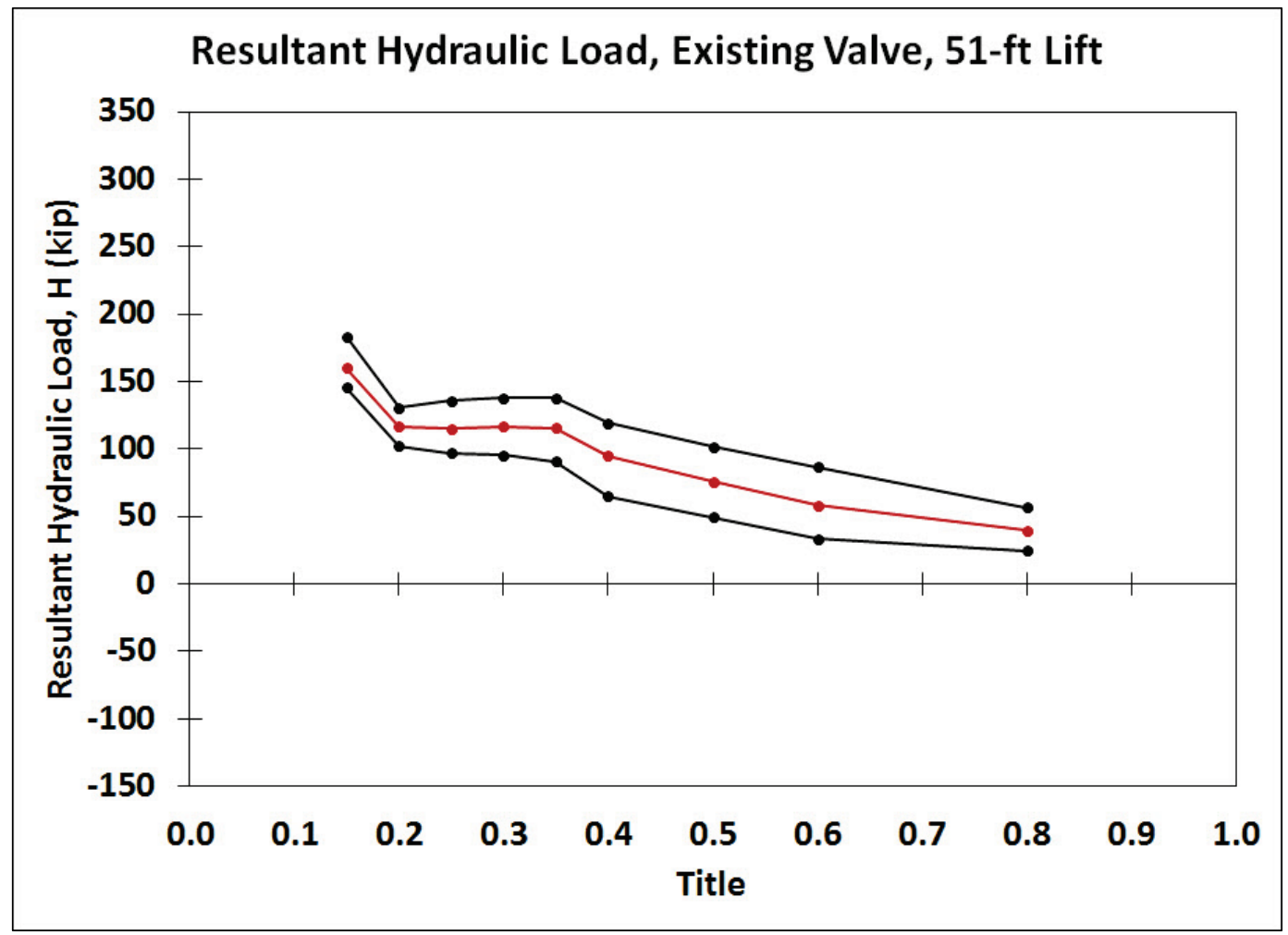


Figure 57. Existing valve resultant hydraulic load $-59 \mathrm{ft}$ lift.

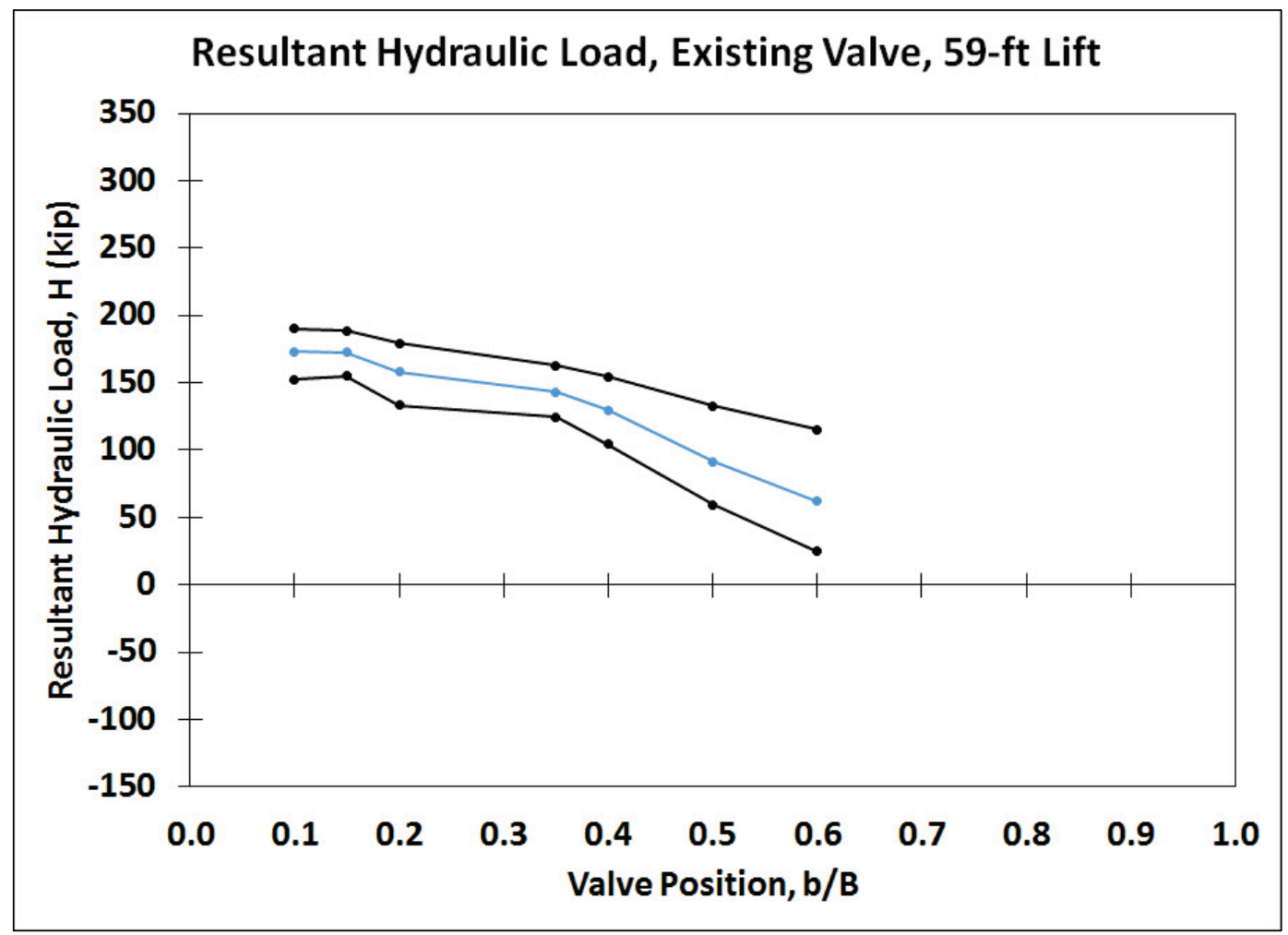

Figure 58. Pressure head distribution along culvert, existing valve, $51 \mathrm{ft}$ lift.

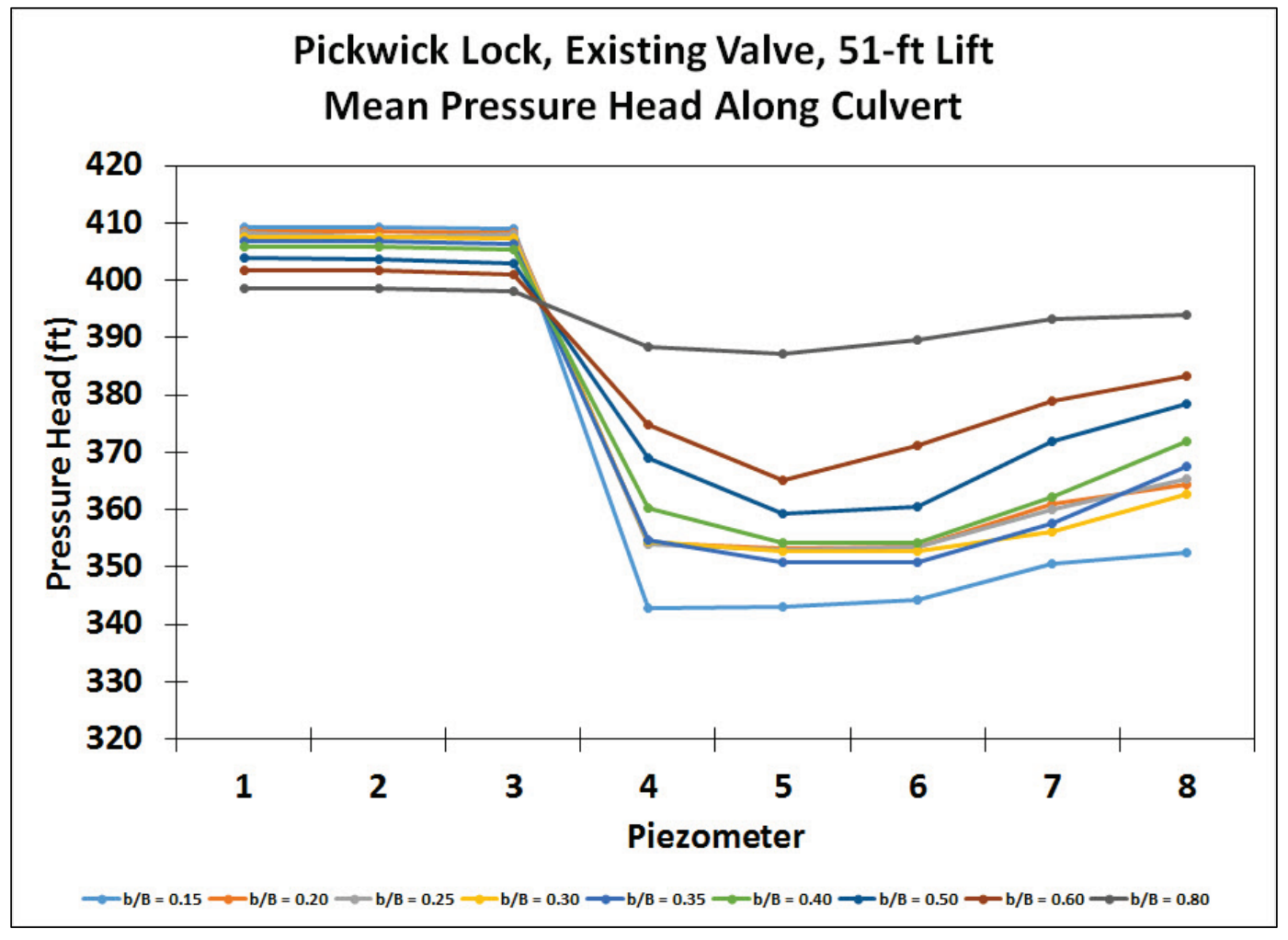


Figure 59. Pressure head distribution along culvert, existing valve, $59 \mathrm{ft}$ lift.

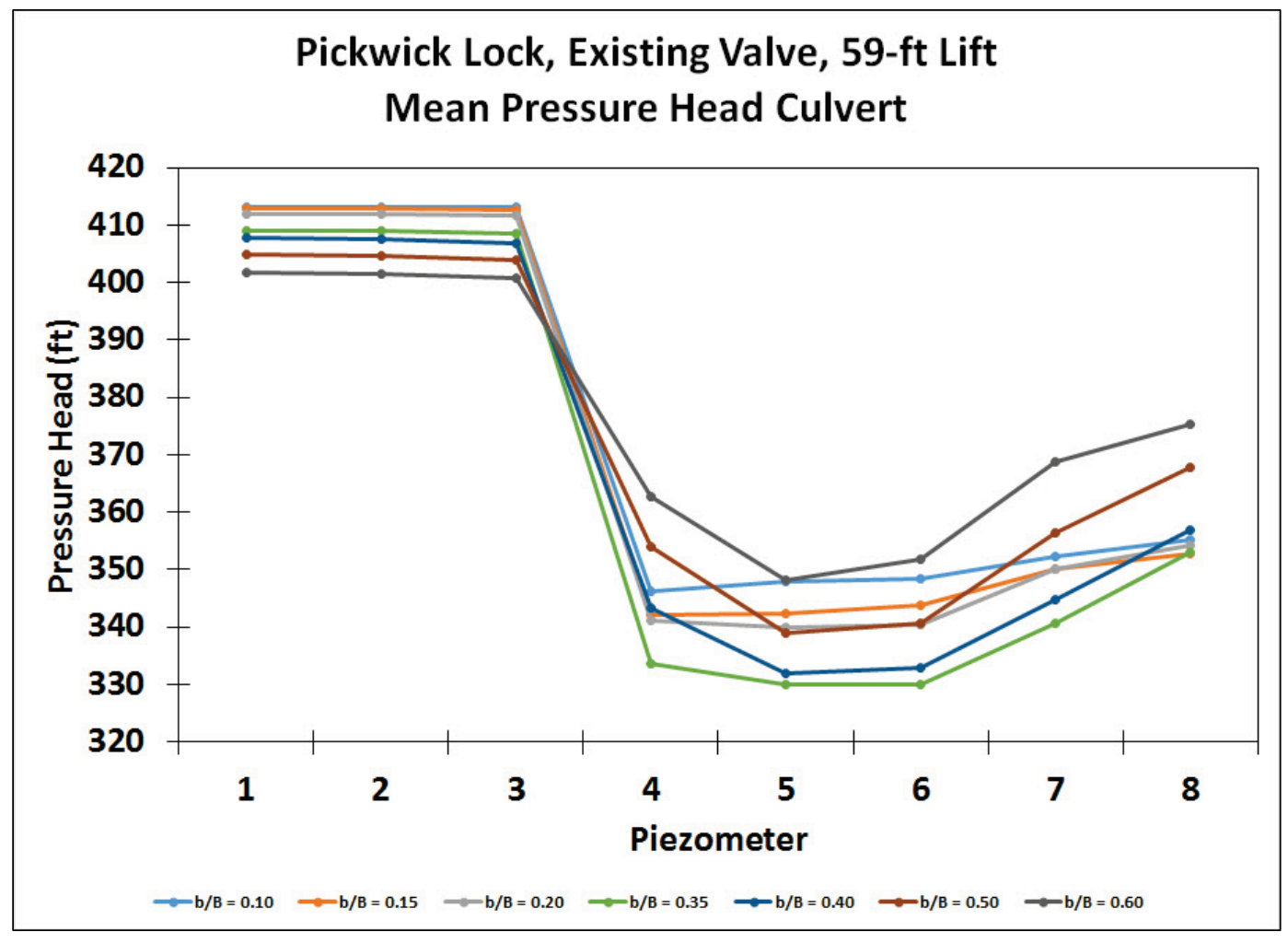




\section{Appendix B: Modified Valve Load Result Plots}

In this appendix, a description of each valve and the results for each experiment with the modified Pickwick Lock culvert valve are presented (Figures 60-81). The results include measured and calculated quantities. The forces acting on the valve - hoist, trunnion, and hydraulic - are presented in a series of plots. The results for each lift are included in separate plots, and each plot includes the mean, maximum, and minimum value for each valve position tested. Each set of results is obtained from three sets of valve experiments. The average, maximum, and minimum value (measured and calculated for each quantity) are recorded for each experiment. Then, the average, maximum, and minimum values of each quantity for each test (average of averages, maximum of maxima, minimum of minima) are calculated, and presented.

Figure 60. Modified valve hoist load $-51 \mathrm{ft} \mathrm{lift}$.

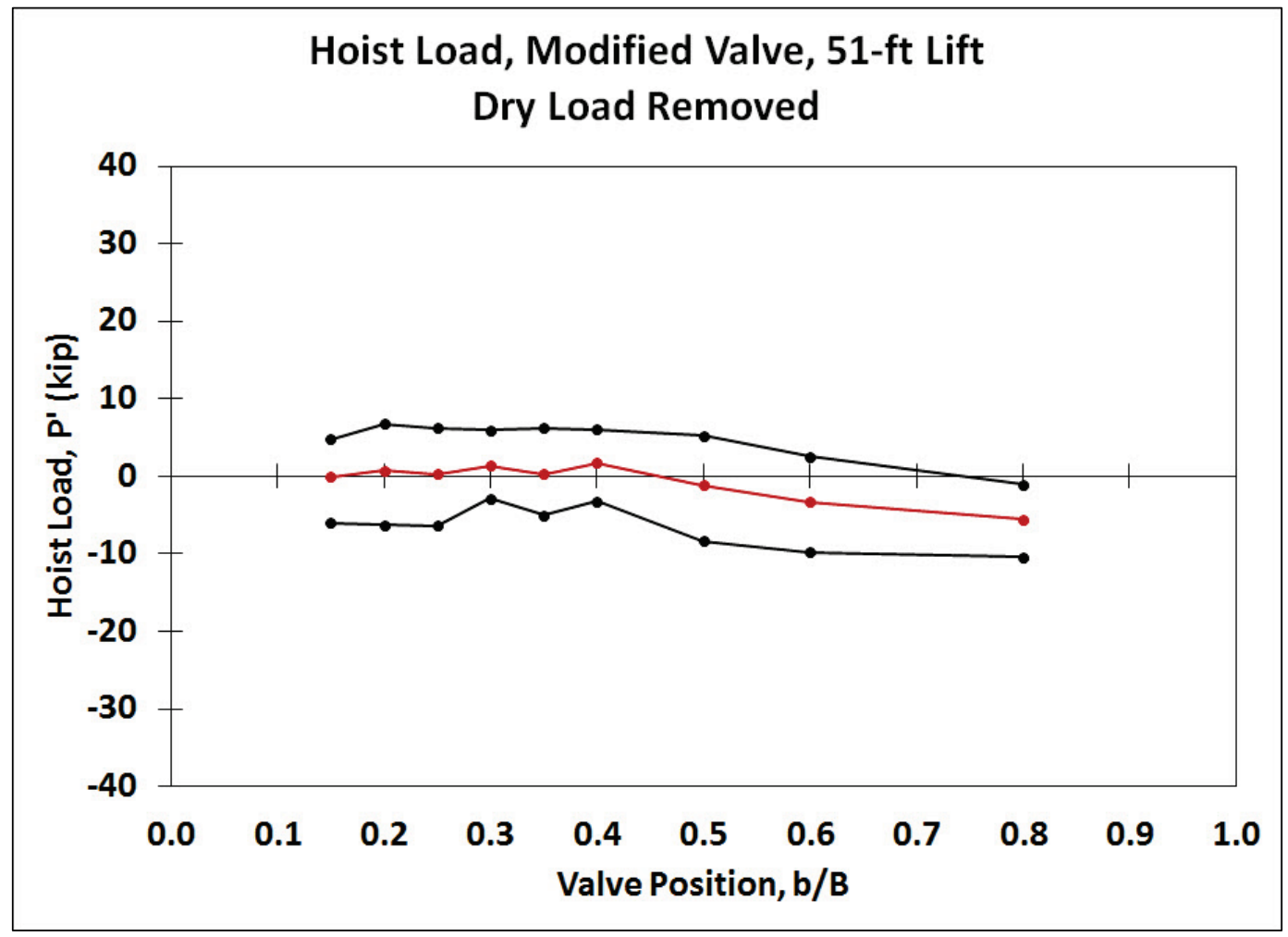


Figure 61. Modified valve hoist load $-59 \mathrm{ft}$ lift.

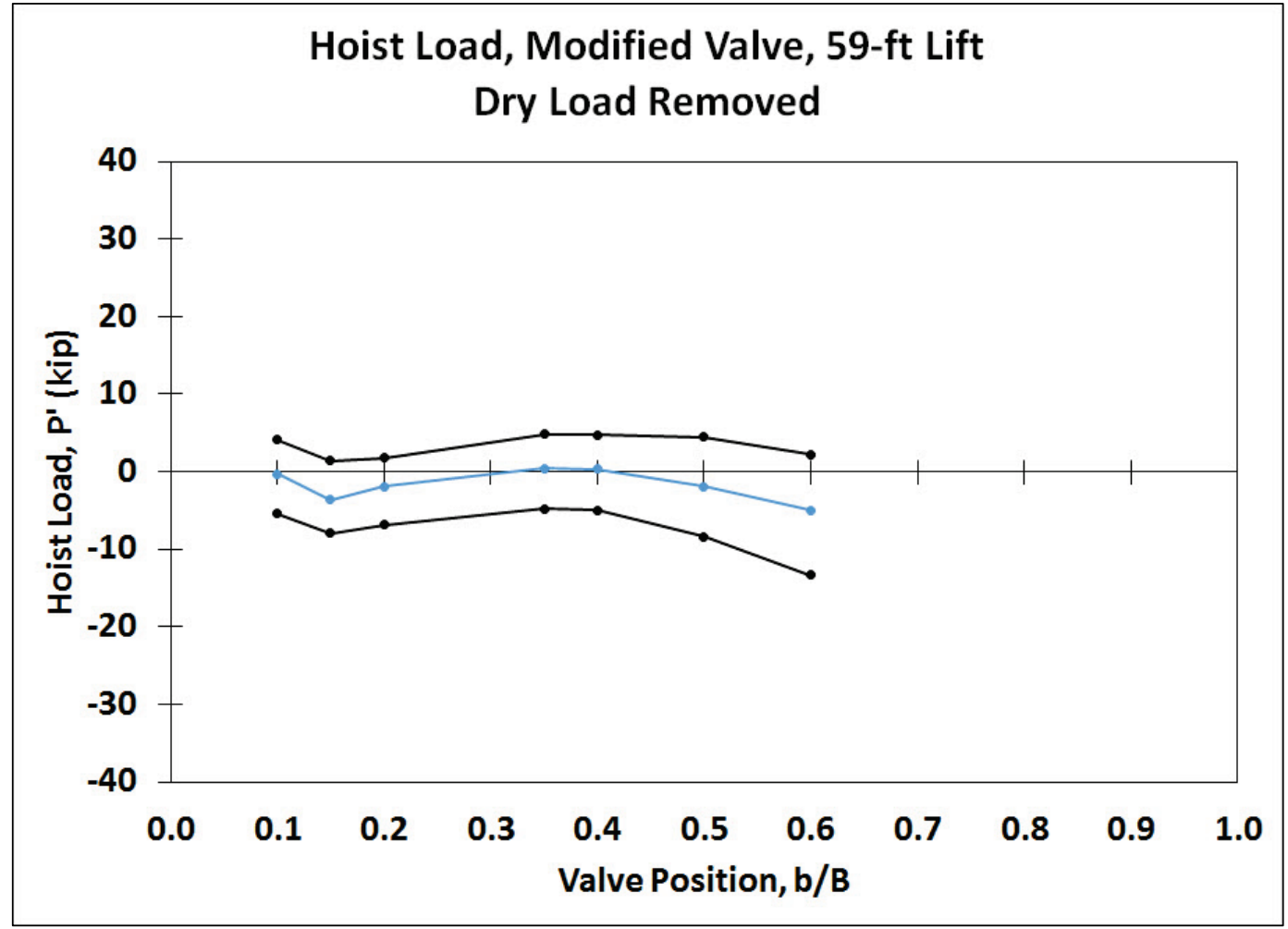

Figure 62. Modified valve vertical trunnion load $-51 \mathrm{ft} \mathrm{lift}$.

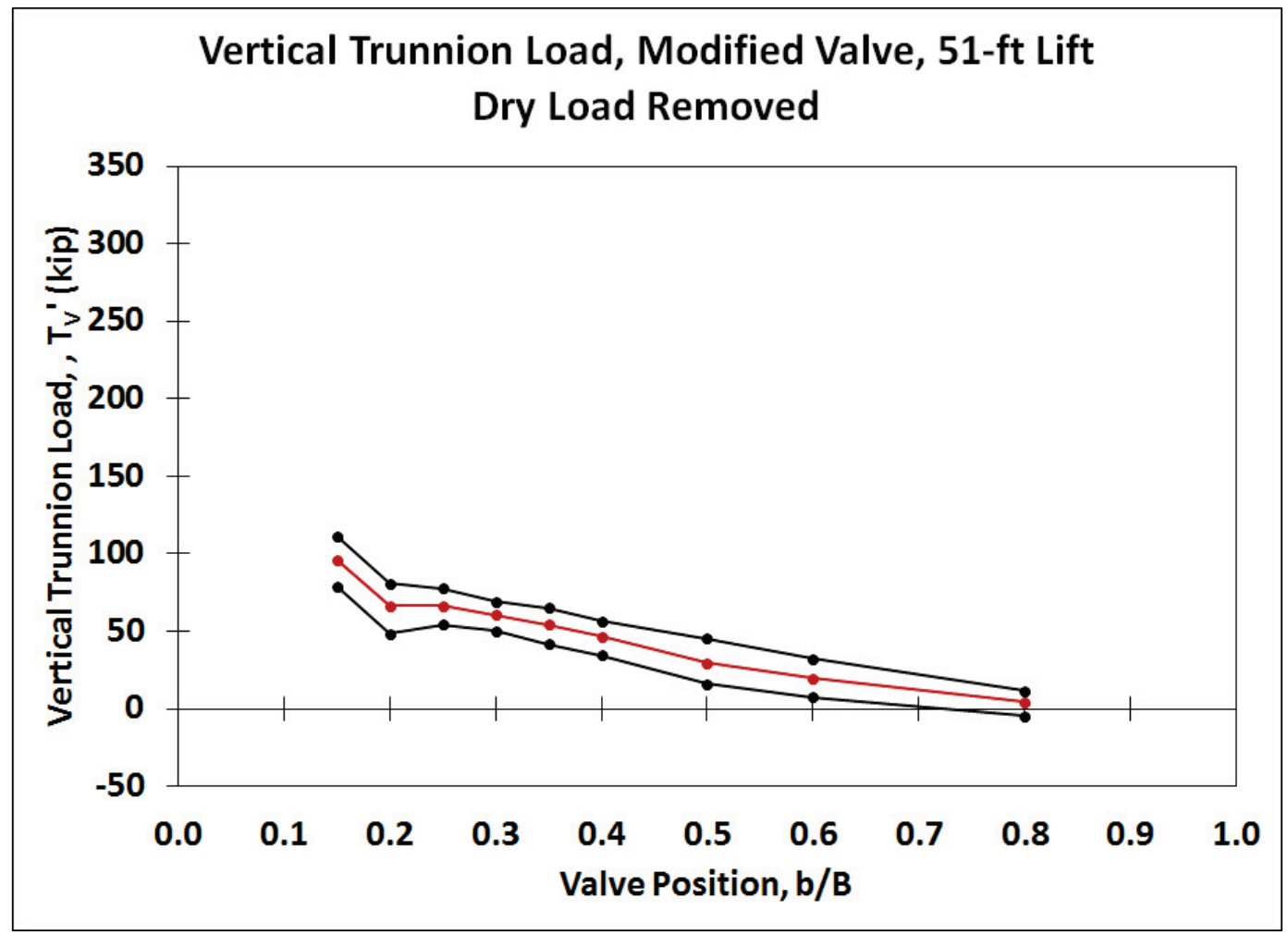


Figure 63. Modified valve vertical trunnion load $-59 \mathrm{ft} \mathrm{lift.}$

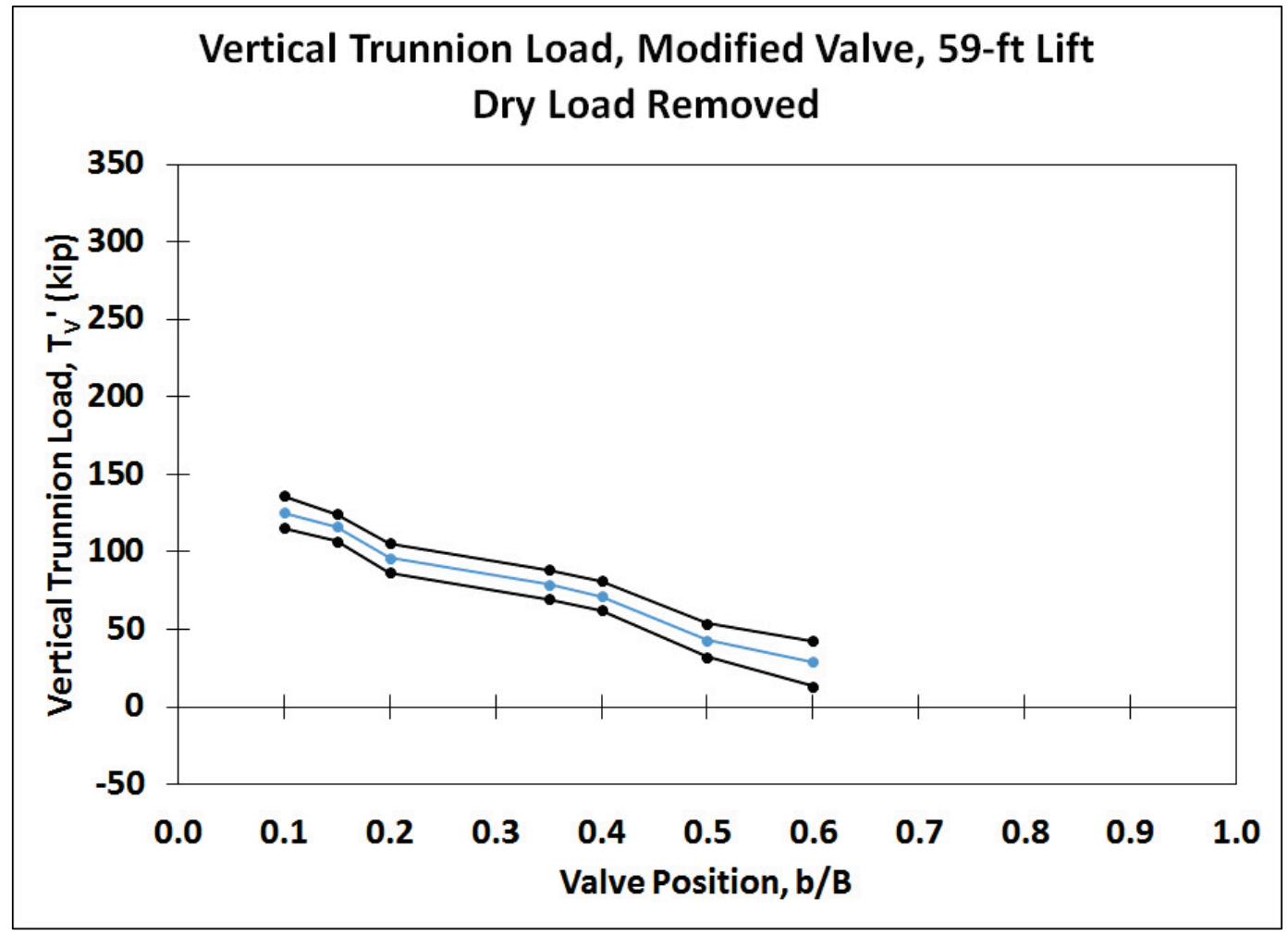

Figure 64. Modified valve longitudinal trunnion load $-51 \mathrm{ft}$ lift.

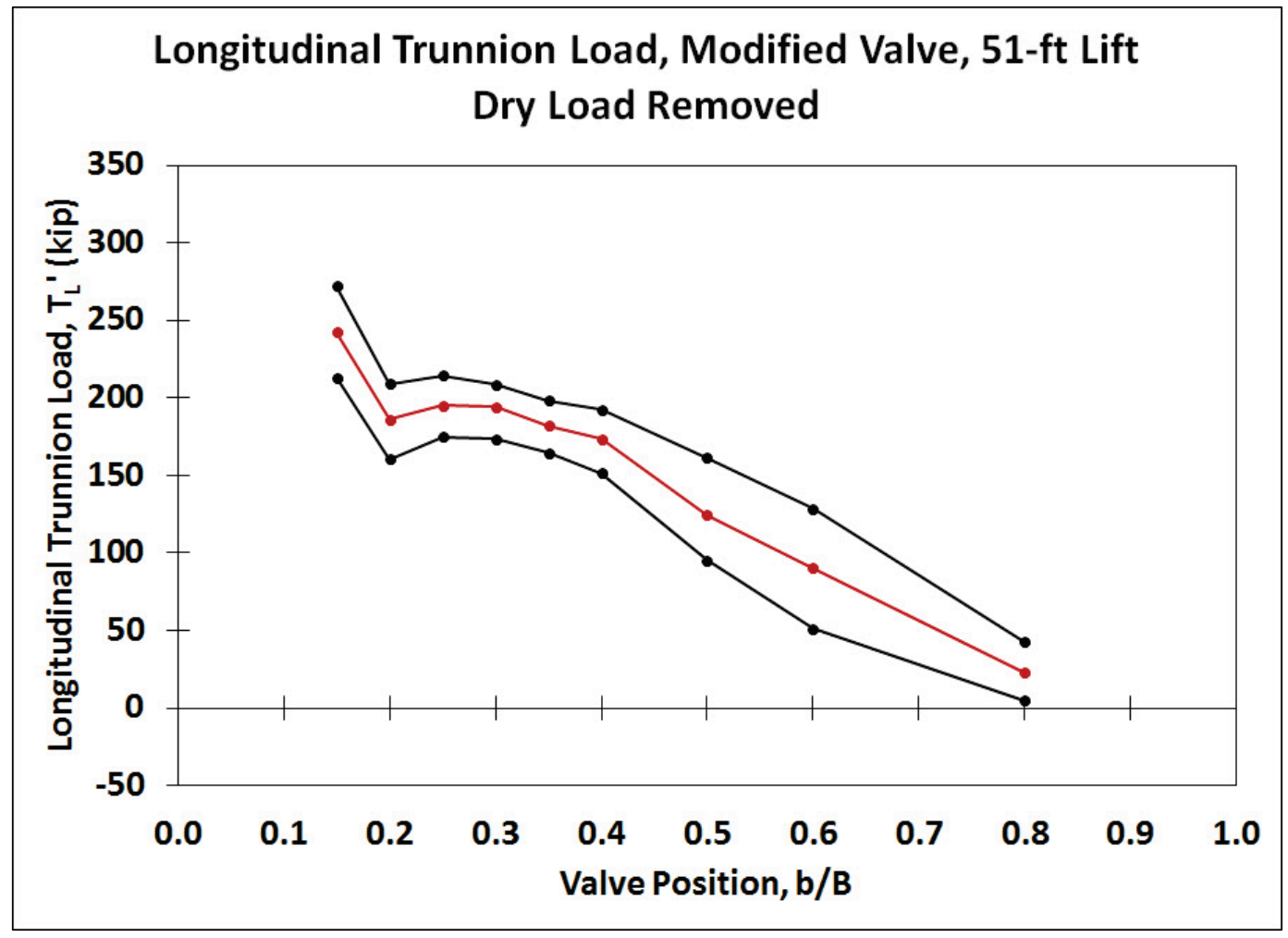


Figure 65. Modified valve longitudinal trunnion load $-59 \mathrm{ft}$ lift.

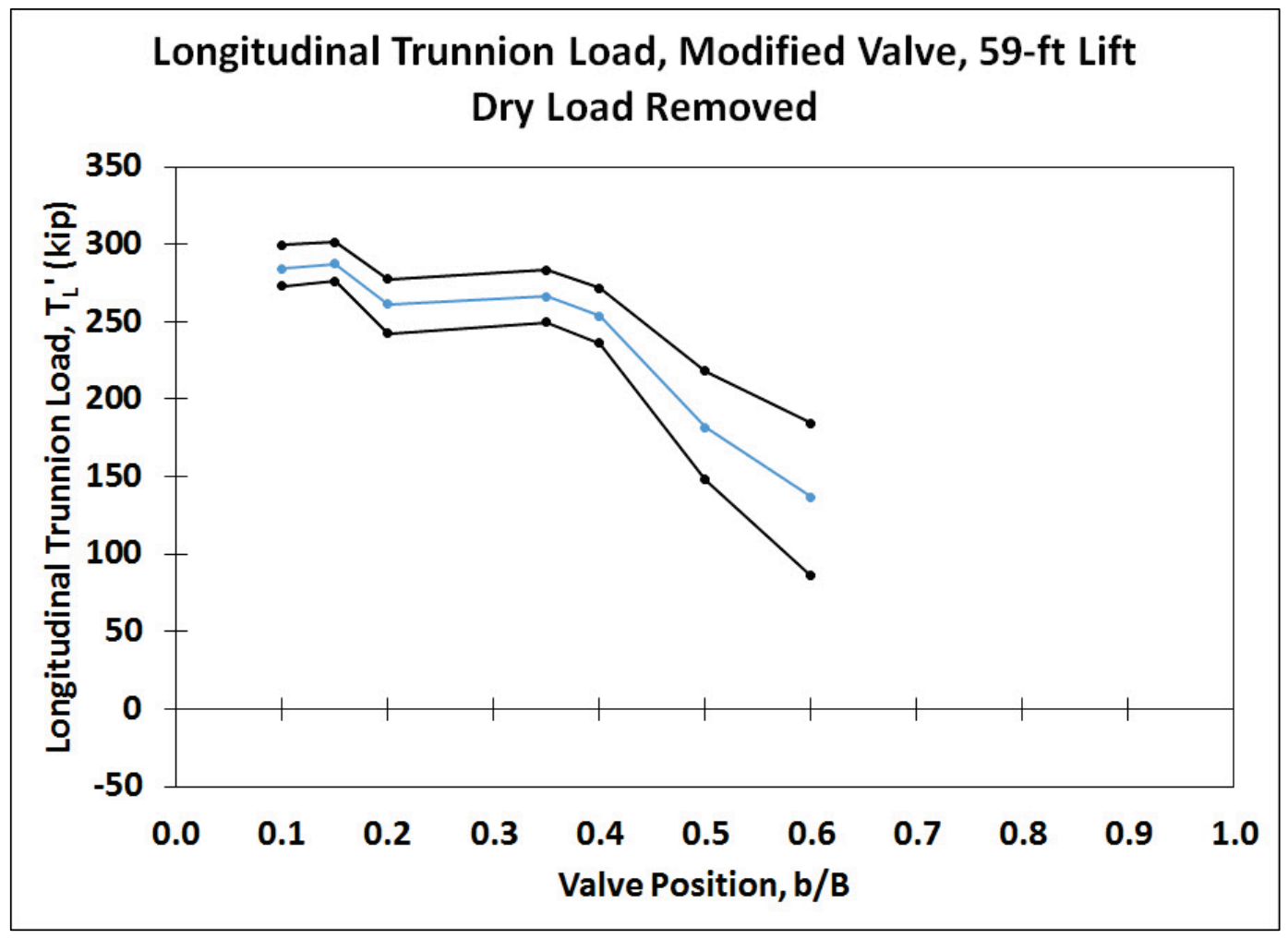

Figure 66. Modified valve resultant trunnion load $-51 \mathrm{ft}$ lift.

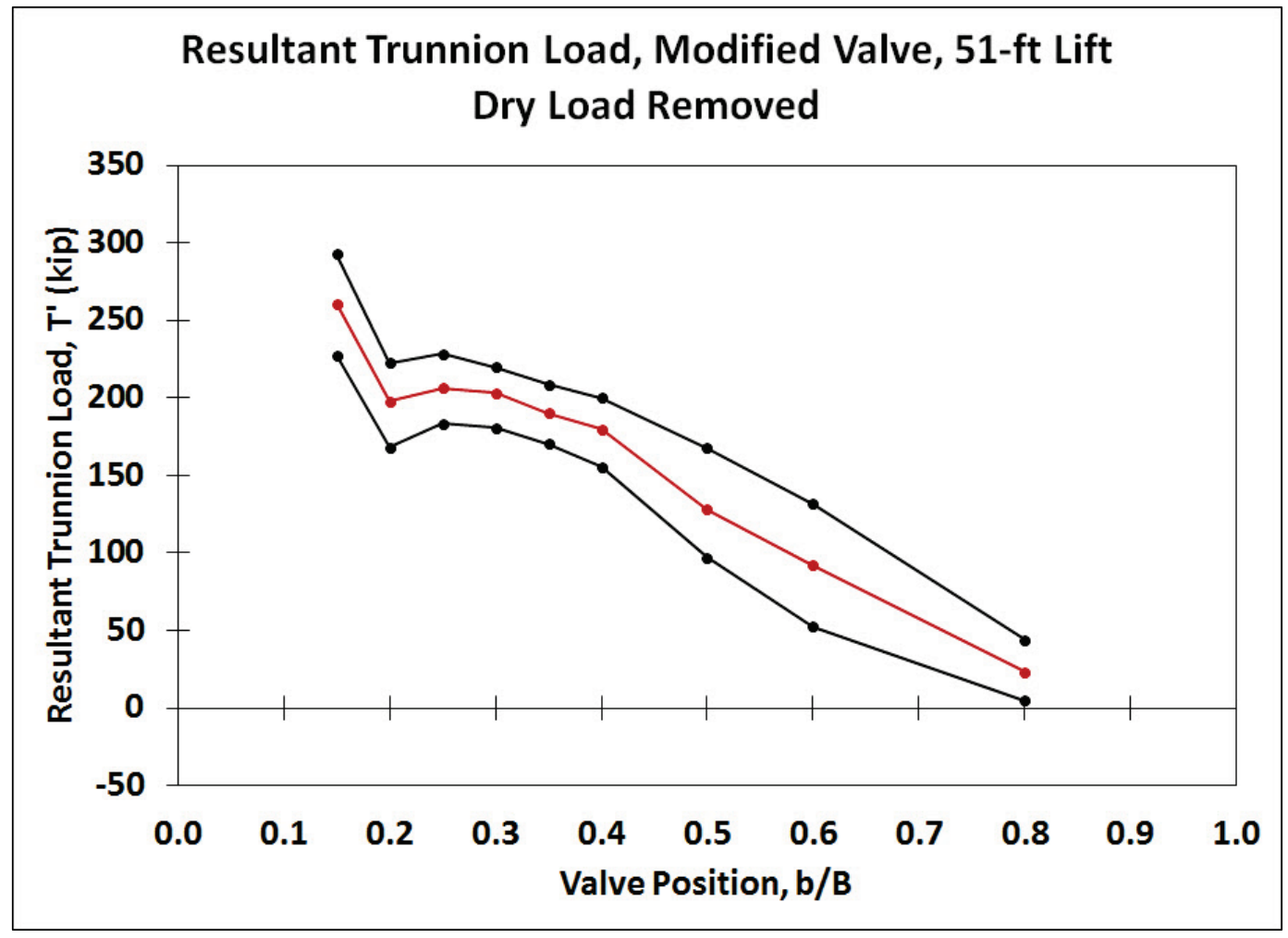


Figure 67. Modified valve resultant trunnion load $-59 \mathrm{ft}$ lift.

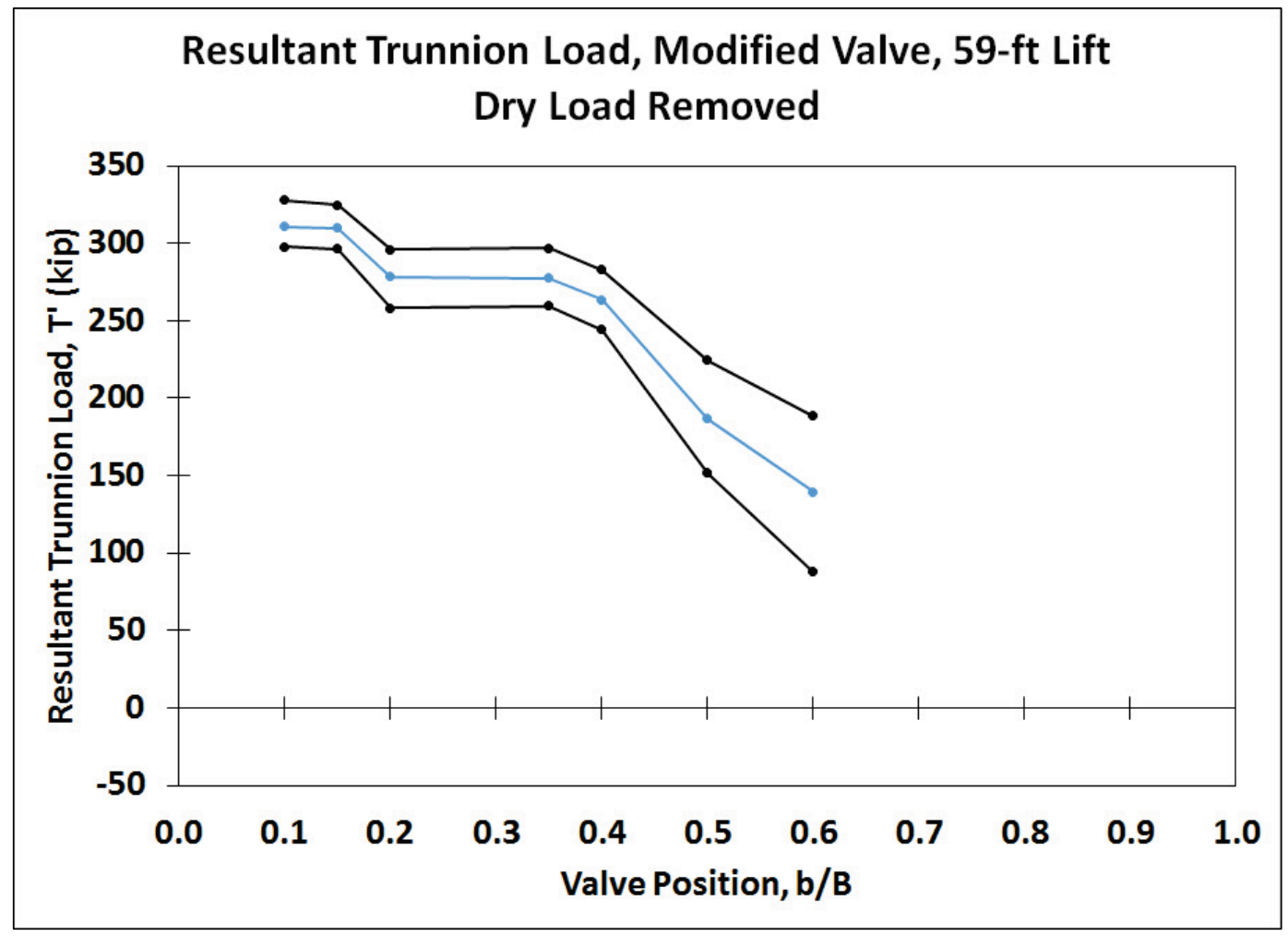

Figure 68. Modified valve vertical trunnion end load $-51 \mathrm{ft}$ lift.

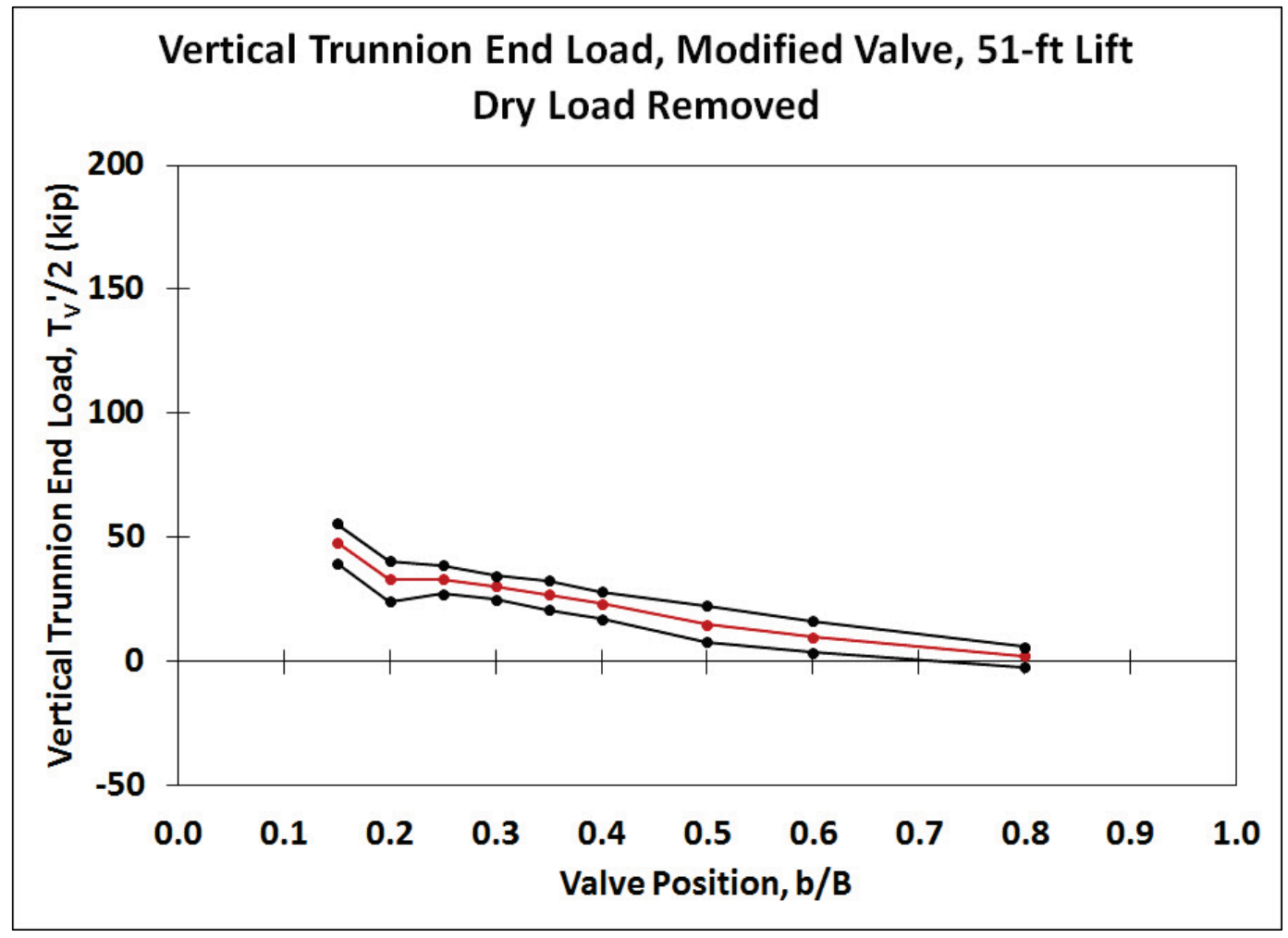


Figure 69. Modified valve vertical trunnion end load $-59 \mathrm{ft}$ lift.

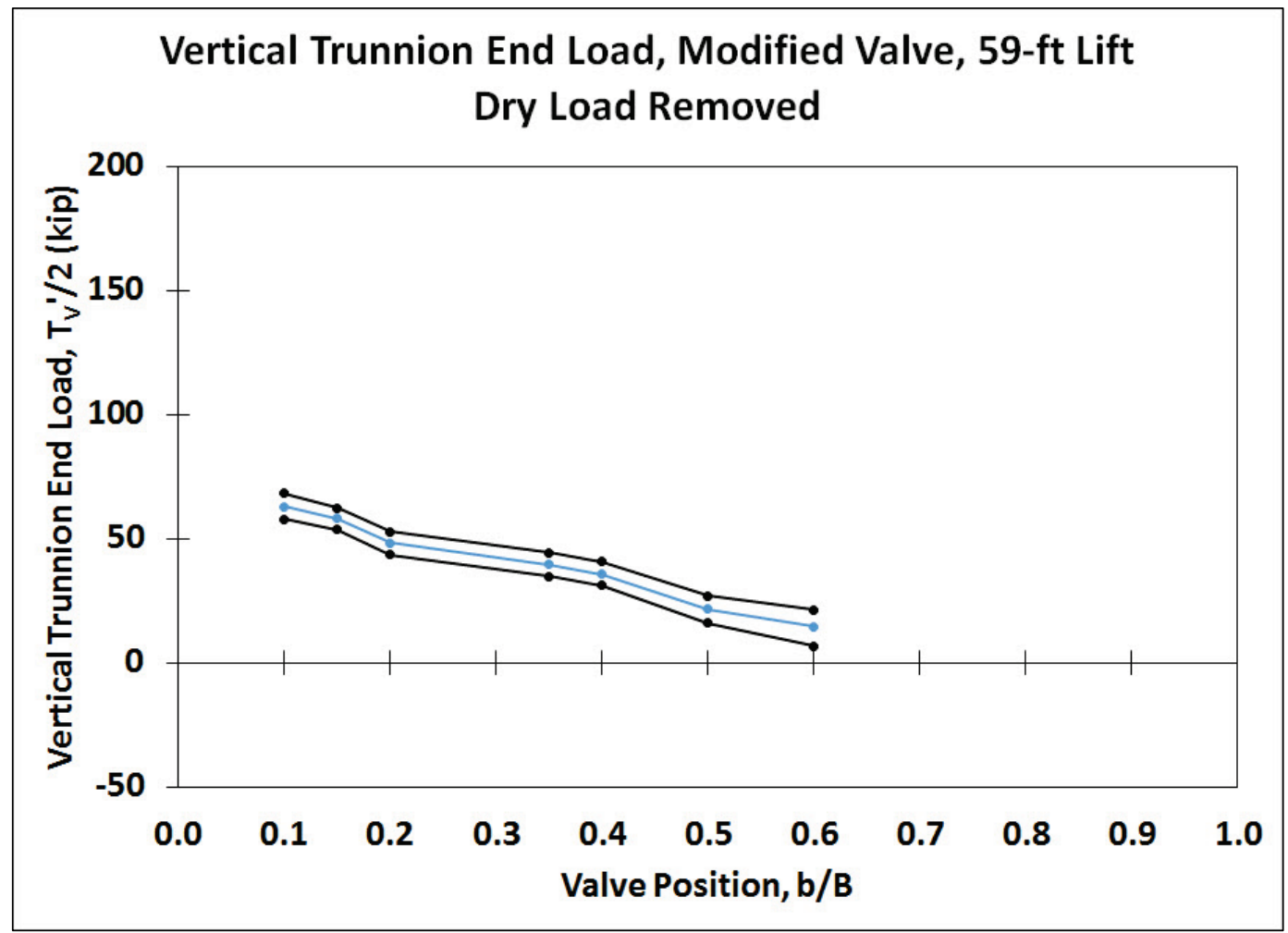

Figure 70. Modified valve longitudinal trunnion end load $-51 \mathrm{ft}$ lift.

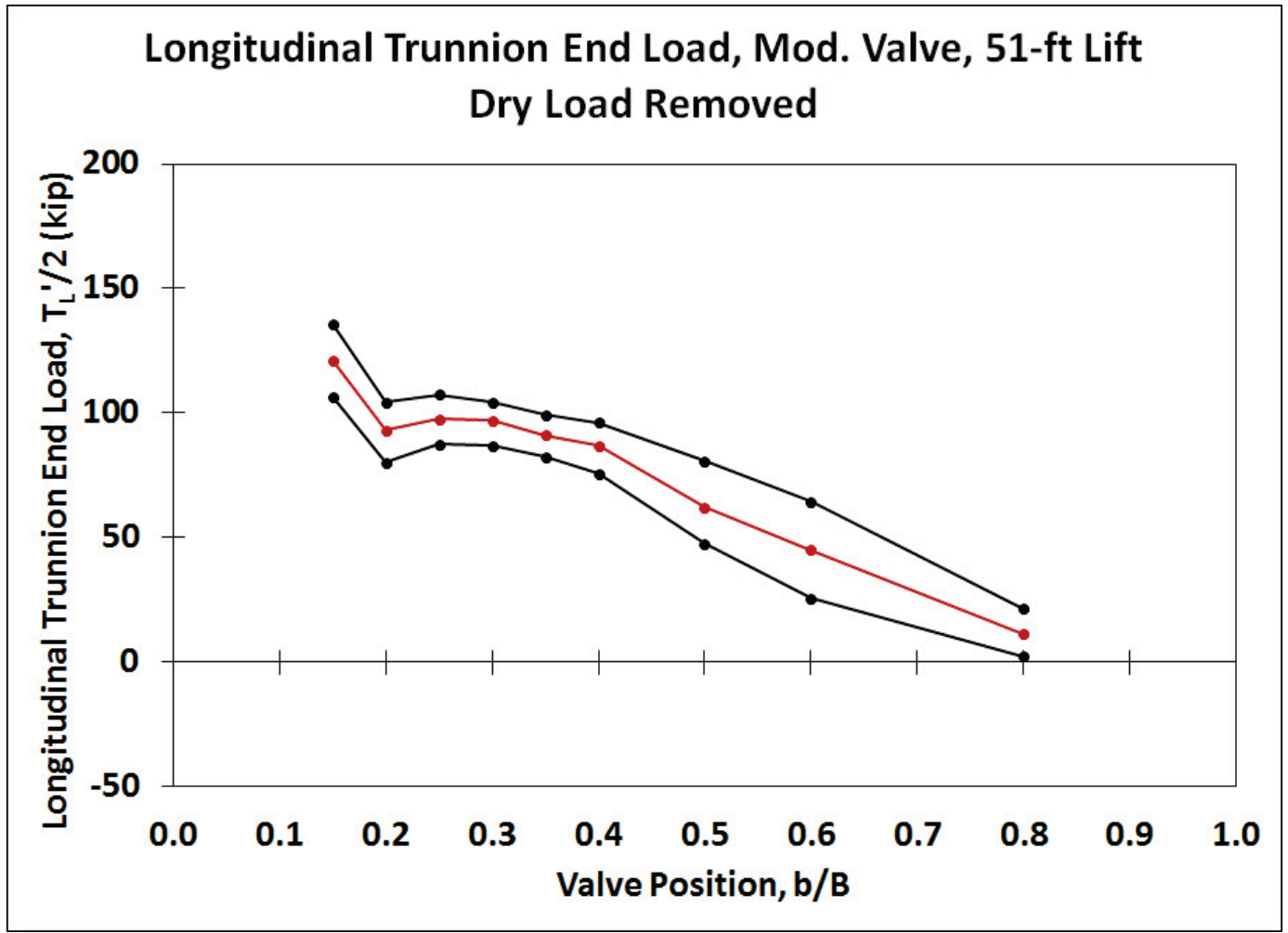


Figure 71 . Modified valve longitudinal trunnion end load $-59 \mathrm{ft} \mathrm{lift.}$

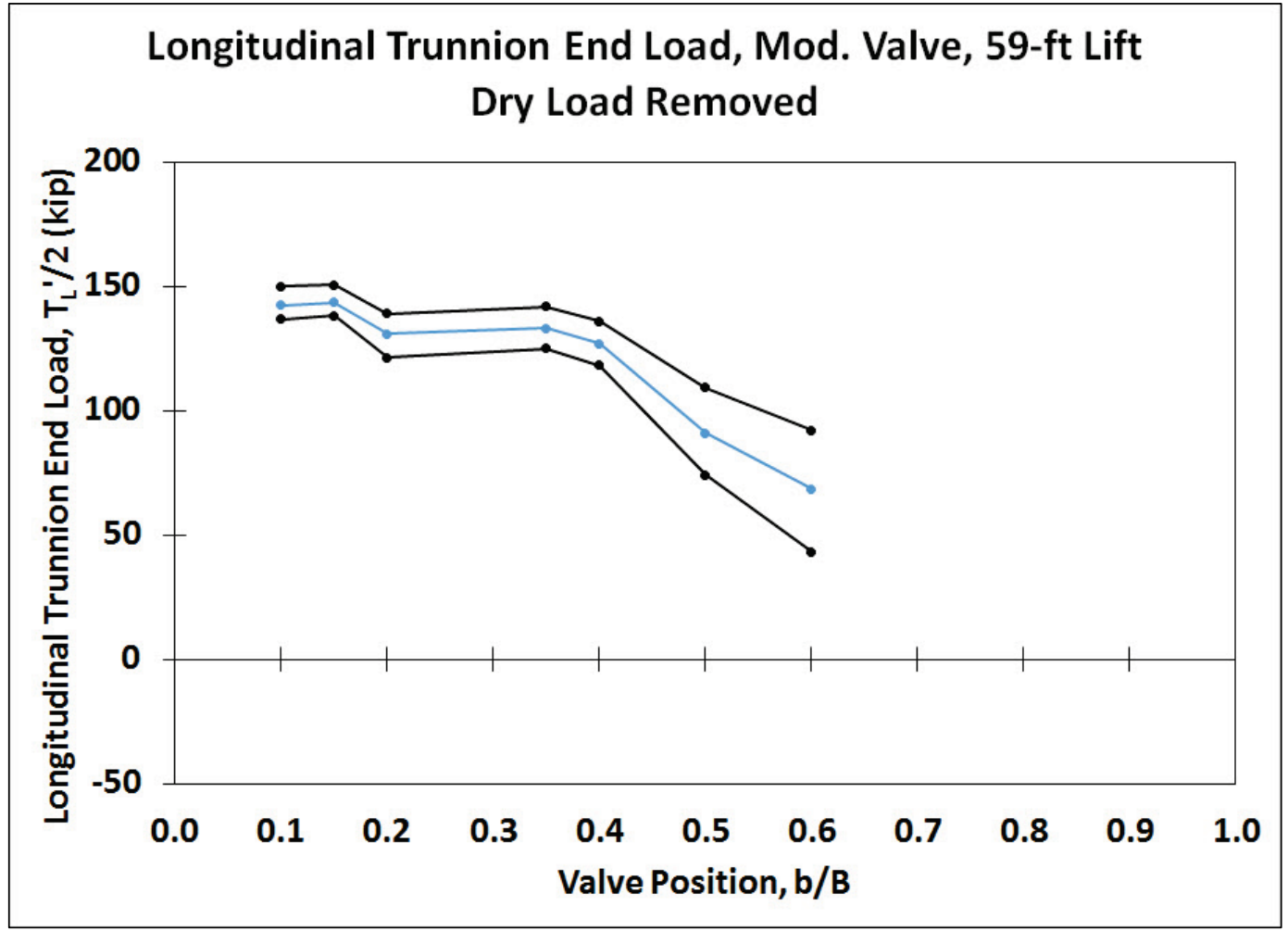

Figure 72. Modified valve resultant trunnion end load $-51 \mathrm{ft} \mathrm{lift.}$

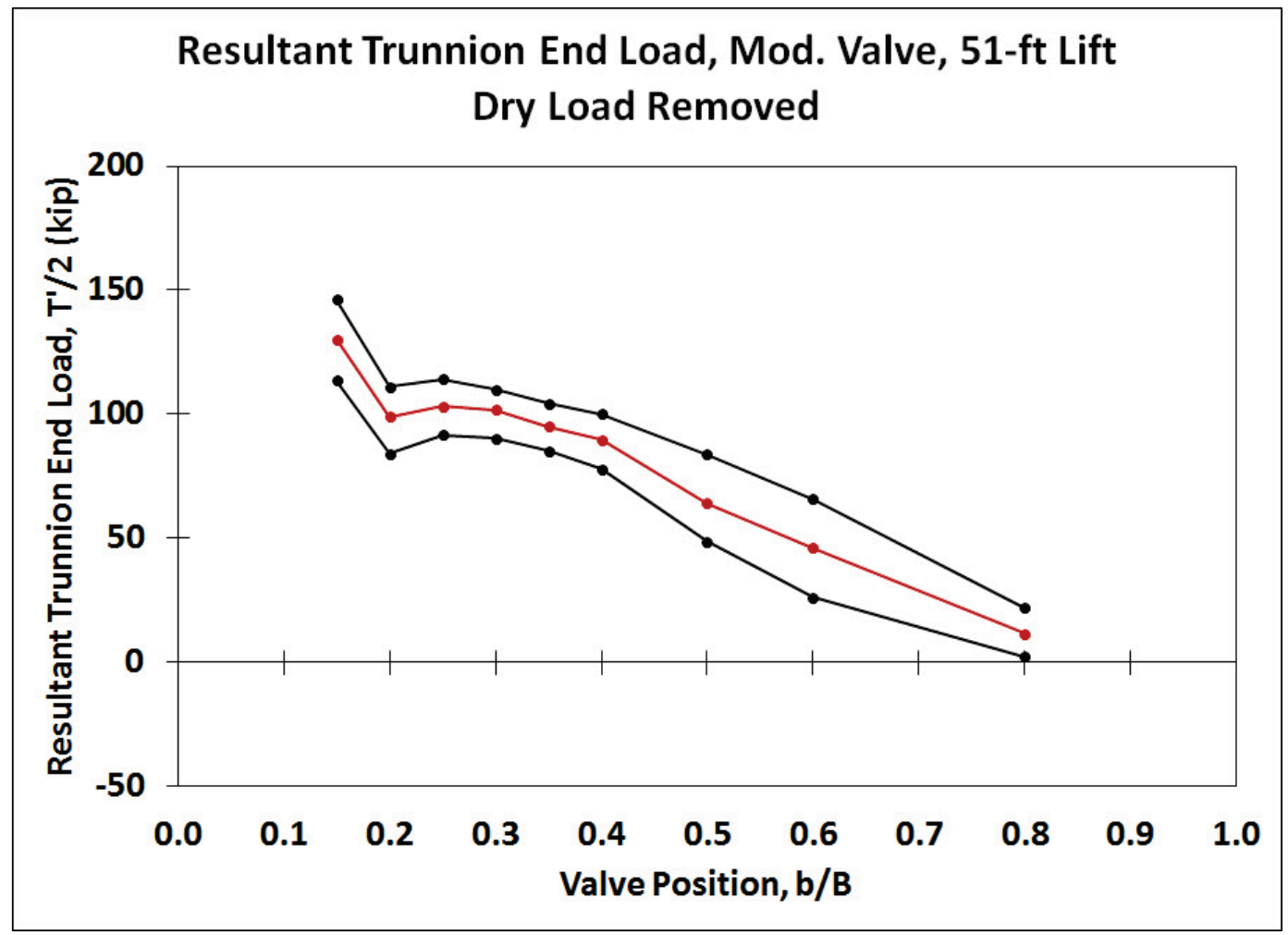


Figure 73. Modified valve resultant trunnion end load $-59 \mathrm{ft}$ lift.

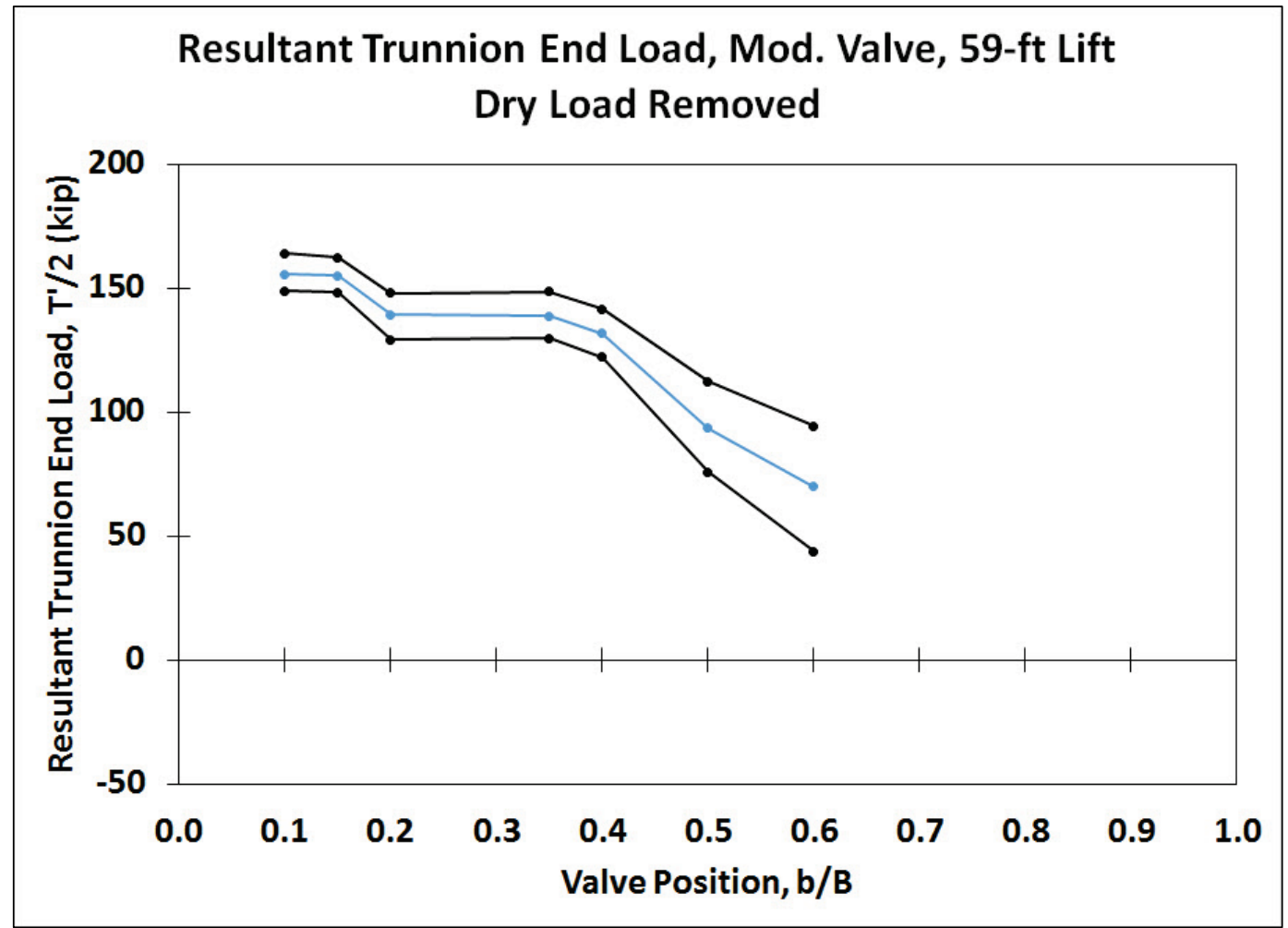

Figure 74. Modified valve vertical hydraulic load $-51 \mathrm{ft} \mathrm{lift.}$

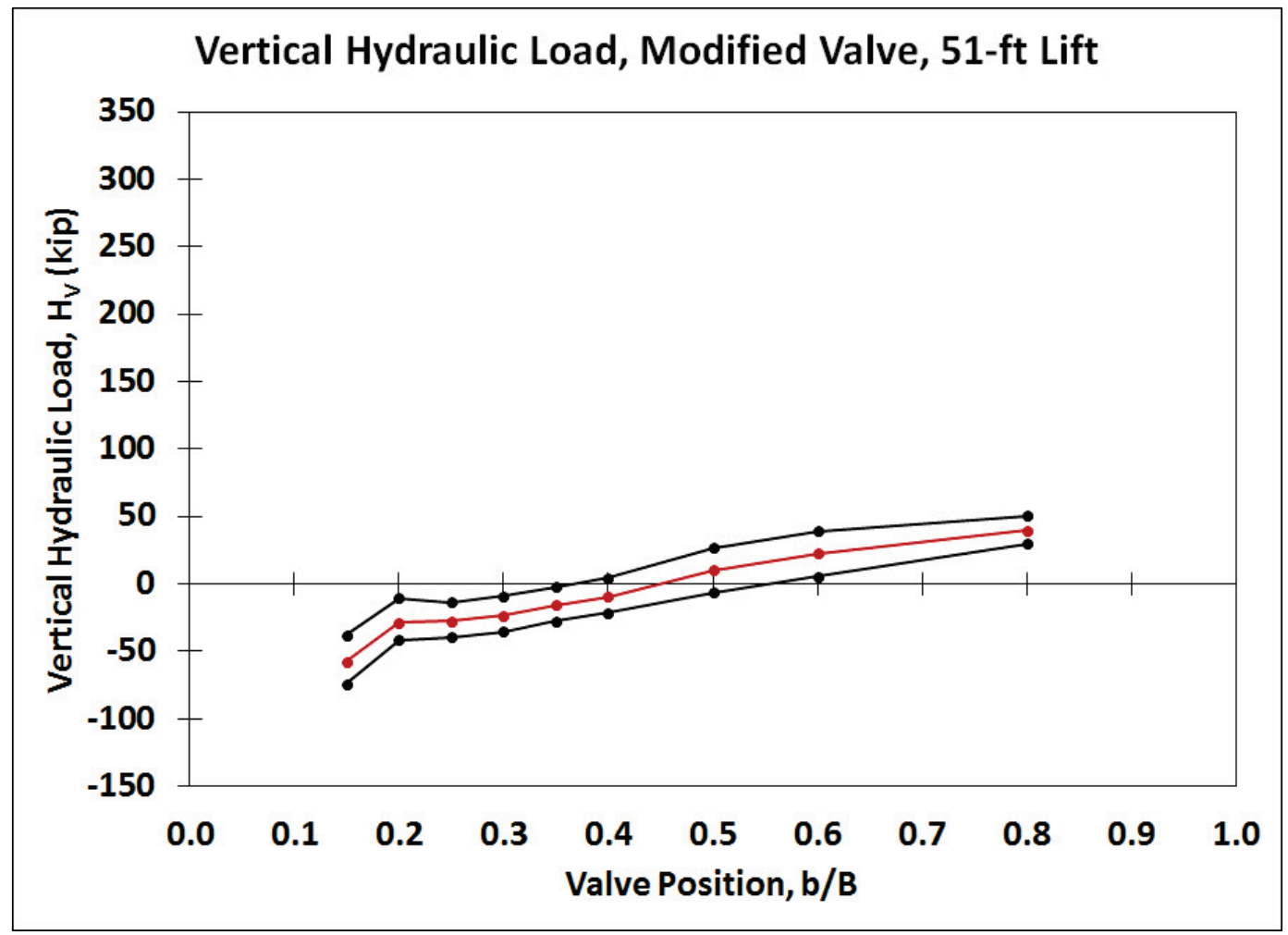


Figure 75 . Modified valve longitudinal hydraulic load $-59 \mathrm{ft}$ lift.

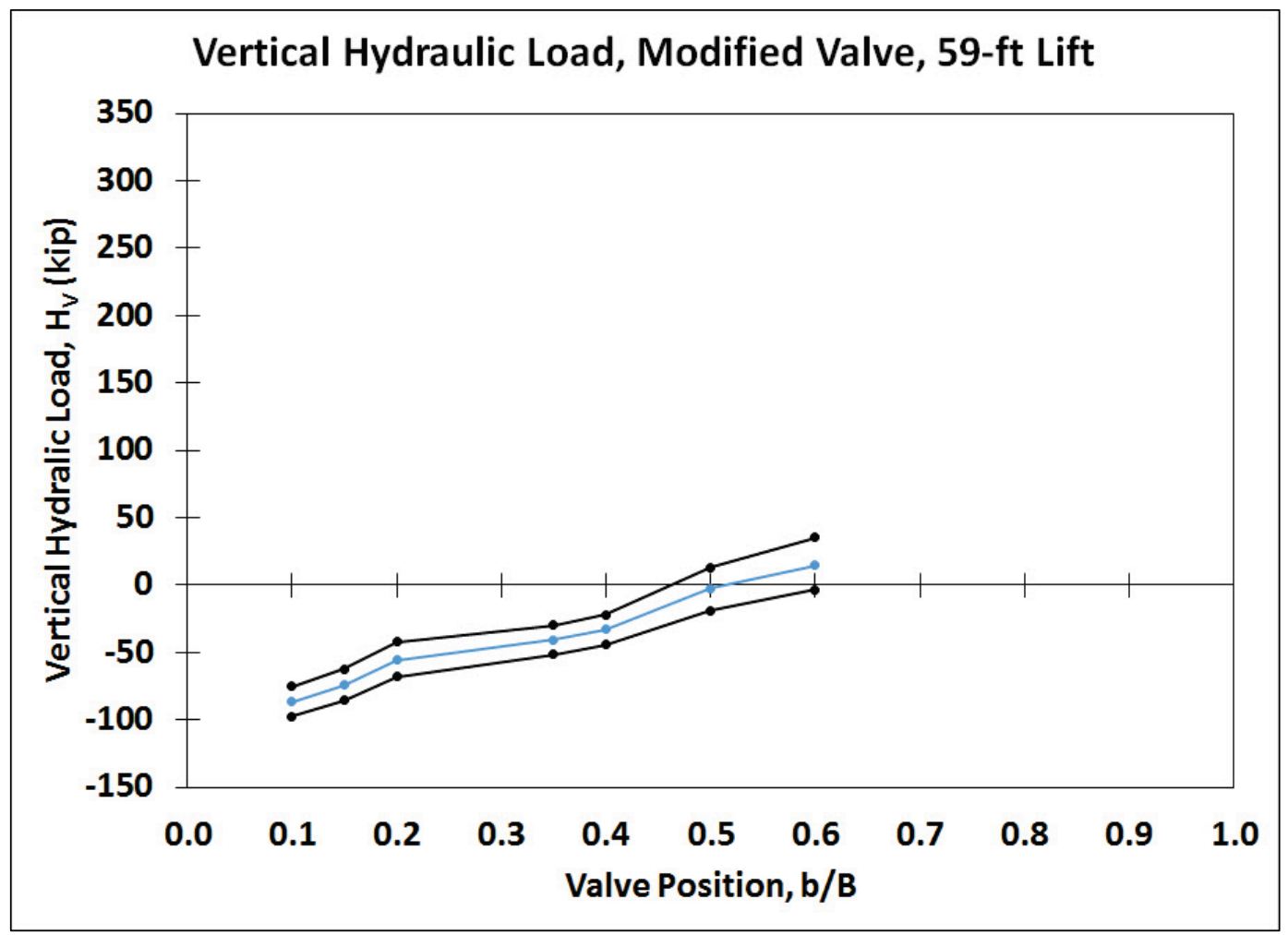

Figure 76. Modified valve longitudinal hydraulic load $-51 \mathrm{ft} \mathrm{lift.}$

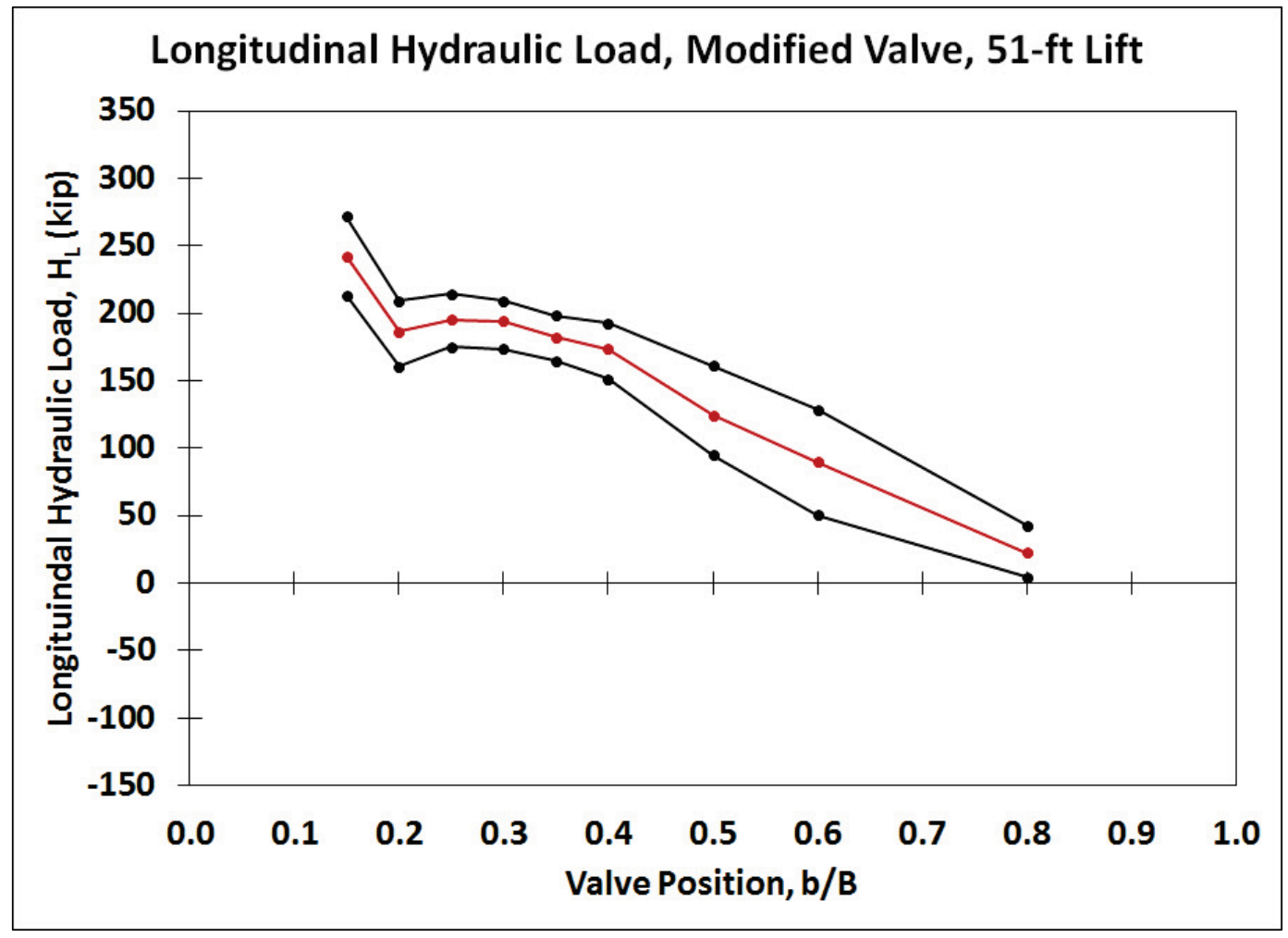


Figure 77. Modified valve longitudinal hydraulic load $-59 \mathrm{ft}$ lift.

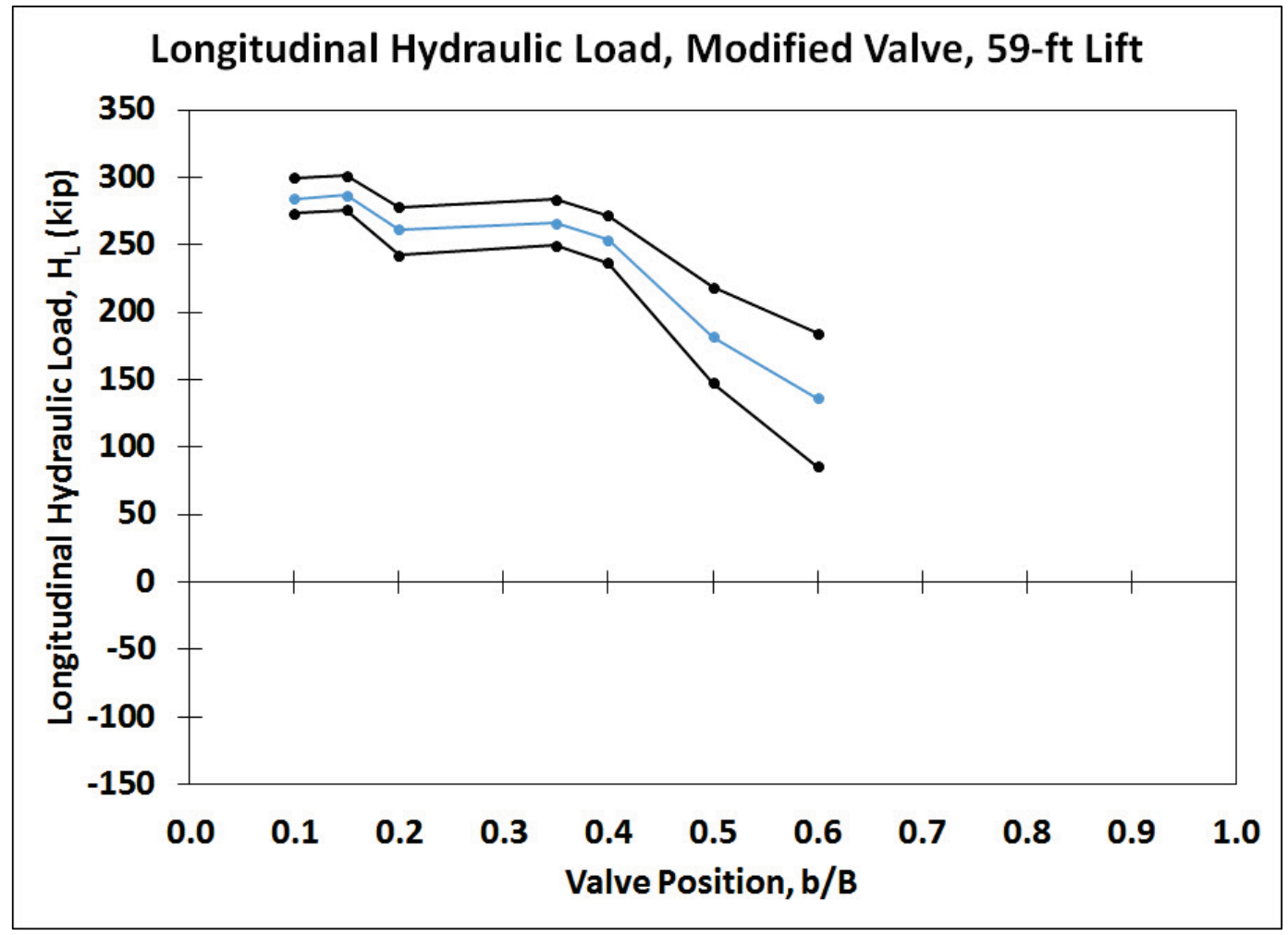

Figure 78. Modified valve resultant hydraulic load $-51 \mathrm{ft}$ lift.

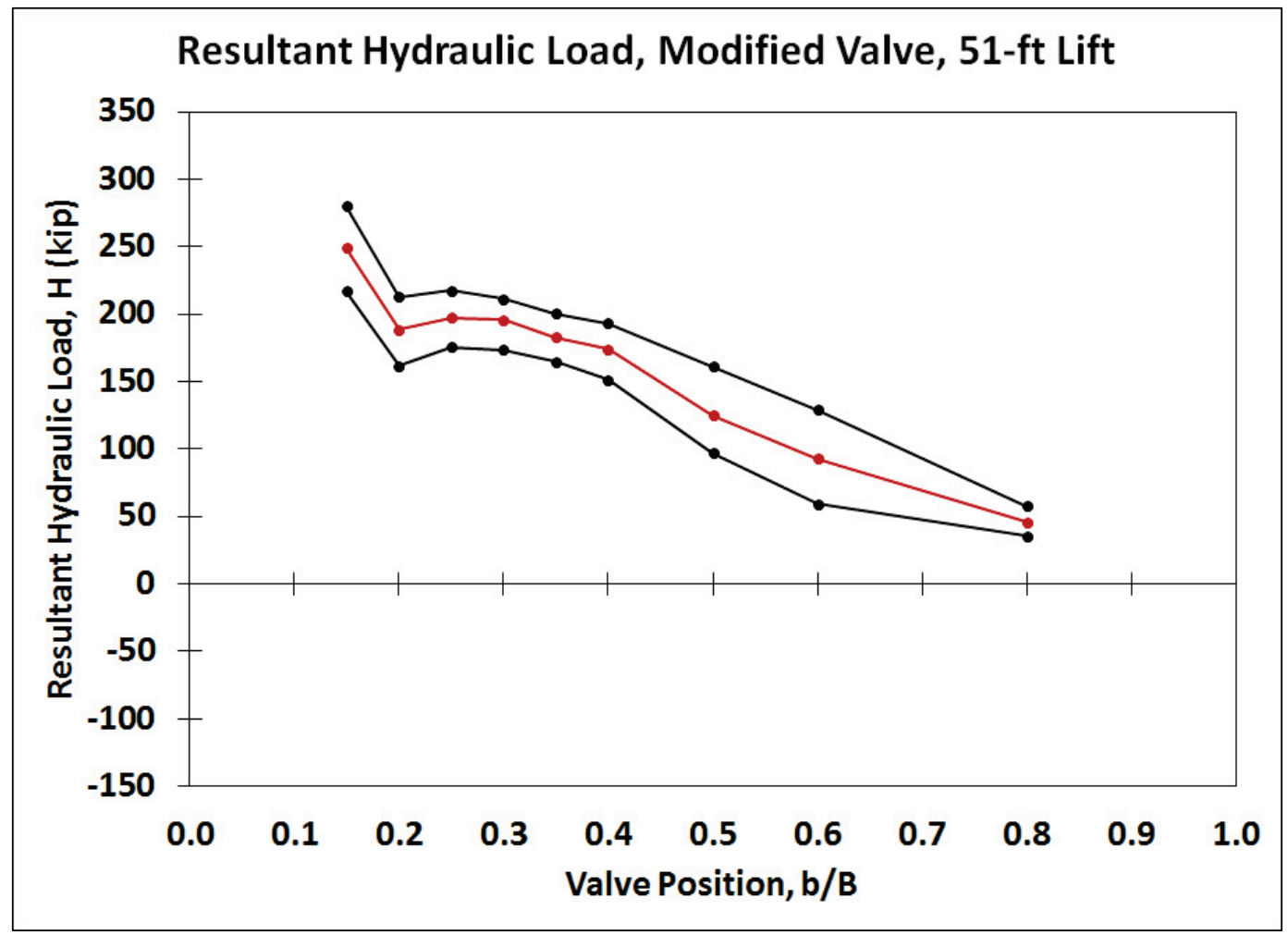


Figure 79. Modified valve resultant hydraulic load $-59 \mathrm{ft}$ lift.

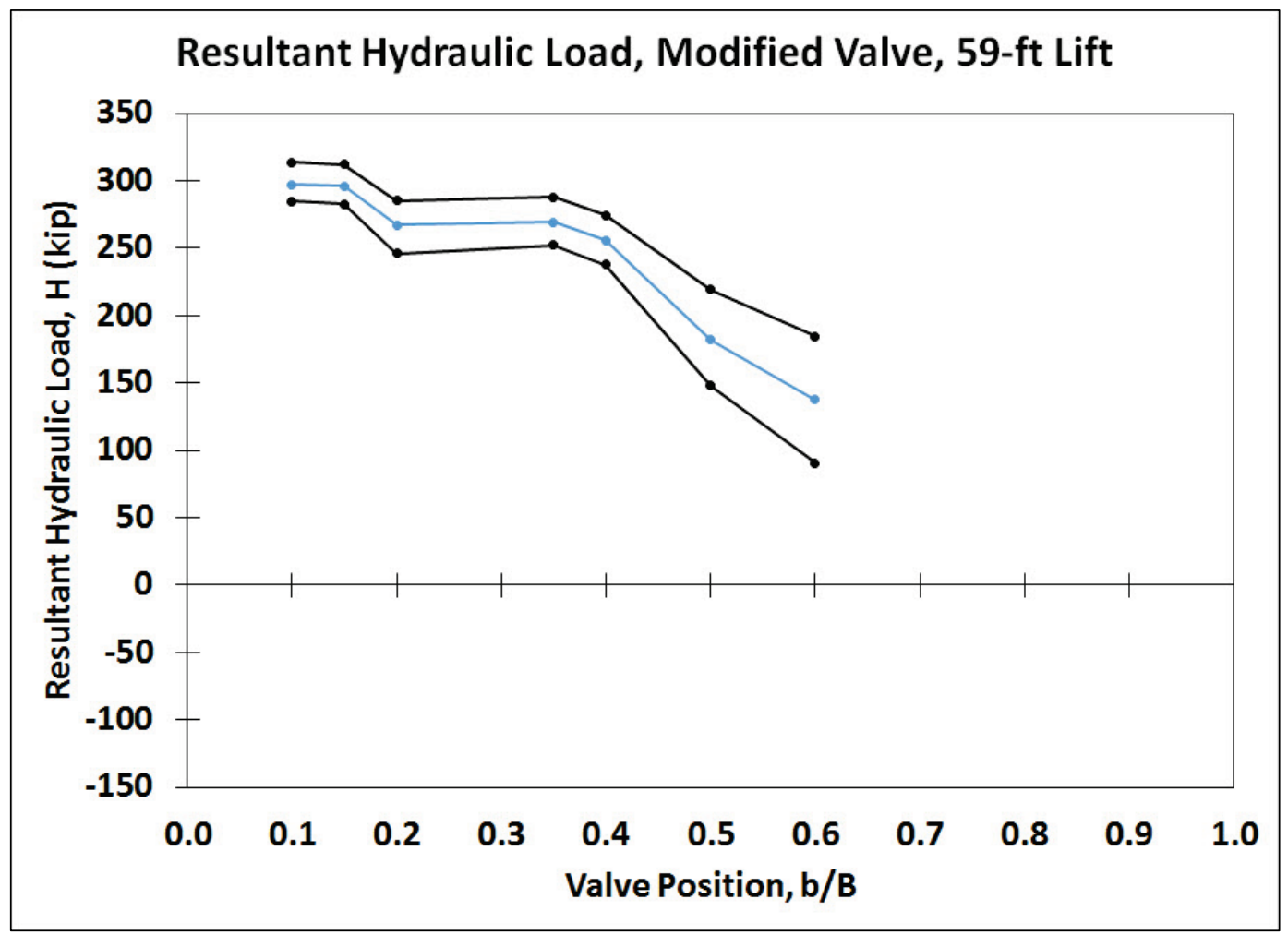

Figure 80. Pressure head distribution along culvert, modified valve, $51 \mathrm{ft} \mathrm{lift.}$

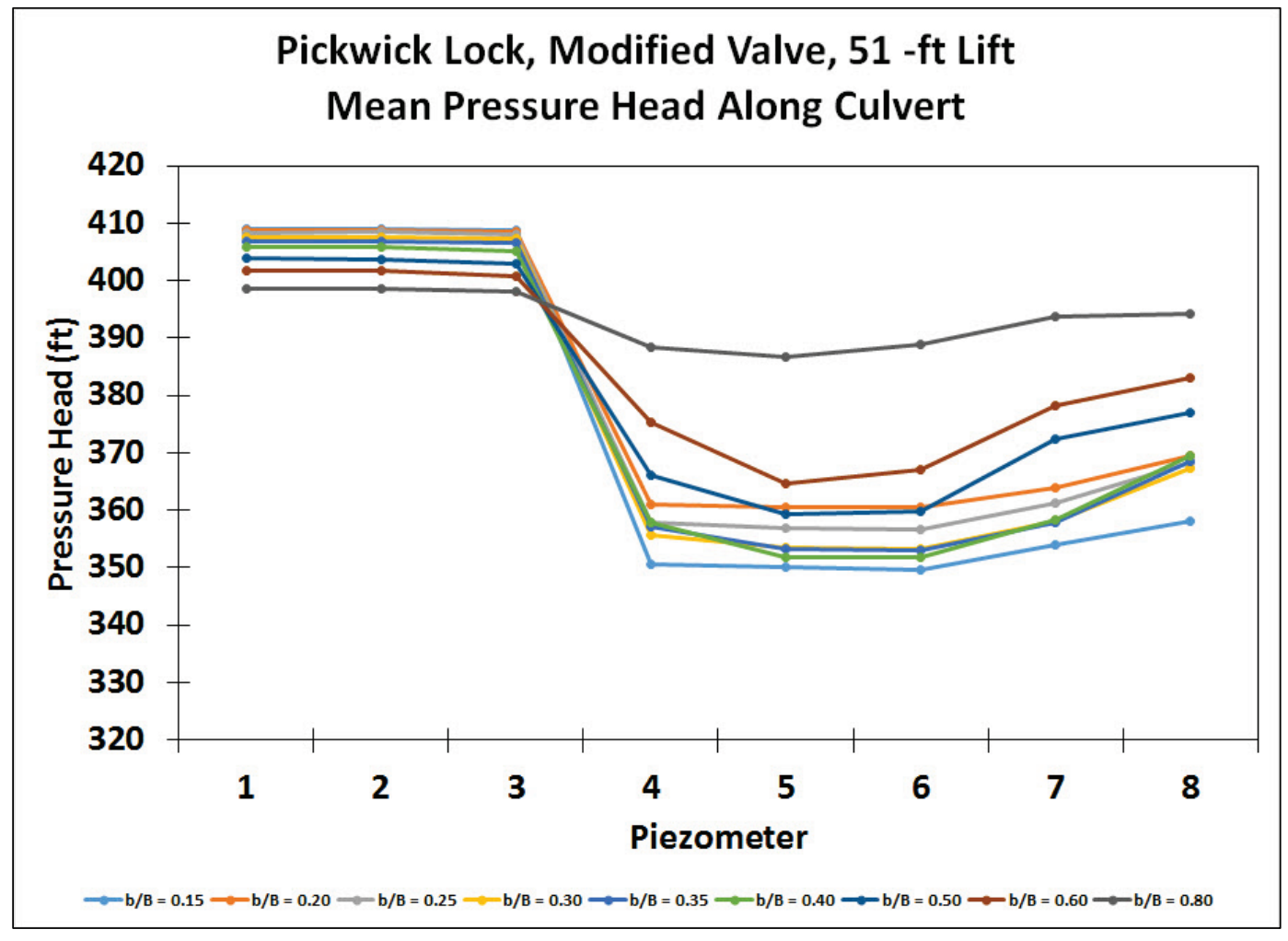


Figure 81. Pressure head distribution along culvert, modified valve, $59 \mathrm{ft}$ lift.

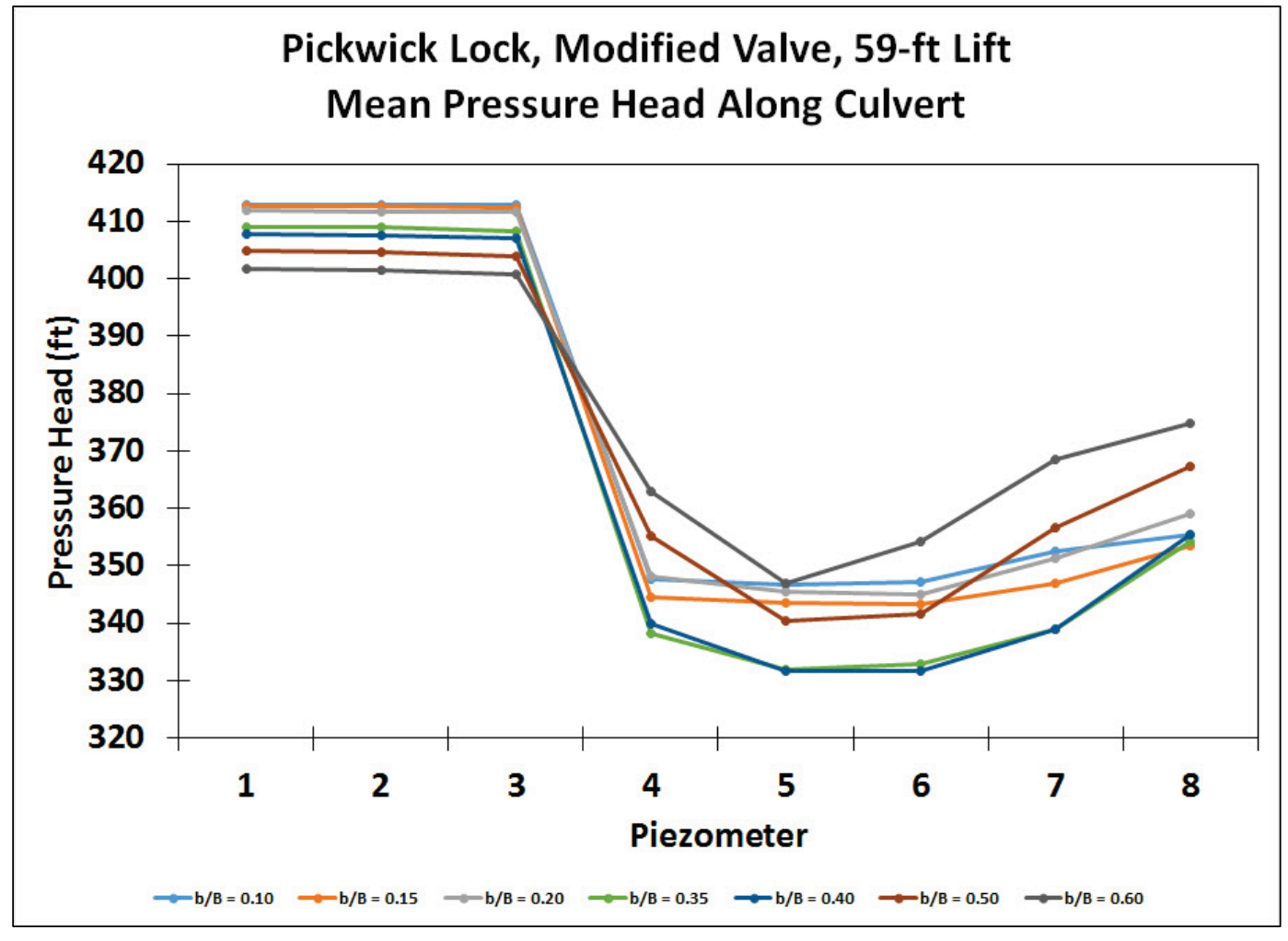




\section{Appendix C: Valve Load Variation Plots}

In this appendix, load variation plots for each quantity and for each lift are presented (Figures 82-101). As described in Section 5.3, these plots are referred to as load variation plots. Each value on these plots represents the difference between the maximum and minimum value for either a measured or calculated quantity from the experiments. For instance, Figure 83 shows the hoist load variation between the existing and modified valve for the $59 \mathrm{ft}$ lift. The green curve represents the existing valve hoist load variation. The point on the existing valve curve for $b / \mathrm{B}=$ 0.10 is $18.4 \mathrm{kips}$, which is the difference in the maximum and minimum hoist loads for point $\mathrm{b} / \mathrm{B}=0.10$ (19.7 and $1.3 \mathrm{kips}$ from Table 4). The same process is followed using the data from the modified valve to produce the orange curve for the modified valve. Rather than the value of each point, these plots are included to show the relative difference in the load variation between the existing and modified valve. Smaller values indicate lower valve vibration amplitudes.

Figure 82 . Hoist load variation between valves $-51 \mathrm{ft}$ lift.

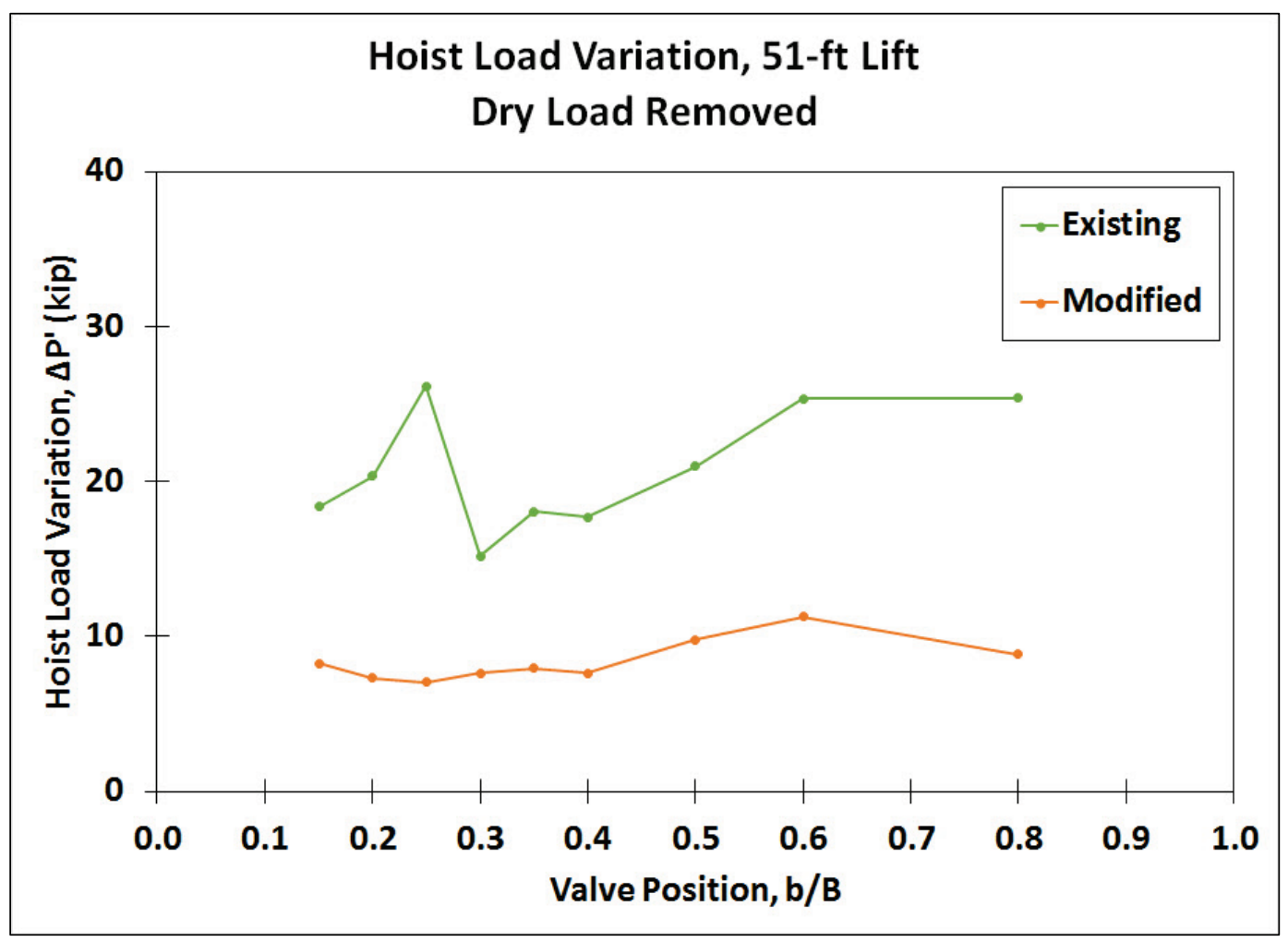


Figure 83. Hoist load variation between valves $-59 \mathrm{ft}$ lift.

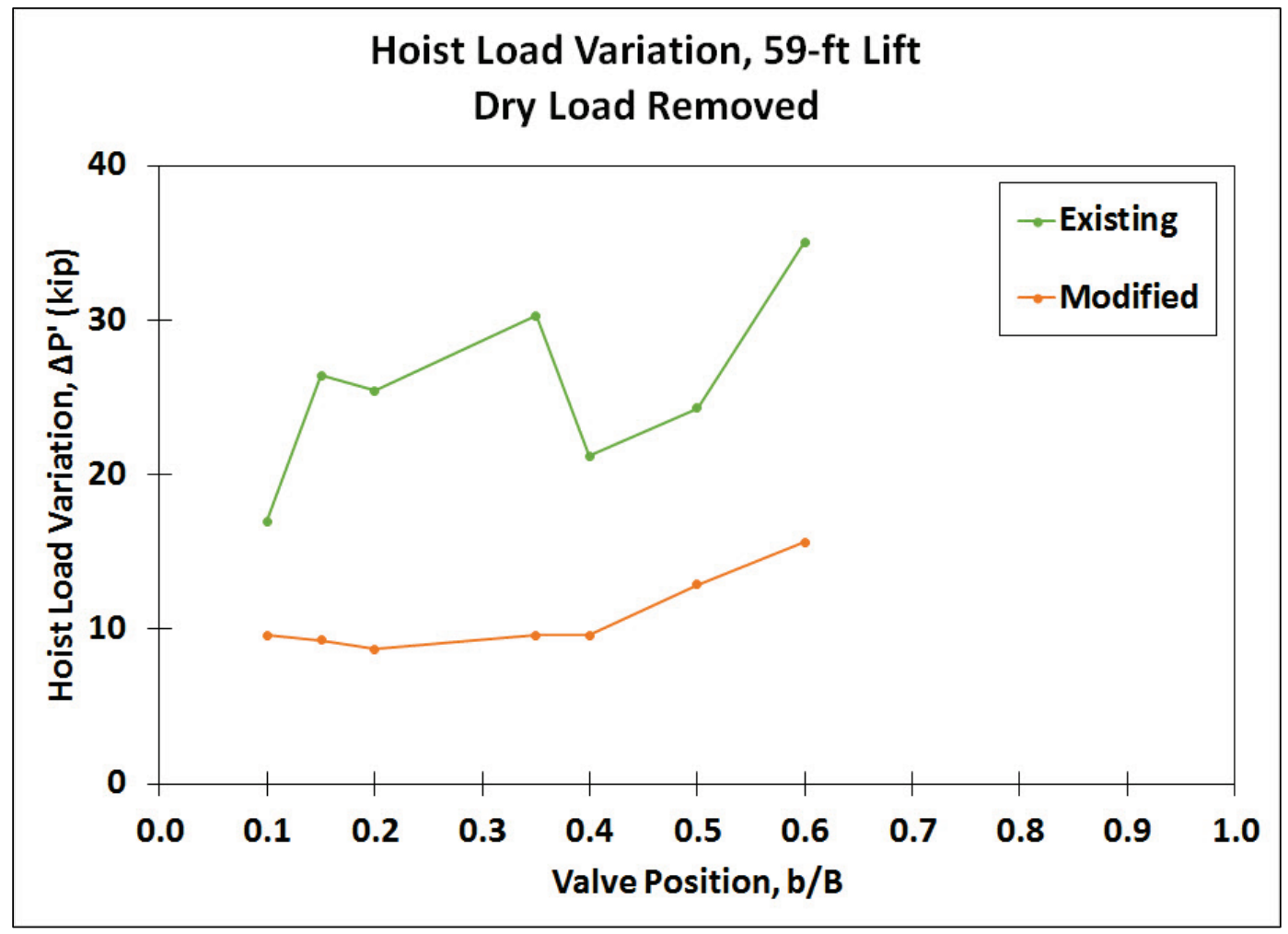

Figure 84. Vertical trunnion load variation between valves $-51 \mathrm{ft} \mathrm{lift.}$

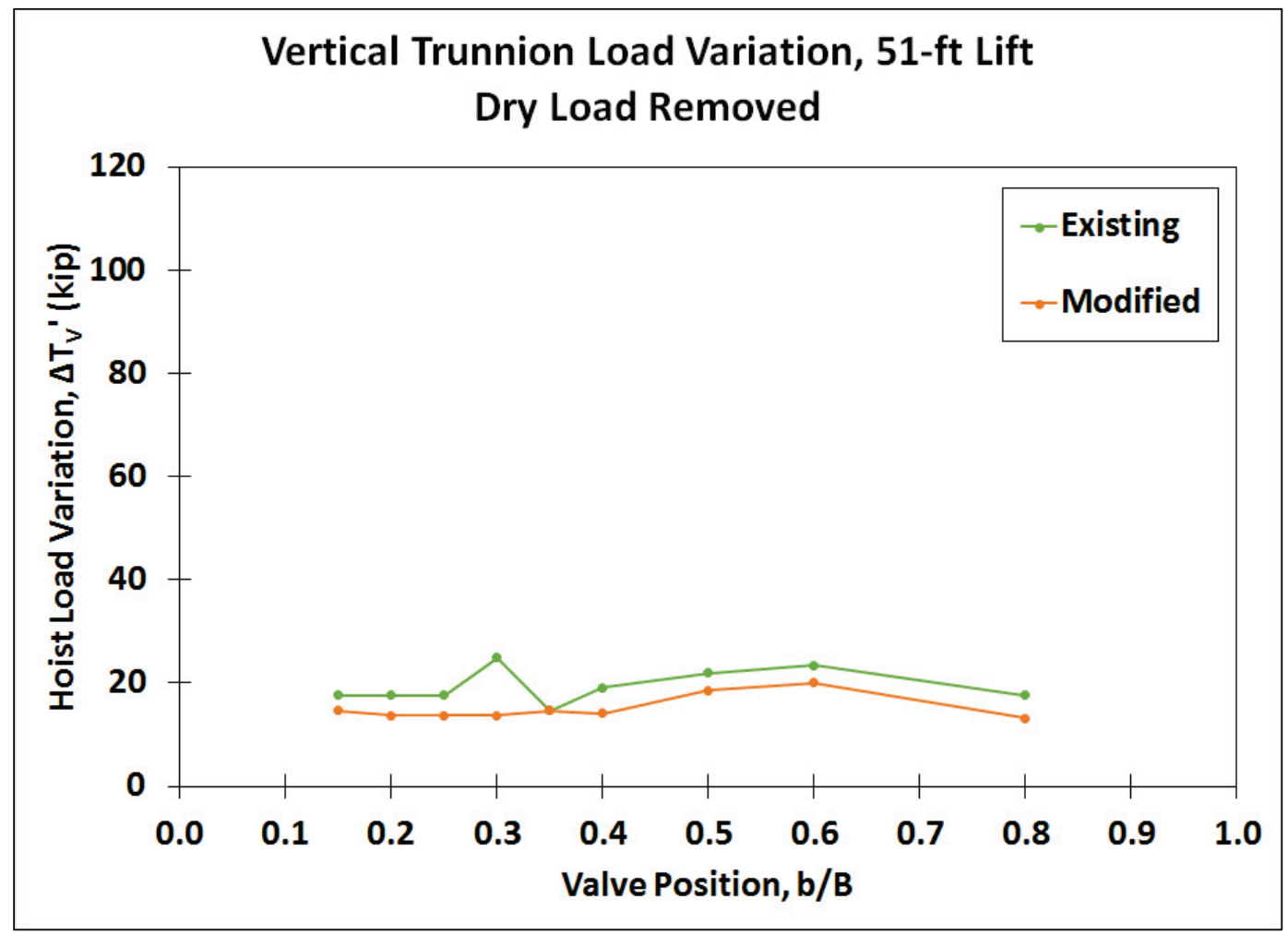


Figure 85 . Vertical trunnion load variation between valves $-59 \mathrm{ft}$ lift.

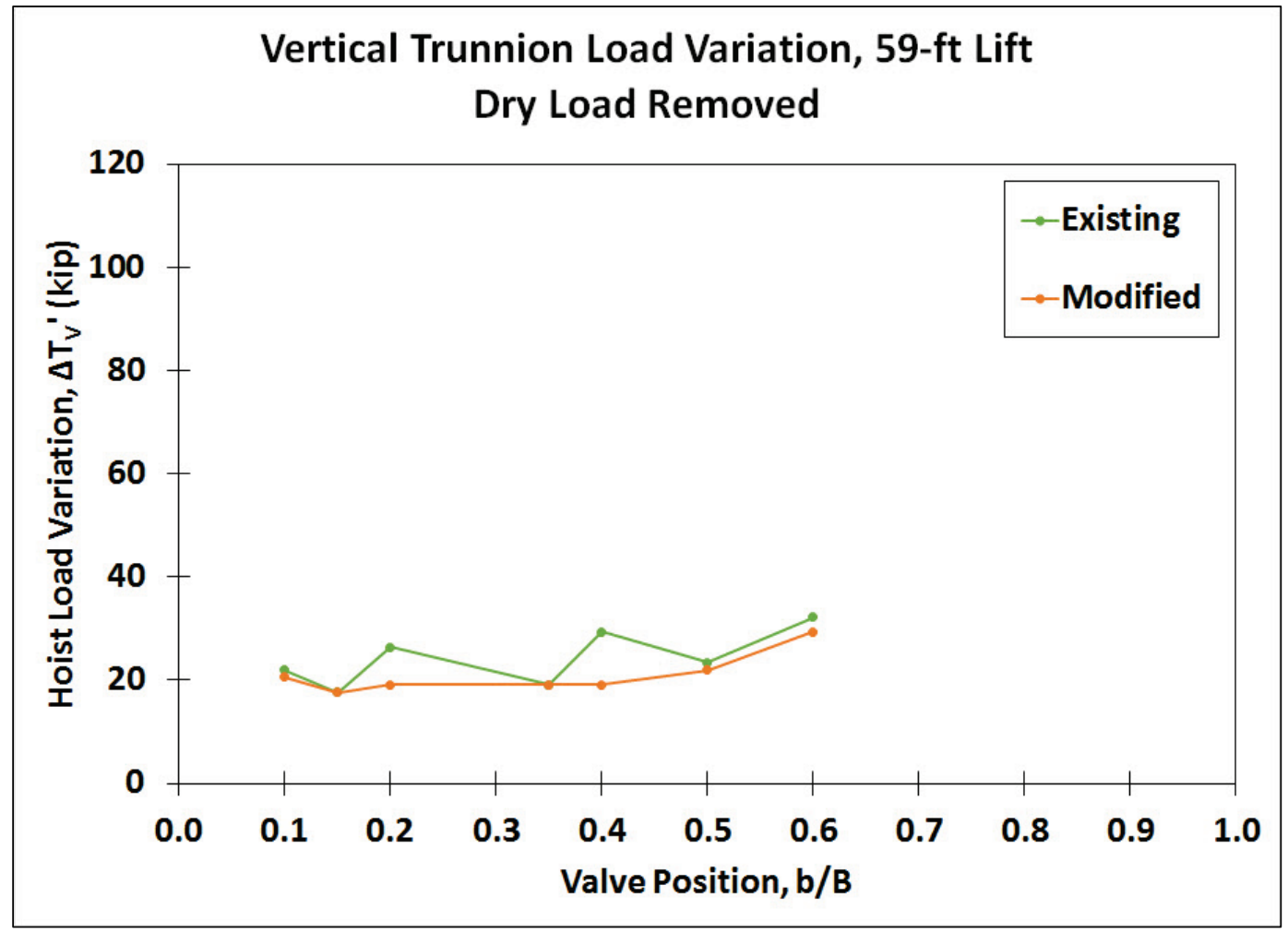

Figure 86. Longitudinal trunnion load variation between valves $-51 \mathrm{ft} \mathrm{lift}$.

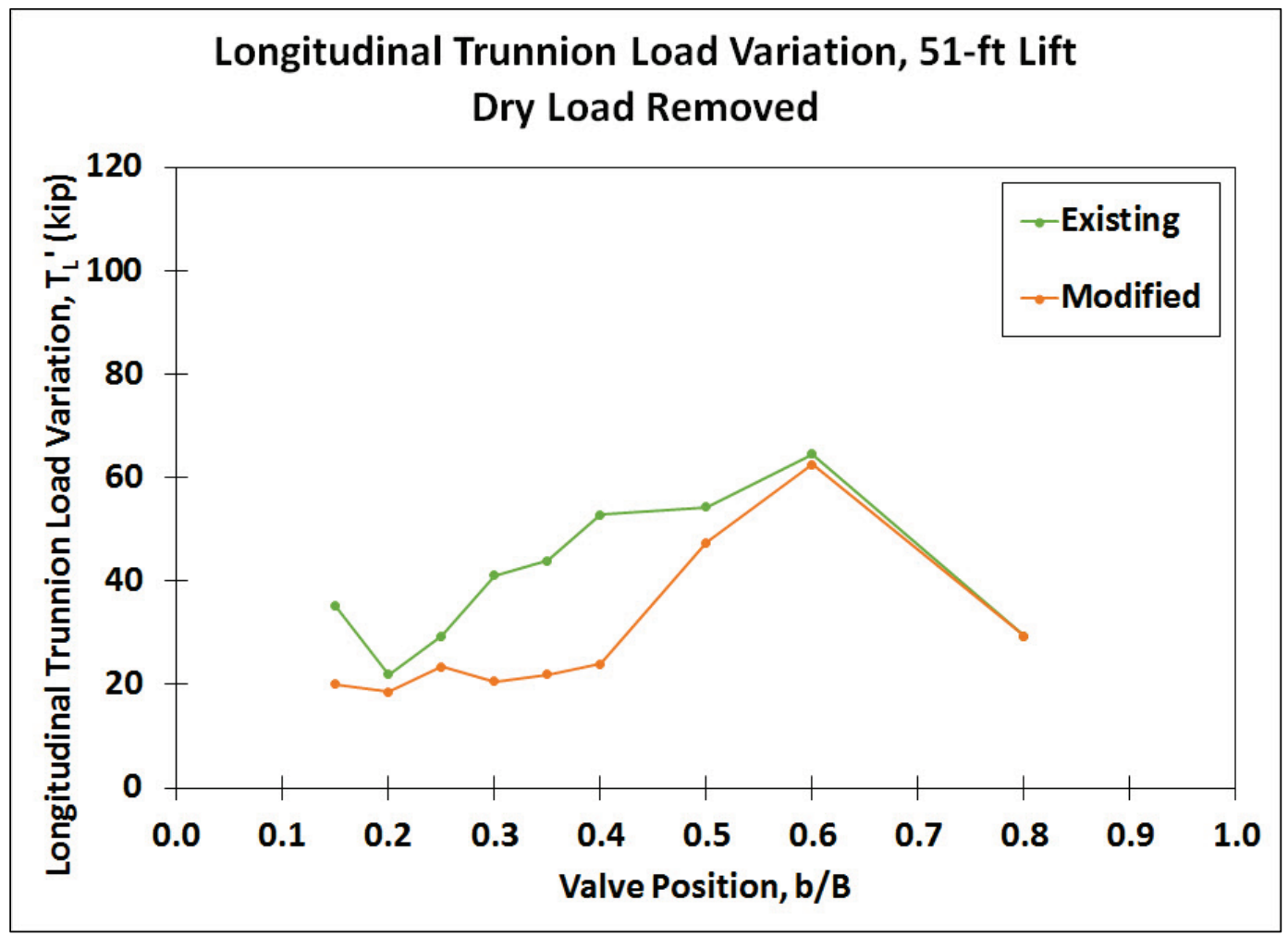


Figure 87. Longitudinal trunnion load variation between valves $-59 \mathrm{ft}$ lift.

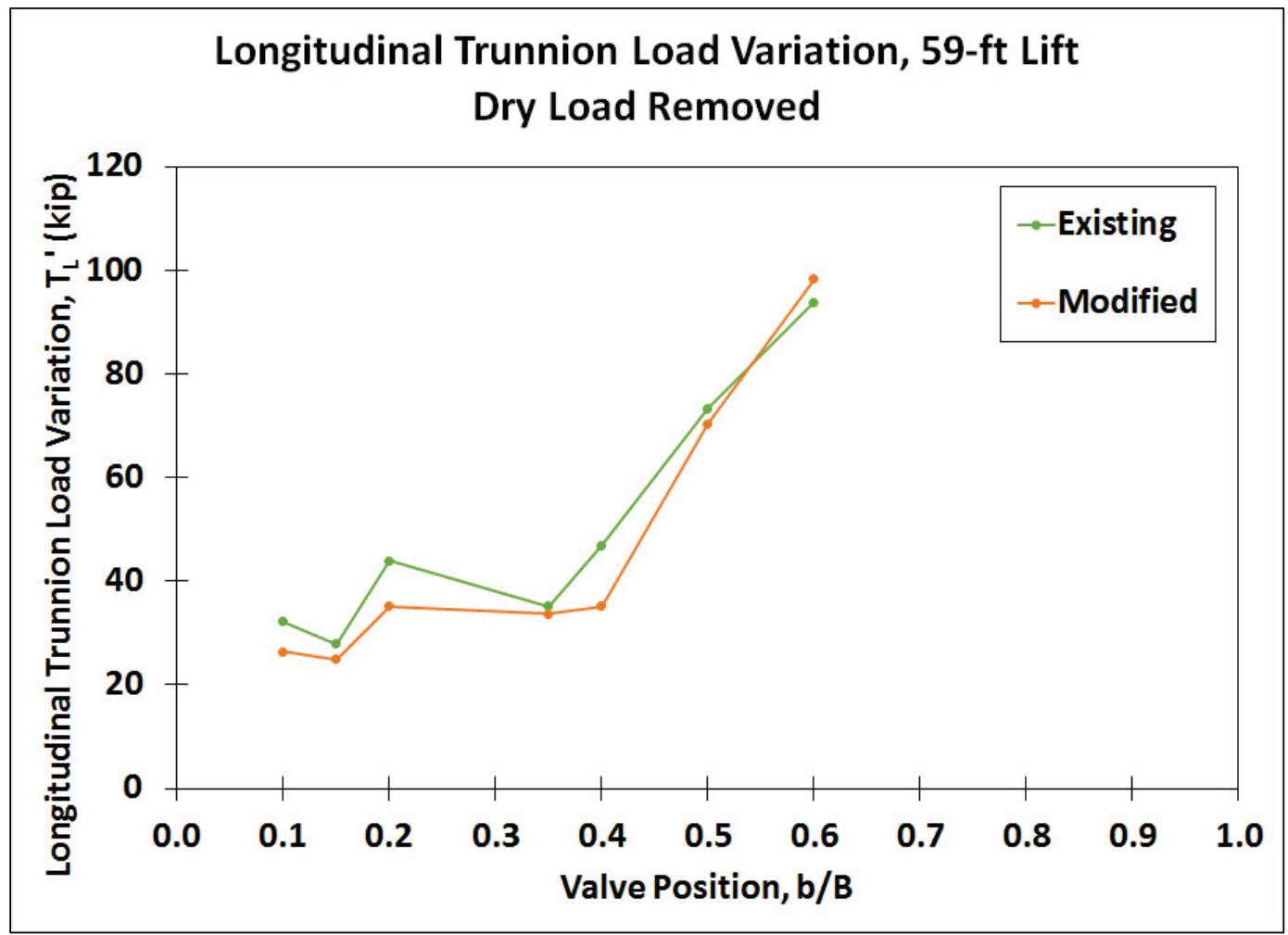

Figure 88. Resultant trunnion load variation between valves $-51 \mathrm{ft} \mathrm{lift}$.

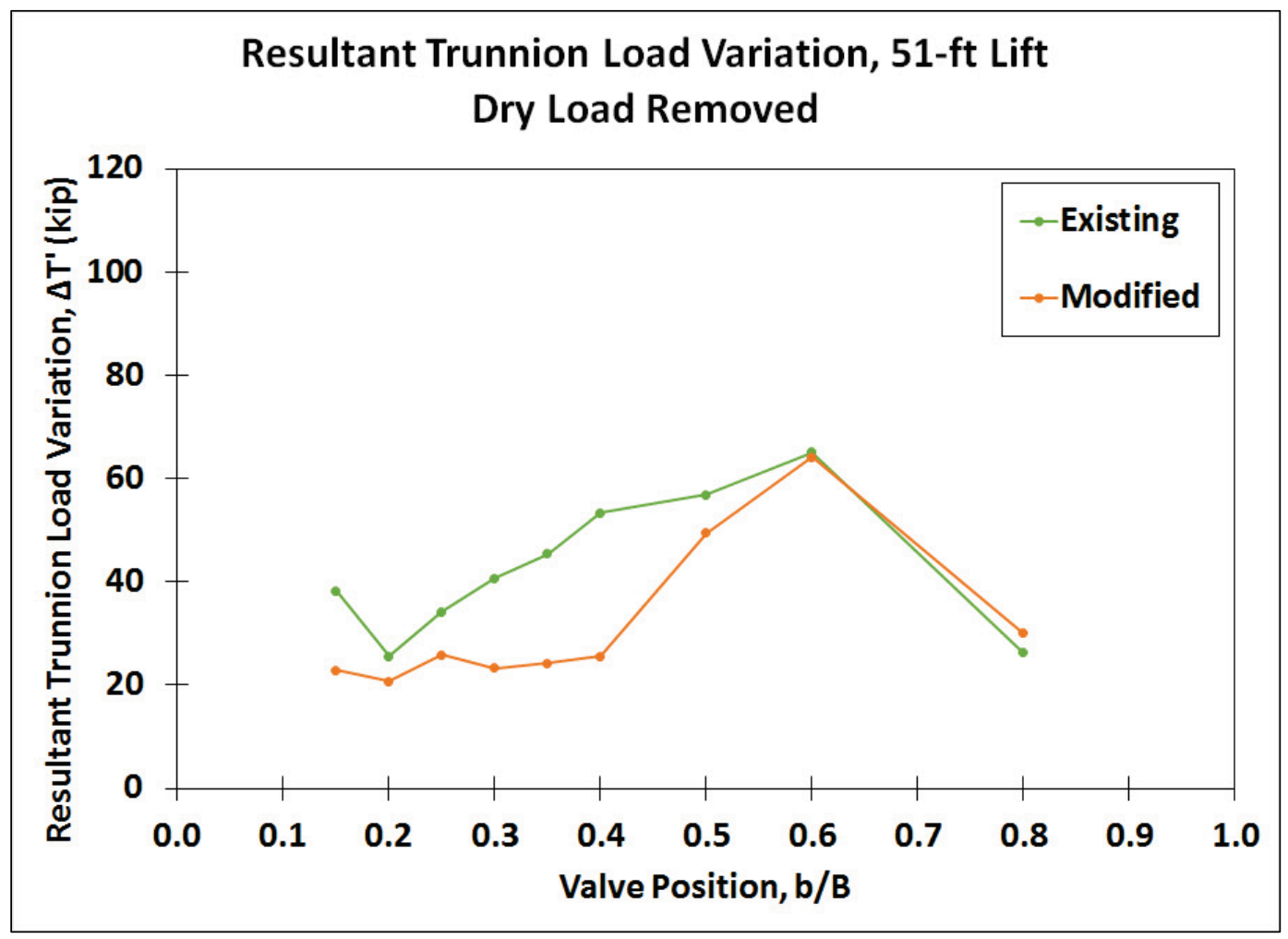


Figure 89. Resultant trunnion load variation between valves $-59 \mathrm{ft}$ lift.

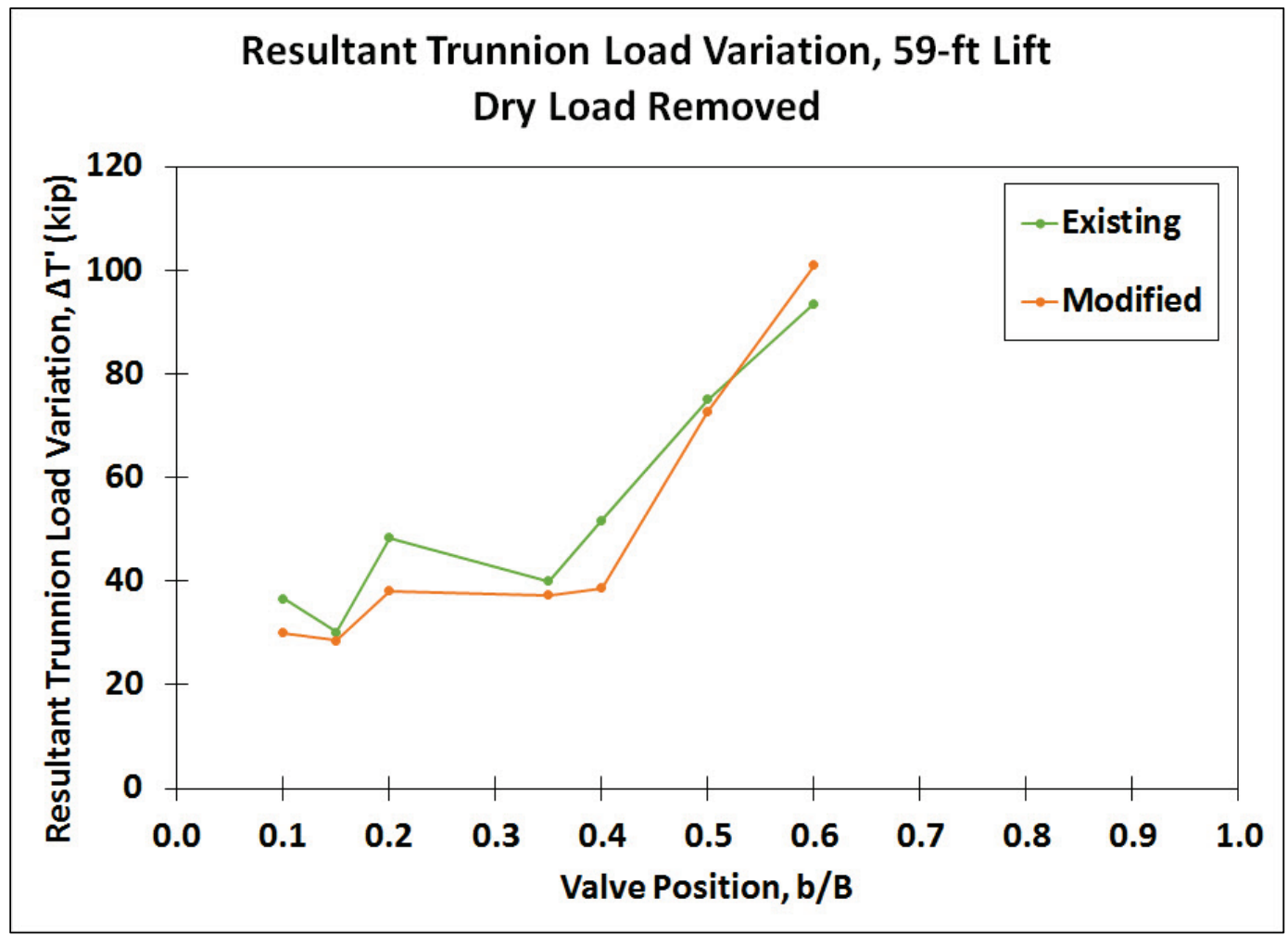

Figure 90 . Vertical trunnion end load variation between valves $-51 \mathrm{ft}$ lift.

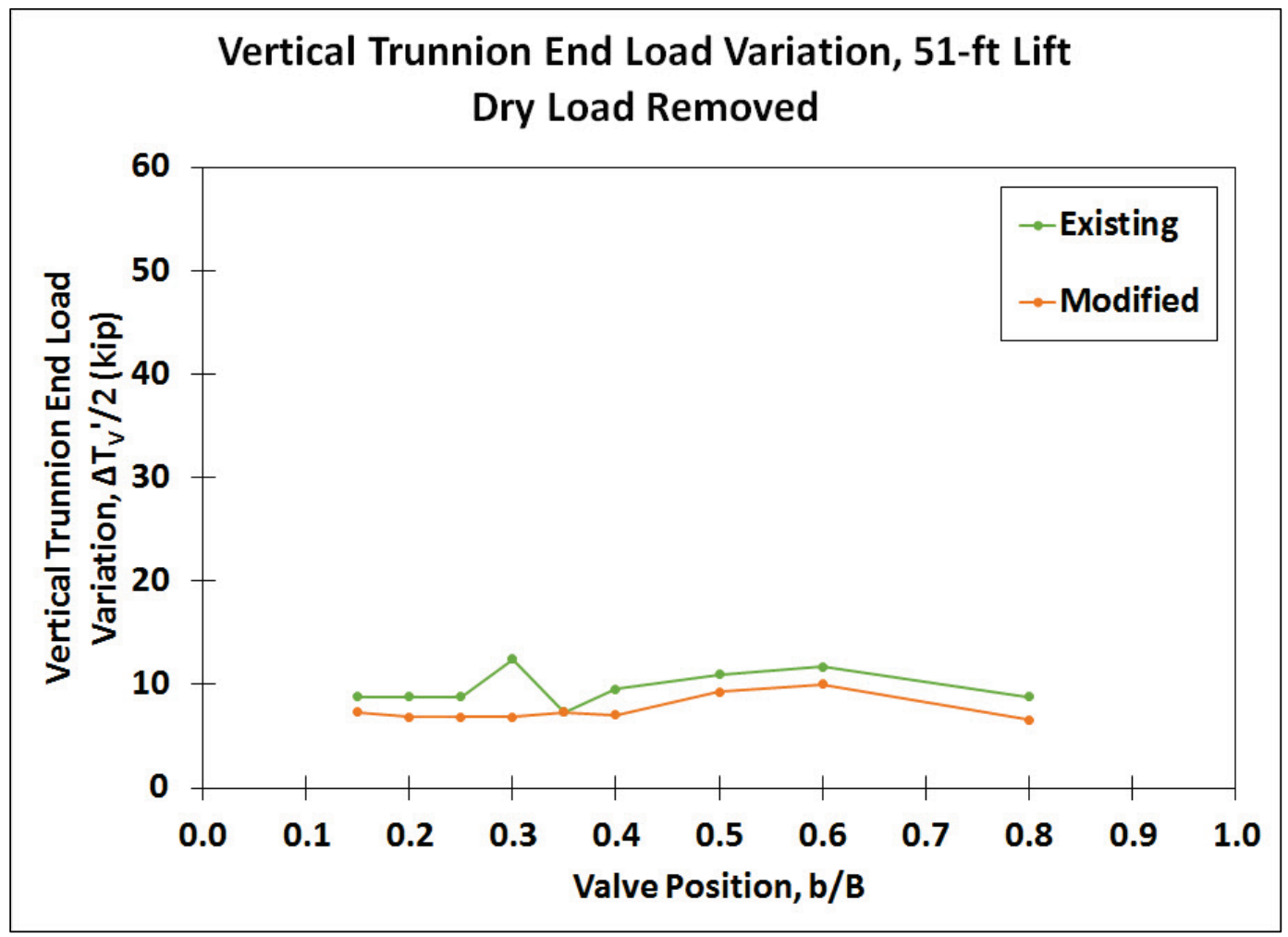


Figure 91. Vertical trunnion end load variation between valves $-59 \mathrm{ft}$ lift.

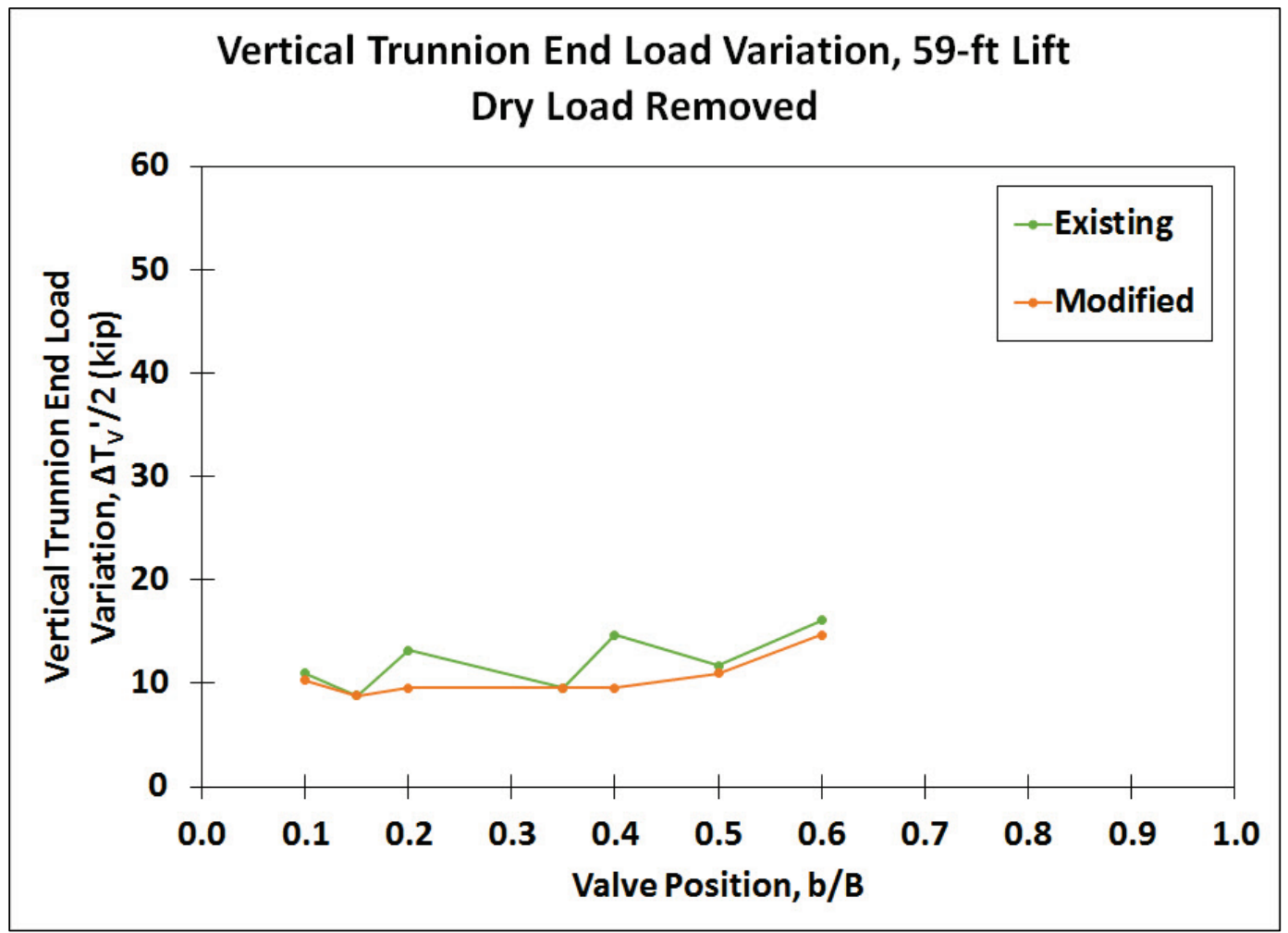

Figure 92. Longitudinal trunnion end load variation between valves $-51 \mathrm{ft} \mathrm{lift.}$

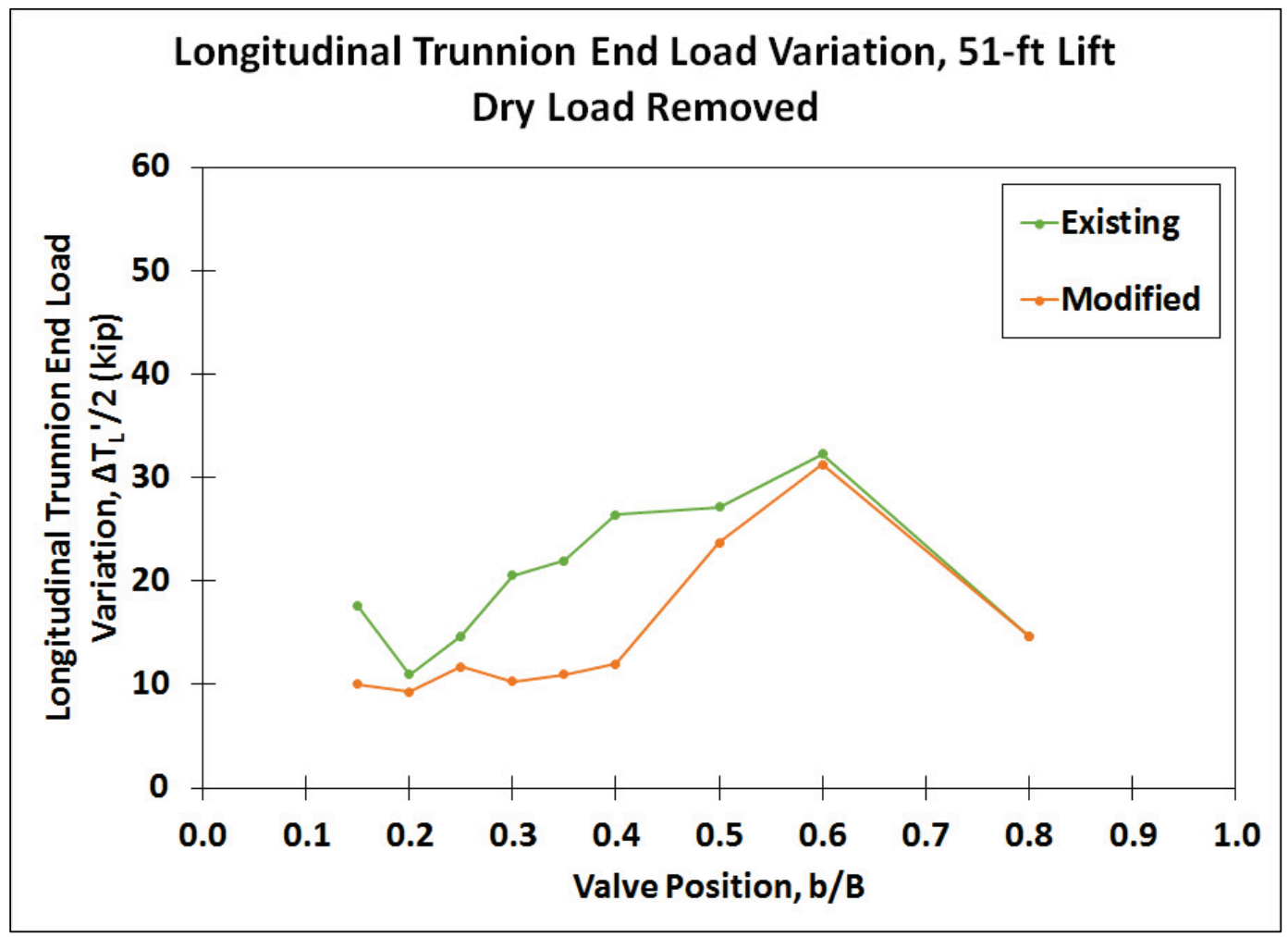


Figure 93. Longitudinal trunnion end load variation between valves $-59 \mathrm{ft}$ lift.

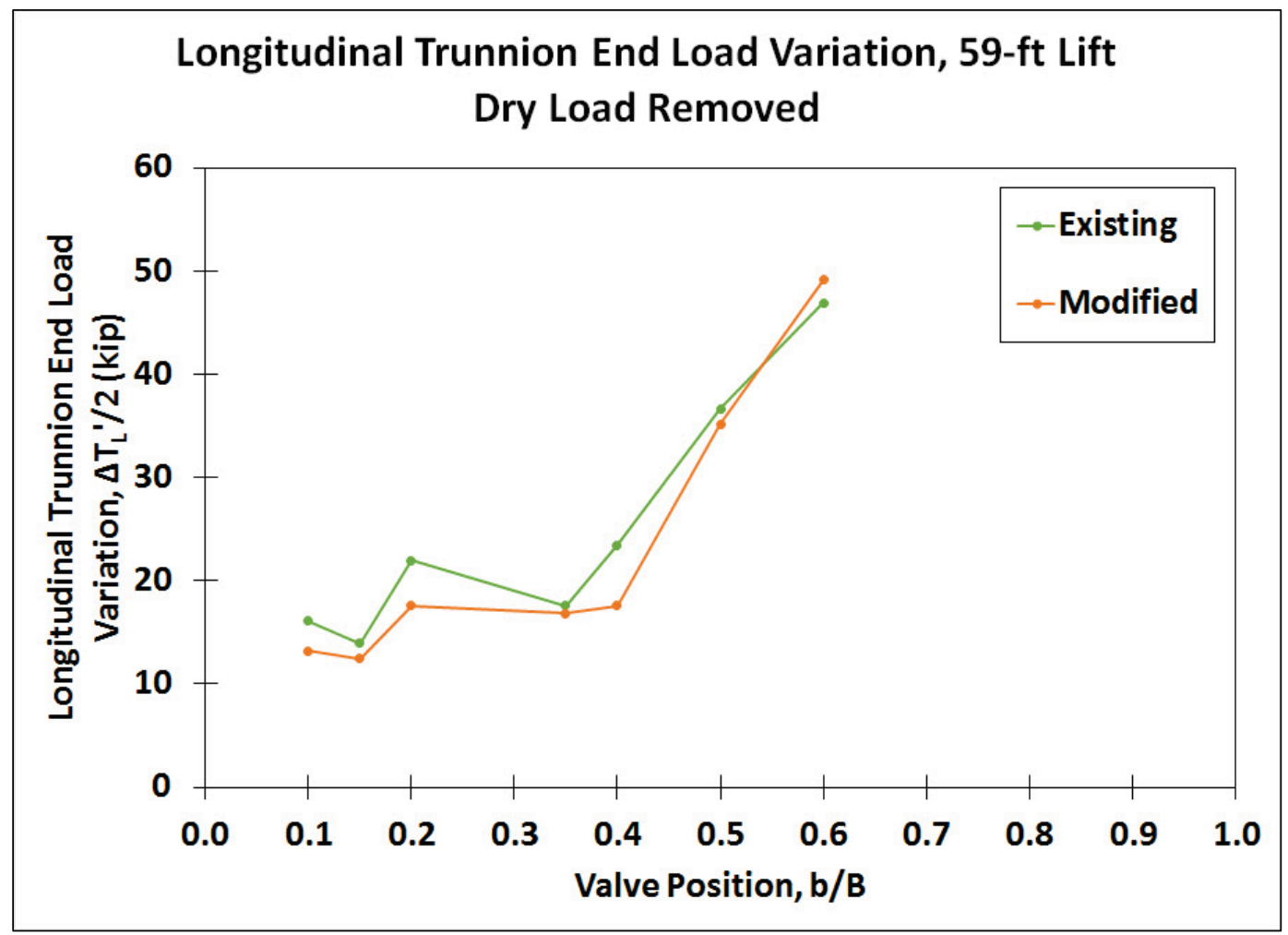

Figure 94. Resultant trunnion end load variation between valves $-59 \mathrm{ft} \mathrm{lift}$.

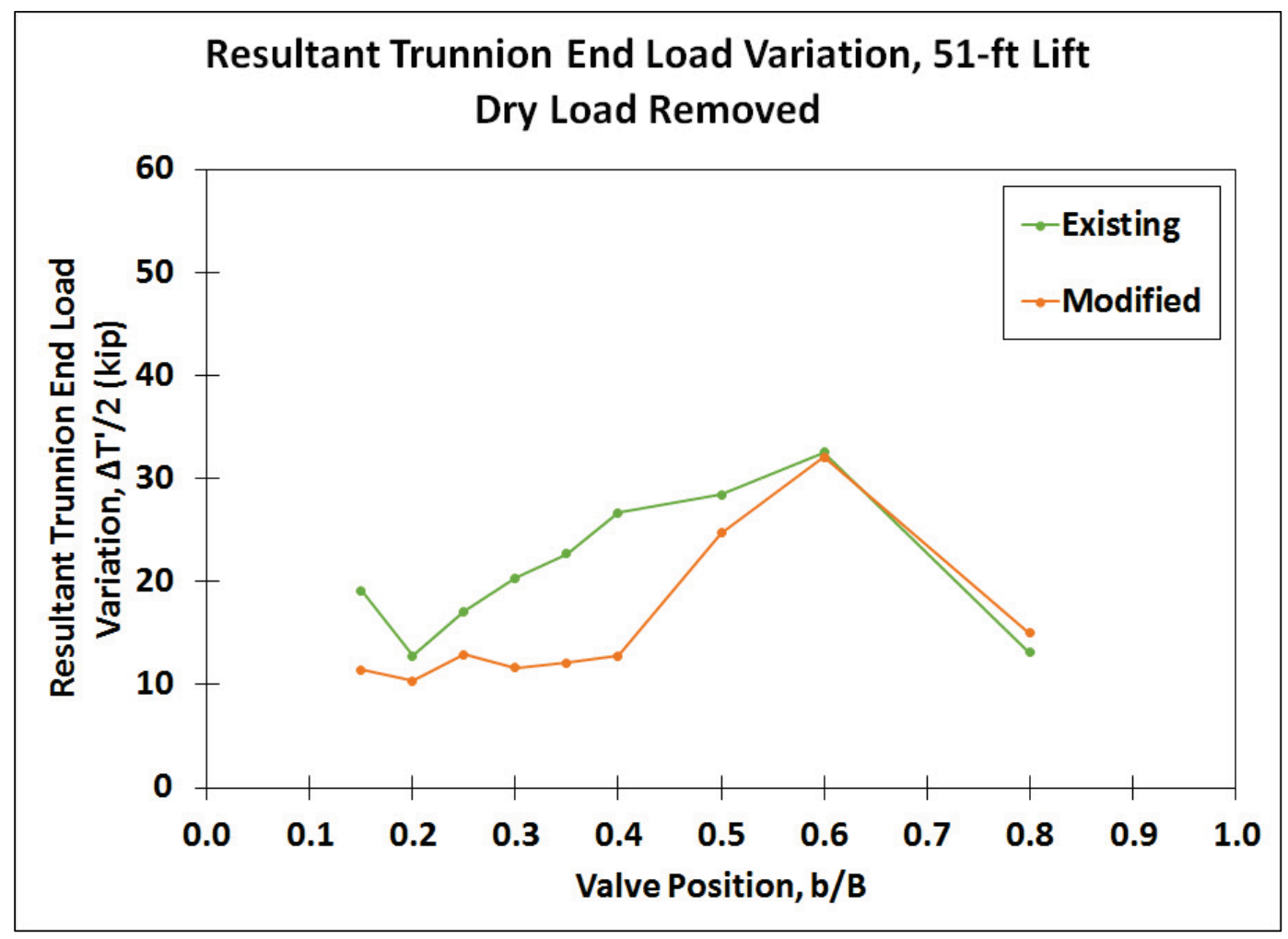


Figure 95. Resultant trunnion end load variation between valves $-59 \mathrm{ft}$ lift.

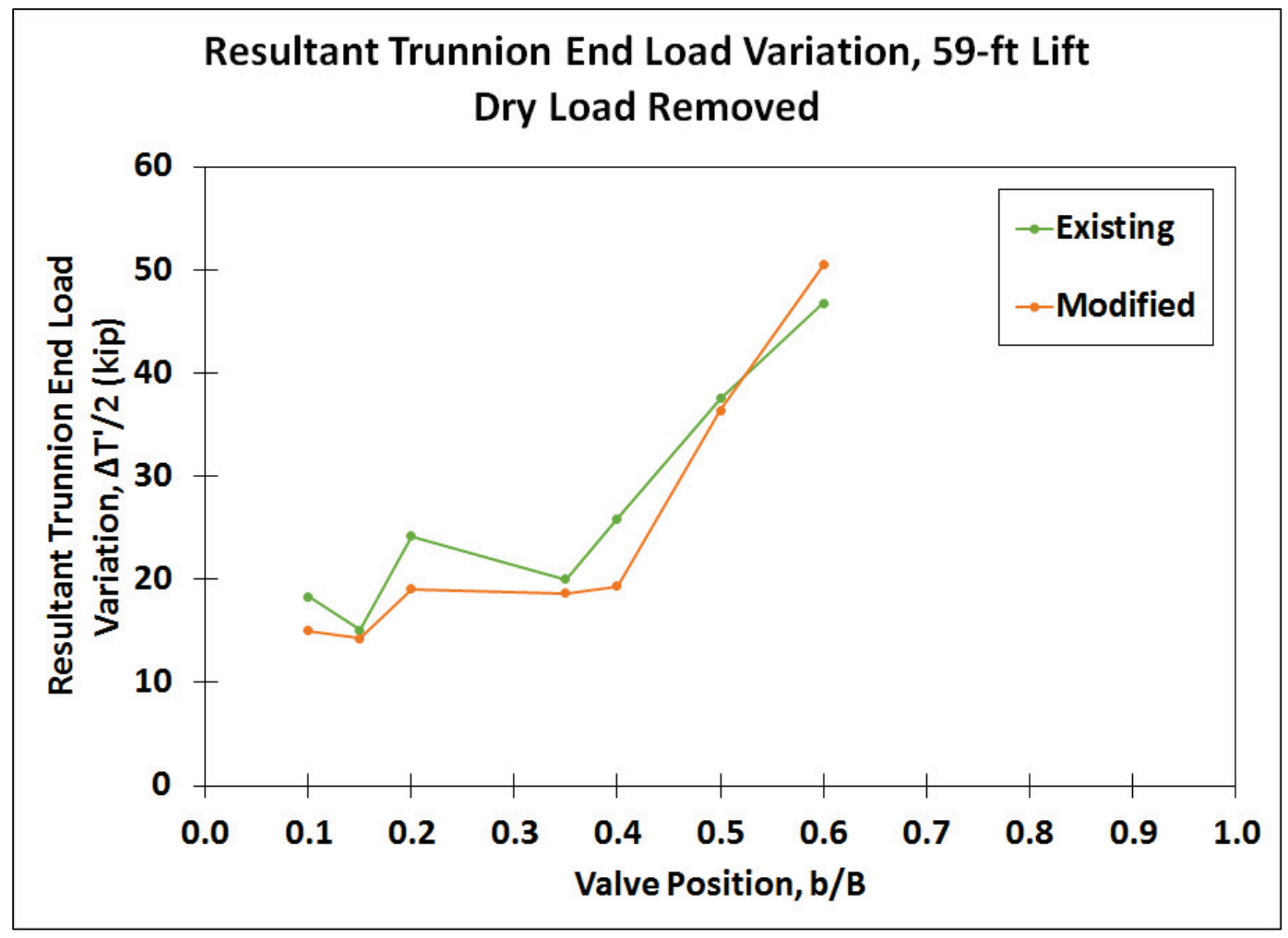

Figure 96 . Vertical hydraulic load variation between valves $-51 \mathrm{ft} \mathrm{lift.}$

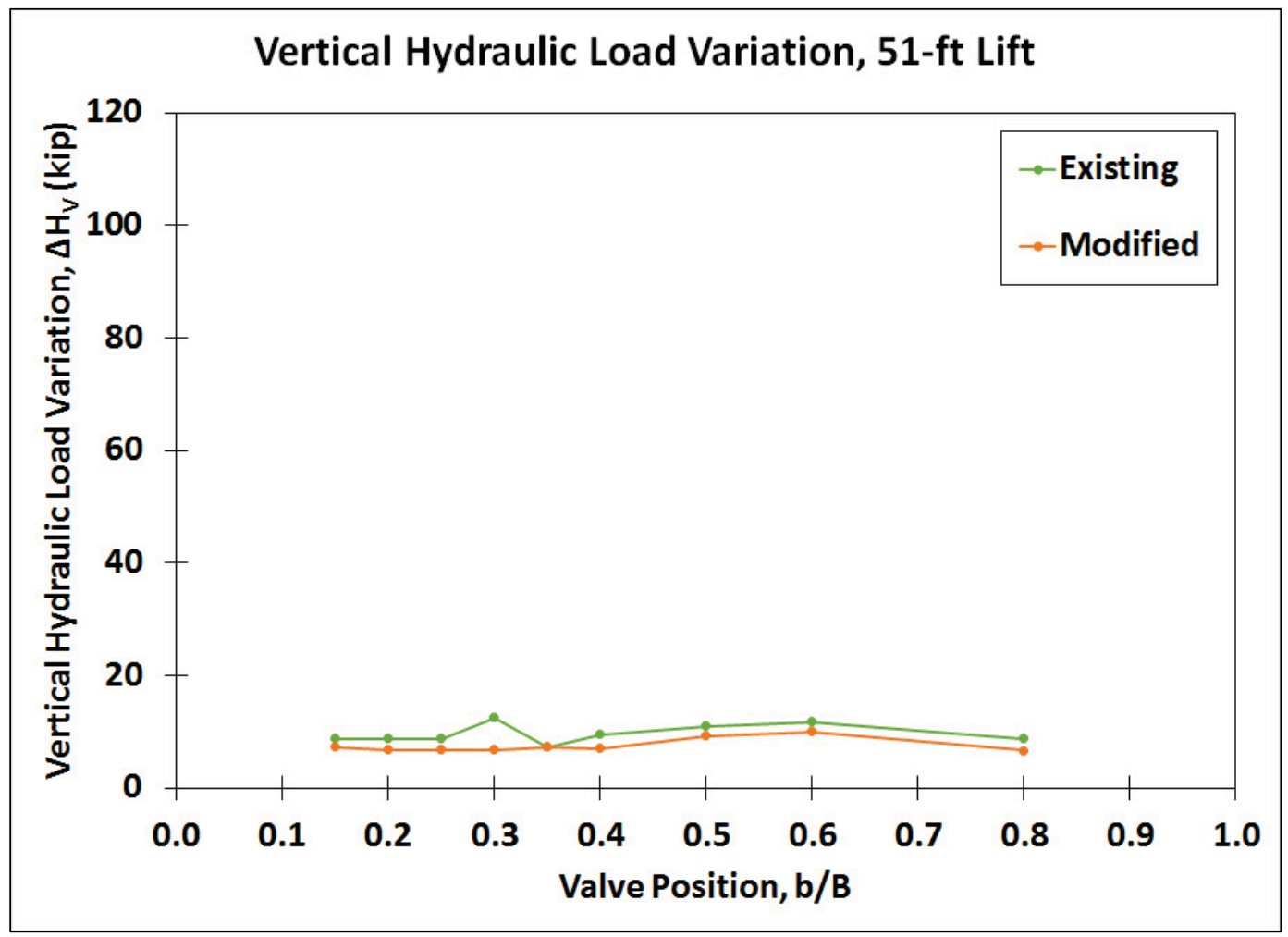


Figure 97 . Vertical hydraulic load variation between valves $-59 \mathrm{ft}$ lift.

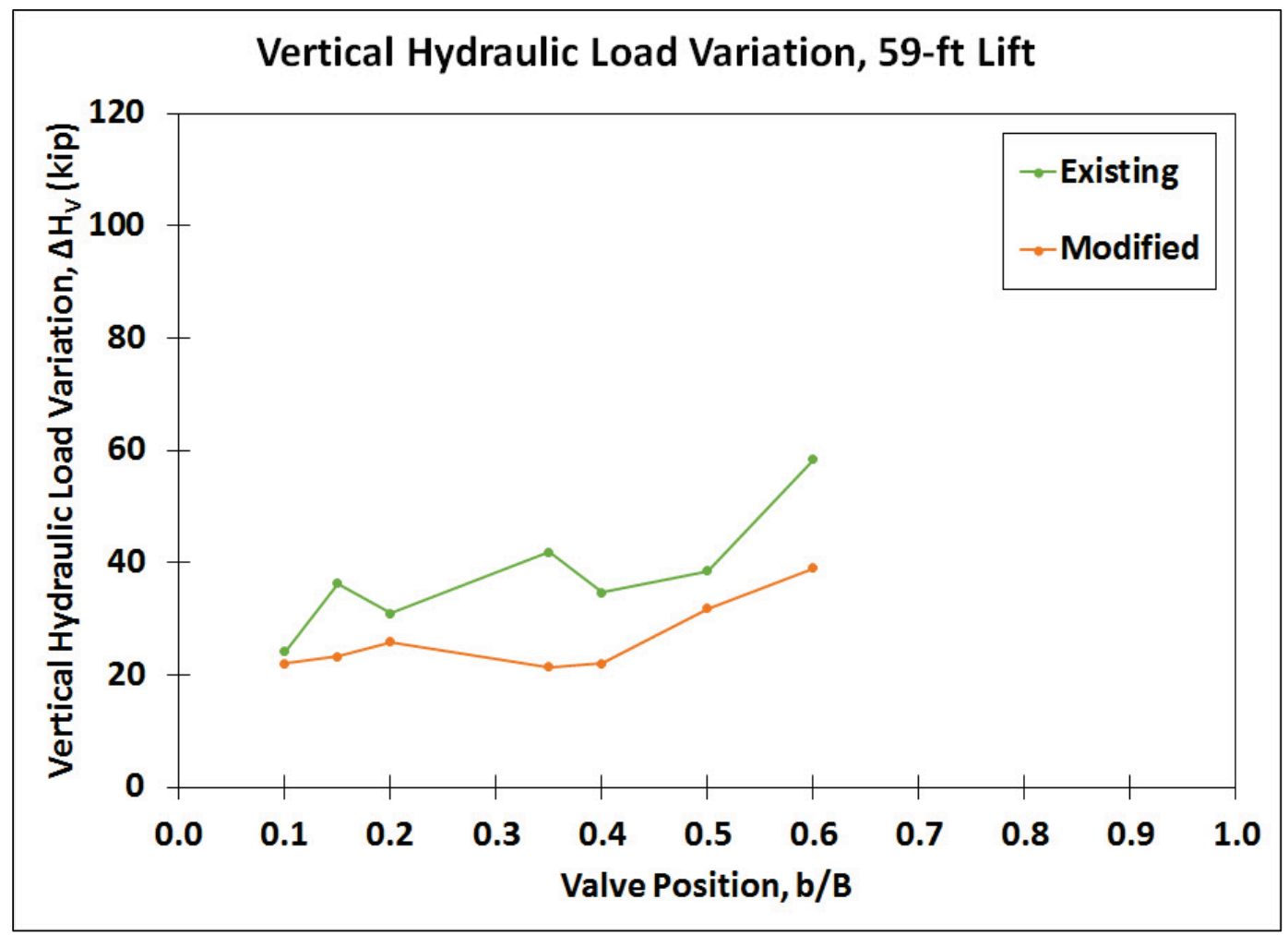

Figure 98. Longitudinal hydraulic load variation between valves $-51 \mathrm{ft} \mathrm{lift.}$

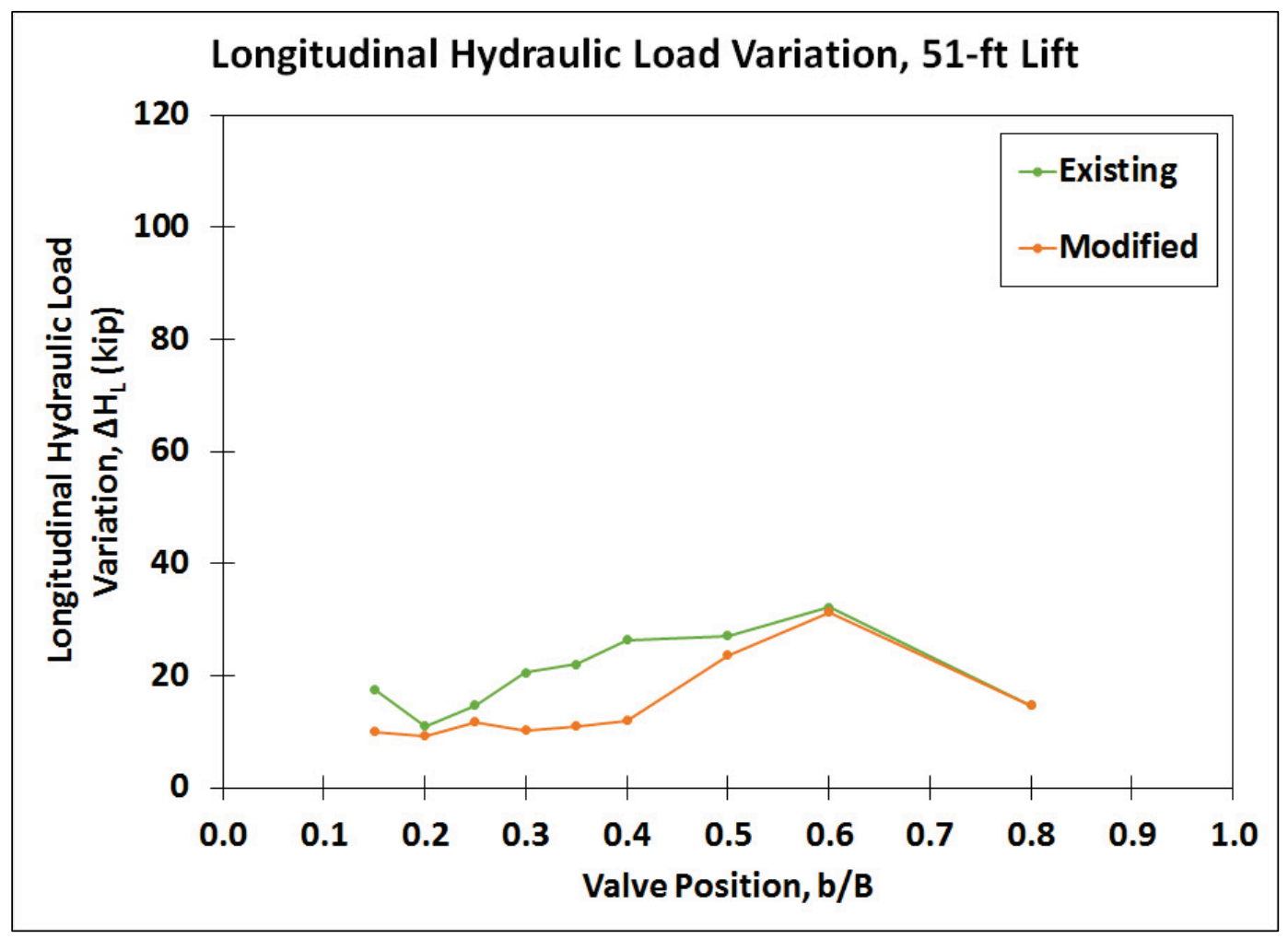


Figure 99. Longitudinal hydraulic load variation between valves $-59 \mathrm{ft}$ lift.

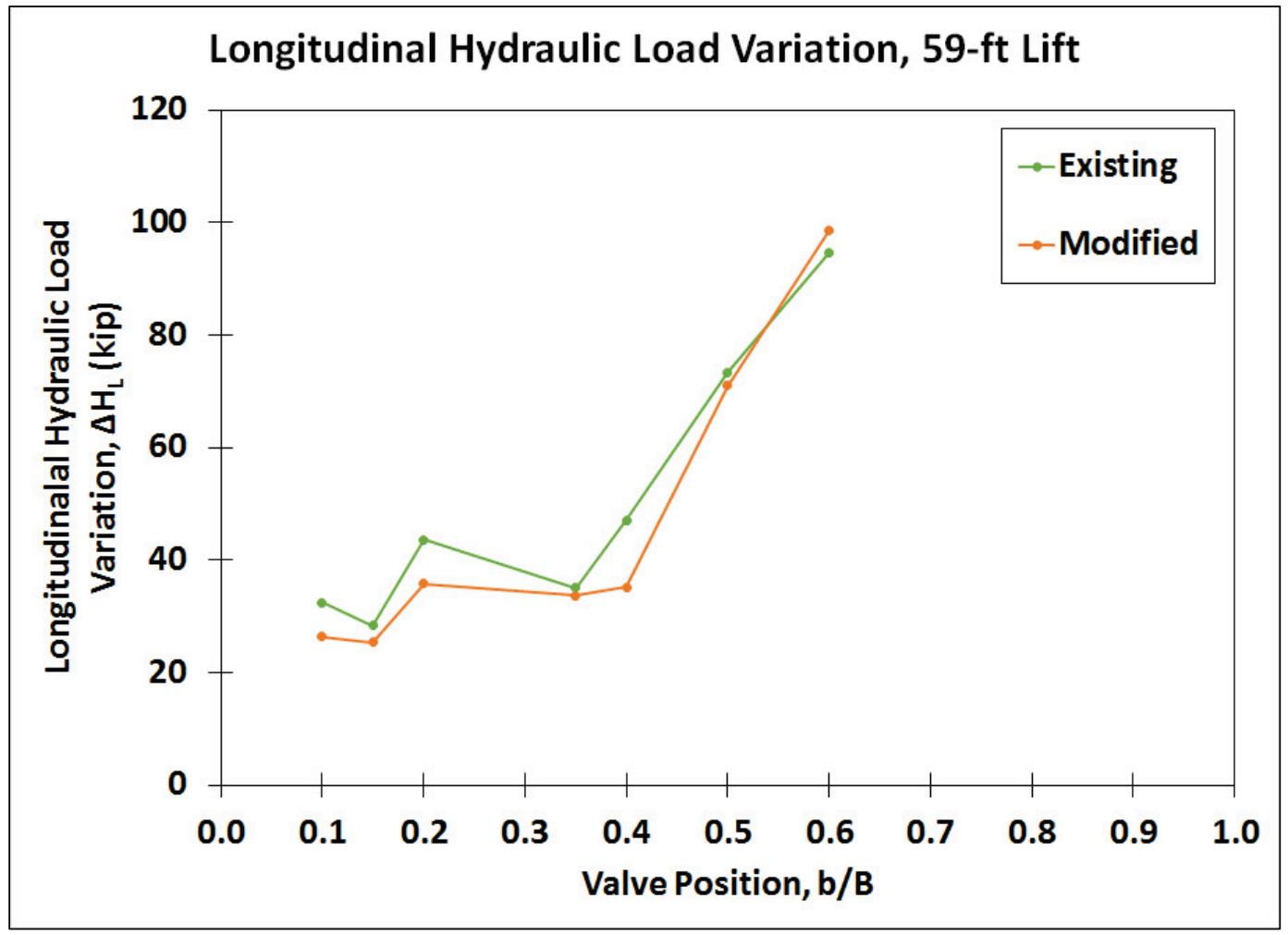

Figure 100. Resultant hydraulic load variation between valves $-51 \mathrm{ft}$ lift.

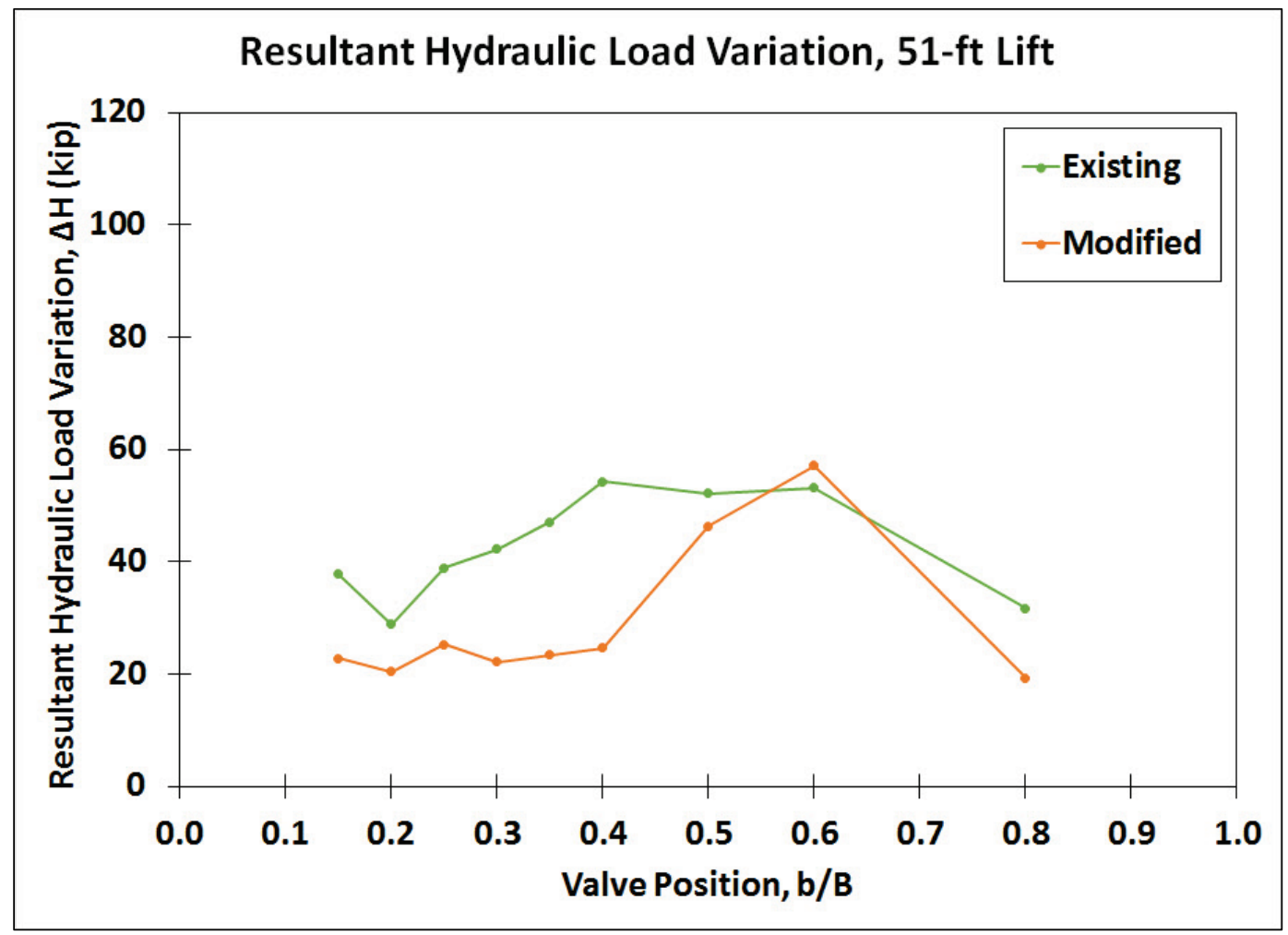


Figure 101. Resultant hydraulic load variation between valves $-59 \mathrm{ft} \mathrm{lift.}$

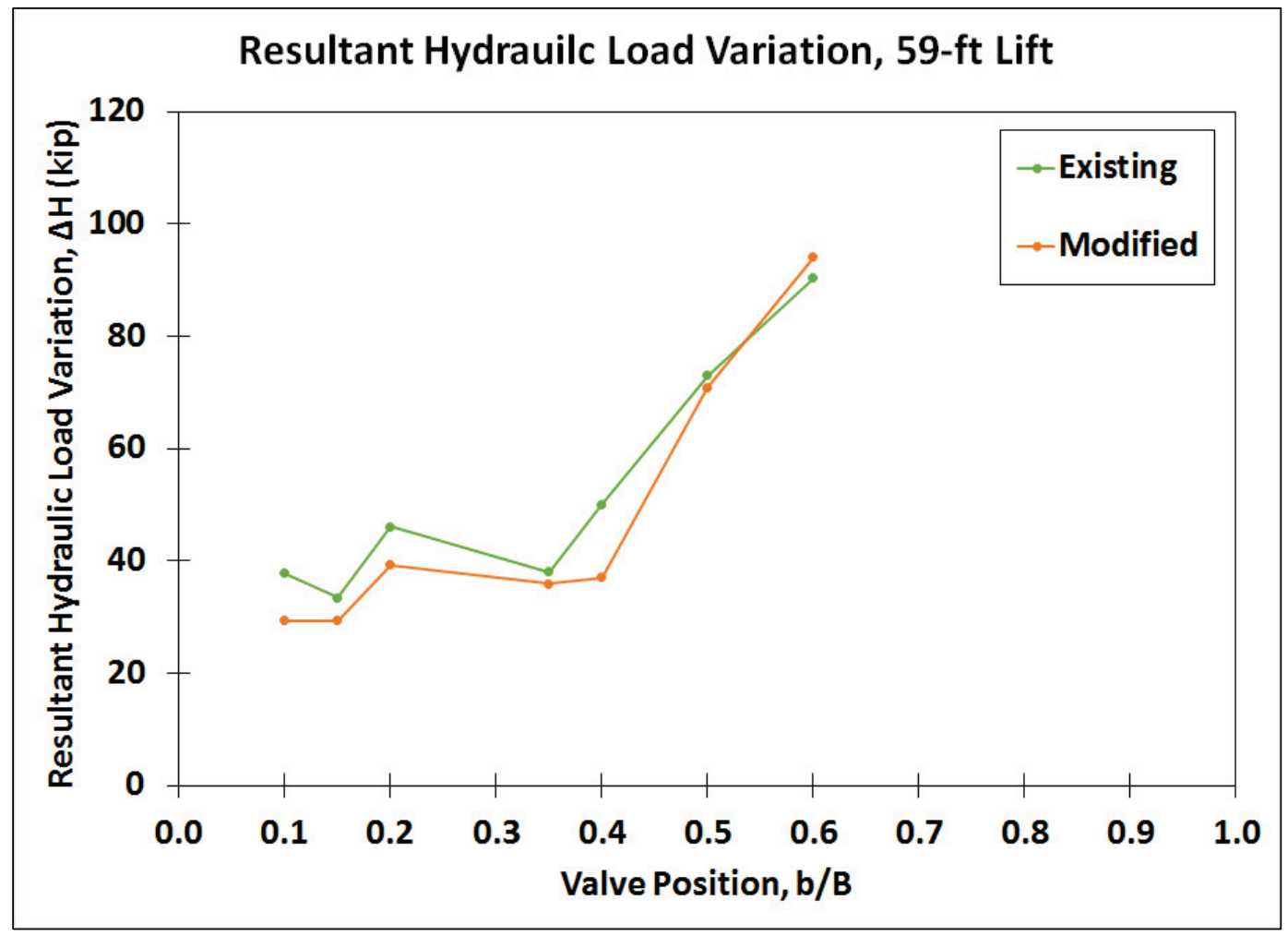




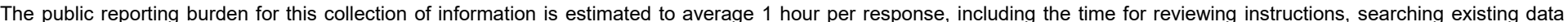

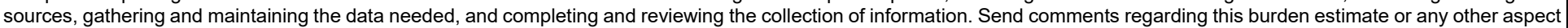

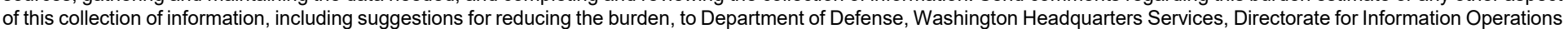

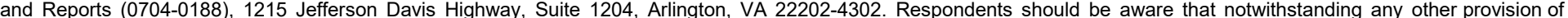
law, no person shall be subject to any penalty for failing to comply with a collection of information if it does not display a currently valid OMB control number. PLEASE DO NOT RETURN YOUR FORM TO THE ABOVE ADDRESS.

\begin{tabular}{l|l|l}
\hline $\begin{array}{l}\text { 1. REPORT DATE } \\
\text { May } 2019\end{array}$ & $\begin{array}{l}\text { 2. REPORT TYPE } \\
\text { Final Report }\end{array}$ & 3. DATES COVERED (FrOm - To)
\end{tabular}

\section{TITLE AND SUBTITLE}

Hydraulic Analysis of the Pickwick Lock Culvert Valves 5a. CONTRACT NUMBER

5b. GRANT NUMBER

5c. PROGRAM ELEMENT NUMBER

5d. PROJECT NUMBER

448755

5e. TASK NUMBER

5f. WORK UNIT NUMBER

8. PERFORMING ORGANIZATION REPORT NUMBER

ERDC/CHL TR-19-6

10. SPONSOR/MONITOR'S ACRONYM(S)

LRN

11. SPONSOR/MONITOR'S REPORT NUMBER(S)

\section{DISTRIBUTION/AVAILABILITY STATEMENT}

Approved for public release; distribution is unlimited.

\section{SUPPLEMENTARY NOTES}

\section{ABSTRACT}

The reverse tainter valves at Pickwick Lock on the Tennessee River are being replaced. The original valves have experienced excessive repairs during their service life, so a new valve design is sought. A hydraulic physical model study has been conducted to collect flow and load information on the existing lock culvert valve and a proposed valve design. The proposed valve geometry is based on experience gained from other model and prototype studies of lock culvert valves. The loads on the trunnion, the axial load on the strut connecting the valve lift mechanism to the valve, and pressures along the culvert have been measured for both the existing and proposed valve designs. Using the information gleaned from all test results, a final valve design recommendation is provided.

\section{SUBJECT TERMS}

Hydraulics, Hydraulic structures, Locks (Hydraulic engineering), Pickwick Dam (Tenn.), Pressure, Valves

\section{SECURITY CLASSIFICATION OF:}

\begin{tabular}{|l|c|l|l|}
\hline a. REPORT & b. ABSTRACT & c. THIS PAGE & \multirow{2}{*}{ ABSTRACT } \\
Unclassified & Unclassified & Unclassified & SAR \\
& & &
\end{tabular}

18. NUMBER OF PAGES

111 19a. NAME OF RESPONSIBLE PERSON

19b. TELEPHONE NUMBER (Include area code) 601-634-3628 